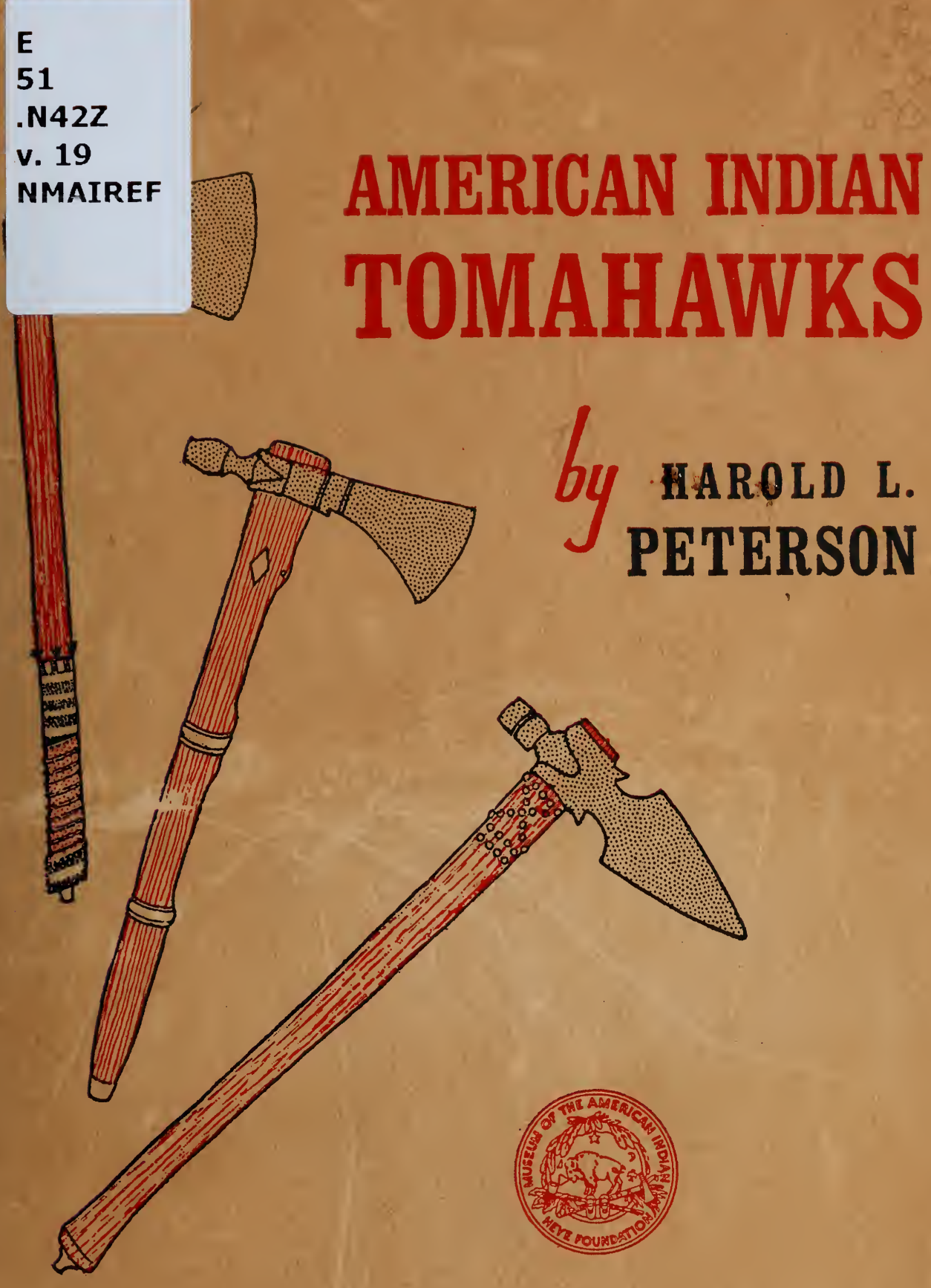

MUSEUM OF THE AMERICAN INDIAN HEYE FOUNDATION 1965

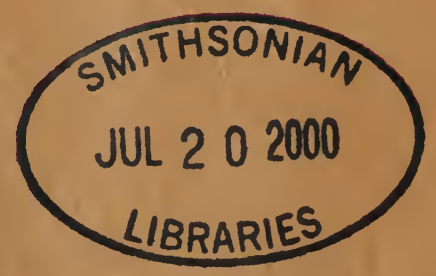


Dellon 
$e$
51

NMI2 


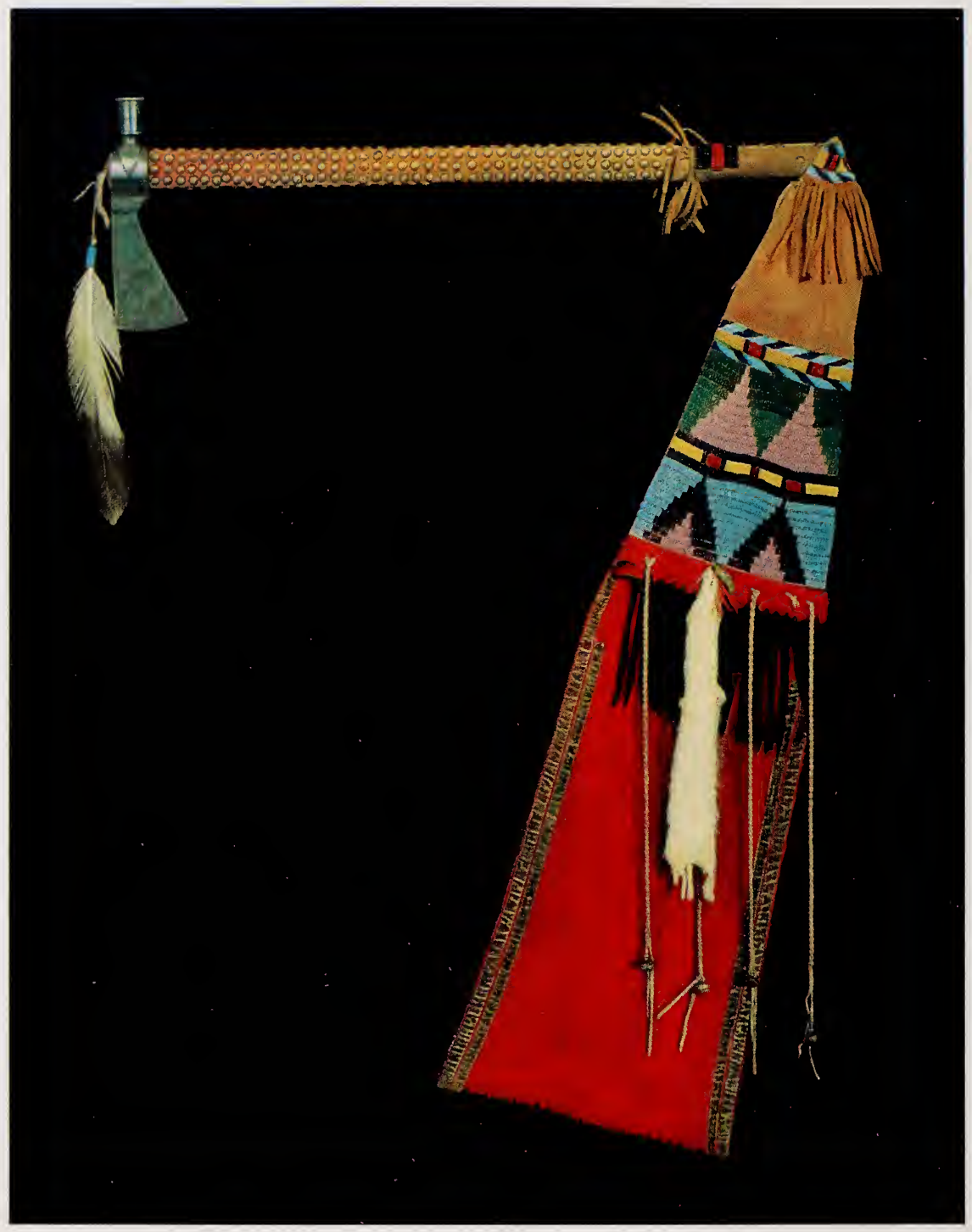

AN EXAMPLE OF A PIPE TOMAHAWK WITH EXTREMELY ELABORATE DECORATION (see No. I6I) 
CONTRIBUTIONS FROM THE

MUSEUM OF THE AMERICAN INDIAN

HEYE FOUNDATION

VOL. XIX

\title{
AMERICAN INDIAN TOMAHAWKS
}

\author{
by HAROLD L. PETERSON
}

With an Appendix:

THE BLACKSMITH SHOP

by MILFORD G. CHANDLER

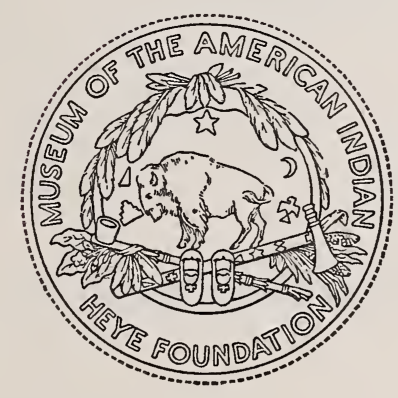

MUSEUM OF THE AMERICAN INDIAN HEYE FOUNDATION 
Library of Congress Catalogue card number 65-I 7277 Printed in Germany at J. J. Augustin, Glückstadt

Price: $\$ 8.50$ 


\section{CONTENTS}

ILLUSTRATIONS $\ldots \ldots \ldots \ldots \ldots \ldots \ldots \ldots \ldots \ldots \ldots \ldots \ldots$ iv

FOREWORD $\ldots \ldots \ldots \ldots \ldots \ldots \ldots \ldots \ldots \ldots \ldots \ldots \ldots \ldots$ vii

INTRODUCTION $\ldots \ldots \ldots \ldots \ldots \ldots \ldots \ldots \ldots \ldots \ldots \ldots \ldots \ldots \ldots$ I

CHAPTER

I. A Matter of Words .................... 4

II. The Indian and the Tomahawk $\ldots \ldots \ldots \ldots \ldots \ldots 8$

III. The Simple Hatchet or Belt Axe ............ I8

IV. The Missouri War Hatchet . . . . . . . . . . . 22

V. The Spontoon Tomahawk ................. 24

VI. The Halberd or "Battle Axe" Tomahawk ........ 27

VII. The Spiked Tomahawk $\ldots . \ldots \ldots \ldots \ldots \ldots . . \ldots 29$

VIII. Tomahawks with Hammer Polls ............ 3I

IX. Celtiform Tomahawks ................. 32

$\mathrm{X}$. The Pipe Tomahawk .................. 33

XI. The White Man and the Tomahawk $\ldots \ldots \ldots \ldots \ldots 40$

XII. Naval Boarding Axes $\ldots \ldots \ldots \ldots \ldots \ldots \ldots \ldots . . \ldots 4$

Directory of Makers and Dealers $\ldots \ldots \ldots \ldots \ldots \ldots .46$

Index to Provenience $\ldots \ldots \ldots \ldots \ldots \ldots \ldots \ldots \ldots \ldots \ldots \ldots$

APPENDIX:

"The Blacksmith's Shop," by Milford W. Chandler .... 55

Bibliography $\ldots \ldots \ldots \ldots \ldots \ldots \ldots \ldots \ldots \ldots \ldots \ldots \ldots \ldots \ldots \ldots \ldots \ldots$

Captions to Photographs ..................... 83 


\section{ILLUSTRATIONS}

\section{Plates}

I. Decorated Pipe Tomahawk .............. frontispiece

(following page 32)

II. Sketch of an Indian throwing a tomahawk.

III. Engraved powder horn.

IV. Sketches of mid-Igth century weapons, by Seth Eastman.

V. Page from Lewis and Clark's journal.

VI. Page from Lewis and Clark's journal.

VII. King Hendrick of the Mohawks.

VIII. Cornplanter, painted by Frederick Bartoli.

IX. Sa Ga Yeath Qua Pieth Ton, one of the "Four Kings."

$\mathrm{X}$. Indian with a spontoon axe.

XI. Woainga, or "Pipe-Stem," an Oto man.

XII. Chief Holds-His-Enemy, a Crow warrior.

XIII. Plug cutter for Battle Ax Plug Tobacco.

\section{Text Figures}

PAGE

I. Nomenclature of a hatchet $\ldots \ldots \ldots \ldots \ldots \ldots$ II

2. Manufacture of a simple belt axe $\ldots \ldots \ldots \ldots \ldots$ I9

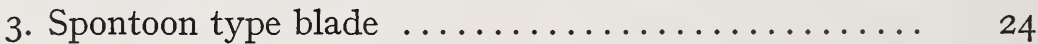

4. Halberd type blade $\ldots \ldots \ldots \ldots \ldots \ldots \ldots \ldots \ldots \ldots . \ldots \ldots$

5. Construction of a spiked hatchet $\ldots \ldots \ldots \ldots \ldots \ldots$

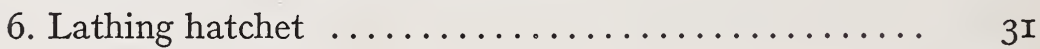

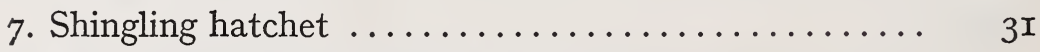

8. Method of forging a pipe tomahawk ........... 37

9. Tools and equipment used in making tomahawks .... 58-59

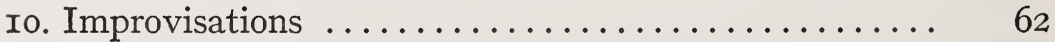

II. Improvisations $\ldots \ldots \ldots \ldots \ldots \ldots \ldots \ldots \ldots \ldots \ldots \ldots 6_{3}$

I2. Improvisations $\ldots \ldots \ldots \ldots \ldots \ldots \ldots \ldots \ldots \ldots \ldots$

I3. Manufacture of the common pipe tomahawk . . . . . 66-67

I4. Alterations on the common pipe tomahawk ...... 68

I5. The pierced eye technique of making a tomahawk ... 70-7I

I6. Manufacture of a gun-barrel tomahawk ........ 72 
I7. Manufacture of a pipe tomahawk using the "wraparound eye and blade" technique ........... 74-75

I8. An Indian's modification of a ball-peen hammer .....

\section{Photographs of Tomahawks}

(following page I42)

\begin{tabular}{|c|c|}
\hline Aboriginal Forms & $I-23$ \\
\hline Simple Hatchets and Belt Axes & $25-45$ \\
\hline Missouri War Hatchets & $46-5 I$ \\
\hline Spontoon Tomahawks ......... & $52-53$ \\
\hline Halberd Tomahawks .... & $54-60$ \\
\hline Spiked Tomahawks & $6 I-88$ \\
\hline Tomahawks with Hammer Polls & 89 -IOI \\
\hline Celtiform Tomahawks .......... & I02-I06 \\
\hline Pipe Tomahawks of the Halberd Form & I07-I08 \\
\hline Pipe Tomahawks with Conventional Blades: & \\
\hline Iron or Steel Heads ... & I09-208 \\
\hline Brass Heads with Steel Edges & 209-2I9 \\
\hline All-Brass Heads & $220-239$ \\
\hline Pewter or Lead Heads & $240-255$ \\
\hline Silver Heads & 256 \\
\hline Stone Heads & 257 \\
\hline
\end{tabular}

Pipe Tomahawks with Spontoon Blades:

Iron or Steel Heads $\ldots \ldots \ldots \ldots \ldots \ldots \ldots \ldots . \ldots \ldots$ 258-287

Brass Heads ... . . . . . . . . . . . . . . . . . . . . 288-293

Pewter Heads . . . . . . . . . . . . . . . . . . . 294-298

Stone Heads ......................... 299

Implements Used by White Men ............ 300-3I4 



\section{FOREWORD}

The pipe tomahawk is an implement unique in American Indian life. Although most native peoples of the world had cutting axes and smoking pipes, it was only in North America that these two functions were fused into a single object. Over a period of 250 years, it served on different occasions as a functioning tool, a ceremonial adjunct, a decorative object, and a symbol of prestige. And, above all, it has become romantically associated with the Indian as no other implement.

Yet with all of this historical and sociological lore, almost no serious attention has been given to the story of its development and typology, as the bibliography will attest; this volume represents an attempt to present much of that story in detail.

In selecting a suitable author, we turned to Harold L. Peterson, an outstanding authority on American colonial arms and armor, to supply for the first time a summary of the art of the blacksmith together with a history of the role of the tomahawk in Indian life.

To round out the more personal relationship of the blacksmith with his Indian customers, we asked Milford G. Chandler to recount experiences drawn from his early life in the Midwest. Mr. Chandler, who grew up in Indiana when it was still a part of the Frontier, saw smiths turn out tomahawks for the Indian trade. We are indebted to his son, Alan L. Chandler, for executing the drawings for the appendix.

Accompanying these accounts is certainly the most extensive visual record of tomahawk types yet published. Captions supply documentation as complete as has been possible to gather for each of the more than three hundred specimens illustrated, making this volume particularly useful as a reference work.

A word should be inserted concerning provenience. Wherever a given tomahawk has been obtained from a known person or tribe, the phrase, "collected from...," is employed. This is the most accurate statement which can be supplied to associate the object with its history. When a specimen comes to the Museum with an alleged history or statement of ownership through a third hand, the phrase, "attributed to...," implies that we accept at face value the asserted provenience, but cannot guarantee its accuracy beyond this hearsay and our own experience. 
Much of the study material is drawn from the collections of the Museum, gathered over the past half century. However, particular acknowledgement must be made to the Harold J. Hibben Collection, which forms such a significant part of this work. Mr. Hibben, of Indianapolis, Indiana, was an avid collector of tomahawks and, at his death in I956, owned some four hundred and fifty examples. These were generously presented to the Museum in I959 by his nephew, Mr. Richard M. Fairbanks, also of Indianapolis. They have been given catalog numbers 22/7I98 through 22/7408, so that all of the Hibben specimens used herein can be readily identified.

Our gratitude is extended to Mr. Fairbanks for the gift of the Hibben Collection without which this publication would not have been possible, and we acknowledge the assistance of Mr. Robert Beverly Hale of the Metropolitan Museum of Art for his friendly coöperation in our behalf. To Mr. Peterson go our thanks for his willingness to undertake this study, as well as for his patience during the long delay in its production; and to Miss Elaine Taylor for editing the manuscript.

November, I964

Frederick J. Dockstader Director 


\section{INTRODUCTION}

T HE metal trade tomahawk has long been an object of fascination for both the amateur collector and the ethnologist. Few other implements have ever combined so many different functions: tool, weapon, scepter, symbol and smoking pipe. In this one instrument is collected the lore of handicraft, warfare, prestige, ceremony and personal comfort. Because of this wide appeal, and because good specimens are scarce, prices have increased tremendously on the open market in recent years. This has led, in turn, to the manufacture of reproductions and even outright fakes. Yet, in spite of this very evident widespread interest, surprisingly little has been published on the tomahawk. Arthur Woodward's pioneering study, which appeared in the Bulletin of the Fort Ticonderoga Museum in I946, and a few short articles in more recent periodicals, constitute almost the entire specific literature of the subject. It is hoped that the present study will collate the data that have already been published in scattered sources with those gleaned from an intensive study of actual specimens into one handy reference for the use of future students in their efforts to carry the investigations still further.

As has been stated, the number of surviving tomahawks is comparatively small. It is a fortunate museum or collector with more than Ioo specimens, and the Museum of the American Indian with over 700 is in a class completely by itself. Yet almost every one of these tomahawks is different from every other. A few exact duplications are encountered, but they are the exception; usually, even these demonstrate variations or differences in the decoration or in the haft. Thus it has been necessary to choose only representative examples for illustration and description here. Of more than 2000 specimens studied by the writer during the past ten years, approximately 300 have been chosen as illustrating the principal types, or which display characteristic features, that will assist in identifying others which may differ somewhat in detail.

The dating of tomahawks is as yet by no means precise, for only a very few bear dates or makers' names. The balance must be dated approximately through provable historical associations, paintings or photographs, or the use of various materials which are in themselves datable. Much weight must be given to style and workmanship. This is a dangerous procedure, for manufacturers in 
certain areas tended to be more conservative than those in others, and one is apt to find a tomahawk made by an older or an isolated smith in a style that was no longer generally popular at the time of its manufacture. Thus the dates given herein are in most cases approximations based on the best collateral data available, and they represent the years of greatest popularity for each style.

No work such as this would be possible without the help of many unselfish people who have freely given of their time and knowledge and have allowed me full access to their collections. It would not be possible to mention all who have assisted, but it is imperative that special acknowledgment be given the following:

To Mr. E. K. Burnett, Dr. Frederick J. Dockstader and Mr. Charles Turbyfill of the Museum of the American Indian; Mr. Philip C. Gifford, Jr., of the American Museum of Natural History; Mr. Robert A. Elder, Mr. Edgar M. Howell and Mr. Craddock goins, Jr. of the Smithsonian Institution; Mrs. Eugenia Langford of the Interior Department Library; Mr. Donald A. Shelley and Mr. George Bird of the Henry Ford Museum; Mr. Patrick Patterson of the Woolaroc Museum; Col. Edward P. Hamilton and Miss Eleanor Murray of the Fort Ticonderoga Museum, all of whom have made the materials in their care freely available for study, have offered critical suggestions or provided other assistance far beyond the call of duty.

To Dr. Francis S. Ronalds and Charles Steen of the National Park Service, and Charles Hanson, former Director of the Museum of the Fur Trade, who have provided helpful documentary materials and suggestions.

To Ben F. Hubbell, LaDow Johnston, John and Mary duMont, Robert Abels, Ben Palmer, William O. Sweet, Gary L. Granger, T. M. Hamilton, Robert F. Wheeler, Clem Caldwell, Donald Baird, Herb Glass, Clay Fielden, and Joseph Kindig, Jr., advanced collectors all, who have freely loaned their pieces for study, and provided photographs or data without restriction.

To Dr. Carl P. Russell, who has generously permitted access to and use of his unpublished study on the materiel of the fur trade.

To Dr. Wilfred D. Logan of the National Park Service, who read and criticized the manuscript.

To Bluford W. Muir, who spent many hours photographing the specimens from private collections.

To Carmelo Guadagno, staff photographer of the Museum of the American Indian, for his patient coöperation in taking care of the requirements of a specialist in such painstaking fashion.

To Milford G. Chandler, for his courtesy in allowing the inclusion of his own observations as an Appendix to this study. 
And finally, to my wife, Dorothy, who typed the manuscript and helped in so many ways.

Harold L. Peterson,

Chief Curator

National Park Service

United States Department of the Interior

Arlington, Virginia, I964 


\section{CHAPTER I}

\section{A MATTER OF WORDS}

$\mathrm{N}$ AMES can confuse as well as clarify, and this is especially true of the tomahawk. For years students and writers, archeologists and collectors have been accustomed to using names for specific forms or general categories of hatchet or tomahawk. They refer to squaw axes, half axes, or to French, Spanish, Minnewauken, Woodlands, or English types with the calm assumption that these are accepted terms and will be understood. This is far from true. Many of these names have little or no validity in historical fact or usage but have been coined by a writer and based upon his own observations and deductions. Another writer in a different part of the country often independently adopts the same term for an entirely different pattern, and adds to the confusion. It is thus necessary to discuss and define the various technical terms and names that will be used in this study, as well as a few that will not be used. Generally speaking, when it is necessary to identify a category, a descriptive name based on obvious physical features will be used unless there is definite historical or ethnological reason for classifying it according to use or area of origin.

The very word tomahawk itself has a history of confusion. It derives from the Algonquian Indians of Virginia whose original words tamahak or tamahakan indicated a utensil for cutting. Other Algonquian groups had similar words, but it is the Lenape term which entered the English language through the settlers who founded Jamestown and encountered this group in I607. ${ }^{\mathbf{1}}$

The colonists were by no means linguists, and their faulty understanding of the Indian's usage of the term made their definitions inaccurate and has so clouded the issue that it is now impossible to be absolutely sure just which instrument or class of instruments an Algonquian speaker meant when he used the word.

1 William H. Holmes, "Tomahawk," in Frederick W. Hodge (ed.) "Handbook of American Indians North of Mexico," Bureau of American Ethnology Bulletin 30, 2 vols (Wash., D.C., I909, I9I0), II, 773-775. Arthur Woodward, "The Metal Tomahawk, Its Evolution and Distribution in North America," Bulletin of the Fort Ticonderoga Museum, VII, No. 3 (Jan. I946), 3. William R. Gerard, "The Term Tomahawk," American Anthropologist, X, No. 3 (I908), I77-I80. William H. Holmes, "The Tomahawk," ibid., X, No. 2 (I908), 264-276. 
Captain John Smith is believed to have been the first to bring the word into English in his brief vocabulary of Indian terms prepared sometime during the years r607-r6o9, when he defined tomahaks simply as meaning "axes." Later he added that the term was applied to both the native war club and the iron hatchet. ${ }^{2}$

Subsequent writers followed suit, applying the name impartially to the native celt hatchet, the grooved axe, the knobbed club, the falchion club, spiked club, gunstock club, and the iron trade axe and hatchet. Taken out of its context in an early document, the word thus means nothing; it could be any striking weapon or tool. Conversely, it is interesting to note that during the 18 th century iron hatchets are sometimes referred to as "war clubs" by contemporaries. ${ }^{3}$

As the years passed, the term tomaharek came to be applied strictly to metal hatchets. Any form of hatchet not specifically connected with a trade or profession, such as a coopering hatchet, shingler's hatchet, or the like, might receive the name, though there was always the implication that it was to be used as a weapon. During the I8th century this usage reached its height. Then the trend again changed. The term began to be restricted to hatchets possessed by Indians, and finally it was applied primarily to the pipe tomahawk, while other forms were designated simply as "hatchets," or sometimes "war axes," or "battle axes."

Through all of this period, the tomahawk might also be simply called a hatchet. This term, too, is interesting in its usage and implications. Normally it connotes a small form of the axe, designed to be wielded with one hand. Yet, during the I 7 th century, the weights given for hatchet heads to be traded to the Indians, (often two or three pounds each), indicate that they were sometimes of a size that would be considered an axe today. ${ }^{4}$

It is this size factor that also accounts for another term frequently encountered, the squaw axe (see No. 25). Some modern writers have a tendency to equate the squaw axe with all simple

2 Ibid. John Smith, "A Map of Virginia," Lyon Gardiner Tyler (ed.), Narratives of Early Virginia, I606-I625 (N. Y., I907), 78, I02, I03. Carl Russell, Material Things of the American Traders and Trappers, unpublished manuscript.

${ }^{3}$ Ibid. William Wood, New England's Prospects (I898), 62. "A Relation of Maryland, I635," Clayton C. Hall (ed.), Narratives of Early Maryland, I633-I684 (N.Y., I9I0), 86. William S. Fowler, "Tomahawks of Central New England," Bulletin of the Massachusetts Archeological Society, XII, No. 3 (Apr. I95I), 29-37, and "Trade Tomahawks," ibid., XIII, No. 3 (Apr. I952), 23-25.

${ }^{4}$ Harold A. Innis, The Fur Trade in Canada (New Haven, I930), I5. Carl Russell, $M S$. cit. 
hatchets and thus differentiate them from those having spikes, pipes or other attachments. There seems to be no historical justification for this usage, however, except that squaw axes were simple implements without spikes or pipes. The term is an old one, in use at least by I8o6, and it appears to have been used to designate the two- and three-pound hatchets mentioned above, when it became the custom to distinguish them from the lighter forms of the size normally associated with hatchets today. These smaller forms were suitable for use as a weapon and for light cutting. The larger ones were more useful for cutting wood and other utilitarian tasks normally performed by Indian women. Although such differentiation apparently began early in the 18 th century, it has as yet been impossible to document. ${ }^{5}$

A final general term occasionally encountered is the half axe or half hatchet. This derived from the era when axe blades frequently flared out symmetrically. In the half axe only the side toward the hand flared out. The other side was straight or curved slightly in the same direction. In the era considered here, the half axe was the normal form for hatchets and felling axes, and the term itself was becoming obsolete. ${ }^{6}$

In this present volume, only metal trade tomahawks will be considered in detail, and the broadest definition of these will be used to cover all of the forms normally traded to Indians or used by Caucasians and called by that name. For purposes of classification, these will be divided into types according to their distinguishing physical characteristics, then subdivided by chronological period, and the materials of which they are made.

For all hatchets and axes there are certain technical terms which make description easier, and these, too, must be tightly defined to prevent confusion (see Fig. I). The piece is normally described as seen in a horizontal position with the head to the viewer's right, blade down. The side toward the viewer is then the obverse; the far side is the reverse. There are two principal parts of every complete hatchet: the haft (which is also called the handle or helve) and the head. The head consists of the blade or bit, the eye (the hole through which the haft passes), and the poll (technically, the thickened portion of the head on top of the eye and opposite the blade, but usually applied to the top of the eye whether it is thickened or not). The blade itself is sharpened to an edge for cutting, and has two main features: the corner nearest the hand, called the heel, and the far corner, called the leading edge. Sometimes

5 Sir William Craigie and James R. Hulbert (eds.), A Dictionary of American English, 4 vols. (Chicago, I944), IV, 2210. Woodward, op. cit., 6.

${ }^{6}$ Woodward, $o p$. cit., 9. 
there are also projections of the head along the haft on either side of the eye. These are called ears and serve to strengthen the joint. In some specimens there is a metal plate or cap attached to the haft in front of the head, often helping to secure the head in position. This is called a fore-end cap, or plate, as the case may be.

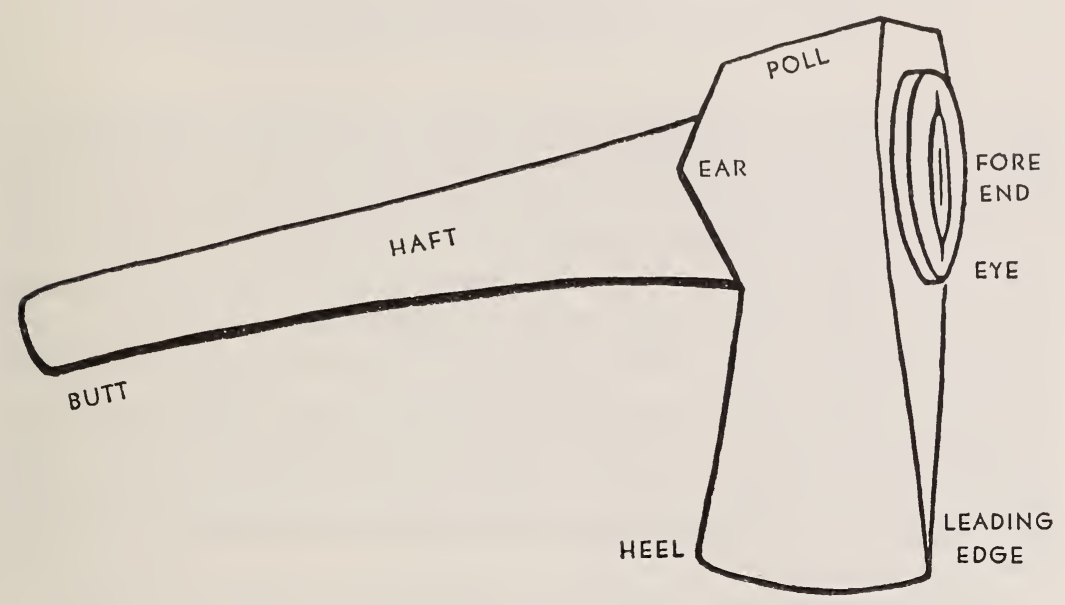

FIGURE I. Nomenclature of a hatchet.

In addition to these technical features, three terms will be used for dimensions: length, height, and width, abbreviated as $L$., $H$., and $W$. Length applies to those tomahawks with hafts, and is taken from the forward end of the haft to the tip of the butt or mouthpiece (if the specimen is a pipe tomahawk). Height refers to the vertical dimension of the head. It is taken in a straight line from a point equal to the tip of the spike, the top of the pipe bowl or the top of the poll depending upon the type of axe, to the lowest projection of the blade. The width refers specifically to the blade and is measured at its widest point (in spontoon blades, the curling arms are ignored and only the blade proper is considered). There are other minor features, but these are the essential ones for the discussion which follows. 


\title{
CHAPTER II
}

\section{THE INDIAN AND THE TOMAHAWK}

\begin{abstract}
A
LMOST from the moment the Indian first saw the metal hatchet or tomahawk he coveted it, and sought to possess one for himself. The efficiency of the new implement was readily apparent: it was deadlier in combat, more efficient in cutting wood, and just as useful as a ceremonial object. Although it was an excellent weapon, the white man was not as reluctant to trade it as he was to dispense guns. The axe was also self-sufficient; it could function without such components as powder and ball that had to be obtained from the traders. Thus the hatchet could and did spread rapidly through Indian trade routes far from the points of white contact, reaching tribes and areas as yet unknown to the
\end{abstract} few Europeans along the coast.

As it was absorbed, the single tomahawk or hatchet replaced a number of more primitive specialized implements. It has already been noted that the early colonial writers displayed a distressing lack of accuracy in their description and identification of Indian weapons and tools. Even when descriptions were essayed, they were normally so vague that it is difficult if not impossible to obtain an accurate mental image of the piece in question.

Through the reading of numerous contemporary comments made over a period of a hundred and fifty years, however, a pattern does seem to appear. There were probably at least four and possibly five major types of clubs used as weapons in the eastern part of the United States when the colonists arrived. Of these, two principal categories were most often designated as tomahawksthe ball-headed club and the celt (see Nos. I-IO). This may not have been what was intended by the Algonquians, from whom the word came, but nevertheless it would seem to be the finally accepted English meaning and in this sense establishes them as the direct antecedents of the metal tomahawk. Thus one finds William Wood stating in I634, "Tomahawks be staves of two foote and a halfe long and a knob at one end as round and bigge as a football."' Needless to say, this was not the size of the modern football. A century later, Mark Catesby summed up the situation thus:

\footnotetext{
7 Wood, op. cit., 62.
} 
These [tomahawks] were of two kinds: one was a staff about three feet long, with a large knob at the end; the others were made of stone ground to an edge, of the form and size of a small hatchet, and fixed to a strong handle; these would cut, and were of much use, as well for war as for hollowing their canoes, and other mechanick uses; with these they fought and worked, but since the introduction of iron hatchets, which they still call tommahawks, they have wholly laid aside their stone ones. ${ }^{8}$

Although Catesby was essentially correct in stating that the celt as a tool had been superseded, it should not be assumed that the club as a weapon or ceremonial symbol had also become obsolete. The ball-headed club continued in use as a weapon through the early I9th century, often with the addition of an iron point set in the ball. Some time between I746-I755, Sir William Johnson had been given such a tomahawk club (see No. 3), and small decadent forms for ceremonial use have been made until very recent times. Other clubs, such as the gunstock club and the stone-headed warclub of the Plains tribes also continued in use as weapons through the middle of the Igth century. For examples, see Plates III and IV. 9

The first contact of the Indian with the iron or steel axe undoubtedly occurred with the arrival of the Vikings, and to judge from accounts in the sagas, the meetings were not auspicious. Two instances are recounted which may well be the first recorded encounters of the Indian with the weapon which later was to become almost synonymous with his warfare. The Saga of Eric the Red recalls the first reported battle of the Vikings with the natives of America, following which

8 Mark Catesby, The Natural History of Carolina, Florida, and the Bahama Islands, 2 vols. (London, I73I-I743), II, ix. See also: Holmes, loc. cit.; Fowler, loc. cit.; Hodge, loc. cit.; Harold E. Driver and William C. Massey, "Comparative Studies of North American Indians," Transactions of the American Philosophical Society, n.s. XLVII, Part 2 (Phil., I957), 357; John R. Swanton, "The Indians of the Southeastern United States," Bureau of American Ethnology Bulletin I37 (Wash., D.C., I946), 566570 .

${ }^{9}$ Driver and Massey, loc. cit. Swanton, loc. cit. Henry R. Schoolcraft, Historical and Statistical Information Respecting the History, Condition and Prospects of the Indian Tribes of the United States, 6 vols. (Phil, I85I-I857), II, plates 73, 74. John C. Ewers, "The Horse in Blackfoot Indian Culture," Bureau of American Ethnology Bulletin I59 (Wash., D.C., I955), 200, 20I, 202, 326, 330. Thomas L. McKenny and James Hall, The Indian Tribes of North America, 3 vols, (Edinburgh, I933, I934) passim. Louis Schellbach, "An Historic Iroquois Warclub," Indian Notes, V, No. 2, (Apr. I928) I58-166. George Catlin, North American Indians, 2 vols., (Edinburgh, I926), I, 266. 
The Skrellings [Indians], moreover, found a dead man, and an axe lay beside him. One of their number picked up the axe and struck at a tree with it, and one after another [they tested it] and it seemed to them to be a treasure, and to cut well; then one of their number seized it, and hewed at a stone with it so that the axe broke, whereat they concluded that it could be of no use, since it would not withstand stone, and they cast it away. ${ }^{10}$

\section{In another instance}

One of the Skrellings picked up an axe, and having looked at it for a time, he brandished it about one of his companions, and hewed at him, and on the instant the man fell dead. Thereupon the big. man seized the axe, and after examining it a moment, he hurled it as far as he could out into the sea.11

Following the visits of the Vikings, the Indian was cut off from a source of iron axes for some 500 years. Then came the explorers sailing along the coasts and pushing inland, and the fishermen harvesting the Grand Banks who also stopped along the shore to trade for furs. Axes came with them; the Indian quickly accepted them and sought them in trade well before permanent colonies were established. The French were the leaders in this sort of trade during the early years. Jacques Cartier is known to have distributed a gift of hatchets to the Micmac and Saguenay in I535, and both he and Verrazano had undoubtedly done so on earlier voyages without leaving records of the fact. Special trading voyages were made, and by the end of the century there was an official trading post, probably America's first, set up at Tadoussac on the Saguenay River. Champlain and the Sieur de Monts fostered the trade along the northern Atlantic coast and down the St. Lawrence River. ${ }^{12}$

From these contacts axes spread out through Indian middlemen in ever-widening circles. When John Smith explored Chesapeake Bay in I608, he found iron axes that had come down Indian trade routes from the French in Canada. From the Great Lakes area the Hurons braved the enmity of the Iroquois to obtain axes and other trade goods. When the Hurons and the Ottawas were driven westward after I663, they took their axes with them on across the

10 "The Saga of Eric the Red, also called The Saga of Thorfinn Karlsefni," in John E. Olson (ed.), The Northmen, Columbus and Cabot, 985-I 503, (N.Y., I906), 39.

11 "The Vinland History of the Flat Island Book," ibid., 6I, 62.

12 Jacques Cartier, The Voyages of Jacques Cartier, H. P. Biggar (ed.), (Ottawa, I924), 53, 60, I21, 125, 233. Samuel de Champlain, The Voyages of Samuel de Champlain, I604-I6I8, W. L. Grant (ed.), (N.Y., I907), passim. Carl Russell, $M S$. cit. William M. Beauchamp, "Metallic Implements of the New York Indians," New York State Museum Bulletin 55 (I9O2), 6-20, 59-65. 
Mississippi into the land of the Sioux and northward along Lake Superior to the Cree. These peoples had not known the axe, and in turn entreated the newcomers to obtain some for them. Thus, from the French posts alone, the iron axe had spread south as far as the Chesapeake and west along the St. Lawrence, around the Great Lakes and even across the Mississippi. ${ }^{13}$

But the French were not alone. In the early years of the I7 th century, the Dutch and Swedes traded up the Hudson and Delaware Rivers and along the coast from Connecticut to Delaware. The English began operations in Virginia and New England, and in 1668 the Hudson's Bay Company launched its extensive operations. In Florida and the Southwest, the Spanish had introduced the axe at an even earlier date. The pattern of Spanish relations with the Indians was different, with an emphasis on missions and agriculture, and the relative scarcity of marketable furs did not encourage a highly developed trade relationship for the distribution of goods such as axes. Furthermore, in the Southwest the cultural pattern of the Indian was different; the scarcity of timber and his methods of fighting, which did not involve the hatchet, made such implements of little interest to him. Thus, comparatively few axes found their way into Indian hands so that the over-all distribution from Spanish sources was limited.

Based partly upon source of supply and partly on needs and customs, the distribution of axes and tomahawks can be divided into certain relatively well-defined zones. The area of greatest concentration was the Northeast, comprising the New England and Middle Atlantic states, plus Michigan, Illinois, and Ohio. The Mohawk River Valley and western New York State formed the center, with probably the heaviest concentration of axes, hatchets and tomahawks of all descriptions to be found any place in the United States. In some parts of this area recoveries of early axes have been so heavy that for a time they were used as a cash crop by farmers who regularly "mined" them and sold the iron. ${ }^{14}$

The reasons for this concentration of axes in the Northeast are easily found. There were many sources of supply immediately at hand, with French, Dutch, and English traders all active. The relative density of Indian population insured a large potential market. And, finally, the wooded nature of the country and the customs of the various people, who placed great value on clubs and

13 John Smith, "Proceedings of the English Colony," Lyon Gardiner Tyler (ed.), Narratives of Early Virginia, I606-I625 (N.Y., I907), I49. Beauchamp, loc. cit. Innis, op. cit., 4I, 42.

14 Letter from Willis Barshied, Palatine Bridge, N.Y., to the author, Jan., 1960. Beauchamp, op. cit., 60. 
tomahawks both as symbols and as weapons. Because of the position they held in the culture of these peoples, the hatchets and tomahawks from this area are primarily functional tools and weapons; the ceremonial role did not outweigh utility until after the Indians of this region had been pacified and settled on reservations.

Further south, the concentration of tomahawks becomes less dense. The customs and needs of the Indians in the Southeastern United States were similar to those in New England and along the southern shores of the Great Lakes, but there were fewer sources of supply. The French operated along the Mississippi, especially in Louisiana, but not on the same scale as along the St. Lawrence. The Spanish in Florida were extremely conservative in their dealings, especially since their Indians did not have the fur resources of their northern brethren for exchange. The English had most of the rest of the area to themselves.

To the west, the tribes of the Plains and the Rocky Mountains sought the hatchet, and an area of concentration developed second in importance to the Northeast, but with one decided difference: the period of the concentration was later, and there was a distinct differentiation between the hatchet or tomahawk as a tool and as a ceremonial object. The old-time, double-pointed stone war club, on its long supple handle, suited the mounted combat of the area exceptionally well, and the tomahawk never held the same importance as a weapon among these people as it had in the East, although it was used occasionally in the Igth century. Thus there was an increasing emphasis on showy but inefficient specimens, finally reaching a stage of decadence where all resemblance to either tool or weapon had vanished, except for a vague similarity in general outline.

The Far West, except for the Northwest Coast, apparently had a lower concentration even than the Southeast, and the Southwest had almost none except for a few tools. The nature of the country, the customs of the people, and the Spanish attitude towards trade all combined to keep this area barren. Except for a few simple hatchets used as tools, such tomahawks as are found there seem usually to have been brought in by Indians migrating from the Plains area. Along the Northwest Coast there is again a higher concentration of tomahawks because of the wooded nature of the country and early white contact, but it still cannot compare with the Northeast where the contact was greater.

From this it will be seen that the primary impact of the metal hatchet and tomahawks upon Indian culture occurred in the Northeast and Southern Great Lakes area during the I7th and 
I8 th centuries. Lists of trade goods and treaty gifts indicate that the axe, hatchet, or tomahawk were among the most desired objects. As many as 300 axes might be handed out at one treaty meeting, and Sir William Johnson estimated that the Northern Indian Department needed I0,000 axes for trade purposes in the year I765 alone. Even if this should be taken as an exceptional year, operations such as this over a 200-year period by the French, Dutch, and English undoubtedly poured many hundreds of thousands of axes of all sorts into this area. ${ }^{\mathbf{1 5}}$

In the contemporary documents and narratives which mention the trade, the terms axe, hatchet, and tomahawk are frequently used almost interchangeably. Even so, it is possible to establish a general evolution of types. The first hatchets distributed during the I7th century were large affairs, with heads weighing two and three pounds. Gradually smaller types became more popular for carrying on hunting or war parties, and the larger specimens were left in the villages. All of these were smaller copies of the typical European felling axe, and will be discussed in detail in the section on simple hatchets and belt axes in Chapter III.

About I700, specialized forms began to appear which were still called axes, hatchets, or tomahawks at the time, but which are normally called tomahawks today. First came those with auxiliary spikes, then almost immediately those combined with pipes. All were large, strong implements, useful as a tool, a weapon, or as a ceremonial implement. It was about this time that other specialized forms developed, each of which will be considered in greater detail in another chapter. Later years saw the decline of the weapon: softer metals replaced the iron and steel, hafts were reduced in diameter, blades were made thinner, and all semblance of an edge disappeared. Finally came the copying of the form in stone (e.g., catlinite and slate), and wood, which could serve no useful purpose. Throughout this period the standard simple hatchet remained popular both as a tool and weapon, but it underwent much the same evolution as did the standard felling axe, albeit more slowly.

With his acceptance of the iron hatchet, and the consequent abandonment of native stone axes and clubs, the Indian became more dependent upon the white. Normally he did not have either the facilities or the skill to repair or replace the iron hatchet when it broke or wore out. Thus there were constant demands for blacksmiths to live with the Indians to care for their new hatchets and repair their guns and other metal implements. Young men who could learn the language were sought out and sent to the

${ }_{15}$ Woodward, op. cit., 9. Beauchamp, op. cit., 59-65. Carl Russell, MS. cit. 
Indians. There they became interpreters for colonial officers and formed a spy network which could dispatch word of impending trouble or dissent. This was an important factor in keeping the Indians under control during the I8th century as the British and French struggled for mastery of the continent with the help of their native allies. ${ }^{16}$

The potentialities of the axe as a weapon were apparent to the Indian from the outset. Garcilaso de la Vega tells of a bloody fight between an Indian armed with a captured battle axe and several of De Soto's soldiers, in which he even includes a I6 th century version of the old story of a man being cut in two so quickly by a keen blade that he remains standing and has time to pronounce a benediction before falling. In Florida, Jacques LeMoyne illustrated the murder of a colonist by an Indian with an axe during the brief French settlement at Fort Caroline, I564-1565. By the early I7 th century the tomahawk was firmly established in the minds of the white settlers as the Indians' primary weapon, and was much more feared than the bow and arrow. Even after the Indians had obtained a sizeable number of firearms, the tomahawk retained its popularity and importance. Once a gun had been fired, it was useless until it could be reloaded; an edged weapon was needed as a supplement, and this was the tomahawk. Moreover, for surprise attacks and raids, a firearm was frequently out of the question. And even though a knife was available, the Indian found the tomahawk more efficient, particularly in the style of warfare prevalent in the East during the I7 th and 18 th centuries. ${ }^{17}$

In the Igth century West, the tomahawk was less important as a weapon. Customs of warfare were different, and often involved the horse. Even so, tomahawks were used, as evidenced by an account related by the trapper, Osborne Russell, who tells of being attacked by Indians with upraised "battle axes" in the late I830's. The missionary, Marcus Whitman, was killed by a Cayuse warrior with a tomahawk at Waillatpu in I847, and there are skulls in the Army Medical Museum bearing tomahawk wounds which were collected as late as I869.18

16 Beauchamp, op. cit., 62-64. Woodward, op. cit., 6-9. Edmund B. O'Callaghan and others (eds.), Documents Relative to the Colonial History of New York, I 5 vols. (Albany, I853-I887), III, 775, 844; IV, 23, 43; IX, 8I6.

${ }^{17}$ Garcilaso de la Vega, The Flovida of the Inca, John G. and Jeanette J. Varner (eds.), (Austin, Tex., I95I), 46I-463. Stefan Lorant, The New World (N.Y., I946), II9.

18 Osborne Russell, Journal of a Trapper (Portland, Ore., 1955), I02. Ewers, op. cit., passim. The tomahawk supposedly used to mortally wound Whitman is now in the Oregon Historical Society Museum, Cat. No. 1607 . 
Normally the tomahawk was used in much the same manner as a club, but it could also be thrown to reach a foe at some distance. Hurling a hatchet so that it will strike blade foremost requires considerable skill; the thrower has to know how many times the implement will turn end-over-end in a given distance and be able to estimate the range between himself and his target accurately and swiftly. Should he miss, he would be disarmed and then might find himself the hunted, instead of the armed hunter. Nevertheless there seems to be ample evidence that the Indian could and did throw his tomahawk. In the I750's, Henry Timberlake reported "Neither are the Indians less expert at throwing it [the tomahawk] than using it near, but will kill at a considerable distance." 19 In I776, Ebenezer Elmer visited the Six Nations and noted that "they have the art of directing and regulating its motion, so that though it turns round as it flies, the edge always sticks in the tree near the place they aim at." 20 And the indefatigable traveler, Thomas Anburey, reported in I777 that in pursuing an enemy the Indians threw their tomahawks with the utmost dexterity and seldom failed "striking it into the skull or back of those they pursue ..."21 Much later, and farther west, George Catlin spoke of the tomahawk as being thrown "with unerring and deadly aim."22 It has been stated that this accuracy was acquired through the custom of throwing at small trees as a camp pastime, and Elmer's comment would seem to support this. It was also supposedly the custom occasionally, following a war speech in council, for all the assembled warriors to throw their hatchets high into the air, catching them by the hafts as they came down, while uttering shouts of approval. For pictorial evidence, by an Indian artist, of this practice, see Plate II. ${ }^{23}$

Because of its importance and constant use as a weapon, the tomahawk became a symbol for war, and for war potential. Many of the eastern tribes employed it as a metaphor in speeches and ceremonies, and sent either actual axes, or wampum belts which bore such a woven design, when war was under discussion, or when peace was concluded. For example, when peace was concluded in I670 following the defeat of the Algonquians by the Iroquois, a

${ }^{19}$ Lt. Henry Timberlake, Lieut. Henry Timberlake's Memoirs, I756I765, Samuel Cole Williams (ed.), (Johnson City, Tenn., I927), 77, 78.

${ }^{20}$ Ebenezer Elmer, "Journal Kept During an Expedition to Canada in I776," New Jersey Historical Society Proceedings, II (1847), I57, I 58.

21 Thomas Anburey, Travels Through the Interior Parts of America, 2 vols, (London, I79I), I, 356.

${ }^{22}$ Catlin, op. cit., I, 266.

${ }^{23}$ Woodward, op. cit., I4. Lewis Morgan, The League of the Iroquois, 2 vols. (N.Y. I922), II, I5. 
council was held during which six tomahawks were buried-one for each of the Five Nations, and one representing the defeated tribe. The Algonquian weapon was buried first, and the others were then placed on top of it, so that if hostilities were resumed, the Algonquian warriors would have to raise the weapons of their foes from their own, and thus be reminded of their defeat. As a token of condolence and peace, the vanquished tribe was given a wampum belt of purple beads, with a tomahawk design worked in white, and smeared with vermilion paint to "scare war" (see No. 24). As late as I83I, the Sauk leader, Black Hawk, sent a miniature wooden tomahawk smeared with vermilion paint to the Chippewa as an invitation to join him in war. Phrases developed using this metaphor, and some are still used as common figures of speech today. A belligerent statement was said to be a"tomahawk speech," while to "take up the hatchet" was to declare war; and as it still does today, to "bury the hatchet" meant to conclude peace, and there were many others, the meanings of which are less obvious. ${ }^{24}$

Another function of the tomahawk was the execution of Indians who had committed crimes against their own people. John Heckewelder cites such an instance in the execution of Leatherlips, a chief of the Wyandots, who had offended a faction of his tribe. When it was decreed that he must die, a piece of bark bearing a crude drawing of a hatchet was handed to the old man as a death warrant. Although he protested the decision, he submitted gravely, sitting down, placing his hand upon his knee and supporting his head on his hand. While he was in this position, one of the young Indians selected to carry out the sentence came up behind him and struck him twice with the tomahawk. In another instance, Mamachtaga, a Delaware convicted of murder and sentenced to death by a white frontier court in the late 18 th century, asked that he be tomahawked after the custom of his people, but was refused. ${ }^{25}$

Evidence that the tomahawk was used in the ritualistic torture of prisoners is presented by many tales of beatings with axes and dismemberments. From a very early period comes a picture of the death of the Jesuit missionaries Brébeuf and Lalemant at the hands of the Iroquois in I649, which shows several of the simple hatchets of the period being heated in a fire while a necklace of red-hot axe heads already hangs around the neck of Brébeuf. It is true that this picture was made in France, but it was done within

24 Joseph Keppler, "The Peace Tomahawk Algonkian Wampun," Indian Notes, VI, No. 2 (Apr. I929), I30-I38. Schoolcraft, op. cit., VI, $44^{8}$. Beauchamp, op. cit., 61, 62. Woodward, op. cit., I4-I6.

25 Beauchamp, op. cit., 6r. Woodward, op. cit., I7. 
a few years after the event depicted, and is presumed to have been based upon accurate information obtained from Jesuit writers of the period. ${ }^{26}$

Specially made "presentation tomahawks" were bestowed as gifts to important chiefs to solemnize treaties and help ensure their friendship. These were frequently elaborate affairs with inlays of silver in both blade and haft, engraved decorations, and sometimes bore presentation inscriptions. Such objects were highly prized by their recipients and were often handed down from generation to generation as part of the regalia of leadership. In I860, Benson J. Lossing found Chief G. H. M. Johnson of the Six Nations carrying a presentation tomahawk of the 18 th century as part of his insignia of authority. ${ }^{27}$

The addition of the pipe bowl to the hatchet blade about I700 allowed the Indian to add his ceremonial tobacco rites to these other uses of the hatchet, so that it became indeed almost indispensable. It was usually carried thrust through the belt on the right side, or in the back with the head to the right. As has been noted, it was this symbolic and ceremonial function that eventually became paramount and allowed the pipe tomahawk to survive into the present century long after it had outlived its utilitarian purposes. ${ }^{28}$

${ }^{26}$ Francisco Creuxiux, Historiae Canadensis sen Novae Franciae (Paris, I664). C. W. Jeffreys, The Picture Gallery of Canadian History, 3 vols. (Toronto, I945-1952), I, I06.

${ }^{27}$ Benson J. Lossing, The Pictorial Field-book of the War of I8I2 (N.Y., I869), 421. Woodward, op. cit., 25-27.

${ }_{28}$ Joseph D. McGuire, "Pipes and Smoking Customs of the American Aborigines," Annual Report of the U.S. National Museum for 1896, 1897 (Wash., D.C., I899), 35I-645, passim. George A. West, "Tobacco, Pipes and Smoking Customs of the American Indians," Bulletin of the Public Museum of the City of Milwankee, 2 vols. (Milwaukee, 1934), passim. Elmer, op. cit., II, I52. Anburey, op. cit., I, 356. 


\section{CHAPTER III}

\section{THE SIMPLE HATCHET OR BELT AXE}

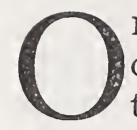

$\mathrm{F}$ all the tomahawks traded to the Indians, by far the most common type was the simple hatchet, or belt axe. This was the type earliest to reach the Indian, and it remained popular from the I6 th through the Igth century. It is the one form found in every part of the United States, even in the Southwest and Florida where axes are rare. This same essential form is still encountered in parts of Canada and Alaska, as well as in Mexico, Central America, and even in South America. Some have been made in the United States for trade to those areas well within the present century.

The basic form of this hatchet was derived from the standard European half-axe. It had a relatively long blade flaring on the side towards the hand so that the edge might be once-and-a-half or twice as wide as the base of the blade at the eye. Normally these hatchets were made in two pieces: a strap of iron was wrapped around a form to make the eye, and the ends of this strap were hammered to make the flare of the blade. A piece of steel was then inserted between them to serve as an edge, and the joints were welded by heating and hammering. Grinding and coarse filing removed the worst of the roughness, and the axe head was completed. (See Fig. 2).

It was a simple object that any competent blacksmith could make in a short time. The cost was low, and the demand was so great that extremely good profits could be made on the furs that these axes could command. Such costs varied naturally from country to country and year to year during the two centuries that this pattern was popular in America, but a relative idea can be obtained from LaSalle's specifications of 1684 for axes to cost 7 or 8 sous per pound and from figures of the I750's and '6o's, when axes of this pattern cost the trader 3 shillings each in quantity. ${ }^{29}$

Even this low cost was not enough to satisfy the greedy, and shoddy products were frequently offered to the Indians by unscrupulous individuals. The usual form of chicanery consisted in omitting the steel edge. This deception was not readily noticeable, and would not be detected unless the buyer understood the prin-

${ }^{29}$ Beauchamp, op. cit., 62. Woodward, op. cit., 9. 
ciples of axe manufacture, knew exactly what to look for, and what tests to make. He would normally be well away from the post before he discovered that his new hatchet would not hold an edge, and even then he might not realize what the trouble was.
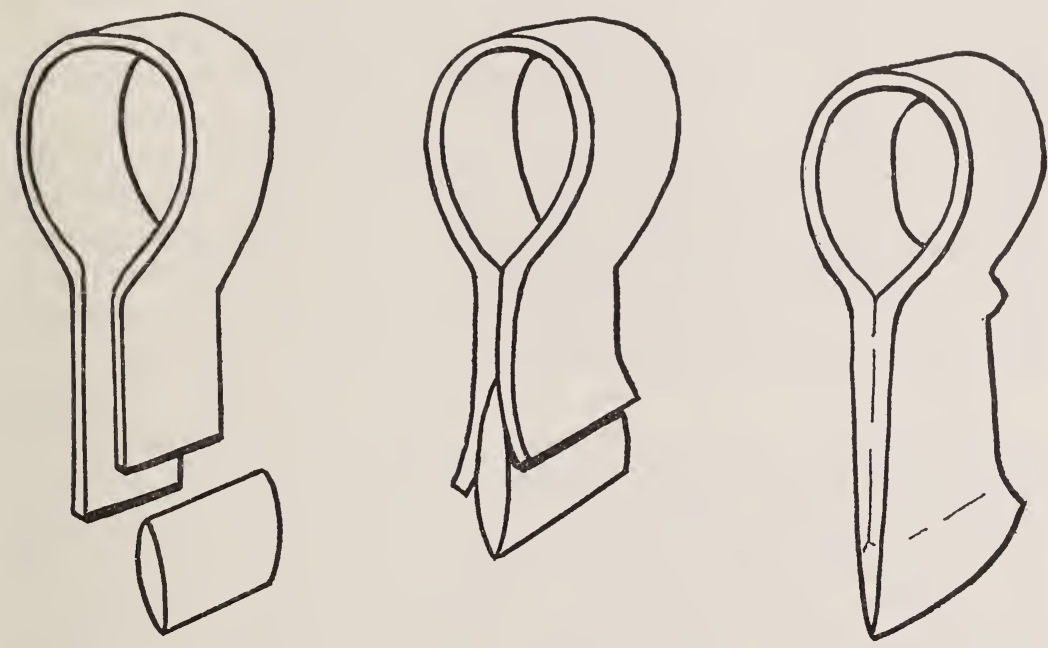

FIGURE 2. Manufacture of a simple belt axe from a strap of iron and a piece of steel.

This deception was the subject of a complaint by the Five Nations of the Iroquois as early as I7oI, when they protested to Robert Livingston, Secretary of Indian Affairs, thus:

Brother. We can not omitt to acquaint you of the deceit of the Smiths who takes our money and instead of putting steal into our hatchetts, putts Iron, soe that as soon as we come into our country to use them they fall to pieces. ${ }^{30}$

Almost a century later, at Fort Laramie in present-day Wyoming, John Bordeau, ferryman and blacksmith, was getting ten beaver skins for the same sort of inferior hatchet which he made out of old wagon tires at almost no cost-and Bordeau even went so far as to stamp his products with his initials in large letters so that they could be readily identified! ${ }^{31}$

As noted elsewhere, the first of these hatchets to come to America were large specimens, almost the size of felling axes. They weighed two or three pounds each, sometimes even more, and ran

${ }^{30}$ Quoted in Woodward, op. cit., 8.

31 Carl Russell, MS. cit., citing a statement by a contemporary of Bordeau's when one of his axes was plowed up in Nebraska, I89o. 
to lengths of seven or eight inches from the top of the poll to the edge. The fact that inventories listing these sizes refer to them as "hatchets" leads one to suppose that they were probably intended to be fitted by the Indians with short hafts and wielded with one hand. Photographs of Indian women in Canada using such hatchets, taken as late as I9I3, tend to confirm this inference. Most of these early axes seem to have been made in two principal European centers: Utrecht in Holland, which is mentioned in reports by Dutch traders along the Hudson; and Biscay in northern Spain, which seems to have been favored by both the French and the English. Axes were also purchased in other European areas, especially in France and England. Apparently the Sheffield and Birmingham areas of England began to displace Biscay as a source of supply for British traders early in the 18 th century. ${ }^{32}$

Despite the fact that the larger sizes continued to be made throughout the whole trade-axe period, some modifications did develop which can occasionally help to establish a date or area of manufacture. First of all, there was a trend toward smaller sizes, which would be easier to carry in the belt and were better balanced as a weapon. One or two such small-sized heads have been excavated at the site of the English colony at Jamestown, Virginia, indicating that they were known before I700, but it appears to have been the first or second decade of the I8th century before the smaller hatchet superseded the larger one completely and relegated it to the position of squaw axe.

Another development is the appearance of the so-called "American" pattern. This followed the evolution of the contemporary full-sized axe. The European axe which the first colonists had brought with them was an inefficient tool. Because there was no true thickened poll, the weight was centered in the blade; this caused the blade to wobble in a stroke. Also, it lacked the extra power that a heavy poll would impart. Since tree cutting was an important activity in America, considerable attention was given to improving the design to make the task easier. First the blade was shortened or otherwise lightened by piercings. Then an extra piece of iron was welded to the top of the eye to form a true poll. Ears were also added to strengthen the attachment of the haft, and, incidentally, to improve the balance by adding more weight near the center (see Nos. 35 and 36). Axes of this type seem to have first appeared in fully developed form sometime between

32 The I9I3 photograph of the woman with the "squaw axe" appears in The Beaver, published by the Hudson's Bay Company (Mar., I946), p. 26. Carl Russell, MS. cit. Innis, op. cit., I5, 72. Beauchamp, op. cit., 65. Woodward, op. cit., 4, 6. O'Callaghan, op. cit., III, I64. 
I725 and I75o, and hatchets of a like design date from about the same period. ${ }^{33}$

In making the new-style hatchets, the same basic principles were followed. A piece of steel was used for the edge, while the eye and poll were formed of iron. Usually the same technique as employed in manufacturing the early axes was used, with the simple addition of an extra piece of iron welded on for the poll. Occasionally, some of the new hatchets were made of four pieces: the steel edge, pieces of iron for either side of the eye, and a fourth piece for the poll (see Nos. 40 and 306). And there were other variations according to the whim and skill of the individual smiths. Some even made the top solid and drilled out the eye, while in the Igth century in the larger factories it was the practice to stamp out the eye with a water-powered punch. Always, however, a separate steel edge was welded in. ${ }^{34}$

It should not be assumed that these newer and better-balanced hatchets superseded the older polless variety. They did not, and in point of fact were always in the minority among the Indians, though white users of tomahawks quickly adopted them.

Among the other variations in the simple hatchet are two which are indicative of specific areas of origin, and deserve special mention. One of them, the so-called "Missouri war hatchet," is so distinctive and found in such quantities that it will be considered separately in Chapter IV. The other is a form which seems to be found in areas of Spanish influence, and is almost diagnostic of such historical relationship. In general, this type resembles the other axes except that it has a rudimentary poll and is always made in three pieces: the steel edge, plus two side pieces. These side pieces are welded together around the edge and below the eye, and then are joined above the eye in a ridge or crest with a noticeable groove along the top (see No. 39). Both full axes and hatchets made in this manner are found in the Southwest, where they seem to have been used entirely as tools. Thus far, none has been reported from Florida or from sites elsewhere in the United States.

${ }^{33}$ Henry C. Mercer, Ancient Carpenter's Tools (Doylestown, Pa., 2nd edition, I950), I-35.

${ }^{34}$ Ibid. Park Benjamin (ed.), Appleton's Cyclopaedia of Applied Mechanics, 2 vols. (N.Y., I880), I, 107, 108. One Hundred Years of Progress (Hartford, Conn., I87I), 339-342. Horace Greeley and others, The Great Industries of the United States (Chicago and Cinn., I872), I22-I33. 


\section{CHAPTER IV}

\section{THE MISSOURI WAR HATCHET}

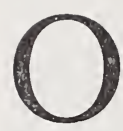

NE of the tomahawk patterns that has been given a specific name with considerable justification is the so-called "Missouri war hatchet." Lewis and Clark found it already in use among the Mandans in January, I805, and subsequent study has indicated that it was popular among such people as the Iowa, Sauk, Fox, Kansa, Pawnee, Comanche, Mandan, Dakota, Osage, and Oto. It has not been reported from the East or South, and only rarely shows up in the area north of the Great Bend of the Missouri River. The territory along that river below the bend and above its juncture with the Mississippi seems to have been both the center of its popularity and the outer confines of its use. ${ }^{35}$

The implement itself is unusually awkward and poorly designed. It seems to be in reality a variation of the simple hatchet, but with the strength and utility removed. Apparently it reached the area via the French sometime during the 18 th century and there quickly achieved greater popularity than any other form of hatchet. William Clark made a drawing of the axe on January 28, I805, and noted that several Indians had visited the camp seeking to have such "war hatchets" made. On January 29, he noted that the expedition's blacksmith was making the axes, since it was the only way they could obtain corn. (See Plates V and VI). On February 5, Meriwether Lewis described the axe in detail:

[The Mandans] are peculiarly attached to a battle ax formed in a very inconvenient manner in my opinion. it is fabricated of iron only, the blade is extremely thin, from 7 to nine inches in length and from $4-\frac{3}{4}$ to 6 Inches on its edge from whence the sides proceed nearly in a straight line to the eye where its width is generally not more than an inch-the eye is round \& about an inch diameterthe handle seldom more than fourteen inches in length, the whole weighing about one pound-the great length of the blade of this ax, added to the small size of the handle renders a stroke uncertain and easily avoided, while the shortness of the handel must render a blow much less forceable even if well directed, and still more inconvenient as they uniformly use this instrument in action on horseback. ${ }^{36}$

35 Meriwether Lewis and William Clark, Journals of the Lewis and Clark Expedition, I804-I806, American Philosophical Society, Codex C., I 58, I63, I64.

${ }^{36}$ Ibid., I63, I64. 
Clark's mention of this axe as a "war hatchet," and Lewis's statement that it was wielded on horseback are particularly interesting (if, indeed, they are accurate) in view of the general impracticability of this type of tomahawk. As Lewis noted, it was made all of iron, without a steel edge, and with an extremely thin blade which was otherwise poorly designed for use. Also, many of the surviving specimens have decorative piercings in the blades, which further weakens them. There is usually no indication of any sharpening along the edge. It is simply left square and blunt. A study of physical characteristics alone would lead to the conclusion that these were merely ceremonial objects-an excellent illustration of the fact that European standards may not always be used in judging the use an Indian may have had for an object.

Size and workmanship vary considerably in the specimens of the Missouri war hatchet which have been studied thus far. The average axe has a height of $7 \frac{3}{4}$ inches from the top of the eye to the edge, and an edge width of $4 \frac{1}{2}$ inches; but some specimens have heights as great as $10 \frac{1}{8}$ inches and blades as wide as 6 inches. Most display simple and crude workmanship, but an occasional well-made example is found, with decorative forged moldings around the eye and at the base of the blade. Among the pierced decorations, the heart is most commonly seen, frequently with a curved tip; this is sometimes called a "bleeding heart." Often there will be punched decorations stamped along the borders, or forming special designs in the center of the blade. The hafts of those later specimens which have survived are usually longer than the $\mathrm{I}_{4}$ inches mentioned by Lewis.

The Missouri war hatchet had a popularity span of somewhat more than fifty years. Since Lewis and Clark found it as an established pattern in 1805 , it was undoubtedly introduced before the end of the 18 th century. The height of its popularity seems to have been between I8Io and I830, but Rudolph Friedrich Kurz sketched an Omaha Indian with one of these hatchets in his hand at Bellevue, Nebraska, as late as I85I and some were unquestionably handed down as heirlooms or for ceremonial use in even more recent times. ${ }^{37}$

${ }^{37}$ The Kurz drawing is reproduced in American Anthropologist, X, No. I (I9I0), II. 


\section{CHAPTER V}

\section{THE SPONTOON TOMAHAWK}

T

HE spontoon tomahawk received its name because the blade resembles that of the military espontoon, a polearm carried during most of the 18 th century by commissioned officers who fought on foot. The espontoon derived from the partizan, an officers' spear of the 16 th and I7 th centuries, and actually most tomahawks of this type resemble the earlier partizan more closely than the I8th century spontoon. Both simple tomahawks and pipe-tomahawk combinations have been found with the spontoon blade. The pipe combination, which is by far the more common form, will be discussed later in the section on pipe tomahawks (see Chapter X). This chapter will consider only the distinctive blade type.

Characteristics of this implement are a spear-point blade, usually symmetrical, with curling flanges, or processes, at or near the

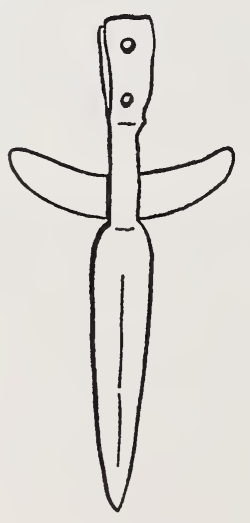

Figure 3. Spontoon type blade. base (see Fig. 3). Usually these processes curve upward toward the haft, but upon occasion (usually in later specimens) they may curve toward the point. In these highly developed late specimens the curve is sometimes complete so that the distal or free end rejoins the blade, giving the effect of a lobe with a hole through its center. In some specimens this hole is omitted, so that there is simply a spear point with a lobed base. Some Igth century versions of the spontoon blade omit even the lobes, leaving simply a symmetrical kite-shaped spear point. For some unknown reason this last variant is often named the "Minnewaukan" type by earlier writers. It has been encountered most frequently in Wisconsin and the tier of states between the Mississippi River and the Rocky Mountains.

Other names by which the spontoon-bladed tomahawks have been called include "dagger-bladed," "diamond-bladed," and "French type." There is considerable justification for the latter designation, since all available evidence seems to indicate a French origin for the design. Many of the earlier writers jumped to the 
conclusion that they were French because they professed to see a resemblance to the fleur-de-lys in the shape of the blade. Since this resemblance is a bit far-fetched and since the fleur-de-lys was widely used in Europe outside France, this would hardly constitute a justification for the association. The best support lies in the fact that almost all of the earliest specimens are found in areas where the French influence was strong: the St. Lawrence Valley and the Lake Champlain waterway, the shores of the Great Lakes, and the mouth of the Mississippi. In all of these areas the concentration is heavy. Others are found on the borders of these regions or in locations that may be explained by migrations or trade. One group of early specimens comes from the Lake George battlefield of I755 where the Indian allies of the French were especially active. Other early specimens come from Tunica burials in Mississippi. Since only the French were particularly active in this latter region in the $I 8$ th century, the origin of these tomahawks would seem to be reasonably well established. ${ }^{38}$

It should not be assumed from this that all hatchets of this type are presumed to be of French manufacture. After the form became popular it was undoubtedly made also by the British and certainly by the Americans. William Clark, in fact, implies that the blacksmith with the Lewis and Clark Expedition made some tomahawks of this type for the Mandans who specifically requested it. ${ }^{39}$ Probably all tomahawks of this type made after I763, when Great Britain finally wrested control of the greater part of the North American continent from France, were of British, American, or possibly Canadian manufacture, except for the very few which might have come in through Louisiana. And even this inlet for French goods was sealed off after the Louisiana Purchase of I803. It is barely possible that some such tomahawks might have been made in France on the order of an American or British trading company, but this possibility is highly unlikely and may well be disregar ded.

All evidence seems to indicate that the spontoon form appeared early in the I8th century. This is corroborated by the recoveries from the Tunica cemeteries in Mississippi, and the finds at the Lake George battlefield. The earliest forms were simple narrow blades often curved slightly toward the rear. The basal

${ }^{38}$ West, op. cit., I, 320, 32I. James A. Ford, "Analysis of Indian Village Site Collections from Louisiana and Mississippi," Louisiana Geological Survey, Anthropological Study No. 2 (Nov., I936), I39. A group of these axes from the Lake George battlefield is in the Fort Ticonderoga Museum. Carl Russell, MS. cit.

${ }^{39}$ Lewis and Clark, op. cit., $15^{8-164}$. 
processes were short, set close to the eye, and almost always curved up towards the haft. Occasionally they made a complete loop. There was no true thickened poll. Unfortunately, no specimens from either Tunica or the Lake George battlefield are included in this study, but No. 259 illustrates the form.

The form found by Lewis and Clark among the Mandans was quite large, "I2 to I5 inches in length [height]" according to their sketch and Lewis's description, in which he termed it an "older fassion" and still more inconvenient than the Missouri war hatchet. $\mathrm{He}$ also indicated that it was frequently pierced for ornamentation with "two, three or more small circular holes." 40

Later in the Igth century simple diamond- or kite-shaped blades developed, as well as exaggerated forms with long narrow stems between the eye and the point at which the expansion of the blade began. The arms or processes also frequently became more elaborate. Decorative perforations aside from the simple circular holes also appear about this time.

In most instances, the spontoon tomahawk was made of one piece of iron looped over a bar and welded to form the eye. Though a very few specimens are known which seem to have been made of a low grade steel, no specimen with a deliberately added steel edge has been encountered. The lack of a steel edge is not surprising. These tomahawks were weapons in their early functional years. Because of their design they would have had no value as woodcutting tools, but the soft iron blade would inflict a serious wound in combat. Thus, a sharp cutting edge of the type needed for cutting wood was not necessary. Since later specimens seem to have been primarily ceremonial in use, they also required no edge, and plain iron remained entirely sufficient for Indian needs. For those specimens combined with pipes, other metals such as pewter and brass were commonly used from at least I750 through the end of the Igth century, but for these simple hatchets without pipes, iron remained standard.

40 Ibid., I64, I65. 


\section{CHAPTER VI}

\section{THE HALBERD OR “BATTLE AXE” TOMAHAWK}

A

NOTHER variety of tomahawk named after a European polearm is the halberd type. This was a polearm weapon consisting of an axe blade with an opposing spike or hood, and crowned with a spear point (see fig. 4). Mounted on a long haft, it had developed as a weapon in the late I4th century. By the I 8 th century it had become largely a ceremonial arm carried by sergeants in most armies and by honor guards and court officials. On a short haft, it resembled the layman's conception of a battle axe; thus, both names have been applied to tomahawks of this classification.

The halberd tomahawk developed early in the I8th century and was apparently of British origin. Most surviving specimens come from the areas of New York and New England where British influence was strong, and a very few specimens are known from the southern Great Lakes area that may have migrated there from the east. At least one specimen has been recorded as having been made by $R$. Beatty of Pennsylvania during the second quarter of the century, and is reputed to have belonged to Daniel Boone, who took it with him to Missouri toward the end of his life.

An excellent contemporary illustration of the halberd tomahawk which is also further evidence of its British origin is found in the mezzotint portrait of the Mohawk chief, King Hendrick, published in London prior to his death at the Battle of Lake George in I755 (see Pl. VII).

The halberd tomahawk was made in a manner quite different from the types previously described. Usually forged from one piece of steel, it was normally quite thin and light. There are examples made in two or more pieces, however, and in these instances the blade and spike were usually forged separately from two or three pieces of metal, and then welded to the spear point and shank, which were made from one piece. One specimen in the 
Museum of the American Indian appears to have been made from an actual halberd (see No. 54).

A special characteristic of this form of tomahawk is that it was commonly attached to the haft by driving a shank into the wood. This shank, usually forged as one piece with the rest of the head, was often sharpened for easier penetration and sometimes roughened or barbed to make it hold more securely. A ferrule would also normally be placed around the forward end of the wooden haft to strengthen the joint. In this connection, it might be mentioned that one object frequently mistaken for a halberd tomahawk or, sometimes for a "Viking halberd," is the plug cutter used for Battle Ax Plug Tobacco in the early I89o's. Although slight variations exist, this cutter is usually made in two pieces-a cast iron section including the socket and spike, and a thin steel edge attached by means of two rivets or screws. ${ }^{41}$ It is fastened to a wooden cutting board, as shown in Plate XIII.

As a form, the halberd tomahawk did not last very long. Less than fifty years would probably cover its active life. Some specimens are well balanced and practical, but many are fantastically designed and poorly balanced. Light hooks with no point or edge are found in place of the spike, and extra-long spear points, sometimes with barbed ends, made them difficult to carry. In fact, it has been asserted that the inconvenience caused by these spear points was the principal reason for the abandonment of this type. Since tomahawks were usually carried thrust through the belt at the right side and slightly to the rear, the spear point could thus easily become a nuisance or even a danger. The spear point actually was of little or no value in fighting ; it did offer one more possibility of striking a victim with a cutting edge if thrown end-over-end, but it sometimes hindered a stroke when held in the hand. Halberd tomahawks also were weapons only, since they were too light for effective chopping even of small branches. More efficient tomahawks that could also be used as tools were available, and so the halberd type disappeared.

41 R. W. Breckenridge, "Norse Halberds," American Anthropologist, LVII, No. I, Part I (Feb., I955), I 29-I3I. Letter from V. J. Boor, Assistant Advertising Manager of the American Tobacco Company, to Charlie R. Steen, Apr. I6, I953. 


\section{CHAPTER VII}

\section{THE SPIKED TOMAHAWK}

A companion of the halberd tomahawk and its successor was the spiked tomahawk. The use of hatchets and axes with spikes on their polls as fighting weapons-and particularly as naval boarding axes-was common to all nations of western Europe, but the British appear to have been responsible for the introduction of the light hatchet, with a spiked poll, to the American Indian.

As might be expected with an arm of British origin, its area of use was within the English sphere of influence. Since it was also an early form which developed shortly after I700, achieved its greatest popularity about the middle of the century, and began to disappear shortly after I8oo, it was confined largely to the Atlantic coastal region. Within that territory it is found principally in the area north of Pennsylvania, although a few are encountered as far south as Virginia. A small number have been recovered from sites in Michigan, Ohio, Indiana, and Illinois, where the British were active following the French and Indian War, and a very few scattered specimens have been found further west, possibly as a result of trade or migration.

The spiked tomahawk served well as both a tool and a weapon. The spike was useful in driving small holes, in loosening ground, in forcing openings, and for many other needs. Some spikes were curved and sharpened along the edge like a pruning knife, thus providing an effective cutting edge for use in situations where the normal edge could not operate. In some instances the spike was simply a hook with a point on the end, but without an edge, so that it could be used for catching and hauling. In warfare, the spike allowed the use of a backstroke and the chance for deep penetration in a narrow area, as happened on one occasion during a fight in I778 at Harbert's Block House, in what is now West Virginia. On this occasion, a young borderman named Edward Cunningham is reported to have wrested a tomahawk from an attacking Indian, and driven the long spike deep into his back. ${ }^{42}$ Further evidence of their use in warfare is suggested by the large numbers of

42 Woodward, op. cit., 20, 21, citing Alexander Withers, Chronicles of Border Warfare, 7th edition (Cinn., I920), 238. 
spiked tomahawks recovered at Fort Ticonderoga, and on the Lake George Battlefield; these are now on display at the Fort Ticonderoga Museum. In the Rhode Island Historical Society

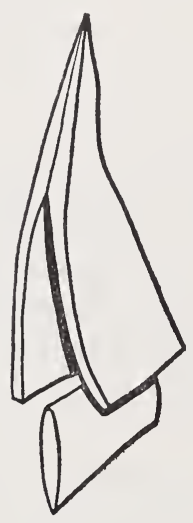

FIGURE 5 .

Construction of a spiked hatchet with two pieces of iron and a steel edge. there is a complete specimen which was carried by a soldier in the colonial wars.

In early examples, spiked tomahawks were sometimes made with shanks for insertion into a wooden shaft in much the same manner as the usual halberd type. In such instances they were normally forged from one piece of iron or steel. One specimen found near Rome, New York, seems to have been made by applying a small conical spike to a standard half axe. ${ }^{43}$ Another, found in Pennsylvania, was made entirely of cast brass. These are exceptions, for most spiked axes were made of two or three parts. Usually two pieces were welded together around an iron handle pattern to form the eye; then, if desired, a piece of steel was fastened between them to form the edge (see Fig. 5). Sizes varied tremendously, from that of a small hatchet to the dimensions of the full axe. The weight, however, remained relatively light, so that they could be used with one hand.

${ }^{43}$ Beauchamp, op.cit., 65. The specimen is in the U.S. National Museum. 


\title{
CHAPTER VIII
}

\section{TOMAHAWKS WITH HAMMER POLLS}

\begin{abstract}
Closely akin to the spiked tomahawks were a small group of implements with hammers on their polls. Hatchets with such hammers, including lathing and shingling hatchets, had been standard tools in Europe, and some of the examples found in Indian sites seem to have been intended originally as tools (see Figs. 6 and 7). Others quite definitely were designed to be used for military or ceremonial purposes. In some of these the hammer head is too small in diameter to have been used for efficient pounding and must have served somewhat as a dull spike. In others the mouldings are decorative, and there are inlays and engraved decorations on the blades which indicate such uses. One specimen is even inscribed "To your arms Solder," and bears a silver crescent inlay engraved with an Indian name which is now so worn as to be illegible (see No. 92).
\end{abstract}

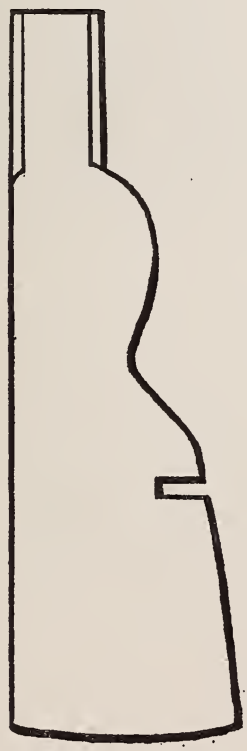

Figure 6. Lathing hatchet.

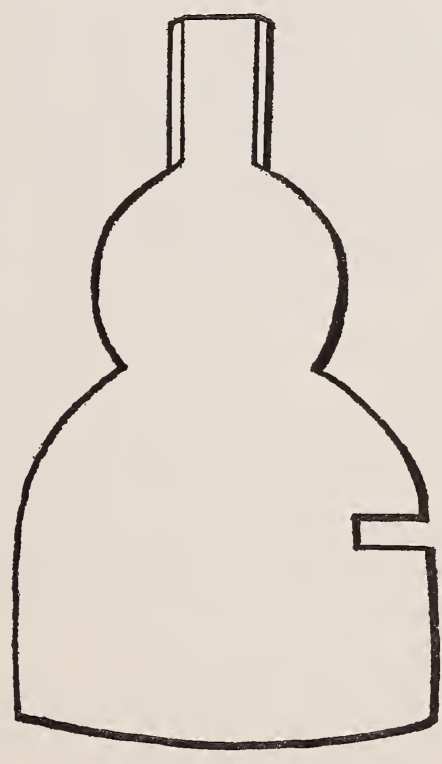

FIGURE 7. Shingling hatchet. 


\section{CHAPTER IX}

\section{CELTIFORM TOMAHAWKS}

$\mathrm{O}$ NE of the oldest forms of the tomahawk is the stone axe blade lashed to a wooden haft. These are quite common in archeological excavations, and form a specific type to which the name celt has been applied (see Nos. 8 and 9). In those regions where local circumstances permitted, occasional celts were made of native copper in prehistoric times. These implements performed the dual services of tool and weapon, and with them the Indian accomplished most of his wood cutting and combat.

An interesting version of the trade tomahawk which reflects this earlier implement is the simple iron celt. Sometimes these were of European manufacture, yet in many instances the Indian himself fashioned them from bits of iron obtained from whites. This was never a widely popular type, yet such celtiform tomahawks do appear in scattered examples over a wide part of the United States, and represent a considerable period of usage. The Great Lakes region and the Northeast, where the copper celt was most frequently made, have produced examples of the iron celtiform tomahawk dating from the I8th century. One has been found in Florida, and a few have been discovered among the Plains and Mountain tribes as late as the I840's. One very late specimen, obviously only of ceremonial importance, has a thin blade cut from sheet copper (see No. I05). 


\section{PLATES}




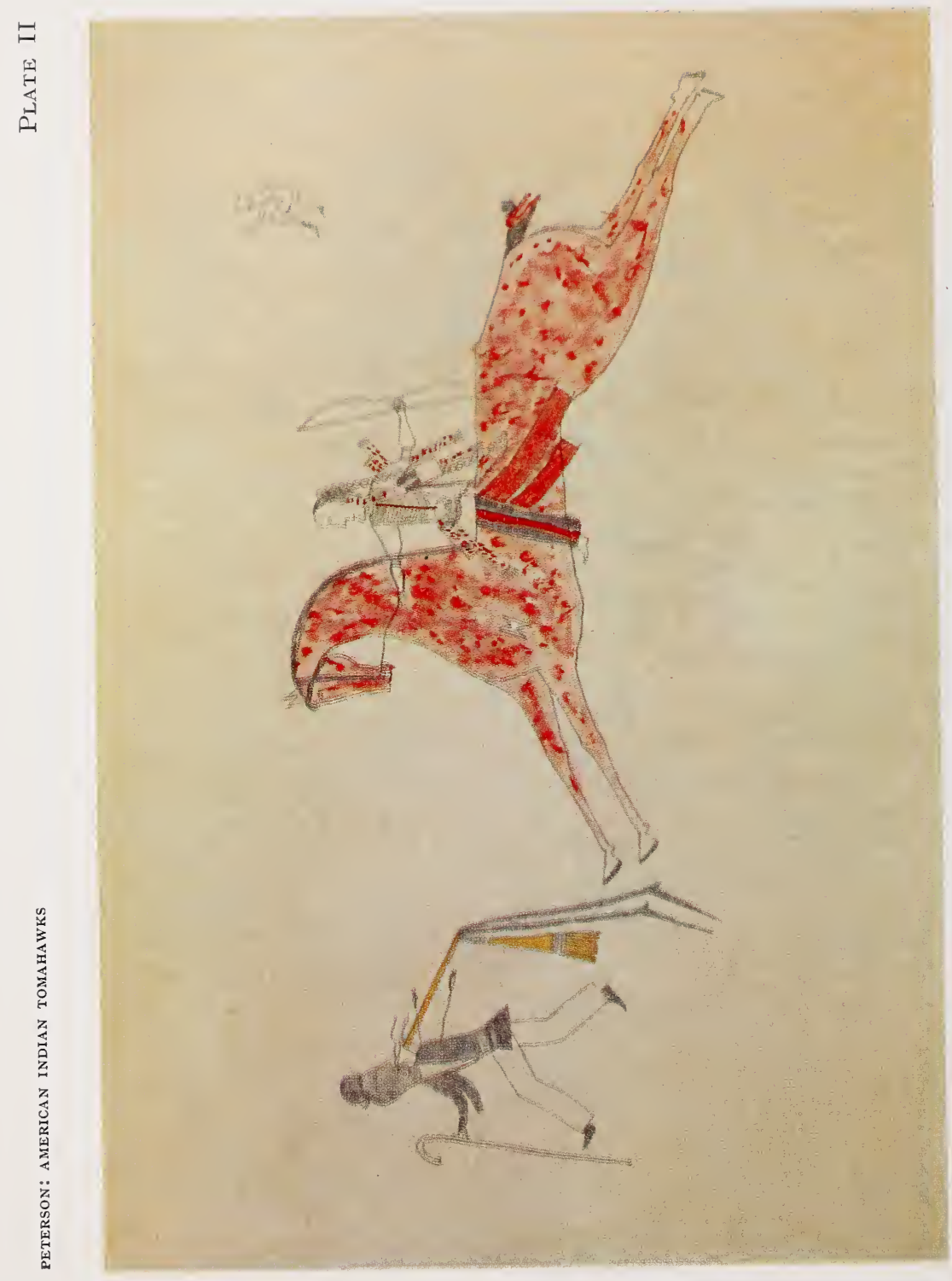

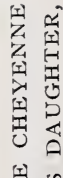

密量

के

舀点

学

क

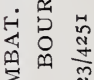

००

学

势

z

出

ब

ठิ

$4>0$

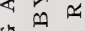

空

o 능

党

벙엉

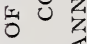

0
$\approx$
$\infty$

4

壱占

0

更

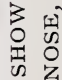

들

엉

雷

융

is

空舅 


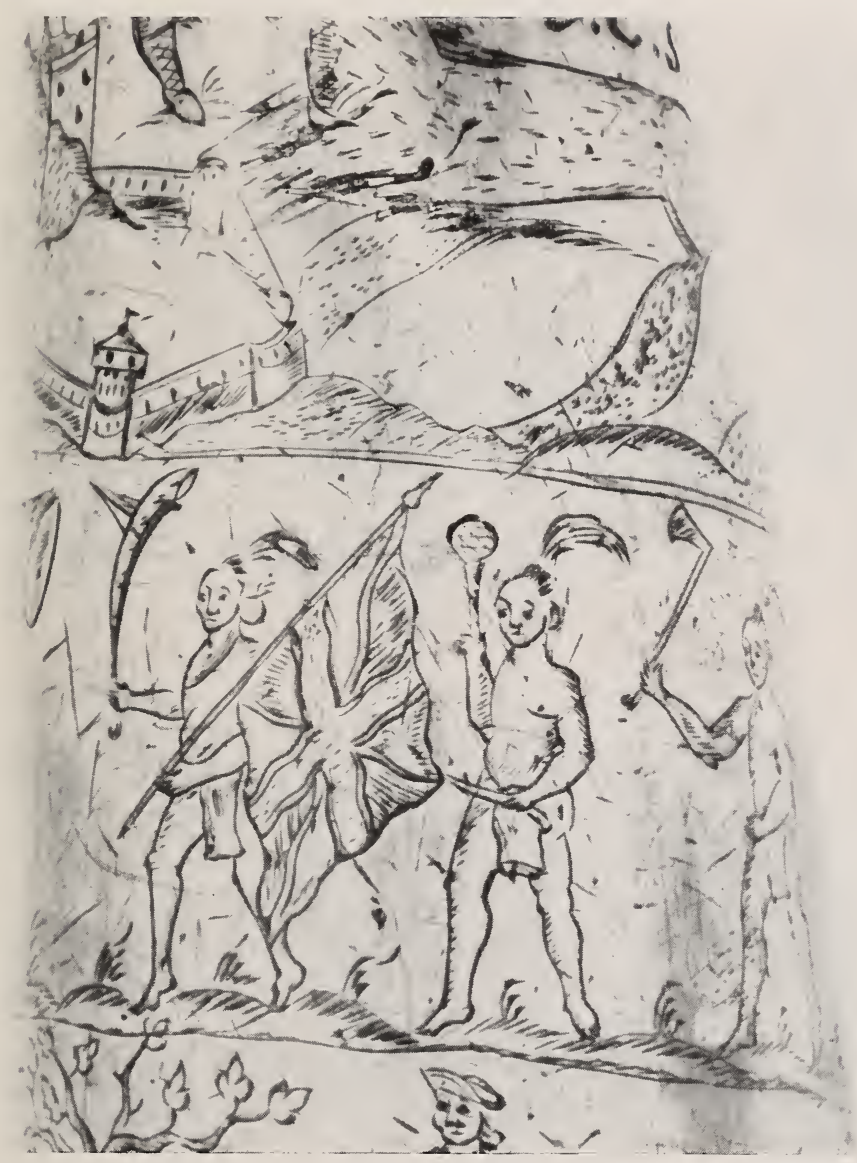

AMERICAN ENGRAVED POWDER HORN OF THE MID-I8TH CENTURY, ILLUSTRATING THE GUNSTOCK CLUB, THE BALL-HEADED CLUB, AND THE SIMPLE BELT AXE CARRIED BY INDIAN WARRIORS. 


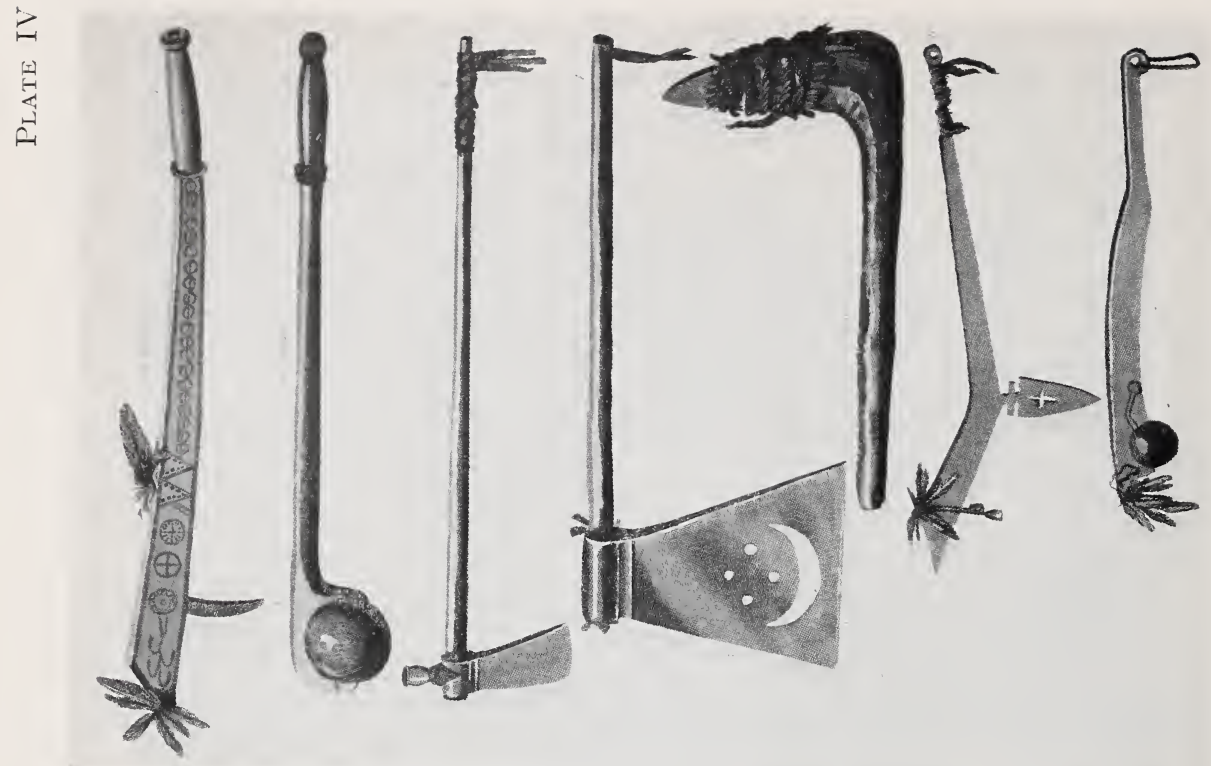

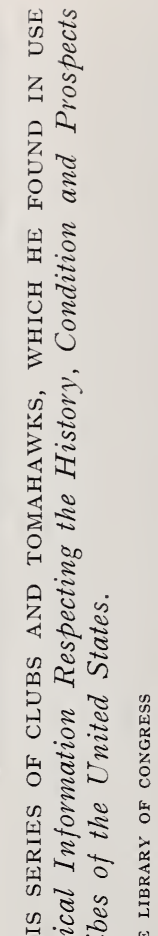

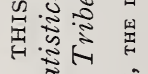

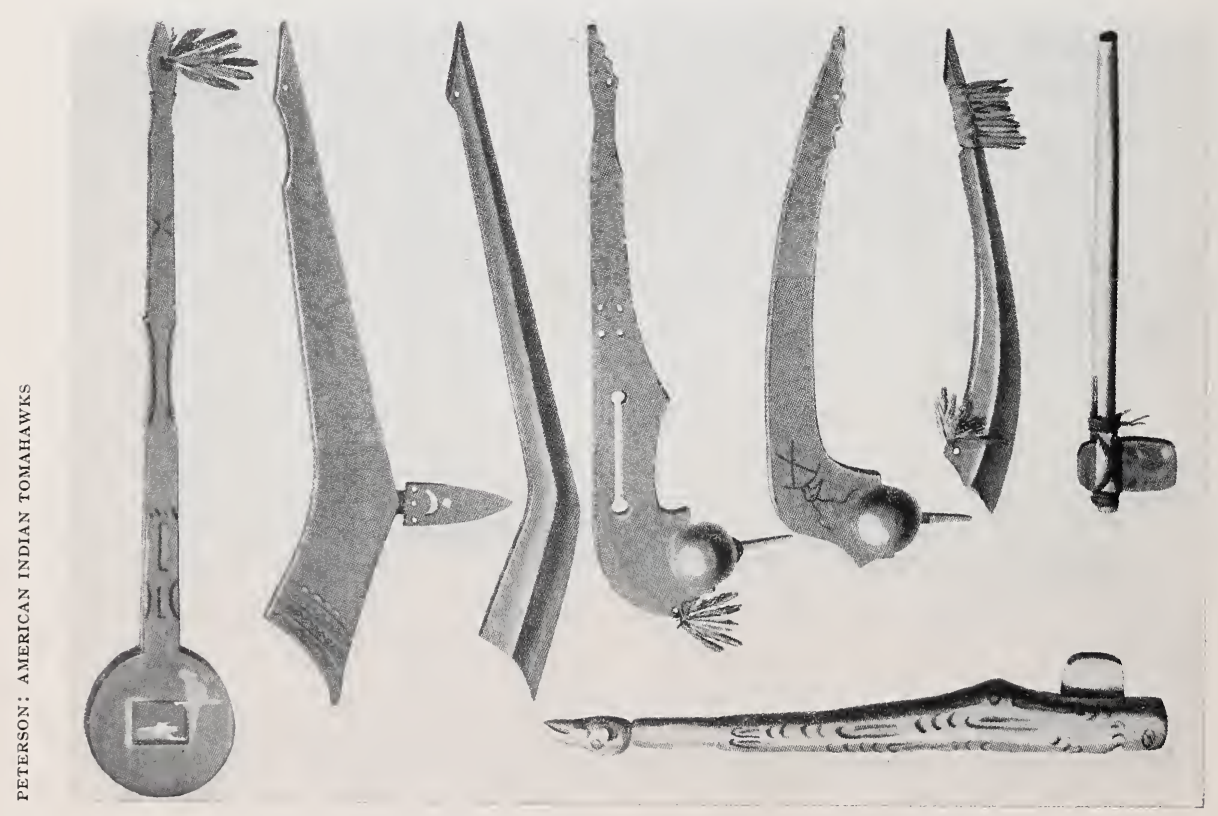

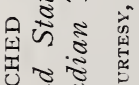

芯芯

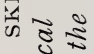

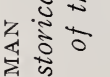

岳漓

द

स

焉空

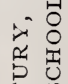

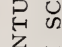

至

出受

亩

是

空密

突

至莲 


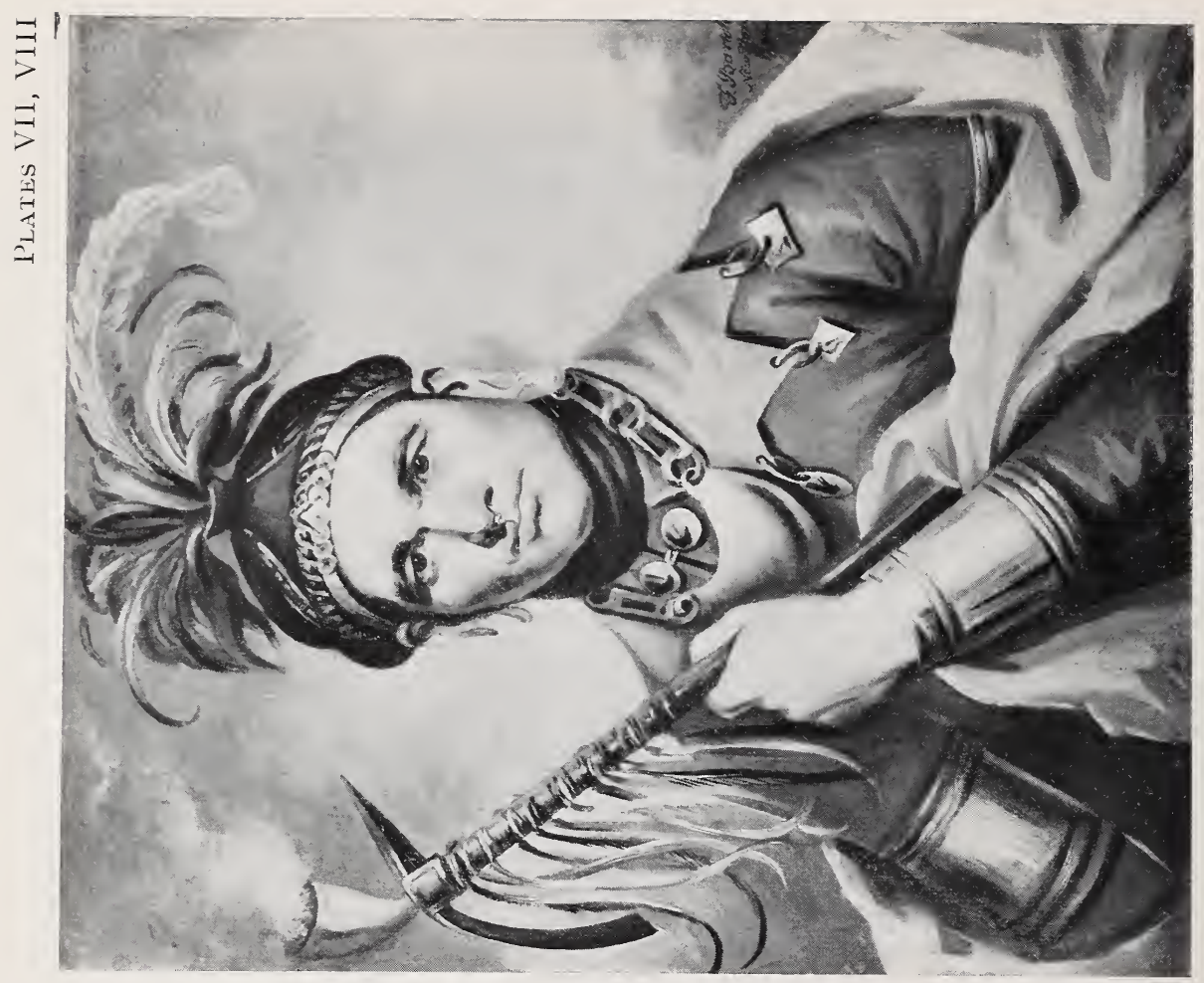

告者

造这

$\rightarrow 0$

的 0

ज承

究

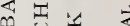

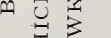

2

$0 \leqslant$

곤

$3+$

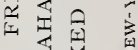

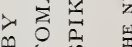

- जิ $\approx$

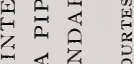

द 4

- जी is

需 4

ज形

艺玒号

슬 되

杂会至

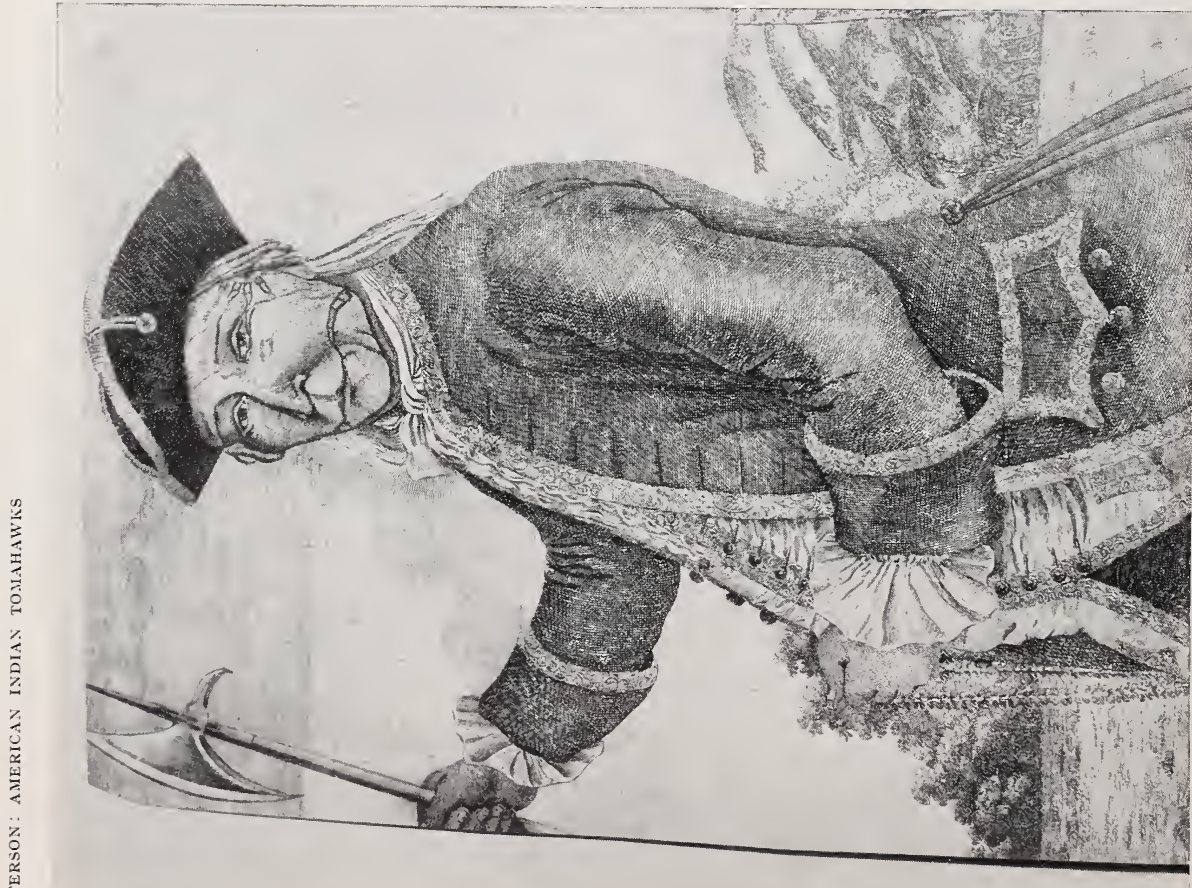

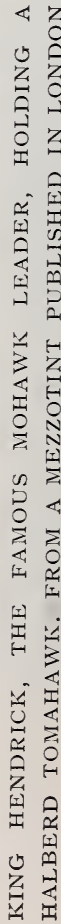



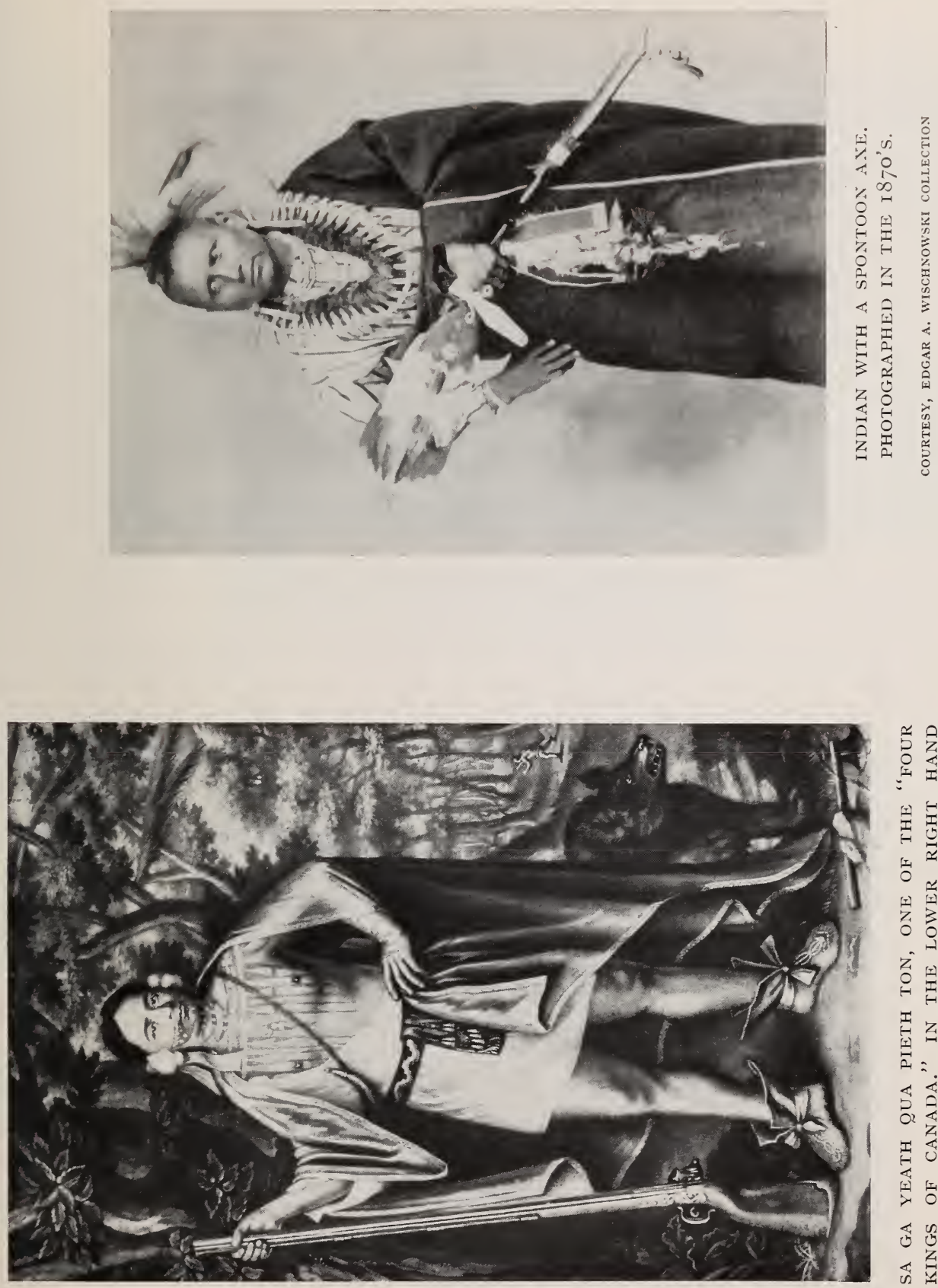

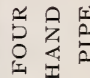

4

国忽穿学

동 死 क

(1)

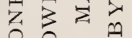

다의

台国军

웁ㅎํㅇ

焉资式

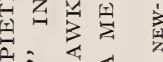

A = 4

屯安焉思

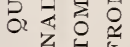

I

द的是

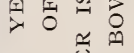

ड

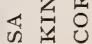



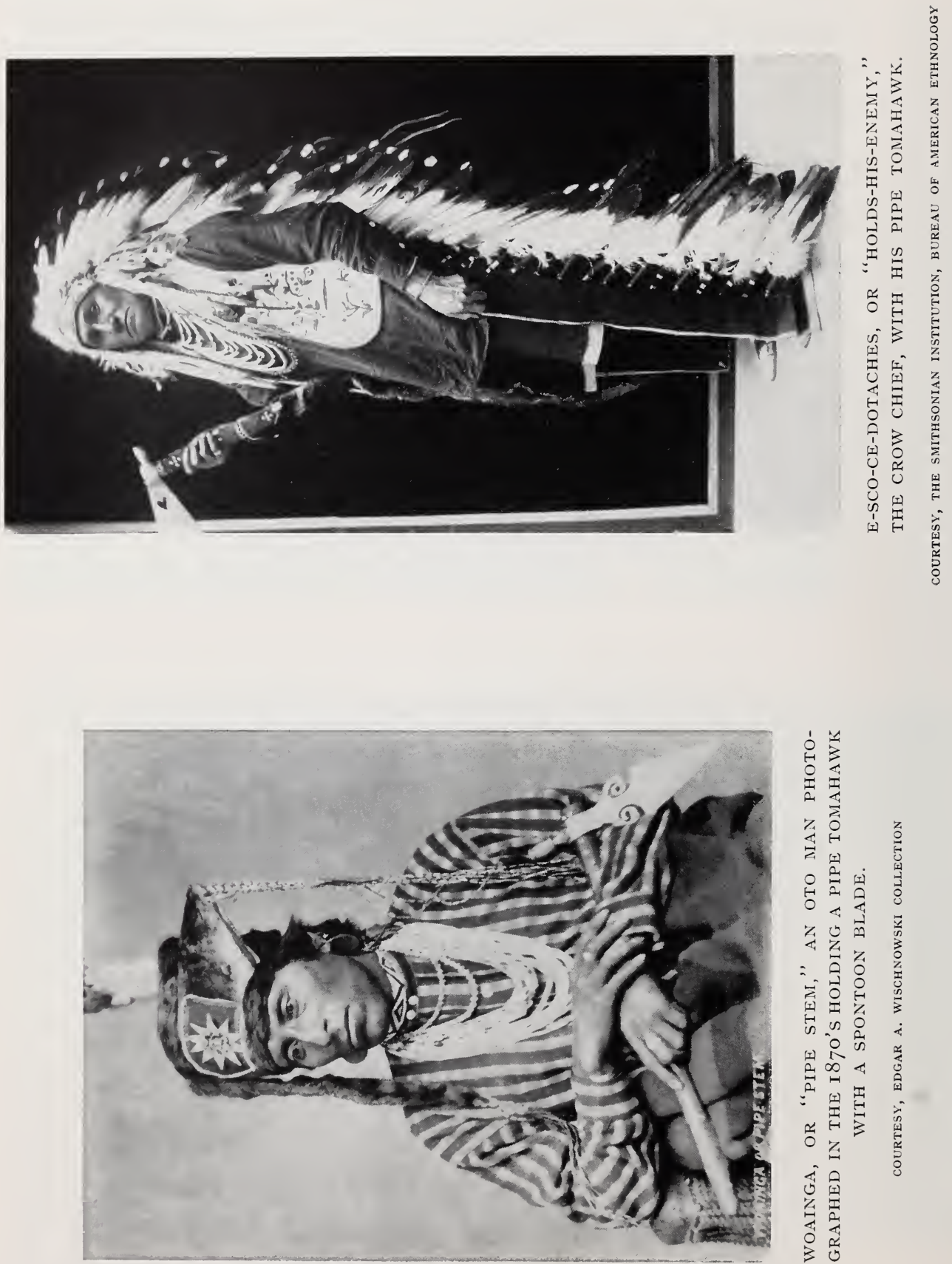


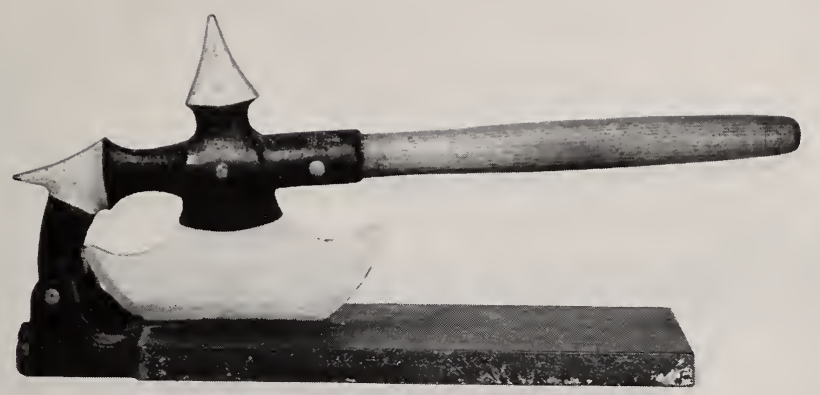

PLUG CUTTER FOR BATTLE AX PLUG TOBACCO, LATE I9TH CENTURY. HEADS BROKEN FROM PLUG CUTTERS SUCH AS THIS ARE OFTEN MISTAKEN FOR TOMAHAWKS OR EARLY POLEARMS. L: $17 "$ MAI/HF: 23/223I 



\section{CHAPTER X}

\section{THE PIPE TOMAHAWK}

$\mathrm{O}$ $\mathrm{F}$ all the types of tomahawks, by far the most popular was the pipe tomahawk. No other form was made in so many different designs, nor of as many different materials. Excepting for the simple hatchet or belt axe, none was made for so long a period nor in such large numbers. Here the symbols of war and peace were combined in a single instrument, which quickly became a prized possession. Henry Timberlake observed it among the Cherokees in the I750's, and declared: "This is one of their most useful pieces of field-furniture, serving all the offices of hatchet, pipe, and sword." He might have added the symbolic power of the mace as well, for the ceremonial functions together with the smoking rituals permitted the survival of the pipe tomahawk well after its usefulness as a weapon had diminished. ${ }^{44}$

The identity, and even the nationality, of the genius who invented the pipe tomahawk is unknown. In all probability it was some Englishman who visualized, even before the turn of the I8th century, what a great attraction such an instrument would have in trade and Indian affairs in general. At any rate, pipe tomahawks, or "smoak tomahawks," as they were then called by the English, were known within a few years thereafter. When J. Simon engraved the portraits of the "Four Kings of Canada" (they were Iroquois chiefs) who visited London in I709-I7Io with Peter Schuyler, he included what may have been pipe tomahawks with symmetrically flaring blades among their accoutrements (see Pl. IX), and a similar tomahawk is shown in a posthumous portrait of King Philip which appears in Thomas Church's Entertaining Passages Relating to Philip's War published in Boston in I7I6. By I750, pipe tomahawks were common though relatively expensive items in trade and treaty lists in the East, running from I2 to 20 shillings for fine specimens, as compared with 3 shillings for the simple hatchets. Once known and available, their popularity was never seriously challenged. ${ }^{45}$

44 Timberlake, op. cit., 77,78 .

45 Woodward, op. cit., 9, I3, et passim. Carl Russell, MS. cit. West, op. cit., I, 3I 7-325. 
The earliest of the pipe tomahawks manufactured by Europeans were fashioned from iron and steel, and these materials continue to be most commonly used up to the present day. By I750, brass tomahawks with inletted steel edges were known, and they continued in parallel use with the iron types until about I830, after which date the steel edge was generally omitted. The combination of brass and steel was expensive because of the extra work involved in careful inletting and joining, and as the pipe tomahawk declined in importance as a weapon, the steel edge was eliminated in favor of all-brass heads. An occasional specimen is found from a later date, but it is a rarity. Pipe tomahawks made of pewter also are found in a variety of styles for a period of at least a century, from about I800 to I900. In no instance, however, has a pewter head been found in combination with a steel edge. Cast iron also has been used in very recent specimens for ceremonial purposes, and, for a short time around rgoo, heads made of nickel-plated brass were manufactured.

Indians also made pipe tomahawks for their own use, although apparently this was always on a small scale. A portrait of the Seneca chief, Cornplanter, painted by Frederic Bartoli in I796 (see Pl. VIII), illustrates a pipe tomahawk which seems to have been assembled from a spiked hatchet of exaggerated form and a clay pipe. From this picture it appears that the haft of the hatchet had been pierced to form a stem, and the pipe bowl simply inserted in the end opposite the mouthpiece. This would have been a simple way of making a pipe tomahawk combination, and may well have been practiced more than is now realized, since the bulk of simple hatchets and spiked tomahawks that have survived are archeological specimens of which only the iron heads remain. It is also entirely probable that some brass and pewter specimens were made by the Indians, for they had been capable of casting both metals since the middle of the $I 7$ th century. When John C. Ewers of the Smithsonian Institution was working among the Plains Indians, he was told that they had cast pewter tomahawks in wooden molds until about I9oo. As blacksmiths were sent to live with the various tribes, some Indians undoubtedly learned to forge iron, and one pipe tomahawk in the Museum of the American Indian is known to have been the work of such a Chickasaw blacksmith (see No. I3I). Later, catlinite became popular for this purpose, and decadent specimens are still being made for the tourist trade. ${ }^{46}$

All types of blades were used in combinations with the pipe. Cornplanter's spiked pipe tomahawk has already been mentioned. In the collections of the Museum of the American Indian and ${ }^{46}$ West, op. cit., I, 3I7-325. Statement by John C. Ewers to the author. 
the U. S. National Museum are halberd-type tomahawks with detachable pipe bowls, which may be screwed into place as desired (see Nos. 107, 108). The symmetrically flaring hatchet blade is known in the earliest pictures of pipe tomahawks. The spontoon blade is pictured with a pipe as early as 1757 , and this combination continued in common use until after I9oo. The half-hatchet form, with an outward flare on the side toward the hand only, was undoubtedly the most common blade used, especially among the English specimens, until it was surpassed by the thin blades with expanding straight sides of the so-called "Plains Indian type" that became popular after $1850 .{ }^{47}$

The earliest of the pipe tomahawks were large sturdy implements, useful as weapons or tools as well as for smoking and ceremonial purposes. The eye was large, to receive a haft strong enough to deal a heavy blow without snapping, even though there was a hollow channel running through it. Usually this eye was shaped like a teardrop with the point down towards the blade. Some, however, were oval. As time passed, the eye tended to become more circular and smaller until, about I8I5-I830, some specimens were made with round eyes a scant five-eighths of an inch in diameter. In another line of development, the oval eye became first straight sided, or a pointed ellipse, and then diamond shaped. By I850, the diamond form was almost universal.

An interesting feature of the eye is the fact that in almost all forms it tapers slightly toward the rear or hand side. This was done because the haft also tapered and was normally inserted from the front, in the manner of a pick handle today. The mouth end was inserted first, and the entire haft passed through the eye until the head lodged in place, just short of the forward end of the haft. A few specimens are encountered with eyes which do not taper; these are usually late pieces, and a very few are known in which the haft actually was cut down and inserted from the back. These are the exceptions to the rule, however, and either is a cause for immediate suspicion that the whole piece-or at least the haft-may be modern, unless all the other evidence outweighs it.

Pipe bowls evolved in shape, as did blade forms and eye openings. The early bowls were short and of large diameter; the sides were rounded, and they usually tapered slightly inward toward the top. Gradually the bowls became taller, the sides became straighter, and the diameter decreased. By I850 a straight-sided or slightly barrel-shaped bowl with a single molding at top and bottom was standard. Thereafter, forms became even more ex-

${ }^{47}$ The pipe tomahawk with spontoon blade is shown in Thomas Jeffery, Collection of the Dresses of Different Nations, (London, I757-I772). 
treme until, by the end of the century, an attenuated vase shape resulted. Throughout the entire period other forms of the bowl are encountered with hexagonal, octagonal, or otherwise faceted sides. But in all forms, the general progression from short and wide to tall and slender seems to hold true.

The addition of the pipe bowl created new problems for the tomahawk maker. Sometimes he made the axe and bowl separately and then joined them, and at other times he adopted an entirely different manufacturing technique, making the entire unit in one piece.

There were several ways of manufacturing a bowl and axe of iron separately and then attaching them. Usually the smith made the desired type of blade in the manner usual for that pattern. Then he forged the bowl, occasionally shaping it from a solid block; more often he wrapped a flat piece of iron around a mandrel and welded it. The bowl could then be keyed and mortised to the poll of the axe and brazed or welded in place. Some specimens have also been found in which a tube from the bowl was passed through a hole in the poll and riveted inside the eye. Some bowls were threaded so that they could be screwed into the poll of the axe. One specimen in the Museum of the American Indian has a pipe bowl that can be unscrewed and replaced with a hammer, which is similarly threaded (see No. 2I5).

If an iron pipe tomahawk was to be forged in one piece, the smith usually began by making a tube. If an old gun barrel was available, he could use a section of that and thus save the first step. Rifle barrels were preferred because they were thicker and thereby provided more metal to work with than the thin musket barrels. Once a tube of the proper length was ready, the base of the bowl was necked-in and a rough shape given to the bowl. Then two cuts were made opposite each other just below the neck and the sides of the tube in the area of the cuts flattened out and shaped to form the eye. An iron handle form was put in the eye to hold its shape, and the remaining tube below was flattened and shaped to form the blade (see Fig. 8). If desired, a piece of steel for the edge was sandwiched in and welded to complete the job. Pipe tomahawks made from rifle barrels in this fashion can be readily recognized by the traces of rifling still inside the bowl.

Some iron pipe tomahawks were cast, but these were usually late pieces for ceremonial purposes only and were not intended for use as either tool or weapon. With brass and pewter pipe tomahawks, casting, of course, was the normal procedure, and usually these were made in one piece. In some brass specimens, however, the bowls were made separately and threaded to screw in place. 
Iron molds were the rule, though sand also seems to have been used occasionally. Some of the pewter axes may have been cast in stone molds and, impractical as it may seem, the reference to wooden molds mentioned above should be recalled.
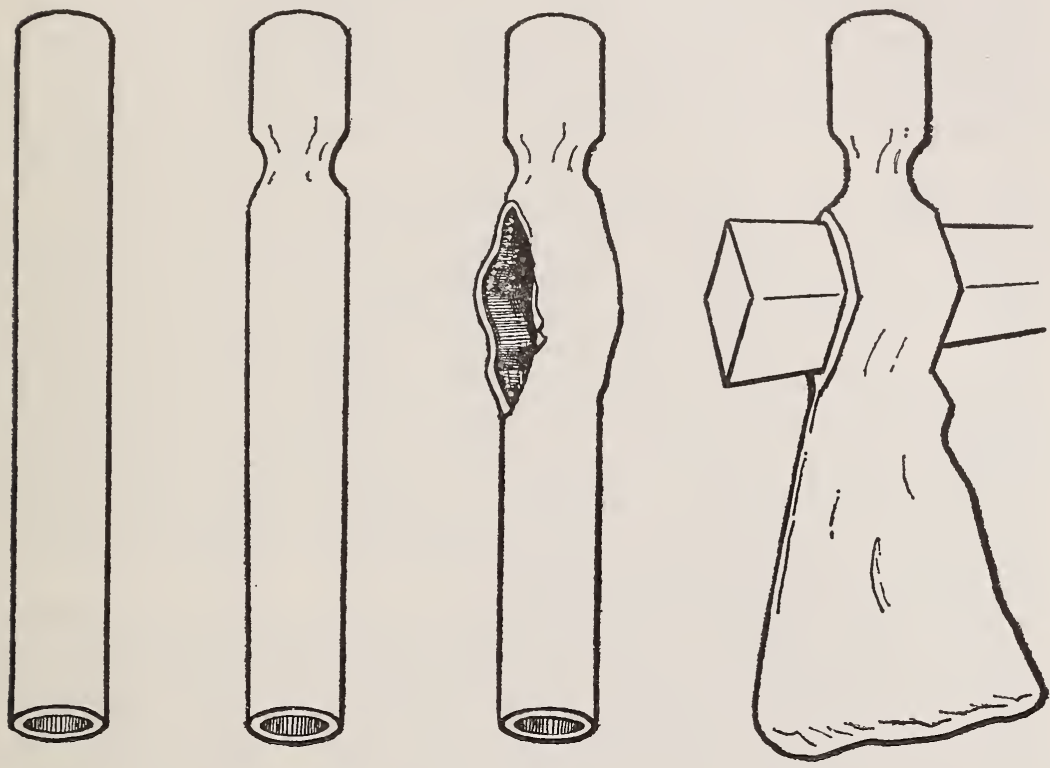

FIGURE 8.

Method of forging a pipe tomahawk in one piece from an iron tube.

The brass tomahawks with steel edges required careful joining. Normally the edge was formed with a dovetail projection in the center matching a like opening in the brass part. This prevented forward or back motion. To prevent movement from side to side, grooves were opened in the sides of the cut in the head, and the edges of the steel to be joined were tapered. These tapered edges were forced into the grooves in the head, and the brass was hammered down over them. To complete the joint, melted tin, solder or pewter was used as a seal. In some instances brass rivets were driven through the head above the joint for further strength. In rare instances the edge was simply riveted to the head without dovetailing; in late specimens the edge was simply inserted in a groove in the lower edge of the head, or even placed in a mold and the brass head cast around it.

Hafts or stems were almost always made of hardwood. If made in Europe, or by a white man in America, any sort of tough hard- 
wood might be selected, though ash, walnut, maple, or hickory seem to have been preferred. The hole was then drilled through from end to end. The Indian, lacking such drills, usually selected ash and burned the pith out with hot wires to make the hole. This hole went completely through from one end to the other. A bit of rawhide or occasionally a wood or metal plug closed the forward end. In decorated specimens a metal cap might cover the entire end of the haft beyond the head. At the end of the haft designed to be placed in the mouth, the wood was narrowed to a convenient size. Sometimes a separate mouthpiece was added; this might be a metal inlay or a carved bone, ivory or horn piece the diameter of the haft, or it might be a small metal tube (perhaps fashioned from a cartridge case), the quill of a feather, or a reed inserted in the hole itself. Around the haft where it lodged inside the eye of the head was wrapped a gasket or shim of paper-thin leather; this gasket, almost always present on early specimens and characteristically charred, is almost impossible to reproduce. Thus, along with the proper taper of the haft, it offers a good clue to the authenticity of the stem. In late specimens not designed for use, this gasket was sometimes of cloth.

Hafts were decorated in a number of ways according to the abilities of the maker and the customs of the tribe. In the East the earliest specimens from the period before 1800 were normally polished smooth and slightly cigar shaped toward the mouth end. Decoration consisted primarily of metal inlays and bands of lead, pewter, brass or silver as a rule. Sometimes incised pictographs or symbols are encountered, but these are less common. Paint was undoubtedly applied more than might be suspected from surviving specimens, since the great bulk of aboriginal hafts has been lost. On occasional specimens, the hafts were wrapped and burned in "tiger stripes" in much the same fashion as some early rifle stocks.

Around 1800 the lower edge of the haft began to be carved in a series of scallops. This innovation has been attributed to the Chippewa but, whether or not this can be substantiated, it did become popular among many of the Great Lakes and western Plains tribes, and continued so for at least the next 75 years.

Other later (and usually western) innovations included the branding of the stem with a hot file, the addition of numerous brass-headed tacks, the practice of wrapping the haft in brass or copper wire, and the attachment of colorfully beaded flaps (see frontispiece). The provision of a small carved protuberance on the bottom of the haft, pierced for a buckskin thong, is also a Igth century characteristic, and is almost always western. Usually a few beads, feathers, brass tinklers, or perhaps an eagle-claw 
charm, were tied to this thong (see No. 20I). This is not found in the East except in some very late I9th century specimens used for ceremonial purposes.

Another form of decoration included the use of feathers and cloth. Feathers were used for ornamentation in the East, if we may judge by the 1796 portrait of Cornplanter, and cloth wrappings must certainly have also been employed. Since both materials are of a perishable nature, all specimens illustrating this practice are western and date from the I9th century (see frontispiece and Nos. I72 and 176 ).

Closely allied to the subject of decoration was the special use of the tomahawk as an important gift to cement a friendship or to seal a treaty. Such "presentation tomahawks" are almost always pipes, and normally they were highly decorated with inlays of silver, or occasionally gold, in both haft and head (see Nos. I34 and 256). Coats of arms, names, dates, and other inscriptions were sometimes engraved upon them as well. One particular bit of symbolism occasionally encountered on such axes of the I8th and early I9th centuries was the "silver chain of friendship" mentioned frequently in the formalized orations that were an integral part of the Indian councils of that period. This chain ran from a band around the haft near the mouthpiece to another band near the head, or even to the head itself. In I86o Benson J. Lossing sketched a portrait of Chief G. H. M. Johnson of the Six Nations holding a tomahawk with such a silver chain that had been in tribal ownership for many years. Another tomahawk with a silver chain of friendship belonging to Chief Bowles of the Cherokee is now in the Museum of the American Indian (see No. 133). ${ }^{48}$

Thus the pipe tomahawk served its various functions and passed through its many mutations. The Iroquois chiefs who went to the court of Queen Anne in I7ro carried pipe tomahawks with them, as did the Crow chief, Holds-His-Enemy, when he went to Washington in rgro (see Pl. XI). The two centuries which intervened saw it spread to every part of the United States where metal tomahawks of any sort were used and quickly become the most popular form of all.

${ }^{48}$ Lossing, op. cit., $42 \mathrm{I}$. 


\section{CHAPTER XI}

\section{THE WHITE MAN AND THE TOMAHAWK}

\section{$\mathrm{T}$}

HE Indians were by no means the only peoples in America to use the tomahawk. Explorers, colonists, soldiers, and sailors, trappers, and fur traders-all found it a useful tool and weapon. Military use of the axe in America, of course, dates back to the Vikings, who favored it as a weapon, and even one mass murder of five women by an axe-wielding Viking on American soil is recorded in the Norse sagas. Spanish soldiers of the early I6th century also carried battle axes through the southern states. ${ }^{49}$

When the English and Dutch colonists arrived in the next century, the tradition of the axe as a military weapon had become obsolete in their native lands. Yet, in I64I, colonial governor William Kieft directed that Negroes in New Amsterdam were to be armed with "small axes" and half-pikes to aid in the war against the Indians. Soldiers, on the other hand, were normally armed with a gun and a sword. Experiences here, however, soon demonstrated that the hatchet was in many ways a more useful weapon to carry on expeditions into the wilderness than the sword, for it could serve utilitarian purposes as well. At first it was decided that a certain number of men in each unit would exchange their swords for hatchets as, for instance, the decree of the Council of Connecticut Colony in I675: "It is ordered that ten good serviceable hatchets be provided in each county for the use of the army, and ten soldiers to carry them instead of swords." Before the end of the century, militia laws almost universally specified that either a sword or a hatchet would be acceptable for military purposes. Since militiamen had to provide their own weapons, there was an understandable tendency to select the hatchet, which was cheaper than the sword, and which could also be used around the house when not needed for military service. ${ }^{50}$

49 Olson, op. cit., 64. Garcilaso de la Vega, op. cit., passim.

50 Extracts from the Papers of Director Kieft, O'Callaghan op. cit., I, 4I4. Charles J. Hoadly (ed.), The Public Records of the Colony of Connecticut, I 5 vols. (Hartford, I850-I890), II, 385. Harold L. Peterson, Arms and Armor in Colonial America (Harrisburg, Pa., I956), 87, 88, 99, 257, 279 . 293-297, 300, 329. 
The 18 th century brought some modifications to this trend in military regulations, but did not change it materially until the Revolutionary War. Militia laws began to specify bayonets as well as swords or tomahawks. Then the swords began to disappear from the lists, leaving only the bayonet and tomahawk, which were sometimes carried in a double frog on a shoulder belt. For a time in I776, Virginia even directed its cavalry to carry tomahawks. During the Revolutionary War regular infantry generally abandoned the hatchet, but light infantry and riflemen who did not have bayonets continued to carry tomahawks throughout the conflict. ${ }^{51}$

The American colonials were not alone in their use of tomahawks in warfare. In I747, French troops and their Indian allies who attacked Fort Clinton in New York were instructed to fire a volley and then charge, axe in hand. The British light infantry adopted the tomahawk in I759, carrying it in a rough, buttoned case, hung in a frog on the left side of the belt, between the coat and waistcoat. This tomahawk became a standard part of the British light infantry equipment and was carried by them throughout the Revolution. ${ }^{52}$

Following the Revolution, riflemen in the American Army continued to carry tomahawks. In I793 the quantities of tomahawks in various arsenals were listed: ${ }^{53}$

$$
\begin{aligned}
& \text { West Point } \\
& \text { Philadelphia } \\
& \text { Carlisle, Pa. }
\end{aligned}
$$

Ft. Washington, Western territory

$$
\begin{aligned}
& 45 \\
& 6 \\
& \text { I007 with handles } \\
& \text { IOI9 without handles }
\end{aligned}
$$

$$
236
$$

Compared with other arms available, this was an impressive inventory. As late as I8I9 there were still I074 of these tomahawks at Carlisle Barracks. ${ }^{54}$

When the Lewis and Clark expedition of I804-I806 was dispatched to explore the newly-acquired Louisiana Territory from St. Louis to the Pacific, soldiers carried tomahawks believed to

51 Peterson, op. cit., 257, 279, 293-297, 300, 333, 334, 335 .

52 O'Callaghan, op. cit., X, 79, 80. Peterson, op. cit., 296. Woodward, op. cit., 30, 32. Charles M. Lefferts, Uniforms of the American, British, French and German Armies in the War of the American Revolution (N.Y., I926), I95, I96. Cecil C. P. Lawson, A History of the Uniforms of the British Army, 3 vols. (London, I940-I960), II, 47.

53 Records of the Office of the Chief of Ordnance, War Records Division, National Archives. Walter Lowrie and Matthew Clarke, (eds.), American State Papers, Military Affairs (Wash., D.C., I832), I, 44.

54 Ibid. 
have been made in the national armory at Harpers Ferry. At this time there were no regular riflemen in the American Army, such troops having been discontinued with the abandonment of the Legion system in 1796 . But when riflemen were reintroduced in I808, they were again issued tomahawks and tomahawk belts, which they continued to use throughout the War of I8I2. Following the war, special units of riflemen were again discontinued, and with them the tomahawk disappeared from the army as a regulation weapon, though the hatchet still continues to be issued as a tool to the present day. ${ }^{55}$

In the civilian world, hatchets or tomahawks were long carried by traders, trappers, explorers, and frontiersmen. This continued well into the Igth century, when the trapper, Osborne Russell, noted that his companions frequently carried hatchets fastened to the pommels of their saddles. Leaders of wagon trains following the Santa Fé trail in the I840's advised each man in the companies to provide himself with a tomahawk. Still later, the professional buffalo hunters clung to their hatchets just as they did to their knives and rifles. ${ }^{56}$

For the most part, the tomahawks carried by both soldiers and civilians were the typical simple hatchet or belt axe of the period. Hordes of hatchet heads from such military sites as Fort Ticonderoga reveal clearly the type carried by both militiaman and regular (see Nos. 35, 36 and 37). All varieties are there, from the polless European styles through American implements with welldeveloped polls and ears. There are also documented specimens of spiked axes and hammer axes known to have been used by whites, in such collections as Fort Ticonderoga, the Rhode Island Historical Society, and Washington's Headquarters at Newburgh, New York. In the United States National Museum there is a hammer axe presented to Davy Crockett by the young men of Philadelphia. And there are other hammer specimens bearing U. S. marks, indicating official issue. There are no extant specifications covering the tomahawks issued to United States riflemen at any period, and it may well be that some of these were either spiked or hammer axes. In the Henry Ford Museum collection there is a unique tomahawk bearing a splendidly forged eagle head on its poll and the name "Jas. McTear," apparently the owner, engraved on it (see No. 304).

$55 \mathrm{H}$. Charles McBarron, Jr., "American Military Dress in the War of I8I2, Part IV, Regular Riflemen," Military Affairs, V, No. 2 (Summer I94I), I38-I44. Woodward, op. cit., 32.

56 Osborne Russell, op. cit., 82. S. A. Clark, Pioneer Days of Oregon (Portland, I905), I, 216, 2I7. Carl Russell, MS. cit. 
Although it has long been thought that the pipe tomahawks were strictly for Indian use, this is not entirely true. In the Museum of the American Indian there is a specimen bearing inscriptions which would indicate it was owned by a colonial soldier (see No. 30I). In the Caldwell collection is a more elaborate pipe tomahawk of the I800-I8I5 period, inlaid in gold and silver, and engraved with an eagle and military trophies (see No. 303). This is engraved "American Horse" along the edge, and would seem to be intended for white use, as were swords of approximately the same period inscribed "American Light Horse," most of which were associated with the Pennsylvania area. Aside from these and other specimens of the pipe axe which appear to have been owned by non-Indians, there are persistent accounts suggesting that the white frontiersman and soldier frequently enjoyed the combination of weapon, tool, and pipe in one implement, and sometimes even split the haft and chewed the wood to obtain the tobacco flavor when the supply became exhausted.

Several tomahawks and hatchets, which seem clearly to have been owned by whites, or issued to troops, are described in detail in captions Nos. 300-3I4; but it will be seen from the above comments that almost any of the types described in previous sections (except perhaps the decadent brass, pewter, and stone varieties) could also have been carried by the colonist or frontiersman, as well as by the Indian. 


\section{CHAPTER XII}

\section{NAVAL BOARDING AXES}

$\mathrm{F}$ or centuries the sailor looked upon the hatchet as an essential tool and weapon and used it in much the same ways as a soldier did. On sailing ships the rigging frequently became tangled as masts or arms were shattered in battle, and ropes had to be cut quickly to clear out débris. The hatchet was the obvious answer. Such naval battles also frequently ended as the vessels came together and the crew from one boarded the other to finish the action in hand-to-hand fighting. Here the hatchet, or boarding axe as it was usually called, was especially important. Nets or other obstructions were frequently raised to hinder any such boarding attempt, and these had to be cut and cleared away with the axe, which then became a weapon in the fighting that followed. Landing parties also normally carried such axes as a tool or defensive weapon for use in any emergency they might encounter.

Little is known about the naval boarding axes of the $I 7$ th and early I8th centuries, but by the late I8th century established patterns had developed which seem to have been based on long tradition. The spiked axe was almost universal, and there were iron straps either forged as part of the head or passing through the eye, which ran back along the haft to protect it against cuts and to add strength. On British and American boarding axes these straps were normally on the sides; on French specimens they were often along the top and bottom. During the Igth century British and American axes usually had notches cut in the back of the blade above the heel for use in snaring lines or gripping gunwales or, in later types, as nail-pullers. Aboard ship, boarding axes were kept in racks, issued as need arose, then returned to the racks. Some few were provided with belt hooks (notably by the French), but this does not seem to have been the practice either in Great Britain or the United States.

About the time of the Civil War, the United States abandoned the spiked axe in favor of one with a hammer head and, at the same time, adopted a leather frog with a button-over strap, so that it could be carried securely on the waist belt. During the Civil War, boarding axes were issued to specified crew members, but these soon ceased to be a weapon as naval tactics changed with 
the introduction of steam ships and long range cannon. Boarding actions were no longer practical and wooden masts and rope rigging also disappeared. The boarding axe of the late Igth century was an anachronism, useful only for emergencies, and, as such, soon became relegated to the tool box. ${ }^{57}$

These statements concerning the evolution of the boarding axe in the United States Navy have necessarily been general and somewhat vague, for such axes were not covered in regulations. In the early years of the new nation, contracts were usually let for the outfitting of a specific ship, but the language in these agreements stated only that the axes were to be made according to a pattern which was to be supplied to the contractor. This pattern has long since vanished. Thus, it is known, for instance, that, in I797, the Constitution and the Constellation each received roo boarding axes, and it is also a matter of record that, in I8I6, various contractors from Massachusetts to Virginia were offering to supply such axes at prices ranging from $62 \frac{1}{2}$ cents to $\$ 7.00$ each. But it is impossible to determine the exact pattern in any given case. Dated specimens and collateral evidence supply the principal data, and though the outlines are clear, the details are missing. ${ }^{58}$

${ }^{57}$ Ordnance Instructions for the U.S. Navy, 4th edition (Wash., D.C., I866), Part I, r9-25.

${ }^{58}$ Naval Records Division, National Archives. 


\section{DIRECTORY OF MAKERS AND DEALERS}

Albot, Joseph Address unknown. Employed by the British to make and repair axes for friendly tribes, I755-I763.

Allere, J. B. Chicago. Known to have made pipe tomahawks ca. I820-I 840 .

Ancram \& Co. England. Supplied iron mongery and cutlery to the Hudson's Bay Company in I8oo.

Andrus, John Address unknown, probably New York. This name appears on the pipe tomahawk presented to Cornplanter now in the New York State Museum, Albany.

Bagg, John England. Supplier of trade goods, I706.

Bailey, Thomas \& Company England. Suppliers to the Hudson's Bay Company, I794-I8Io.

Ballard, Etienne Blacksmith at Detroit, I778.

Bell \& Company England. Suppliers to the Hudson's Bay Company, I792.

Bordeau, John Fort Laramie, Dakota Territory. Blacksmith and ferryman at the Fort before and after I847, Bordeau made hatchets without steel edges from old wagon tires, which he traded to the Indians for Io beaver skins. His mark was JB.

Bowen, Ryar Address unknown. Blacksmith hired to make and repair hatchets for Indians friendly to the British during the French and Indian War.

Bowen, William Address unknown. Made and repaired axes in I770.

Brown, Elijah Richmond, Virginia. In I8I6 he offered to make "battle axes" for the Navy at $\$ 2.50$ each.

Brown, J. M. Green Bay, Wisconsin. Known to have made pipe tomahawks ca. I820-I840.

Burgon, John

Burgon, John \& Son England. Supplier of trade goods as John Burgon, I793-I8II; as John Burgon \& Son, I8I2-I82I.

Burnett, William Green Bay, Wisconsin. Known to have made pipe axes, $c a$. I820-I830.

Cargill, Peter England. Supplier of trade goods, I76I-I78I.

Collins \& Company Collinsville, Connecticut. Established in I826 by Samuel W. Collins, Daniel C. Collins, and William Wells, this firm has been primarily manufacturers of axes, ploughs, and machetes. Collins axes were designed as tools, not 
specifically for the Indian trade, but a number of them found their way into Indian hands. See No. 45. Although the factory was at Collinsville, the address "Hartford" was stamped on all Collins products.

Conin, Peter Address unknown. Made and repaired hatchets for the Indian allies of the British during the French and Indian War.

Cremar, Peter Address unknown. Made and repaired hatchets for the Indian allies of the British and Americans during the French and Indian War.

Growley-Hallett \& Company England. Suppliers to the Hudson's Bay Company, I748-I75I.

Crump, Thomas England. Supplier to the Hudson's Bay Company, I742-I760.

Dana, Daniel Canton, Massachusetts. In I8I6 he, Adam Kinsley and Charles S. Leonard offered to make boarding axes for the Navy at $\$ 7.00$ each.

Deringer, Henry 370 N. Front Street, Philadelphia. Famous firearms maker, born I786 in Easton, Pa. He worked first in Richmond and moved to Philadelphia in 1806 , working there until his death in I868. In I8I6 he made 5 I brass pipe tomahawks for the Office of Indian Trade for $\$ 2.50$ each.

Dimick, Horace E. St. Louis, Missouri. In I849 Dimick moved to St. Louis from Lexington, Kentucky where he had operated a cabinetmaking and upholstery shop. He opened a gunsmithing and sporting goods business at $38 \mathrm{~N}$. Main Street, under the name of H. E. Dimick \& Co. In I86I he opened another store at 97 N. 4 th Street. His specialty was fine target rifles and pistols, but his stock was varied, including tomahawks and bowie knives as well as all manner of firearms. Some of these were made in his own shop; others were purchased from different manufacturers. He died in I873. See No. I53.

Duplesis, Louis Blacksmith at Oviatenon, Indiana, I778.

Durant, J. Address unknown, probably American. The name appears on a hatchet head of the I8th century found in New Hampshire.

Dyelle, François Blacksmith among the Miami, I778.

Gosling, Richard Philadelphia. Made knives and belt axes, I7I4-I7I7.

Goulding \& Company New York City. Makers of surgical instruments and fine cutlery, ca. I850-I860. See No. 60.

Gove, Carlos Council Bluffs, Iowa; St. Joseph, Missouri, and Denver, Colorado. Gove was born in Wentworth, New 
Hampshire in I8I7 and learned the gunsmith trade in Boston. After a tour with the dragoons, he became gunsmith at the Pottowattomie Agency near Council Bluffs in I840. Four years later he moved to St. Joseph and established his own business. In 1854 he returned to Council Bluffs. In I862 he opened a gunshop at the corner of 16 th and Larimer Streets in Denver. By I87I he had moved to I2 Blake Street. In the early I880's the firm became C. Gove \& Son; the elder Gove died in I90o. See Nos. I44 and I47.

Graham, Buxton \& Company England. Suppliers to the Hudson's Bay Company, I8I8-I820.

Greaves, William \& Sons Sheaf Works, Sheffield, England. The name appears on a tomahawk of about I830-I850 with a threaded diamond-shaped point which may be unscrewed. Presumably a pipe bowl could be substituted, but this is now missing.

Hall, William A. Chicago. Made pipe axes, ca. I820-I840.

Hammond Philadelphia. The name and city are stamped on a simple hatchet with thickened poll and ears of the late 18 th or early Igth century.

Harrison \& Bagshaw England. Suppliers to the Hudson's Bay Company, I753.

Hendricks, John Philadelphia. Made belt knives and trade tomahawks, I783-I79o.

Hoff, F. Lancaster County, Pennsylvania, I800-I8I5. Listed as a blacksmith, his name appears on the superb pipe tomahawk, No. 303 .

Hoffman, Fred Philadelphia. In I806 he offered to make navy boarding axes for $\$ I$.oo each.

Hoglan, Isaac Georgetown, D. C. In I8I6 he offered to make "battle axes" for the Navy at $95 \notin$ each and boarding axes at $75 \notin$ each.

Holtzappfel \& Co. England. Supplied axes to the Hudson's Bay Company in I8II. A pipe tomahawk bearing the name and the British ordnance mark of the broad arrow and letters BO is in the collections of the Museum of the American Indian. See No. I26.

Horstmann Philadelphia. The firm was founded by W. H. Horstmann in I8I8 as a lace and fringe factory. Between I828 and I830 he opened military goods stores in Philadelphia and New York. He took his sons into the business, and from I843 until I 858 the Philadelphia directories list W. H. Horstmann \& Co. and W. H. Horstmann \& Sons at the same address, $5 \mathrm{I}$ N. 3 rd Street. From I845 until I849 the New York firm operated 
under the name of Horstmann, Sons \& Drucker. In I858 the elder Horstmann died, and in I 859 the Philadelphia directory lists Horstmann Brothers \& Co. in partnership with John G. Franklin at 723 Chestnut St. The company was primarily a sales concern, contracting for finished items from various manufacturers in this country and abroad. The firm is still in business. See No. $23 I$.

Hunt, James England. Supplier of trade goods, I806.

IS Rutland, Vermont. These letters in a heart-shaped cartouche appear on a spiked axe of the mid-I8th century along with the stamped word "Rutland," the date I775 and the number 3 .

JB Mark of John Bordeau, q. v.

J. G. Unidentified mark on a spiked tomahawk from central New York State.

Johnson, Reynaldo Address unknown. In 1808 he delivered I7 8 half axes at $50 \notin$ each and 22 tomahawks at $40 \notin$ each to the Office of Indian Trade.

Johnson, Sam Washington, D. C. In I8I6 he offered to make "battle axes" for the Navy at $62 \frac{1}{2} \phi$ each.

Jourdain, Joseph Wisconsin. Born at Three Rivers, Canada, in I780. He moved to Green Bay, Wisconsin in I796 and worked at the agency there until I834. In that year he was transferred to Winnebago Rapids near the Little Lake des Morts, where he lived until his death in I866. See No. I62.

Jukes, William \& George England. Suppliers to the Hudson's Bay Company, I748.

Kinsley, Adam Bridgewater and Canton, Massachusetts. In I8I6, in partnership with Daniel Dana and Charles S. Leonard, he offered to make boarding axes for the Navy at $\$ 7.00$ each. Kinsley was also a gunsmith who had federal contracts for muskets in 1798 and $\mathrm{I} 808$.

Koch, Rudolph Fort Michilimackinac. A blacksmith at the post before and after I769, when he rendered a bill to Sir William Johnson for making and repairing hatchets and axes of all kinds, including pipe tomahawks.

Lafoy or Lefoi, Agustin Detroit. Assistant blacksmith at Detroit, I778, and apparently active there as late as I820.

Leonard, Charles S. Canton, Massachusetts. In partnership with Daniel Dana and Adam Kinsley, he offered to make boarding axes for the Navy at $\$ 7.00$ each in $\mathrm{I} 8 \mathrm{I} 6$.

Lewis, John Detroit. Made pipe tomahawks, ca. I820-I840.

Lloyd, Nicodemus Address unknown. In 1805 he made I2 pipe tomahawks and 61 wood axes for the Office of Indian Trade. 
In I806 he made Ioo "wood axes," I50 "common tomahawks," and 50 "pipe tomahawks."

Lusignant, F. Fort Wayne, Indiana. Made pipe tomahawks ca. I820-I840.

Margnier Prairie du Chien, Wisconsin. A French smith mentioned as making pipe tomahawks early in the I9th century.

Migneron, Solomon Address unknown. Made pipe tomahawks, ca. I820-I840.

Montour Prairie du Chien, Wisconsin. French smith mentioned as making pipe tomahawks early in the Ig th century.

Morton \& Company England. Suppliers to the Hudson's Bay Company, I8I4.

Opy, William Address unknown. Employed by the British to make and repair hatchets for their Indian allies during the French and Indian War.

Parke The name appears on a pipe tomahawk of the second half of the I8th century, which also bears the British broad arrow. This may possibly be William Parkes, q. v. See No. II3.

Parkes, William England. Supplier to the Hudson's Bay Company, I770-I790.

Parkes \& Company England. Suppliers to the Hudson's Bay Company, I79I-I800.

Parkes \& Hearle England. Suppliers to the Hudson's Bay Company, I803.

Pettibone, Daniel Philadelphia. Gunsmith, cutler, and U. S. inspector of arms, I808-I809. During the War of I8I2 he made belt axes as well as pikes and knives.

Printup, William Address unknown. Made and repaired hatchets for Indians friendly to the British during the French and Indian War.

Provinsalle, Pierre Saginaw, Michigan. Made pipe tomahawks, ca. I820-I840.

Putnam, Ernestus Address unknown. In I8I8 he delivered 300 squaw axes to the Office of Indian Trade.

Rose, J. \& Son New York City. In I 806 he made 36 tomahawks for the Office of Indian Trade at prices ranging from 50 to 90 cents each.

Russe11, George England. Listed as supplier of trade cutlery and hardware, I800-I8I6.

Russell, Michael England. Supplier to the Hudson's Bay Company, I804.

Russe11, William England. Supplier of trade goods, I8I7-I820.

Russell \& Company England. Listed as suppliers of trade goods, I792. 
Russell \& Smith England. Suppliers of trade goods, I789.

Sanderson \& Company England. Supplier of trade cutlery and hardware, I744.

Sanderson \& Towers England. Listed as supplier of trade goods, I745-I747.

Seyfert Philadelphia. The name and city appear on a spiked tomahawk of the late 18 th or early I9th century.

Sharp, Catherine England. Supplier to the Hudson's Bay Company, I784.

Sharp, James England. Supplier to the Hudson's Bay Company, I760-I790.

Shaw, Lemuel Address unknown. In I8II he made I2 "Large squaw axes" at $56 \notin$ each for the Office of Indian Trade.

Smith, William England. Supplied hardware and cutlery for the Indian trade, I8I5.

Southouse \& Chapman England. Suppliers to the Hudson's Bay Company, I746-I752.

Southouse, Samuel \& Company England. Suppliers to the Hudson's Bay Company, I738-I756.

Sprague, O. B. Probably English, ca. I820-I850. See No. I75.

St. Cyr, Levi Winnebago, Nebraska, Born about I875. A nickelplated tomahawk bearing his name and date is known. See No. 233. Another tomahawk obviously by the same hand but unmarked is illustrated as No. 234.

Stanton Edward England. Supplier of Indian trade goods, I75I-I760.

Stowe, A. J. Address unknown, probably American. The name appears on a belt axe of the I8th century found in Vermont.

Taylor, William England. Supplier to the Hudson's Bay Company, I737-I74I.

Taylor \& Company England. Supplier to the Hudson's Bay Company, I79o.

Thomas, J. \& C. Probably England. The name appears on a pipe tomahawk made ca. I80o. See No. I28.

Trott, J. England. Supplier of hardware and cutlery for the Indian trade, I790.

Van Eps, John B. Probably New York. Made Ioo axes for the Treaty of Burnet's Field in I770 at a cost of 4 shillings each.

Watson, J. Address unknown. The name appears on an iron pipe tomahawk of about I80o in the collection of the Ohio Historical Society.

Welshhans, J. York, Pennsylvania. There were four gunsmiths in York, Pa. who signed their work $J$. Welshans or $J$. Welshhans, from the I770's through the early Igth century. Two were 
named Jacob, two Joseph, and it is impossible to determine which is which from the signature. For a fine brass tomahawk with a steel edge bearing this name. See No. $2 I_{3}$.

W. H. \& Co. A belt axe bearing this stamp was found at Fort Ticonderoga.

Wheat, Thomas Washington, D. C. In I8I7 he delivered to the Office of Indian Trade 66 large squaw axes at $75 \phi$ each, 67 middle squaw axes at $62 \frac{1}{2} \notin$ each, and 62 small squaw axes at $50 \notin$ each.

Whitford, John England. Hardware and cutlery supplier, I809.

Wilson, Samuel

Wilson, Samuel \& Son

Wilson, Simon \& William

Wilson, William England. Supplied hardware and cutlery for the Indian trade, I737-I745. Changes to Samuel Wilson \& Son, I746-I760; Simon \& William Wilson, I76I-I767; and William Wilson, I768-I790.

Wilson, C. \& Company England. Suppliers of hardware and cutlery, I8I6.

Wood, B. Probably English. A late I 8 th-early I9th century pipe tomahawk of iron bearing his name, is in the collection of the Museum of the American Indian. See No. I27.

Woodruff, W. A. Probably Cincinnati. A silver or silver-plated tomahawk bearing his name and the date 1850 is illustrated as No. 256 . 


\section{INDEX TO PROVENIENCE}

Attributions, as recorded in captions, are given below by tribe or, if that is not known, by geographical area or state. Numbers correspond to illustrations.

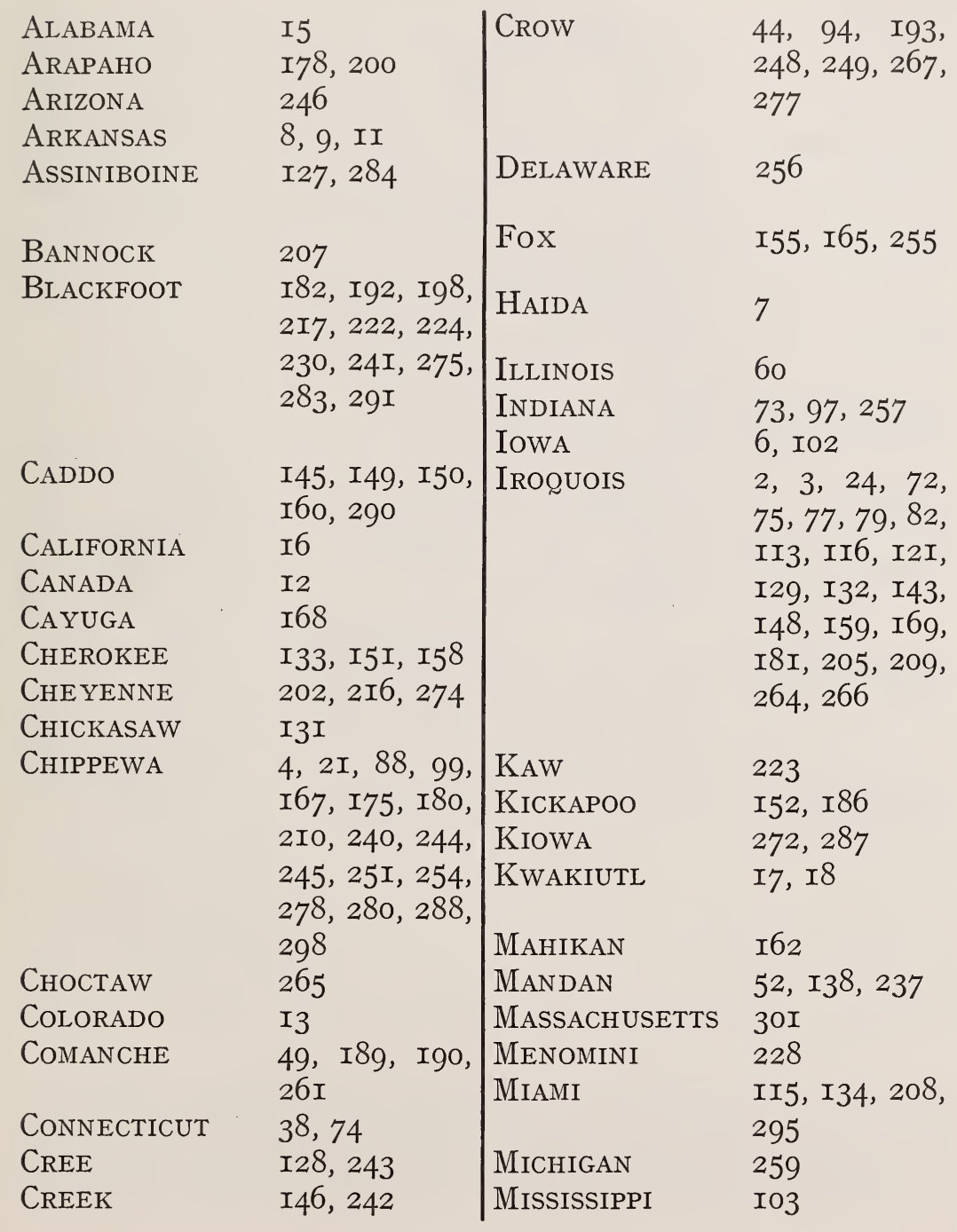




\begin{tabular}{|c|c|c|c|}
\hline $\begin{array}{l}\text { NEBRASKA } \\
\text { NEW ENGLAND }\end{array}$ & $\begin{array}{l}204 \\
54,56,59,89 \\
90\end{array}$ & SHAWNEE & $\begin{array}{l}\text { II9, I } 20, \text { I } 35, \\
\text { I36, I } 37, \text { I } 55, \\
\text { I85, } 226\end{array}$ \\
\hline NEW HAMPSHIRE & 34 & SHOSHONI & I00, I6I, I97 \\
\hline NEW JERsEy & $3 I 0$ & SIOUX & $2 I, 22,23,42$, \\
\hline New MeXICO & 39 & & $43,45,48,80$, \\
\hline NEW YORK & $\begin{array}{l}35,36,37,57 \\
62,63,64,65, \\
66,67,69,90, \\
92\end{array}$ & & $\begin{array}{l}\text { 93, 95, I25, } \\
\text { I26, I30, I66, } \\
\text { I74, I76, I79, } \\
\text { I84, I87, I9I, }\end{array}$ \\
\hline NEZ PERcÉ & $\begin{array}{l}\text { I53, I70, } 2 \text { I } 8, \\
220,268,279, \\
299\end{array}$ & & $\begin{array}{l}\text { I94, I95, I96, } \\
\text { I99, 20I, 227, } \\
236,247,250 \text {, } \\
253,264,266,\end{array}$ \\
\hline $\begin{array}{l}\text { OKLAHOMA } \\
\text { OHIO }\end{array}$ & & & \\
\hline SAGE & $\begin{array}{l}260,142,221, \\
46,47,50,5 I\end{array}$ & SOUTHWEST & $\begin{array}{l}292,294,297 \\
\text { I08 }\end{array}$ \\
\hline $\mathrm{T}$ & 2 I9, 232, 269 & TENnESSEE & I4 \\
\hline OTTAWA & $5,180,229$ & TSIMSHIAN & 20 \\
\hline & 254 & TLINGIT & I9 \\
\hline PENNS YLVANIA & $\begin{array}{l}\text { 6I, } 76, \text { II } 2, \\
2 \mathrm{I} 3\end{array}$ & UTE & I77 \\
\hline Plains & I72, 282, 293 & & \\
\hline PONCA & I04 & VERMONT & 04,300 \\
\hline POTAWATOMI & $\begin{array}{l}\text { II4, I44, I47, } \\
\text { I64 }\end{array}$ & VIRGINIA & I, IOb, 206 \\
\hline SAUK AND FOX & II7, II8, I39, & $\begin{array}{l}\text { WAMPANOAG } \\
\text { WASHINGTON }\end{array}$ & $\begin{array}{l}23^{2} \\
309\end{array}$ \\
\hline & I40, I4I, I63, & WEST VIRGINIA & I23 \\
\hline & $\begin{array}{l}I 83,234,273 \\
276,28 I\end{array}$ & WINNEBAGO & $\begin{array}{l}\text { I56, } 233,239 \text {, } \\
263,296\end{array}$ \\
\hline SEMINOLE & I73 & WYANDOT & IOI, I57 \\
\hline
\end{tabular}


Appendix

THE BLACKSMITH SHOP

by

Milford G. Chandler

The pioneer blacksmith shop was a cluttered-up place where at one time the prevailing odor might be of wood smoke; at another time, it would be the smell of the half-rotted hoof and frog of a horse being prepared for shoeing. Following the sound of a hiss-ss-s as a hot horseshoe was applied, the pungent smell of burning hoof would fill the air. The ringing of the anvil could be heard throughout the village and, often, the loud whinnying of a stallion. Except for those sounds and an occasional dogfight, there generally was silence.

Thick dust covered all surfaces not worn clean from use, and out-of-the-way places were littered with odd pieces of iron and wood. To the rear was a heap of old iron, and inside, hanging from pegs, were a few bars of new iron of the sizes most needed. The shop was a cold place in winter, but in the summer, with the big door open, it was as airy and attractive as the barroom or the general store. Over the entrance might be a sign, "Blacksmith Shop." In later days this often read "Practical Horseshoeing" or "Scientific Horseshoeing," especially if there were rivals in the village.*

The iron used was called Swedish, Norway, or wrought (commonly pronounced "rot") iron. Very low in carbon content, it was soft and contained considerable quantities of slag and other impurities. These occurred in various forms, from fine streaks to large pockets or flaws filled with gritty material. When heated to welding temperature, this iron had the merit of being sticky, with the stringy fibrous appearance of pulled taffy.

Steel was expensive. It was made in the shop by drawing iron down to small bars, which were then heated to a high temperature for a number of hours in containers in the presence of charred leather or bone. During this time the white-hot iron absorbed

* In the British Isles and eastern North America the term forge was used to designate the business establishment where forgings were made. But later, in the West, the definition became more limited. Here, forge referred to the actual hearth where the work was heated for forging or welding, and the term blacksmith shop was a more popular name for the establishment. 
carbon from the charred granules. The bars were then welded together to form the sizes wanted. Naturally, the impurities already present in the iron were not eliminated and, with the addition of carbon, there was an even greater risk of imperfect welds. This was called "blister" steel because of such imperfections. The collector should look for these characteristics in the material of genuine forged tomahawks.

In those days, because iron bars were expensive and the range of sizes limited, a supply of scrap was an adjunct to a forge. Large pieces were made by welding smaller ones together. One forged tomahawk, therefore, might contain iron from a worn-out wagon wheel, another from a horseshoe, while a third blade might contain streaks of iron from any number of different sources, even from guns. The steel might have been retrieved from obsolete swords, bayonets, or from discarded files and rasps.

In the smaller establishments a variety of work was done, including the repair of wooden wagon parts and guns as well as horseshoeing. It is quite likely that a good share of tomahawks were made by gunsmiths and blacksmiths as a side line. For example, Jourdain, the best-known tomahawk maker in America, had a general blacksmith business.

The actual hearth or forge was a structure of brick with an elevated platform on which the fire was built. Partly over this was a hood, an extension of a chimney that rested on the end of the forge at the blacksmith's left. At the right end was a trough containing coal of the type we now call charcoal. This fuel was made locally from wood that had been heated until the gassy components were driven out.

Air was conveyed from a bellows, by pipe, to the base of the fire at what was called the tuyere, pronounced "tweer." The bellows was operated with the left hand by means of a lever. It usually had a hinged lower flat member for pumping the air, a stationary central partition, and a hinged upper member, with an accordion-like strip of flexible leather to connect the three together. This formed two compartments. When the lower one was dropped, the vacuum created opened a large flat valve to take in air. Then, when it was raised, the air was forced up through another flapper valve in the stationary member into the upper chamber, which expanded to accomodate the charge of air.

Some of the basic tools and heavy equipment required for tomahawk manufacture are illustrated in Figure 9. In the shop, tongs were hung on a convenient rack and, at the coal trough, there was a small shovel and poker. To the left was a tub of water called the slake, or "slak," tub and not far away was a hinge-type vise of 
wrought iron anchored to a bench. Because it was steadied by a projection going down to the floor, this was called a post vise. In front of the forge stood the anvil - a heavy forging of iron with a thick steel face welded to its top surface. This was mounted on a section of tree trunk to bring it to a convenient height. Handy to the anvil were the blacksmith's hammers, punches, and sledge as well as hot and cold chisels, fullers, and wooden-handled flatters. The use of the flatter required the coöperation of an assistant: while the blacksmith held the work with tongs and applied the flatter or other handled tools, his assistant struck with the sledge. The anvil supplied the backing or foundation for the various operations.

The iron was heated in the forge to a bright red color, and then worked on the anvil until it cooled to a dull red. It was reheated for each subsequent operation. Each time the smith would pump the bellows, sending a blast of air up through the fire to increase the intensity of the heat. Chisels were used to trim the work to shape; fullers were used to form grooves; and flatters, to level the surface marks made by the hammer. If a hatchet, hammer, or tomahawk was being made, a drift was also used.

Hammers and sledges were "faced" by welding a layer of steel to the iron work surface. For wood chisels and plane bits, a thin layer of steel was welded to one side of the tool to form the cutting edge. In the manufacture of hatchets, axes, and tomahawks, the steel or "bit" was usually welded into a slit made at the cutting end of the blade.

The most important aspect in this kind of forge welding was the smith's judgment of temperature, which he determined by watching closely the color of the metals as they were heated. The iron, when brought to near its melting point, became quite plastic. Particular caution was taken with the steel, however, for if it became too hot it would lose it properties of hardness. If the metals were overheated, they "spit," or threw off sparks, as oxidation occurred. As the two parts were heated, the areas to be joined were liberally fluxed. Borax was the flux preferred, but sand was also used. The flux served two purposes. First, acting as a cleaning agent, it formed a near-liquid paste that dissolved the surface oxides on the metals. This paste flowed easily from between the two parts when they were hammered together. It also formed a protective film over the metal surfaces, thus preventing the occurence of further oxidation from the hot blast of the fire. When each of the metals had simultaneously reached its proper temperature, the smith had to act quickly. The parts were removed from the fire, placed properly together on the anvil, and struck over the 


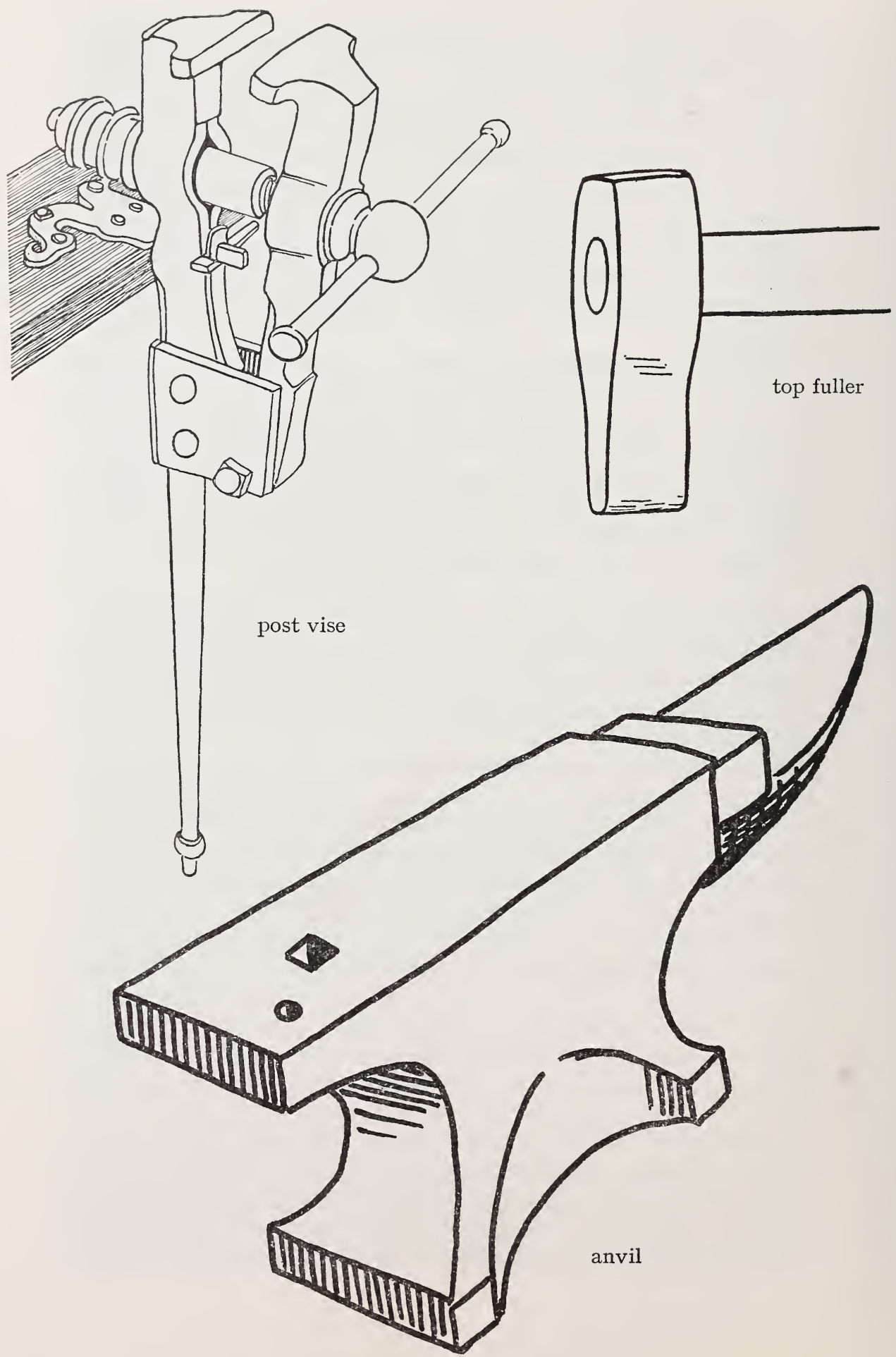

FIGURE 9. Basic tools and shop equipment 

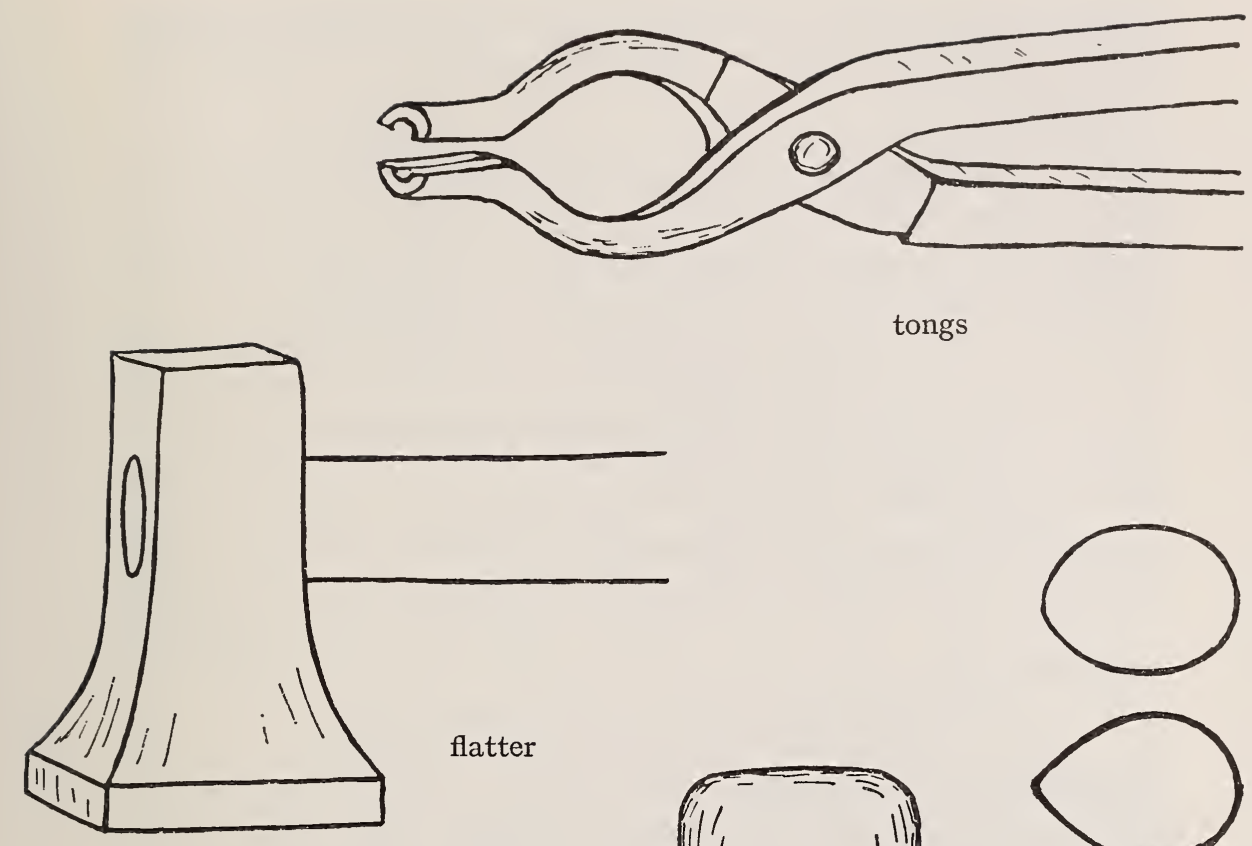

tongs
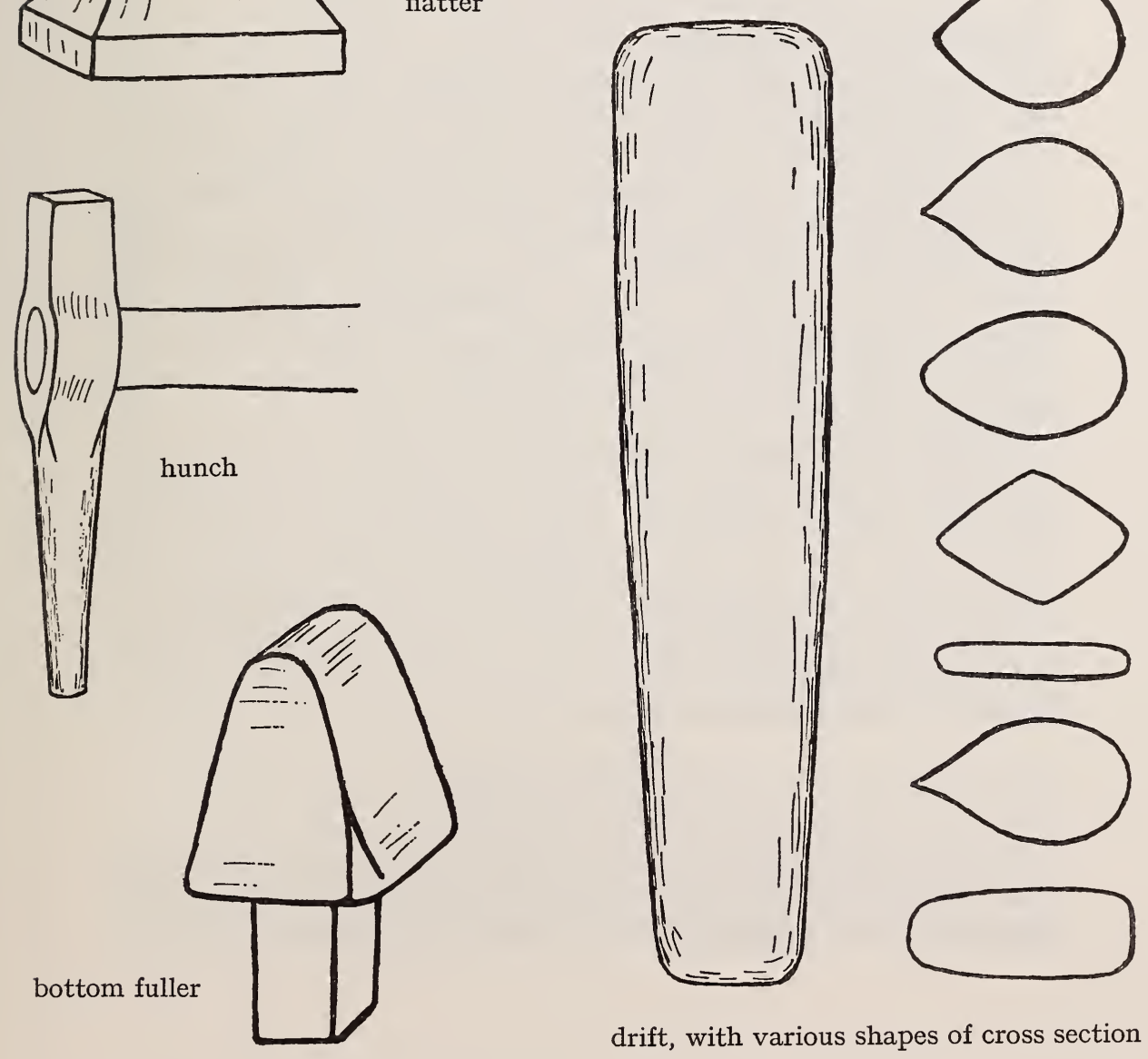

used in the manufacture of tomahawks. 
surfaces to be bonded. If, for any reason, the weld did not produce a good bond, it was called a "cold shut," and the entire process had to be repeated.

If the weld was successful, the projecting part of the steel was lightly worked over to reduce any brittle quality that might exist. The forging was heated again, put into the vise, and "hot filed." In this step the metal surface was gone over with a very coarse file or rasp, usually called a "bastard" file, to refine the form. If the work was a tomahawk, it was necessary to harden the cutting edge. To do this, the steel was again heated and then plunged into the water of the slake tub to cool. An extreme hardness - even brittleness - resulted in the steel, but the iron was not affected. Some risk was involved, for there was a chance that the steel might crack during the rapid chilling. Now, to impart toughness to the metal, it was tempered. The smith heated the iron body of the tomahawk just behind the cutting edge. The steel, which then appeared gray, was rubbed on the gritty floor. This abrasive action cleaned the surface of the metal so the smith was able to see the "color." As the heat traveled down the cutting edge, the metal slowly became a straw color, then purplish. When it turned a deep purple, the smith again quenched the blade in the slake tub. By this tempering process the steel edge was made tough enough as well as hard enough to stand service and retain its sharpness.

The forging was now ready for finish filing and polishing. In well-equipped shops these hard tasks were done by power-driven grinding stones and polishing wheels, but some hand filing was almost always required. If power polishing was done, care was taken to avoid excessive heating of the steel edge for this would cause a loss of temper and the metal would be softened. Following these steps, the tomahawk was ready for the user.

When a tomahawk rusted, the steel and iron usually took on different hues. Sometimes the iron rusted away so much that, at the front and back edges, the steel would stand at a slightly different level than the iron. If a tomahawk is the type used by Indians of woodland regions, it should show some sign of this steel cutting edge. A reproduction is not so likely to have this feature and is even less likely to have a body of "rot" iron into which a steel bit had been forge welded.

\section{CLASSIFICATION}

Because few tomahawks were marked with the maker's name, and because chronological information is so fragmentary, assignment of a specimen to a particular period hinges largely on 
technical points. One tool aiding in classification is the drift used to form the eye. The making of a drift took time and material and, unless he had a sufficient number of orders, it is quite unlikely that a maker would have had several on hand. More probably he would use only one for all the tomahawks he produced and merely change the external features to suit the requirements of his customers. The drift most commonly used for all types of tomahawks produced a near-oval shape in the eye. However, some smiths used an elliptical form while others preferred a modified rectangle. Several different cross sections of drifts are shown in Figure 9.

Another aid to classification is the technique of manufacture. A maker would most likely consider $h$ is particular method the proper way to do the job. The process is revealed principally in two places - the interior of the bowl and the inner surface of the eye. Points to be observed will be brought out in detail for each technique described here.

\section{TECHNIQUES OF MANUFACTURE}

The early tomahawk was almost always made by bending a strip of iron at the middle around a stake that was usually supported in the hole of the anvil. The two lapped ends were then welded together with a bit of steel enclosed at the working end. Most early examples show signs that the eye was "drifted out," truing it to receive the handle. Some tomahawks show where the smith neglected to true up the eye, possibly because the maker may not have had a drift on hand.

By improvising on this basic method, the makers could also produce several types of pipe tomahawks (see Figures Io and II). One such method to cut a dovetail into the top of the eye of the axe and drill or punch a hole through the eye. A short tube, often a section of gun barrel, was forged to a shank, leaving a bowl at one end and a flange at the other. This flange was then fitted into the dovetail and secured by brazing.

Another method was to fit the flanged tube like a saddle to the top of the eye and braze it into place. Still another obvious and easy way was to use a brass pipe bowl with a threaded cast iron stud at its base. This merely had to be screwed into a threaded hole drilled into the top of the axe eye.

In some instances, instead of using the brass bowl and iron stud combination, iron bowls were necked down and threaded. The brass screwed-in bowls did not meet with much success for they were subject to breakage at the stud and were easily screwed out and lost. The all-iron bowls were found to be somewhat more 
62

AMERICAN INDIAN TOMAHAWKS<smiles>c1ccccc1</smiles>

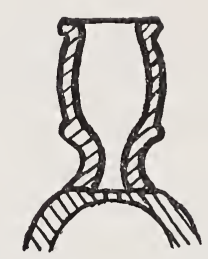

A. bowl, dovetailed
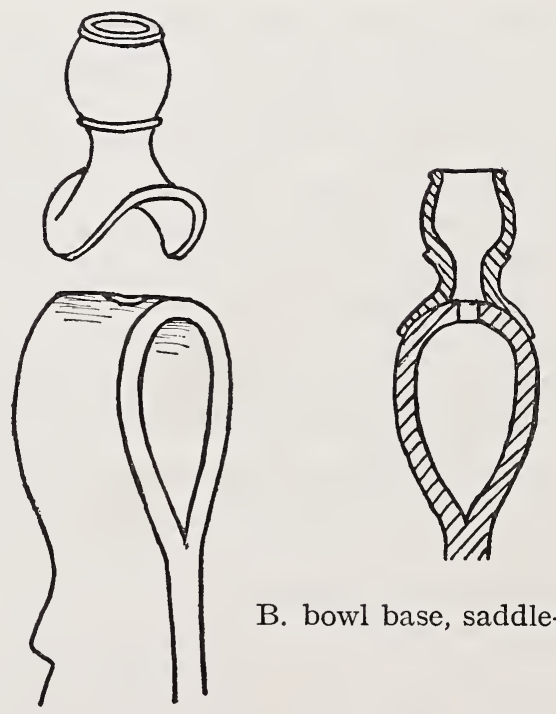

B. bowl base, saddle-shaped

FIGURE IO. Improvisations. 
durable. These are often hard for a collector to detect, but traces of the end of the stud can usually be seen inside the eye.

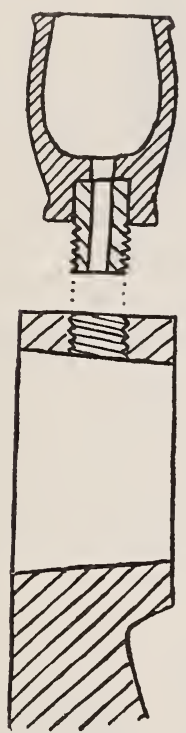

A. bowl with cast-in stud

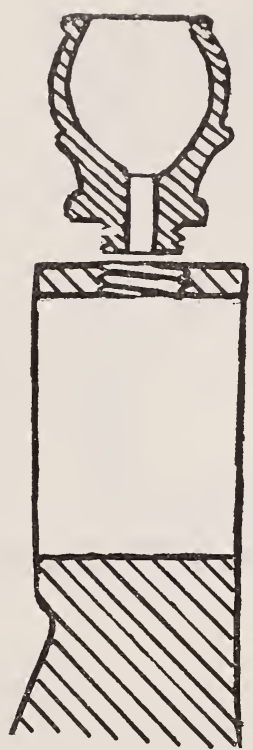

B. bowl made of one piece of iron

FIGURE II. Improvisations.

One improvisation which is likely to pass unnoticed is illustrated in Figure I2. In this instance, a pocket was forged in the top of the eye and a section of tube was welded into the pocket. The tube was then necked down and finished to form the pipe bowl. Often the weld is so perfect that there is no exterior evidence of a joint.

\section{Common Pipe Tomahawe}

None of the improvisations described above met with any great approval; it became apparent that a rugged, completely forged pipe tomahawk could be sold in quantities great enough to warrant its development. Most popular was a design based on the traditional axe of the wrap-around construction (see Figure I3). This had a stud or shank riveted and welded into the top of the eye. Because it is found in comparatively great numbers, this form is called the "common" type. Variations on this same technique suggest that several contractors had been engaged in producing it 


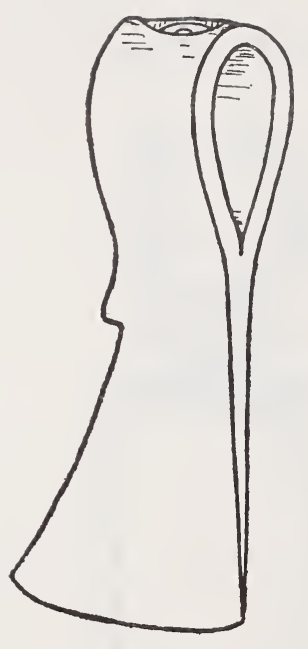

A. blade with forged pocket

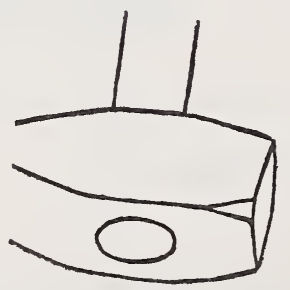

C. tube forced into eye

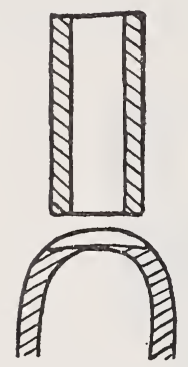

B. tube ready for welding

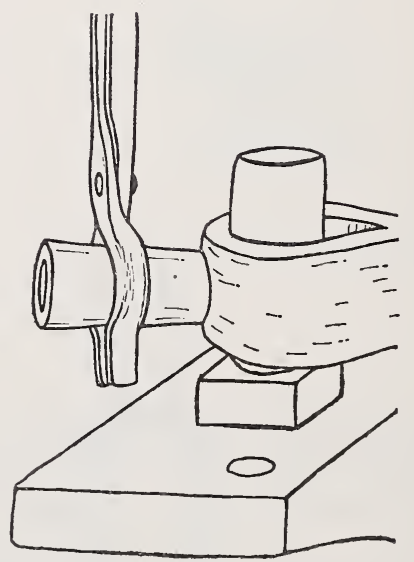

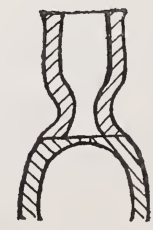

D. section of finished work

FIGURE I2. Improvisations: bowl welded into depression. 
to rather loose specifications, probably from samples. Surviving specimens also frequently show evidence of alterations made after manufacture.

Lathes of a sort were used to turn the bowls and tool marks can still be seen on well-preserved examples. Some give evidence that the blade had been ground on the flat surface to reduce the amount of hand filing. The contours of the shank, bowl, and eye, made by turning and filing, are pleasing and quite uniform from one specimen to another, again an indication that tomahawks of this type were made to specification.

Features that distinguish this method of manufacture are: the flat bottom in the bowl cavity; the faint trace, inside the eye, of the welded-in shank; and the seam where the eye ends and the blade starts, which can also be seen inside the eye.

Whatever the shape of the drift used to form the eye, it was customary, when making a pipe tomahawk, to line the eye with buckskin to seal and cushion its fit to the handle and thus prevent leakage.

\section{The "Pierced Eye" Method}

This technique (see Figure I5) was developed at an early date. For it, the smith required a short rectangular bar of iron, the end of which was formed into a pipe bowl. This was done by "upsetting," i.e., beating the end of the iron to increase its diameter. This section was then somewhat necked down by using the fuller and a chisel to form a groove behind the enlarged portion. The result was a dished-out pancake of metal standing on the end of the bar. This disc was then drawn down over a stake supported in the square hole of the anvil. A cross-pein hammer was used in the manner similar to that employed by the silversmith in forming cup-shaped pieces from sheets of silver. The blade was roughly forged down from the other end of the bar and slit to receive the steel bit.

The next step was to pierce the eye. A punch was driven nearly halfway into one side of the still-thick portion of iron in line with the thin edge of the blade. Then, from the opposite side, it was driven all the way through. A drift was inserted into this hole to stretch and form the eye. Since the drift tapered, the hole also had a taper, and the handle was similarly designed where it fitted the eye. This was advantageous for, by having the handle larger at the end away from the mouthpiece, the tomahawk head was prevented from coming off accidentally.

After the eye had been shaped, the blade was forged out to its full width and leveled off with the flatter. The shank between the 

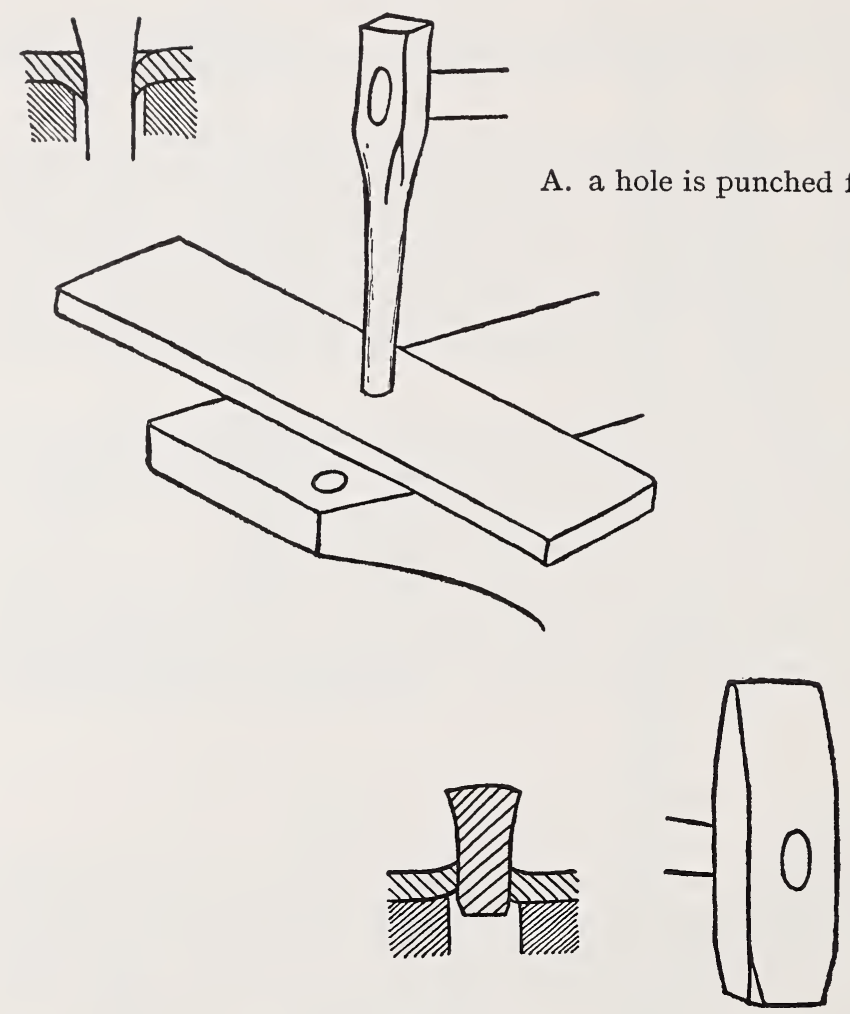

B. the shank is driven into the hole
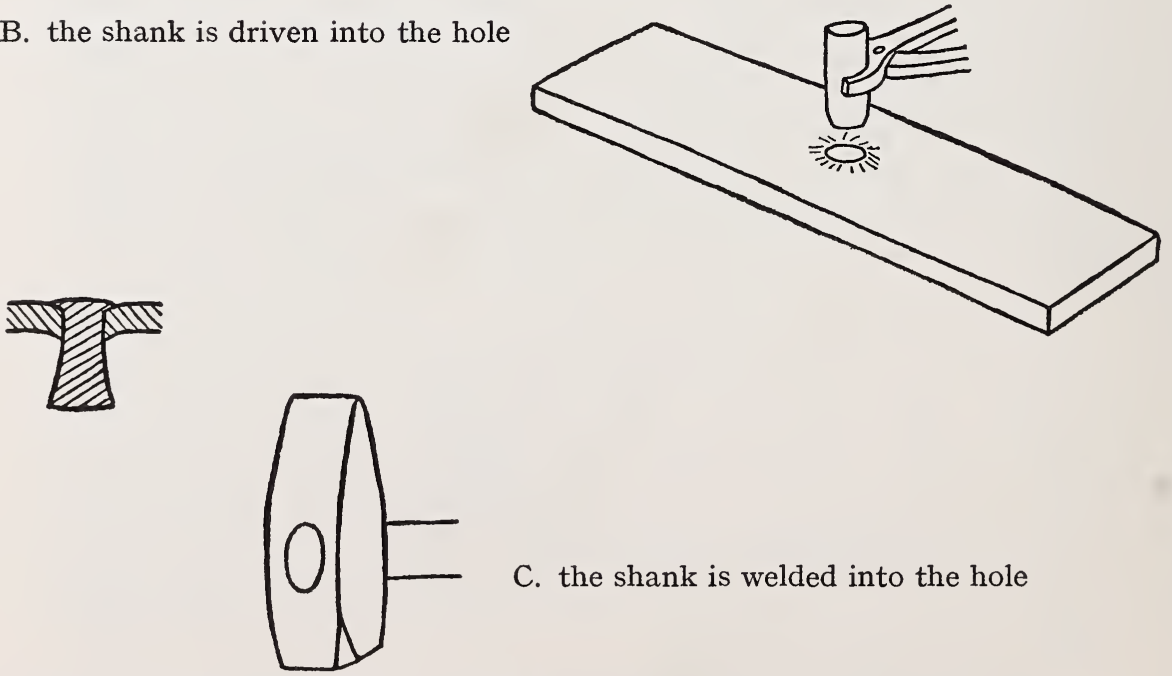

C. the shank is welded into the hole

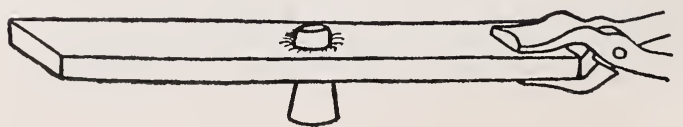

Figure I3. Manufacture of the 
D. the strip is bent and then welded over the steel insert
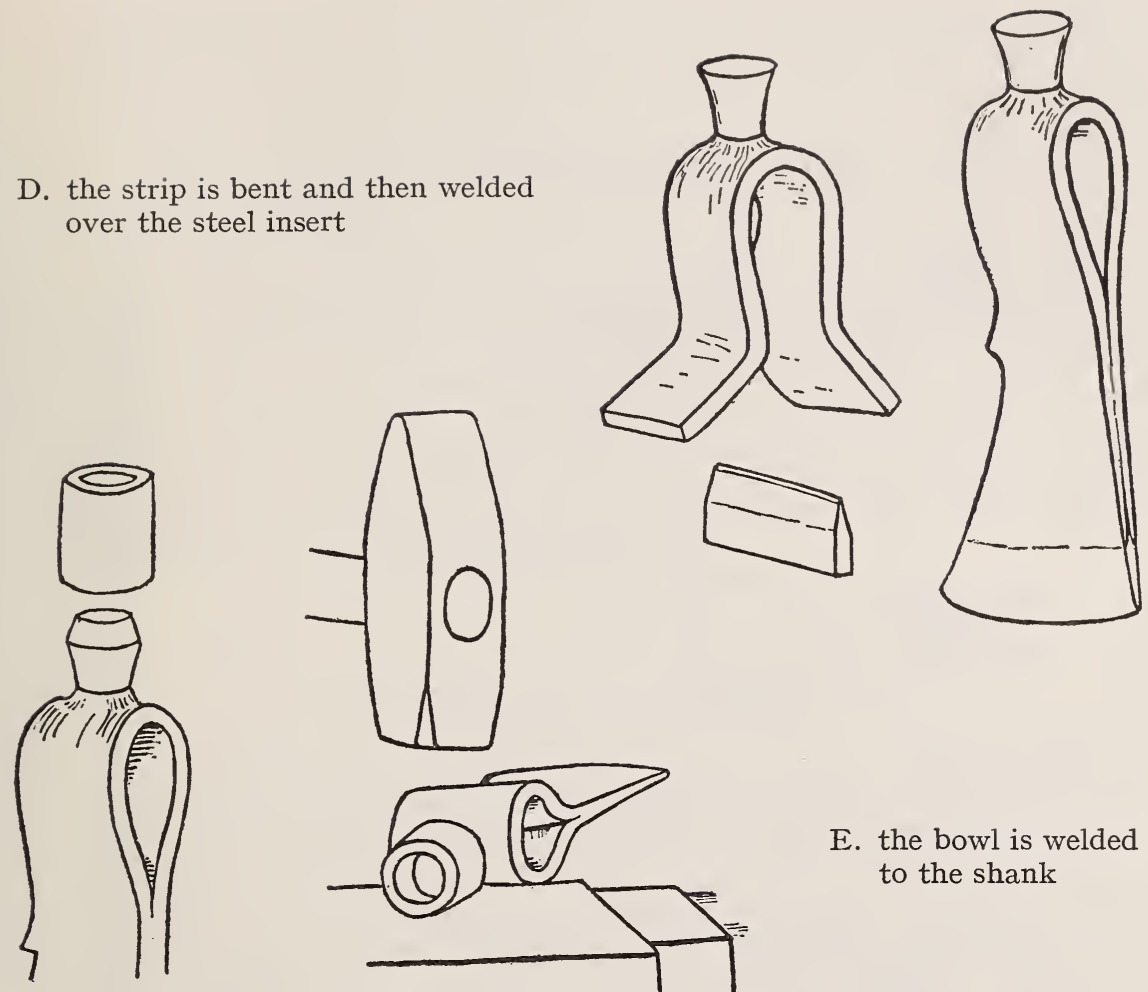

E. the bowl is welded to the shank

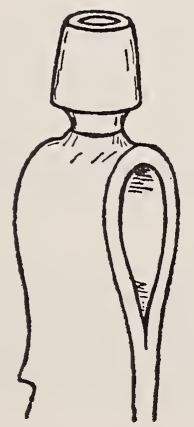

F. the eye is drifted to form and the tomahawk is filed to final shape

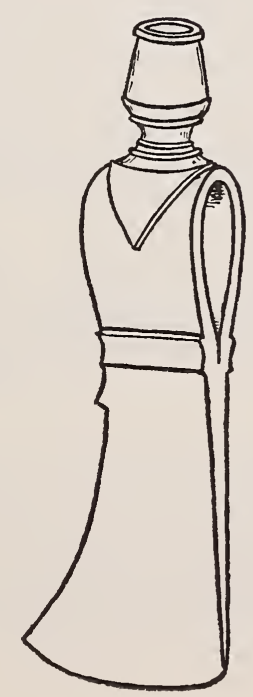

common pipe tomahawk. 


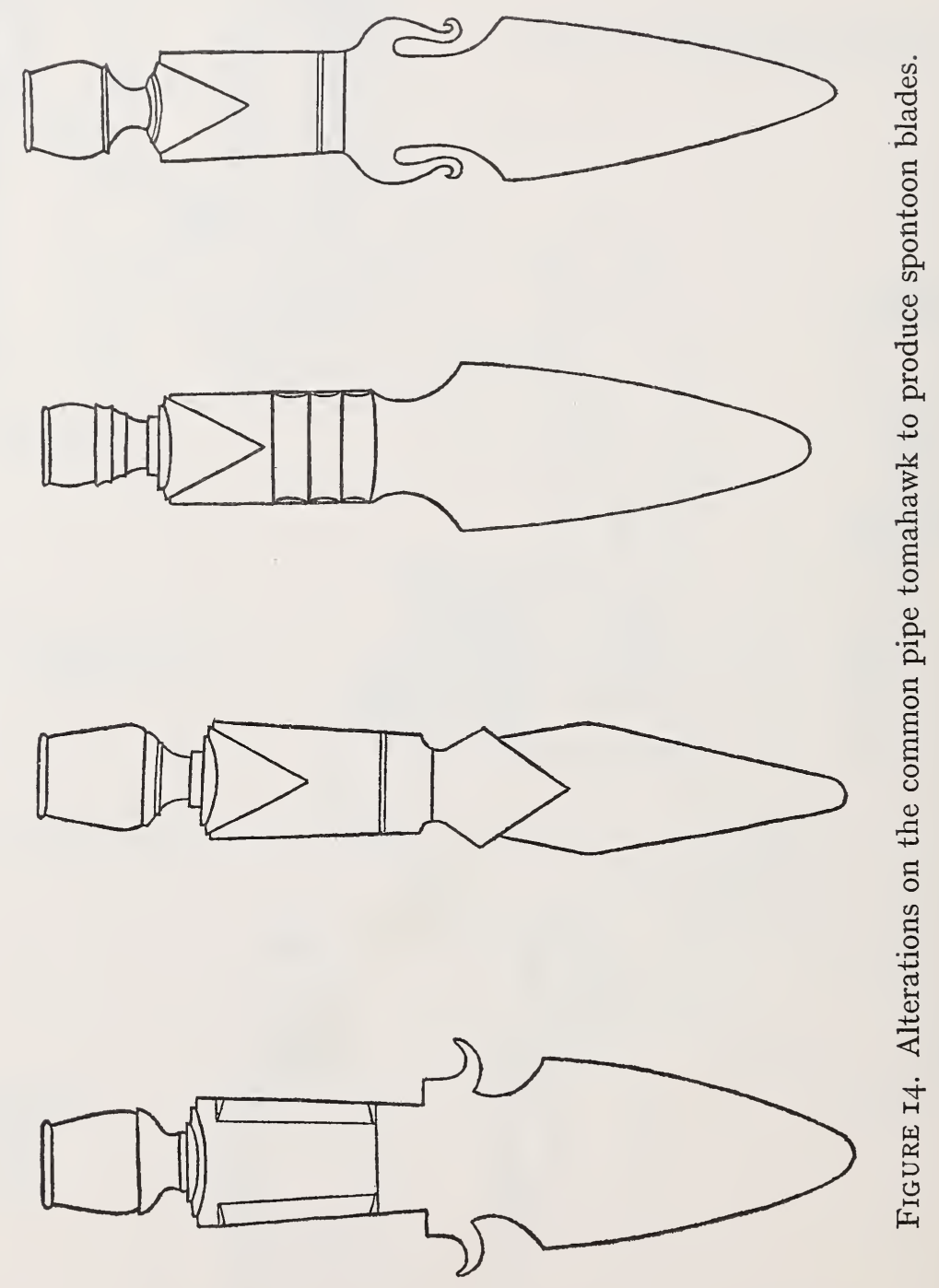


bowl and eye was trued up, and a small hole was drilled to connect the bowl with the eye. The forging was then ready for filing, tempering, and polishing.

Characteristics of tomahawks manufactured in this manner are: the generally true form of the eye and the absence of any seam at the apex of the oval.

In one interesting variant of this type, which I have seen, the outside of the eye opposite the blade had a depression, approximately the size of the bowl, punched into it. Then a section of tubular material (perhaps a musket barrel) was butt-welded into this depression and the tube was necked down to produce a shank and bowl. By looking at it from both the eye end and the bowl end, and by exploring it with a wire, the pocket was found at the point where the shank was joined to the eye.

\section{Gun-Barrel Technique}

In the early days, even in well-settled areas, iron was expensive. On the frontier the costs of transportation increased the price even more. Guns received rough usage and scrap gun barrels became an important source of iron. The tomahawk maker was quick to take advantage of the cylindrical shape (see Figure I6). A drill was not necessary for there was already a hole for the bowl, and no difficult welding was required. After the tube was necked down for the shank, it was flattened all the length from the shank to its far end. A slit was then cut and opened with a drift to form the eye. Sometimes a steel bit was welded to the cutting edge.

The bowl made in this manner was long, like the catlinite pipe bowls of the Plains Indians. The eye was merely spread at the middle and drifted to a diamond cross-section with rounded corners. The blade had nearly straight edges front and back and, since this shape did not lend itself to use in combat, it was usually not sharpened.

Such tomahawks are readily identified by the funnel-like opening which, with the handle removed, may be seen under the eye. Sometimes traces of the original rifling of the gun barrel can be seen on either side of the eye or bowl.*

* The gun-barrel technique was first described to me by Colonel Stobie who was agent to the Utes shortly after the Civil War. He went into detail as he had seen tomahawks made by the agency blacksmith at that time. I was rather surprised to get an identical description from Harry Burgess, who had spent his boyhood on the Pawnee reservation in Nebraska. His father was a Quaker appointed by President Grant to the agency. 


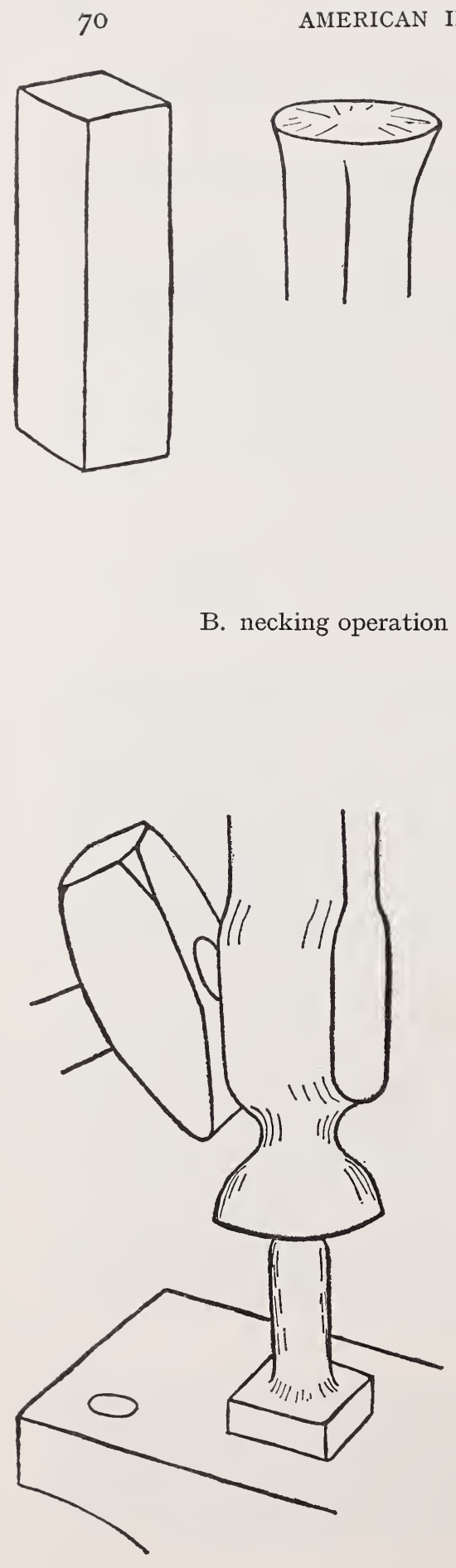

A. the bar of iron at start and after upsetting
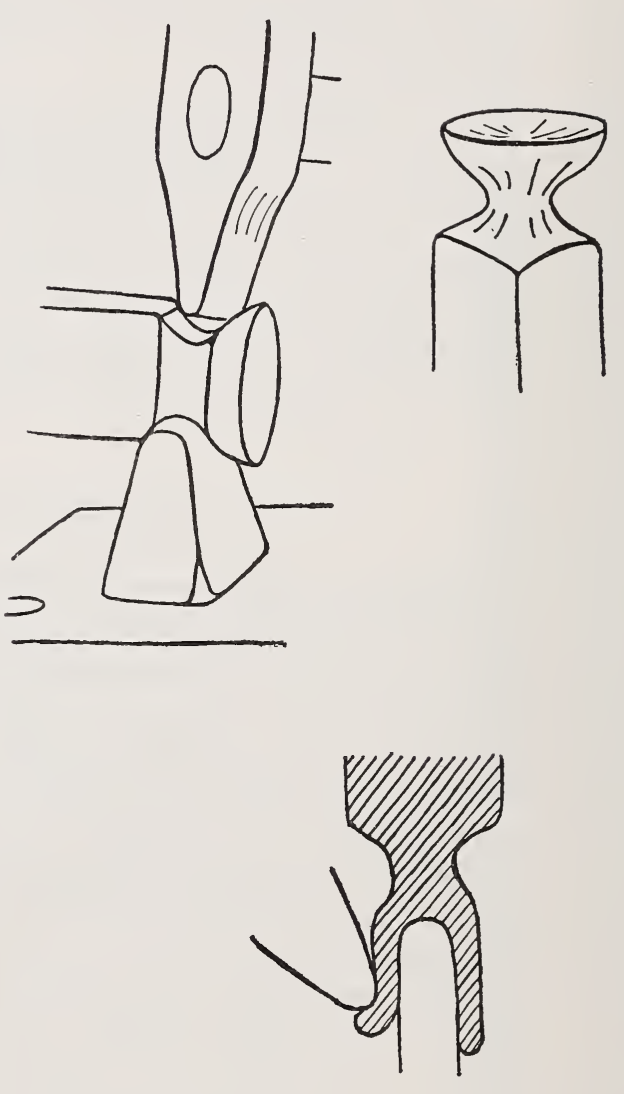

C. the bowl is drawn to a cylindrical shape

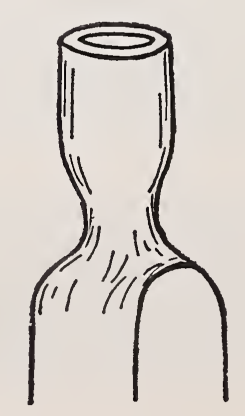

FIGURE I5. The pierced eye technique 

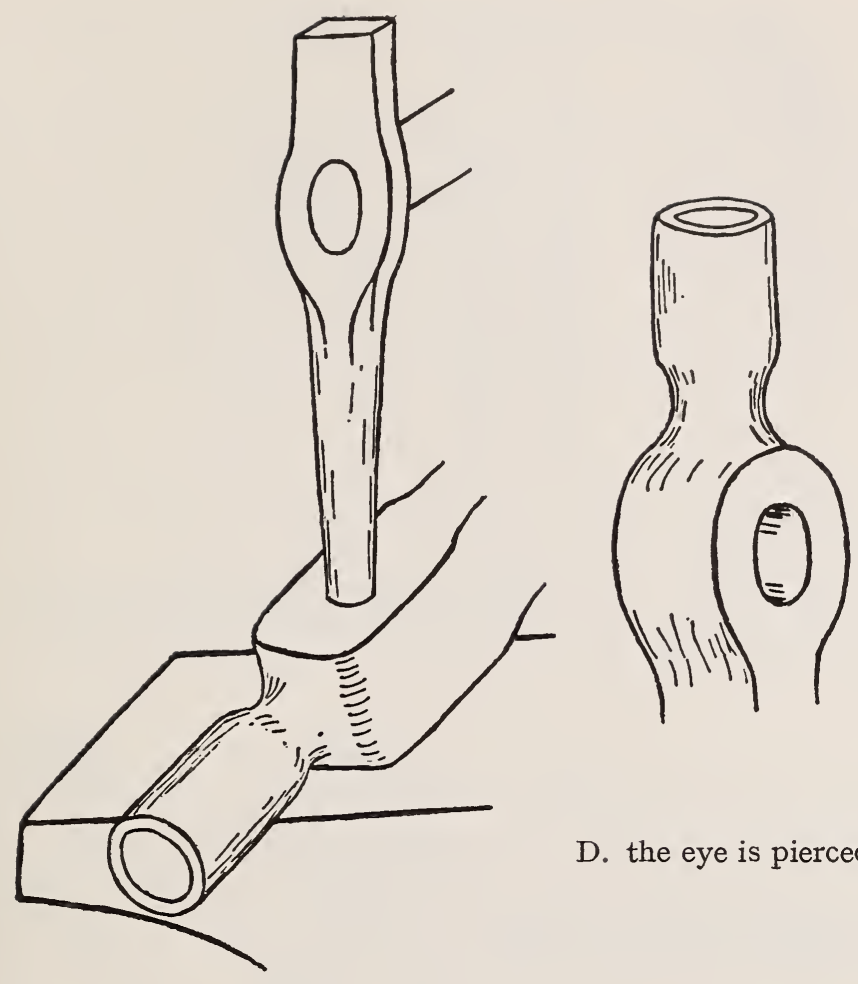

D. the eye is pierced

E. the eye is drifted to shape
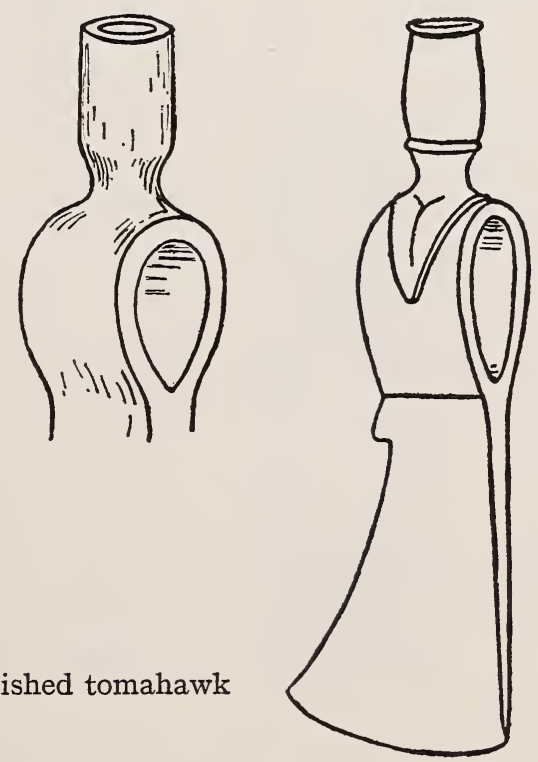

of making a tomahawk. 

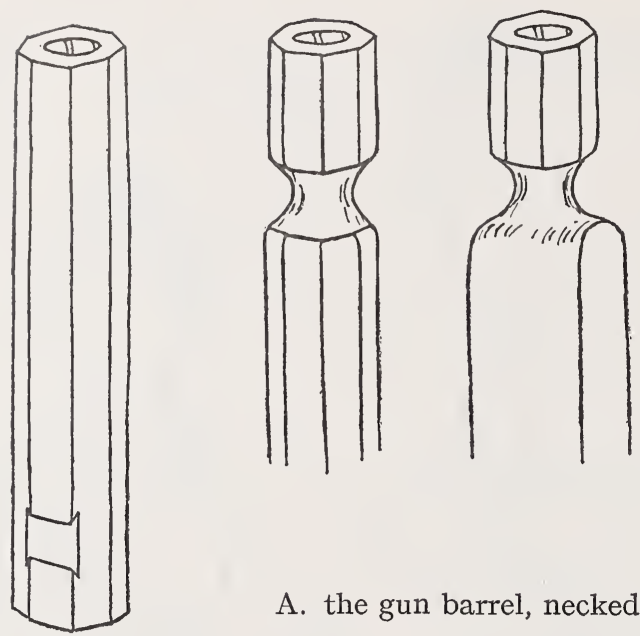

A. the gun barrel, necked and flattened

B. the eye slit and drifted to form, and the blade drawn to full width
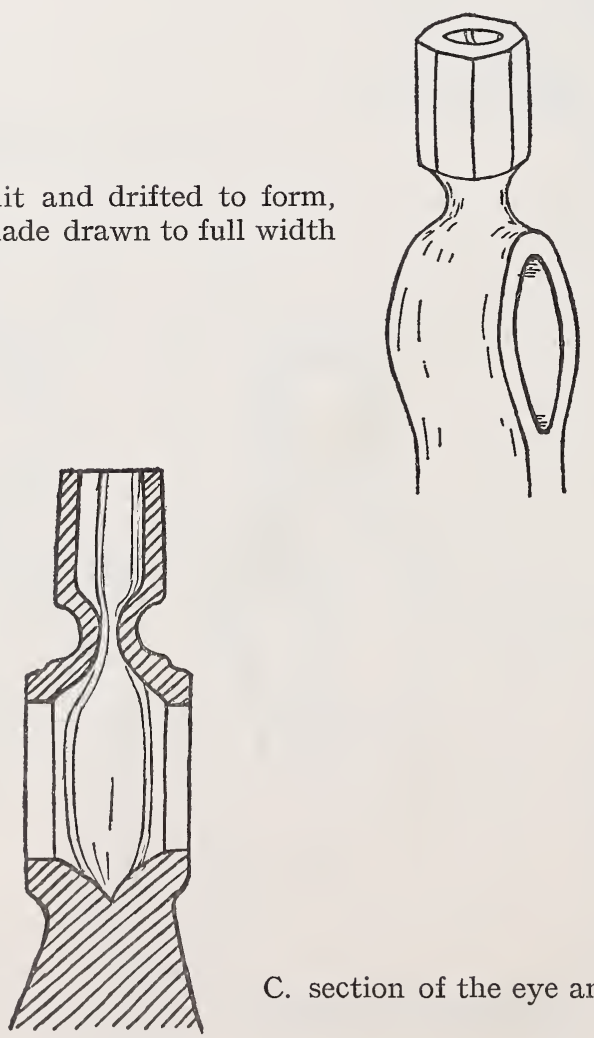

C. section of the eye and bowl

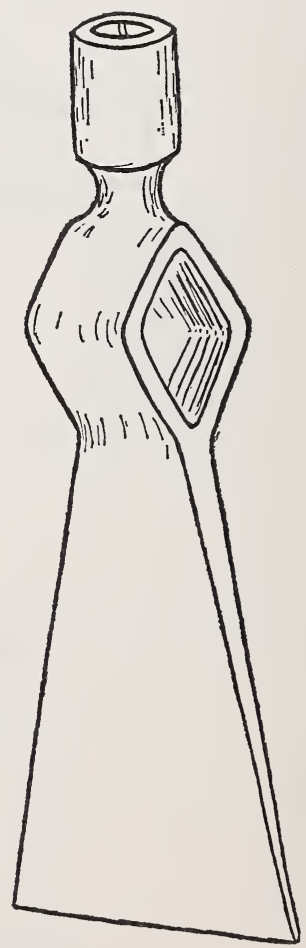

FigURE I6. Manufacture of a gun-barrel tomahawk. 


\section{Wrap-Around Eye and Blade with Drilled Bowl}

This method of manufacture combines the welded blade technique, such as was used to make the early axe, and a drilling operation, which required a machine. (A bit brace had been adequate for the small holes made in earlier examples.) A large bar stock of iron was also needed, and it is possible that sections cut from the axles of stage coaches were used for this. Some specimens show that a seamy wrought iron was used; in others, the metal is clear and appears to be what at that time was called "mild" steel.

Why did the smith revert to the older technique? One explanation is that it allowed a greater length of contact between the eye and handle, a feature difficult to achieve by using the pierced technique. Generally, although it would have been easy to incorporate, the added steel bit is absent and the edge is quite blunt. Spontoon blades were made in this way, as were the more common hatchets.

In manufacture (see Figure I7), the heavy section of bar was heated and the fuller used to reduce the thickness in the center on each side of what was to become the bowl. Then, the two ends were bent down so that the thinned portion formed the eye. The two ends were welded together and drawn out roughly to form the blade. Where the center section stood above the eye, the fuller and a chisel were used to neck the iron down to form the shank. The bowl was then forged to a round section to increase its height. The blade and eye were trued up with the flatter, chisel, and drift.

The bowl was very high and the shank long, so the depth of drilling exceeded any required on pipe tomahawks previously manufactured. It seems obvious that the maker must have had at least a hand-operated drilling machine, such as were available in blacksmith shops in the settled parts of the country, for he made no concession in technique to spare labor in drilling. A small bit was used to bore through the entire length of the bowl and shank to the eye. A larger bit was used to drill out the bowl. (The smiths generally made their own drills and tempered the working ends, and lard oil was used as a lubricant.) The forging was then ready for finishing and ornamentation.

Characteristics of tomahawks of such manufacture are: a high bowl, a pointed oval eye, usually a seam in the area where the weld starts, and a definite angle at the bottom of the bowl where the drill stopped. 

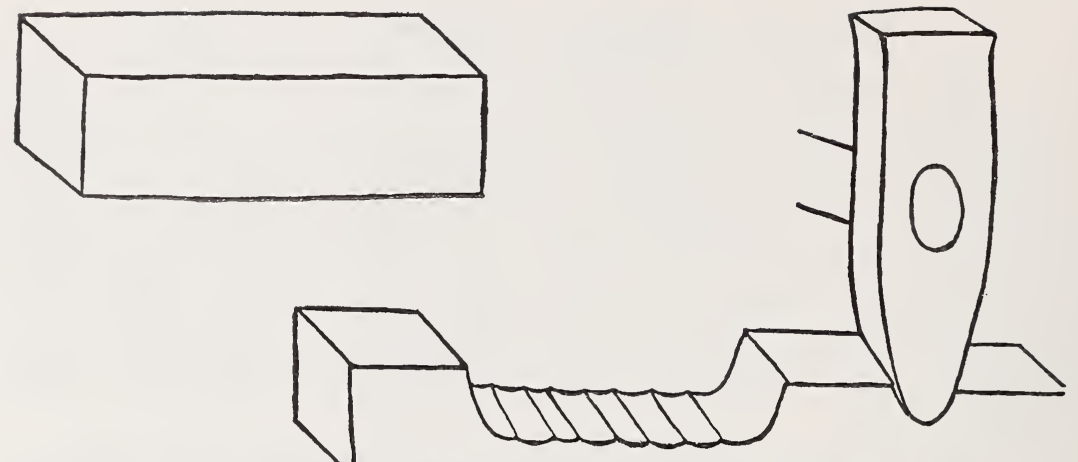

A. bar stock and first operation

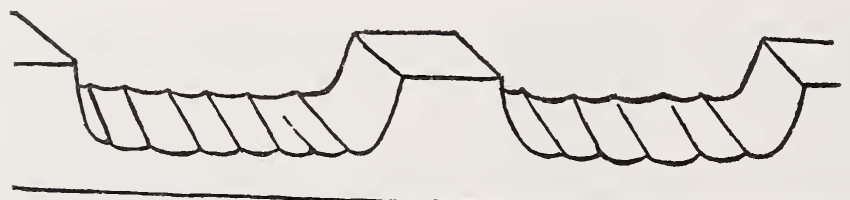

B. bar drawn out, bent, and welded
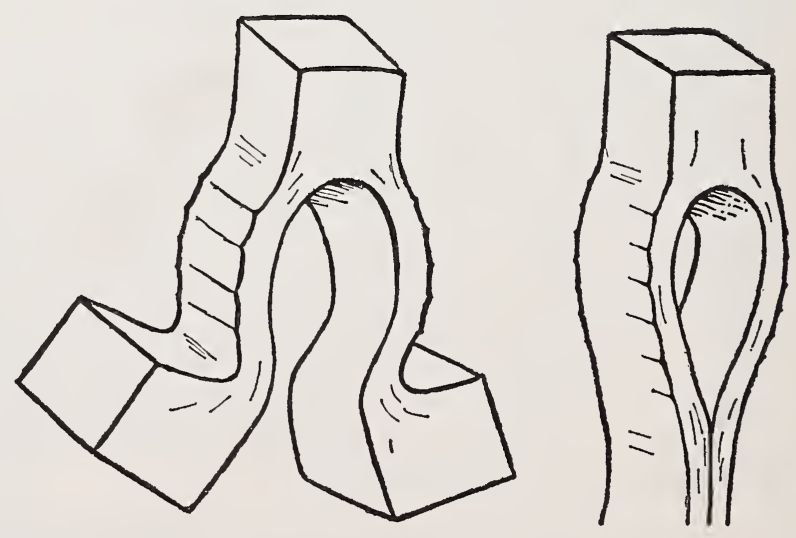

FIGURE I7. Manufacture of a pipe tomahawk 


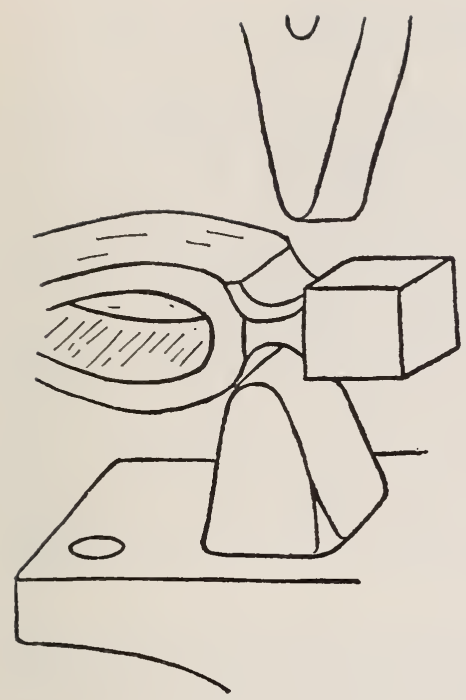

C. bowl, necked and drawn out
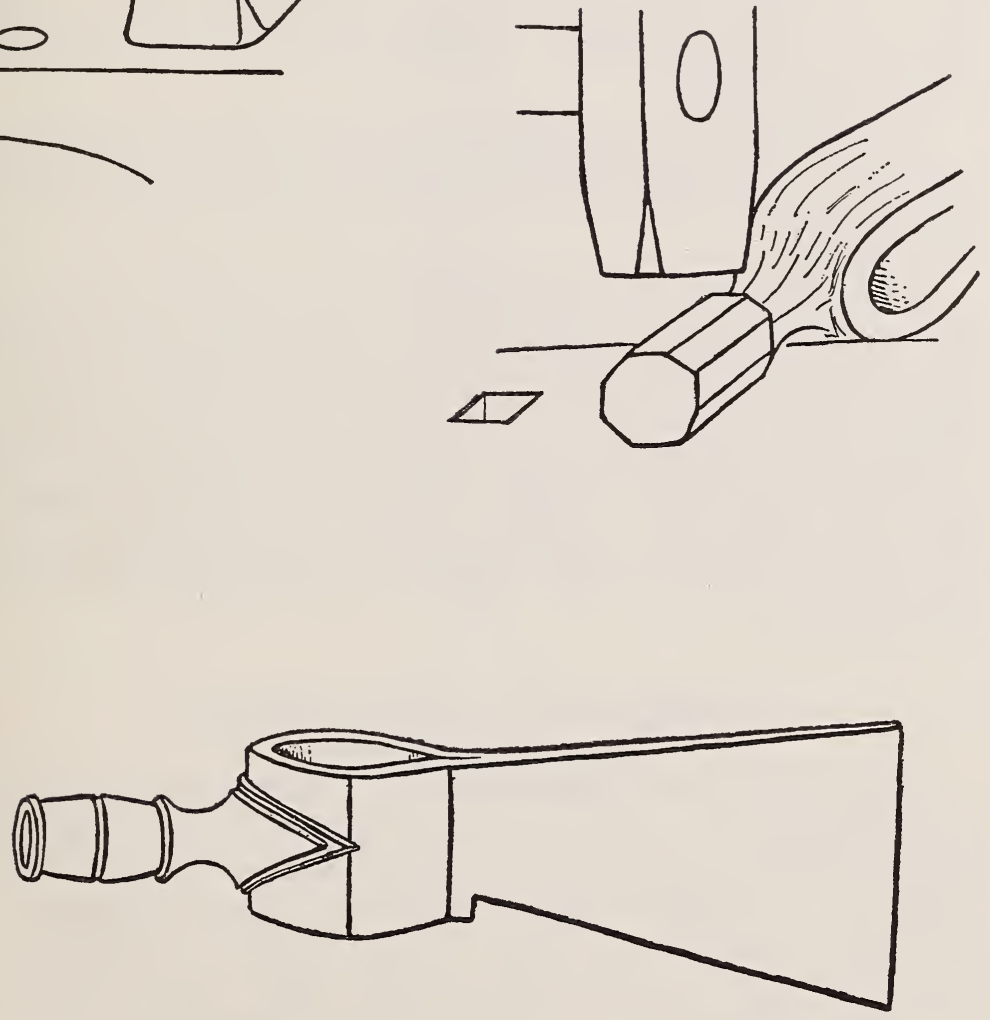

D. the finished forging, drilled and filed

using the "wrap-around eye and blade" technique 


\section{REPAIR AND REWORKING}

In wooded country it was quite natural that the small axe and even the pipe tomahawk were used for chopping. As they wore, blades were sometimes taken to the blacksmith for "dressing." To do this, the blade was thinned at the cutting edge to be reforged and retempered. Little grinding was required to sharpen the edge and the resulting acute angle cut wood more efficiently.

The steel bit did not extend very far up into the body of the blade. Often, through wear and resharpening, it would be completely worn away and only the body of soft iron remained. If a new bit was necessary, a piece of steel was simply welded to one side of the blade. This was called a "lap" weld. Later, when the metal was more plentiful, a V-shaped piece of steel was welded over the worn edge.

The shortness of some blades may be accounted for by a method of repair that duplicated the manufacturing process. In this, the edge was upset, a slit was cut in the iron, and a steel bit was welded into the slit.

In the Midwest, the spontoon blade was popular, and it would appear from existing specimens that some blades of the common type were reworked to this newer shape (see Figure I4). This, of course, would indicate that the owner had given up all thought of using his tomahawk as a chopping tool, even though a trace of the steel from the original cutting edge might still remain in the point. Ordinarily, a spontoon blade was used only as a pipe or symbolic weapon rather than for practical purposes, and had no steel in it.

\section{THE INDIAN BLACKSMITH}

Indians took up blacksmithing at an early date, as attested by David Zeisberger, the Moravian missionary who worked among many different tribes in the years between I740 and I808. In addition to forging, Indians learned casting techniques and decorated tomahawks, knife handles, pipes, and flutes with elaborate inlays of lead and pewter. They cast a number of types of tomahawk heads of lead alloys, preferring Babbit metal for this purpose. They came in contact with this alloy while working in lumber mills and appreciated its hardness and lustre as compared to bullet lead. Before this was available, they saved the foil from tea boxes and, around country printing shops, they collected worn-out printing type, which was also prized for its hardness. 
Where the Indians lived in pioneer settlements, they were able to take advantage of the heavy tools of their white employers to make forged tomahawks and knives. Since there was a steady demand from their tribesmen, some of their work remains in collections today. For example, one tomahawk I have seen, which had a pierced eye and a drilled bowl with a spontoon blade (see Figure I8), was made by a Carlisle graduate. In the more remote villages, though, Indian ironwork was largely confined to the making of knives and spearheads from rasps and files.

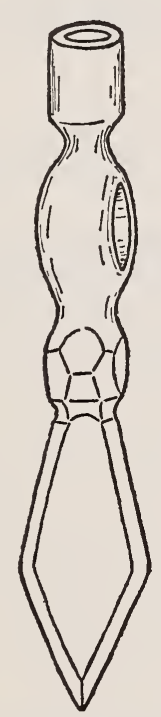

FIGURE I8.

An Indian's modification of a ball-peen hammer to make a tomahawk. 


\section{BIBLIOGRAPHY OF WORKS CITED}

The following list should not be construed as a complete bibliography of the works consulted in the preparation of the present study. It contains only those works with sufficient information to cause them to be cited in the text. In addition to the printed materials listed, the following manuscript sources were also used: Original Journals of the Lewis and Clark Expedition, I804-I806 in the American Philosophical Society, Philadelphia, and the records of the Army, Navy, and Office of Indian Trade in the National Archives, Washington.

\section{ANBURey, THOMAS}

I79I Travels Through the Interior Parts of America, 2 vols., London.

Beauchamp, William M.

I902 "Metallic Implements of the New York Indians," New York State Museum Bulletin 55, 92 pp.

I946 The Beaver, (March issue of magazine published by Hudson's Bay Company), p. 30.

Benjamin, Park, (ed.).

I880 Appleton's Cyclopaedia of Applied Mechanics, 2 vols. New York: D. Appleton \& Co.

BRECKENRIDGE, R. W.

I955 "Norse Halberds," American Anthropologist, LVII, \# I, part I, pp. I29-I3I.

CARTIER, JACQUeS

I924 The Voyages of Jacques Cartier, (H. B. Biggar, editor), Ottawa.

Catesby, Mark

I73I- The Natural History of Carolina, Florida, and the Bahama IsI743 lands, 2 vols. London.

Catlin, George

I926 North American Indians, 2 vols. Edinburgh: J. Grant.

Champlain, Samuel DE

I907 The Voyages of Samuel de Champlain, I604-I6I8, (W. L. Grant, editor). New York: Charles Scribner's Sons, 377 pp.

\section{ChURCh, Thomas}

I7I6 Entertaining Passages Relating to Philip's War, Boston, $360 \mathrm{pp}$.

Clark, S. A.

I905 Pioneer Days of Oregon. Portland, Oregon.

Craigie, Sir William, and James R. Hulbert, (eds.)

I944 A Dictionary of American English, 4 vols. Chicago: University of Chicago Press.

CREUXIUX, Francisco

I664 Historia Canadensis sen Nova Francia. Paris. 
Driver, Harold E., and William C. Massey

I957 "Comparative Studies of North American Indians," Transactions of the American Philosophical Society, XLVII, part 2, pp. $165-456$.

ELMER, EBENEZER

I847, "Journal Kept During an Expedition to Canada in I776,"

I848 New Jersey Historical Society, Proceedings, II, pp. 97-I46, I 50-I94; and III, pp. 21-56, 90-IO2.

Ewers, JoHn C.

I955 "The Horse in Blackfoot Indian Culture," Bureau of American Ethnology, Bulletin I59, Washington, D. C., 374 pp.

Fowler, William S.

I95I "Tomahawks of Central New England," Bulletin of the Massachusetts Archeological Society, XII, No. 3, pp. 29-37.

Fowler, William S.

I952 "Trade Tomahawks," Bulletin of the Massachusetts Archeological Society, XIII, \#3, pp. 23-27.

GaRcilaso DE LA VEGA

I95I The Flovida of the Inca, (edited by John G. and Jeanette J. Varner). Austin: University of Texas Press, $655 \mathrm{pp}$.

GERARD, WiLliam

I908 "The Term Tomahawk," American Anthropologist, n. s., X, \#2, pp. 277-280.

GREELEy, HORACE, and others

I872 The Great Industries of the United States. Chicago: J. B. Burr, Hyde \& Co., I304 pp.

Hoadley, Charles J., (ed.)

I850- Public Records of the Colony of Connecticut, I5 vols. Hartford, I890 Conn.

Hodge, Frederick W., (ed.)

I909 "Handbook of the American Indians North of Mexico," Bureau of American Ethnology, Bulletin 30, 2 vols. Washington, D. C.

Holmes, William H.

I908 "The Tomahawk," American Anthropologist, n. s., X, \#2, pp. $264-276$.

JEFFERY, THOMAS

I757- Collection of Dresses of the Different Nations. London.

I772

JEFFREYS, C. W.

I945 The Picture Gallery of Canadian History. Toronto.

KEPPLER, JOSEPH

I929 "The Peace Tomahawk Algonkian Wampum," Indian Notes, VI, \#2, pp. I30-I38.

KURZ, RUdOLPH FRIEDERICH

I937 "Journal of Rudolph Friederich Kurz," Bureau of American Ethnology, Bulletin II5. Washington, $382 \mathrm{pp}$. 
LAFARge, Oliver

1956 A Pictorial History of the American Indian. New York: Crown Publishers, $272 \mathrm{pp}$.

Lawson, Cecil C. P.

I940- A History of the Uniforms of the British Army, 2 vols. London:

I94I Peter Davies, Ltd.

LeffFerts, Charles M.

I926 Uniforms of the American, British, French and German Armies in the War of the Revolution. New York: The New-York Historical Society, $289 \mathrm{pp}$.

LORANT, Stefan

I946 The New World. New York: Duel, Sloan \& Pearce, 392 pp.

Lossing, Benson J.

I869 Pictorial Field-book of the War of I8I2. New York: Harper \& Brothers, I084 pp.

MASON, Otis T.

I897 "The Tomahawk of the North American Indian," The American Naturalist, XXXI, \#369, pp. 824-826.

McGuire, Joseph D.

I899 "Pipes and Smoking Customs of the American Aborigines," Annual Report of the U.S. National Museum for I896, Washington, D. C., pp. 35I-645.

McKenney, Thomas L., and James Hall

1933. The Indian Tribes of North America, 3 vols. Edinburgh: J. I934 Grant.

MERCER, HENRY C.

I950 Ancient Carpenter's Tools. Doylestown: Bucks County Historical Society, 2 nd edition, $339 \mathrm{pp}$.

Morgan, Lewis H.

I904 League of the Ho-dé-no-sau-nee or Iroquois. (edited by Herbert M. Lloyd). 2 vols. in one. New York: Dodd, Mead \& Co.

O'Callaghan, Edmund B., and others, (eds.)

I853- Documents Relative to the Colonial History of New York, I 5 vols., I887 Albany.

OLson, JoHn, (ed.)

1906 "The Saga of Eric the Red, also Called the Saga of Thorfinn Karlsefni," in The Northmen, Columbus and Cabot, 985-I503. New York: Charles Scribner's Sons, pp. 3-43.

1906 "The Vinland History of the Flat Island Book," in The Northmen, Columbus and Cabot, 985-I503. New York: Charles Scribner's Sons, pp. 45-65.

I87I One Hundred Years of Progress. Hartford: L. Stebbins.

I866 Ordnance Instructions for the United States Navy. $4^{\text {th }}$ edition, Washington, Government Printing Office, 297 pp.

Peterson, Harold L.

I956 Arms and Armor in Colonial America, I526-I783. Harrisburg: The Stackpole Company, $350 \mathrm{pp}$. 
Pohrt, Richard A.

I957 "Two Tomahawks and an Iron Pipe," Ohio Archeologist, -VII, \#2, pp. 70, 7I.

Russell, Carl P. Material Things of the American Traders and Trappers, typescript of a book in preparation.

Russell, OsBorne

I955 Journal of a Trapper. Oregon Historical Society, Portland, Oregon, I79 pp.

Schellbach, Louis

I928 "An Historic Iroquois Warclub," Indian Notes, V, \#2, pp. I57-I66.

Schoolcraft, Henry R.

I85I- Historical and Statistical Information Respecting the History,

I857 Condition and Prospects of the Indian Tribes of the United States. 6 vols. Philadelphia: Lippincott, Grambo \& Co.

Sмiтн, JонN

1907 "A Map of Virginia," in Narratives of Early Virginia, $1606-1625$. Lyon Gardiner Tyler, (editor). New York: Charles Scribner's Sons, pp. 73-203.

Swanton, John R.

I946 "The Indians of the Southeastern United States," Bureau of American Ethnology, Bulletin 137. Washington, D. C., 943 pp.

ThIROUx, M.

I849 Instructions Théoretique et Practique d'Artillerie. 3 rd edition, Librairie Militaire de J. Dumaine, Paris, 563 pp.

Timberlake, LT. HenRY

I927 Lieut. Henry Timberlake's Memoirs, I756-1765, (Samuel Cole Williams, editor). Johnson City, Tennessee.

West, George A.

I934 "Tobacco, Pipes and Smoking Customs of the American Indians," Bulletin of the Public Museum of the City of Milwaukee, 2 vols. Milwaukee.

WHEELER, RoBert F.

I957 "The American Belt Axe, 1650-1870," The American Arms Collector, I, \# 4, pp. I27-130.

Wildschut, William, and John C. Ewers

I959 "Crow Indian Beadwork," Contributions from the Museum of the American Indian, XVI. New York, 55 pp.

Withers, Alexander S.

I 895 Chronicles of Border Warfare. Cincinnati: Robert Clarke Company, $447 \mathrm{pp}$. Reprint of the I83I edition.

WOOD, WILLIAM

I898 New England's Prospects, reprint, n. p.

WOODWARD, ARTHUR

I946 "The Metal Tomahawk, Its Evolution and Distribution in North America," Bulletin of the Fort Ticonderoga Museum, VII, \#3, pp. 2-42. 

CAPTIONS TO PHOTOGRAPHS 



\section{ABORIGINAL FORMS}

1. An example of the $\mathrm{I} 7$ th century Virginia ball-headed clubs commonly referred to by the early colonists as tomahawks. This specimen found its way into the collections of John Tradescant (I608-I662), a notable traveler, naturalist, and Royal gardener who was greatly interested in the newly settled colony at Jamestown and collected both botanical and ethnological specimens from Virginia. It displays the large size and sharp drop to the ball typical of the early clubs of this form. (British Official Photograph: Crown copyright reserved).

$\mathrm{L}: 2 \mathrm{I}^{\prime \prime}$

Ashmolean Museum, Oxford

I685 Cat.B. I33-5

2. Ball-headed club tomahawk, probably early igth century. The drop of the haft is not so sharp as that of the previous specimen, and the ball is somewhat smaller in proportion. Nevertheless it is a good functional weapon, fashioned from a single piece of wood. Especially interesting are the incised figures of two fighting Indians on the obverse side, one armed with a bow and arrow, the other wielding a ball-headed club which seems to have an iron blade. Definitely an eastern Indian type, it has been attributed to the Iroquois.

L: $24 \frac{1}{2}^{\prime \prime}$

MAI/HF : I $8 / 4922$

3. A ball-headed club tomahawk of the mid-r8th century with an iron blade. This important specimen was presented to Sir William Johnson after I746 and before I755. It is inscribed on the underside of the handle WATKONOCHROCHQUANYO [I present it to thee freely out of respect] WARRAGHIYAGEY [the name given to Johnson when he became a Mohawk war chief in I746]. On the top of the handle is "og8entaguete le camarade jeanson" [the name of an Onondaga warrior who probably presented the weapon to Johnson, and an identifying phrase indicating he was a comrade of Sir William]. On the obverse side are thirteen joined human figures, each holding a gun; and on the reverse is a series of exploit marks designed to record the number of times the owner engaged in battle and whether he had been wounded. The forward end of the haft is carved as an animal's head, and there are some conventional incised decorations. L: $23^{\prime \prime}$

William O. Sweet collection

4. Ball-headed club tomahawk, late 18 th century. The straight haft resembles the Johnson tomahawk described above as to the angle and amount of drop to the ball. The ball is smaller, and the specimen is relatively light but is still a functional weapon. The haft in the area of the drop is shaped in profile to resemble an animal's head, holding the ball in its mouth. It is flat sided except for a short section near the butt, which has been rounded to afford a better grip. The butt itself is flat sided and slightly larger than the grip as a further aid in retaining a good hold of the weapon when striking. Just in front of the grip the haft is pierced for a thong. Attributed to the Chippewa.

L: $2 \mathrm{I}^{\prime \prime}$

$\mathrm{MAI} / \mathrm{HF}: 2 / 46 \mathrm{I} 3$ 
5. Ball-headed club tomahawk with iron blade, Igth century. This is a highly sophisticated example with refinements indicative of Plains Indian design. The small decadent ball, the protruberance on the lower edge of the hat, and the type of decoration all point to the western Indian and the early I9th century. The decoration consists of brass-headed tacks in pattern groupings on both haft and ball, incised follow lines, and raised carving. Most significant is the stylized carving of an otter on the forward edge of the drop, which undoubtedly symbolized the original owner's supernatural helper. The butt of the haft is pierced for a thong, and the grip area is wrapped with a narrow band of fur. Collected from the Oto in Oklahoma. $\mathrm{L}: 23 \frac{1}{2}^{\prime \prime}$

$\mathrm{MAI} / \mathrm{HF}: \mathrm{I} / 3555$

6. Ball-headed club tomahawk, probably late Igth century. In this specimen the functional qualities of the weapon have almost entirely disappeared. The balance is poor, and the ball is decadent, being both small and poorly shaped. The decoration consists of brass-headed tacks in some profusion. A feather has been attached to one of the tacks just above the ball. Collected in Iowa, it is also typically western.

L: $27^{\prime \prime}$

MAI/HF : I/3973

7. Ball-headed club tomahawk, very late igth century. A grotesque descendant of the early weapon, this one-piece specimen was made from a burl and branch rather than cut down from a large block of wood in the traditional manner. The haft, in fact, follows the original contour of the branch. There is a slight enlargement at the butt and some notched decoration in the grip area, but otherwise the limb has simply been smoothed. The ball, on the other hand, has been carved in typical Northwest Coast designs. Collected from the Haida.

L: $18^{\prime \prime}$

$\mathrm{MAI} / \mathrm{HF}: 5 / 789$

8. Polished stone celt with its original wooden haft. It was this type of hatchet which the colonists found the Indians using and calling tamahak. Like its metal successors, it could be used either as a tool or weapon. This pre-contact specimen was found in Arkansas. See also No. 9.

H: $6 \frac{3^{\prime \prime}}{4} \mathrm{~W}: 2 \frac{3}{8}^{\prime \prime} \mathrm{L}: \mathrm{I} 9 \frac{1}{4}^{\prime \prime}$

$\mathrm{MAI} / \mathrm{HF}: \mathrm{IO} / 4996$

9. Celt tomahawk with flaked stone head. Some had chipped stone heads, and a few writers have felt that these were more apt to have been weapons than tools. This pre-contact specimen with its original wooden haft is from Benton County, Arkansas. See also No. 8.

$\mathrm{H}: 4 \frac{1}{4}^{\prime \prime} \mathrm{W}: 2 \frac{1}{2}^{\prime \prime} \mathrm{L}: \mathrm{I} 4 \frac{1}{4}^{\prime \prime}$

MAI/HF : II/7235

10. Copper celts. There were celts of native copper as well as of stone long before the era of the trade hatchet. This pair is from a large cache of such hatchets found together in the Spiro Mound, Le Flore County, Oklahoma. The wooden hafts are carved to resemble birds' heads at the point where the blade passes through, with the eye indicated by a circular shell inlay. Dimensions given are for the largest specimen.

$\mathrm{H}:$ Iо $\frac{5}{8}^{\prime \prime} \mathrm{W}: \mathrm{I}_{\frac{3}{4}}^{\prime \prime} \mathrm{L}: \mathrm{I} 8^{\prime \prime}$

MAI/HF : I $8 / 9077$

11. Polished stone celt with original haft of wood. This specimen closely resembles No. 8, but has a slightly longer haft and a more sharply defined 
anterior section through which the stone blade passes. Found in a cleft in a rock bluff on the Buffalo River near Yellville, Arkansas.

L: $19 \frac{1}{2}^{\prime \prime}$

MAI/HF : IO/4996

12. Full grooved stone axe with reconstructed haft to show manner of hafting. The hickory handle is wrapped around the head and lashed with a rawhide thong. Axes such as this were almost always tools although they could have been used as weapons in an emergency. Collected in Saskatchewan. $\mathrm{L}: \mathrm{I} 6^{\prime \prime}$

$\mathrm{MAI} / \mathrm{HF}: 22 / 7240$

13. Full grooved axe with original haft. This specimen, found in a cave in Mesa Verde, Colorado, is grooved nearer the center of the head. The mass of stone above the handle thus helps to balance the weight of the blade and so affords a steadier stroke. The haft is composed of a light withe, which is wrapped completely around the head and back along its own length.

$\mathrm{H}: 6^{\prime \prime} \mathrm{L}: \mathrm{I} 7^{\prime \prime}$

$\mathrm{MAI} / \mathrm{HF}: 5 / 8533$

14. Monolithic ceremonial axe. Like the superb specimen described below, this axe is fashioned from a single piece of stone. In all major respects it is identical except for the quality of workmanship. Minor differences include the shape of the forward end, the amount of the "blade" projecting above the "haft," and the butt piercing, which is horizontal instead of vertical. Found along the Cumberland River opposite Nashville, it also represents the Mississippian culture horizon.

$\mathrm{H}: 6^{\prime \prime} \mathrm{L}: 13 \frac{1^{\prime \prime}}{4}$

MAI/HF : 7775

15. Indicative of the importance of the early stone axe in playing a ceremonial as well as a utilitarian role-just as did its metal successor-are the superb axes carved from a single block of stone, found in various areas of the southeastern United States. Useless as a tool or weapon, they are marvelous examples of craftsmanship in stone. Most of these represent the Mississippian culture horizon, and date from between 900-I600 A.D. This specimen, excavated at Moundville, Alabama, by Clarence B. Moore in I909, has a small hole drilled in the base, presumably for a thong.

$\mathrm{H}: 5 \frac{3^{\prime \prime}}{4} \mathrm{~W}: 2 \frac{1}{2}^{\prime \prime} \mathrm{L}: \mathrm{II} \frac{3^{\prime \prime}}{}$

$\mathrm{MAI} / \mathrm{HF}: \mathrm{I} 7 / 89 \mathrm{I}$

16. Monolithic ceremonial axe of the type commonly termed a "slave killer." Outside the Mississippian culture, monolithic axes tended to follow designs far removed from the standard axes of the period. This example is zoömorphic in design with only slight resemblance to the functional tool. It was carved from black slate, probably about I500 A.D. Excavated on Gunther Island, Arcata Bay, California, it bears evidences of cremation.

$\mathrm{H}: 6 \frac{1}{4}^{\prime \prime} \mathrm{L}: \mathrm{I} 5^{\prime \prime}$

$\mathrm{MAI} / \mathrm{HF}: 23 / \mathrm{I} 874$

17. Monolithic ceremonial "slave-killer." This specimen of black slate more closely resembles the standard celt but is capped by a carved eagle's head at the forward end in typical Northwest Coast style. This head is, in turn, decorated with tufts of hair set in holes drilled in the stone. The sharply curved haft is chamfered in the area of the grip and bears an incised design representing a "tinneh," the coppers used as symbols of wealth in the Northwest. Collected from the Kwakiutl, Vancouver Island, British Columbia, it dates to about 1875 .

$\mathrm{H}: 8 \frac{1}{2}^{\prime \prime} \mathrm{L}: 13 \frac{1}{2}^{\prime \prime}$

$\mathrm{MAI} / \mathrm{HF}: 5 / 5062$ 
18. Monolithic ceremonial "slave-killer." Like the preceding specimen, this axe is fashioned from black slate and was made about I850-1875. The workmanship is much finer and the eagle head more stylized. It was never tufted. Collected at the mouth of the Fraser River, British Columbia, from the Kwakiutl.

$\mathrm{H}: 7^{\prime \prime} \mathrm{L}: \mathrm{I} 3^{\prime \prime}$

MAI/HF : I $4 / 4346$

19. Ceremonial stone "slave-killer," early Igth century. Closely related to the celt, this elongated blade is hafted in the same manner as numbers 8 and II. Except for the forward terminal and the enlarged butt, in fact, the haft is quite similar to these specimens. The haft is painted red and black. The forward terminal is carved and painted to resemble a human head and is even adorned with hair. Collected in Alaska from the Tlingit.

$\mathrm{H}: \mathrm{I}^{\prime \prime} \mathrm{L}: 23 \frac{1}{2}^{\prime \prime}$

MAI/HF : I $8 / 8554$

20. Elkhorn club of the "slave-killer" type, with stone blade. The antler from which the haft is fashioned has been smoothed and decorated with incised abstract zoömorphic designs. The fore end is carved as an animal head, and the leaf-shaped stone blade is cemented into a socket in one prong of the antler. Collected from the Tsimshian, Skeena River, British Columbia.

L: $I 5 \frac{1}{2}^{\prime \prime}$

$\mathrm{MAI} / \mathrm{HF}: \mathrm{I} 5 / \mathrm{I} 346$

21. Four gunstock clubs. This form of club has been recorded as early as the beginning of the $\mathrm{I} 7$ th century. It remained in use as a weapon among the western Indians until after I850 and continued to be made for ceremonial purposes for many years thereafter. The specimen at the left bears a flaked chert point, mounted in the early manner. Nevertheless it is a Igth century piece, attributed to the Chippewa. The incised decoration is accented with black, red, and green paint. (L: $\left.3 \mathrm{I}^{\prime \prime}\right)$. The second club, also of Igth century style, is noteworthy for its pierced decoration. Incised lines follow the edges of the club and the borders of the piercings while brass-headed tacks are also used along some of the borders. The iron point is crudely fashioned. It is attributed to the Sioux. (L: $\left.3 I^{1^{\prime \prime}}\right)$. The third specimen boasts a spear point, obtained from traders, and brass-headed tacks set in a circle. It was acquired from the Teton Sioux about the middle of the last century, at which time it must have been relatively new. (L: $\left.3 \mathrm{I}^{\frac{1}{2}}{ }^{\prime}\right)$. The righthand specimen is less a gunstock club than a variant of the celt with a blade made from a knife instead of polished stone. The fore end is cut on a slant and edged with three incised follow lines. A cluster of feathers is attached to the tip. The haft is flat sided in the area of the blade, then rounded to the butt, which is enlarged to prevent the hand from slipping off. It is late Igth century and is attributed to the Sioux. (L: $32^{\prime \prime}$.)

$$
\text { MAI/HF : 2I/2IO3, I8/49II, I6/5I72, I/964I }
$$

22. Gunstock club, mid-Igth century. A long slender variant of the gunstock club, it is one step further removed from the classical form than No. 23, which retains more of an angle at the point of percussion. The three blades of this specimen are made of horn. The decoration consists of seven unequally spaced rings of brass-headed tacks around the haft plus feathers attached to the fore end. Attributed to the Sioux..

L: $42 \frac{3}{4}^{\prime \prime}$

$\mathrm{MAI} / \mathrm{HF}: 7 / 4305$ 
23. Sitting Bull's gunstock club. Collected from the famous Hunkpapa Sioux leader by General Nelson A. Miles, this long slender variant of the gunstock club boasts three bowie knife blades of about I850, stamped on their ricassos MANHATTAN/ CUTLRY CCMP/ SHEFFIELD. The wood is flat sided throughout and is decorated with file branding in diagonal lines. The enlarged butt is pierced for the attachment of three grizzly bear claws and a rawhide trailer onto which are sewed a number of brass trade bells.

L: $40^{\prime \prime}$

MAI/HF : I $4 / 2$ I 73

24. Peace wampum belt with trade tomahawk in purple and white quahag shell beads. It symbolizes the defeat of the Algonquians by the Iroquois in I670 and was presented by the victors to the vanquished at the council following the war. The belt is I5 rows wide with a hemp fiber weft and deer skin warp. At one time it was smeared with vermillion; the depiction of the simple iron hatchet upon it makes it an important document for this study. For a detailed identification and documentation of this early wampum belt see Keppler, (I929). It is $43 \frac{1^{\prime \prime}}{}{ }^{\prime \prime}$ long and varies from $4 \frac{1{ }^{\prime \prime}}{}$ ' to $4 \frac{12^{\prime \prime}}{}$ wide.

MAI/HF : 9776

\section{SIMPLE HATCHETS AND BELT AXES}

25.-34. Group of simple hatchets or belt axes of the commonest form with rounded polls, showing some of the variety in size and shape that may be found in even so basic a type. No. 25 is the large size, typical of those traded almost exclusively during the $\mathbf{I} 7$ th century and gradually replaced by lighter varieties after $\mathbf{1} 700$, until they were relegated to the position of the "squaw axe". (H: $7^{\prime \prime} \mathrm{W}: 3 \frac{1}{2}$ "). Most are made in the usual fashion, from one piece of strap iron with a steel edge welded on. Exceptions are No. 32, which is hammered out of brass and may be of Indian manufacture. $\left(\mathrm{H}: 5^{\prime \prime}\right.$ W: $\left.2 \frac{1{ }^{\prime \prime}}{2}\right)$; and No. 34 , from New Hampshire, which was made in two sections and welded down the middle. It is entirely of iron without a steel edge. $\left(\mathrm{H}: 7^{\prime \prime} \mathrm{W}: 2 \frac{1^{\prime \prime}}{}{ }^{\prime}\right)$.

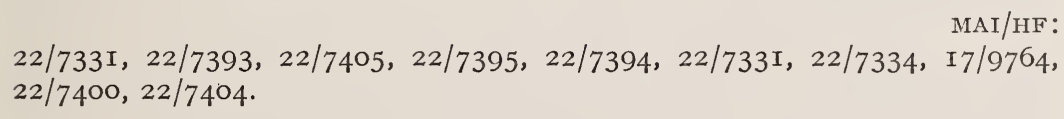

MAI/HF :

22/733I, 22/7393, 22/7405, 22/7395, 22/7394, 22/733I, 22/7334, I7/9764, $22 / 7400,22 / 7404$.

35.-37. Anglo-American belt axes of the mid-I8th century found at Fort Ticonderoga. They resemble the contemporary felling axe as it was developing in America, but are quite small in size. These particular specimens were probably used by colonial soldiers. The polls are flat and slightly thickened on 35 and 36 but not enough as yet to counter-balance the weight of the blade and prevent wobbling in a stroke. The poll of No. 37 is also flat but not thickened. The eyes are long thin teardrops on numbers 35 and 36 , and are slightly shorter and thicker on 37. In all instances, the eyes flare to the rear rather than to the front as was usual in most tomahawks. Note that ears have developed on 35 and 36. No. 35 bears an illegible maker's mark on the reverse side.

No. $35: \mathrm{H}: 4^{\frac{3}{4}}$ " W: $3^{\prime \prime}$

No. $36: \mathrm{H}: 3^{\frac{3}{4}}{ }^{\prime \prime} \mathrm{W}: 2 \frac{5}{8}^{\prime \prime}$

No. $37: \mathrm{H}: 3 \frac{3^{\prime \prime}}{4} \mathrm{~W}: \mathrm{I}^{\frac{7}{8}}{ }^{\prime \prime}$

Author's collection 
38. Iron hatchet with double flaring blade and steel edge, middle 18 th century. Excavated in an Indian grave near Greenwich, Conn. The flat poll is not thickened and shows signs of having been used for pounding. The eye is rectangular. On the obverse side is a maker's mark consisting of a depressed oval with a raised border of dots and, in the center, crossed saws or scythe blades above a star. There were originally three letters in the angles formed by the saws, but only $\mathrm{H}$ and $\mathrm{A}$ are now legible. Hatchets of this form are comparatively rare.

$\mathrm{H}: 5^{\prime \prime} \mathrm{W}: 4^{\frac{1}{4}}$

Ben F. Hubbell collection

39. Hatchet of the so-called "Spanish Southwestern form." Note the three-piece construction with the two side pieces of iron welded together above the eye to form a heavy crest and the steel edge welded on. Collected in Albuquerque, New Mexico.

$\mathrm{H}: 3 \frac{7}{8}^{\prime \prime} \mathrm{W}: \mathrm{I}^{3^{\prime \prime}}$

William O. Sweet collection

40. Fully developed hatchet of the American type, period I 750-1850. The heavy poll now counter-balances the blade. The ear is pronounced, and the eye is an elongated teardrop much the same as in a modern hatchet.

$\mathrm{H}: 4^{\prime \prime} \mathrm{W}: 2^{\prime \prime}$

William O. Sweet collection

41. An unusual double-edge hatchet of unknown provenience; the haft is probably recent. The head is made of four pieces-two iron sides and two steel edges, and it apparently dates from the mid-Igth century. The eye is oval.

$\mathrm{H}: 3 \frac{3{ }^{\prime \prime}}{}{ }^{\prime \prime} \mathrm{W}: 2 \frac{3^{\prime \prime}}{8} \mathrm{~L}: \mathrm{I}^{\prime \prime}$

$\mathrm{MAI} / \mathrm{HF}: 22 / 7243$

42. Late belt axe of the traditional pattern with rounded poll and teardrop eye, (ca. I850-1860). The head is apparently English and bears a maker's mark on the reverse side. This is now illegible except for the words "CAST STEEL/WARRANTED." A separate steel edge is welded on. The head is well made with filed borders around the eye; moldings are below it. The wooden haft is encased at the butt end in buckskin and bears beaded decoration plus fringes and a buckskin wrist loop. Collected about I 875 from the Teton Sioux.

$\mathrm{H}: 6 \frac{1}{4}^{\prime \prime} \mathrm{W}: 3 \frac{14^{\prime \prime}}{4} \mathrm{~L}: 24 \frac{34^{\prime \prime}}{4}$

$\mathrm{MAI} / \mathrm{HF}: 9 / 6588$

43. A traditional belt axe of the I8th or early I9th century with rounded poll and round eye. It is made of wrought iron with a steel edge. On the obverse side are two stamped marks consisting of a pair of sunbursts connected by an arc. The wooden haft is mid-Igth century and is encased at the butt end with buckskin to which is attached a beaded and fringed flap. Attributed to the Oglala Sioux.

$\mathrm{H}: 5 \frac{1}{2}^{\prime \prime} \mathrm{W}: 2 \frac{3^{\prime \prime}}{8} \mathrm{~L}:$ I9 $\frac{1}{2}^{\prime \prime}$

$\mathrm{MAI} / \mathrm{HF}: 2 / 3 \mathrm{I} 78$

44. Late belt axe with exceptionally heavy flat poll. The eye is a pointed ellipse, and there is a stamped maker's mark that is now illegible. The wooden haft is wrapped just behind the head with strips of red cloth, and there is a wrist thong at the butt end. This specimen is of Crow provenience and probably dates from the second half of the Igth century.

$\mathrm{H}: 5 \frac{11}{4}^{\prime \prime} \mathrm{W}: \mathrm{I}_{4}^{\frac{3}{4}} \mathrm{~L}: 24^{\prime \prime}$

$\mathrm{MAI} / \mathrm{HF}: 2 / 3299$

45. Late belt axe by Collins \& Company. The shape is generally traditional, but the poll is flat and considerably thickened. The reverse side is stamped 
“No. I79/COLLINS \& CO. HARTFORD/CAST-STEEL WARRANTED." The wooden haft is decorated with file branding in wide bands, fur, feathers, and wool thread. It is Sioux, and dates from the latter part of the Igth century.

$\mathrm{H}: 5 \frac{3^{\prime \prime}}{4} \mathrm{~W}: 3 \frac{1}{2}^{\prime \prime} \mathrm{L}: 28 \frac{1}{2}^{\prime \prime}$

Smithsonian Institution

USNM : I5402 I

\section{MISSOURI WAR HATCHETS}

46. Missouri War Hatchet of the typical form, without piercings. The head is well made of a single piece of wrought iron, and the edge has been beveled, although there is no sign that it was ever sharpened. The eye is round, and there are deep file lines forming borders over the poll. The blade is decorated with stamped X's, plus a central design which resembles a stick figure drawing composed of sunbursts or "stars," and file stamped designs. The wooden haft is carved with a series of line-and-dot bands. The butt end is encased in buckskin with a black-and-white beaded band and flap. Most of the original fringe on the flap is now missing. Collected in I 870 from the Osage.

$\mathrm{H}: 8 \frac{3}{8}^{\prime \prime} \mathrm{W}: 5^{\prime \prime} \mathrm{L}: \mathrm{I} 6 \frac{1}{2}^{\prime \prime}$

$\mathrm{MAI} / \mathrm{HF}: 708 \mathrm{O}$

47. Missouri War Hatchet with cloth-wrapped haft. The head is well forged and slightly heavier than usual. The eye is round, and over the poll are file lines forming a border, plus a series of punched dots. There is a stamp which may be a maker's mark somewhat resembling a fleur-de-lys that has been applied five times. There are five circular holes in the blade, plus a sixth which has been filled with brass. The haft is encased in red woolen cloth terminating in a flap with the usual white selvage. The forward end of the haft is studded with brass tacks, and the lower edge of the butt is carved in serrations. Collected from the Osage.

$\mathrm{H}: 8 \frac{1^{\prime \prime}}{}{ }^{\prime \prime} \mathrm{W}: 4 \frac{5}{8}^{\prime \prime} \mathrm{L}: 24 \frac{1}{4}^{\prime \prime}$

MAI/HF : $2 / 895$

48. Missouri War Hatchet. The head is simple and plain except for a single piercing of a paisley or apostrophe shape. The eye is round. The wooden haft is completely unadorned, though there is a piercing for a wrist thong at the butt. Attributed to the Sisseton Sioux.

$\mathrm{H}: 7 \frac{1}{2} \mathrm{~W}: 5 \frac{3}{8} \mathrm{~L}: 23$

MAI/HF : $9 / 7365$

49. Missouri War Hatchet. This specimen is unusual because of its narrow edge in proportion to the height. Also, the edge has been sharply beveled, which is most uncommon. The eye is round, and the one-piece construction is typical. There are file line decorations over the poll and at the base of the blade, plus three rows of punched dots. The blade is pierced with a "bleeding heart" surrounded by a border of punched dots. The small projection to the rear at the base of the blade is more highly developed than is usually encountered in this form of hatchet. The wooden haft, which appears somewhat more recent than the head, is encased at the butt end in buckskin, with a black-and-white beaded band at the forward end and a flap at the rear. The handle section is wrapped with cord. Both ends of the leather are fringed, and decorated with tin-cone "danglers" enclosing tufts of deer hair. Collected from the Comanche.

$\mathrm{H}: 8^{\prime \prime} \mathrm{W}: 4^{\prime \prime} \mathrm{L}: 23^{\prime \prime}$

MAI/HF : II $/ 8057$ 
50. Missouri War Hatchet. The head itself is simply forged in the usual manner, but is decorated more elaborately than normal. There are file mark borders on the poll. The blade is pierced with a "bleeding heart," and just below the piercing on the obverse side are a crescent and a star inlaid in brass. Beneath the inlaid star are four punched stars. The haft is studded on the forward end with brass tacks and is completely wrapped in strouding. cloth. This covering consists of a broad strip of red wool and a narrower strip of blue wool which have been sewed together. At the butt end the strips separate and form two flaps with serrated edges. The blue strip terminates with selvage striping and the butt end of the haft is serrated on the under side and is pierced for a thong from which is suspended a cluster of small brass bells and two trimmed feathers. Collected from the Osage.

$\mathrm{H}: 8^{\prime \prime} \mathrm{W}: 4^{\frac{3}{4}}$

$\mathrm{MAI} / \mathrm{HF}: 2 / 9 \mathrm{I} 73$

51. Missouri War Hatchet of exceptionally large size. The huge head is decorated with deeply filed lines over the poll, plus moldings at the base of the blade. Punched dots form a cluster at the base of the blade and borders along its front and back, as well as around the piercings. These piercings consist of a heart in the center and two sunbursts, one at the leading edge and one at the heel. The edge has never been beveled. The plain wooden haft is studded with brass tacks. It is pierced for a thong from which a large brass bell is suspended. An almost identical hatchet is in the collections of the American Museum of Natural History. Collected from the Osage.

$\mathrm{H}: 9 \frac{3}{8}^{\prime \prime} \mathrm{W}: 6^{\prime \prime} \mathrm{L}: 2 \mathrm{I}^{\prime \prime}$

MAI/HF : $2 / 5036$

\section{SPONTOON TOMAHAWKS}

The great majority of spontoon tomahawks were made with pipes. A selection of these are illustrated and described in numbers $258-298$.

52. Spontoon axe of the type found among the Mandans by Lewis and Clark in 1805 and described by them as the "older fassion." The huge blade is forged from one piece of wrought iron, bent around to form the eye and welded at the base of the blade. The two basal processes were cut from the body of the blade and curled outward. The sole decoration consists of two circular piercings. Because of these typical piercings, the round eye, and the great length of this form of blade ( 12 to 15 inches in height), they are often mistaken for door hinges. As weapons they must have been extremely unwieldy especially since the haft was only about I 4 inches long, approximately equal to the height of the blade. The present specimen bears a maker's mark in the form of a capital L stamped at the base of the blade just below the weld.

$\mathrm{H}: \mathrm{I} \frac{1}{2}^{\prime \prime} \mathrm{W}: 3^{\frac{1}{4}}$

Donald Baird collection

53. Spontoon axe, (ca. 1830-1850). It is forged from a single piece of wrought iron in the usual fashion with a round eye. Decoration is provided in the form of numerous file marks and punched dots on both the blade and poll. The wooden haft is decorated with a few brass tacks just behind the head and wrapped with a coil of fur. Provenience unknown.

$\mathrm{H}:$ II $\frac{1}{2}^{\prime \prime} \mathrm{W}: 2 \frac{1}{2}^{\prime \prime} \mathrm{L}: 22^{\prime \prime}$

Smithsonian Institution USNM : 359628 


\section{HALBERD TOMAHAWKS}

Two other halberd tomahawks, both bearing pipe bowls, are described and illustrated as Numbers 107 and 108. Another closely related specimen is No. 6I, although it does not have a spear point.

54. Halberd tomahawk, probably New England, (ca. I700-I750). In many ways this unusual specimen seems almost to have been made from a halberd with the head and ground iron separated only by 2 inches of bare wood. Both head and ground iron are made of wrought iron and forged in several pieces. The blade and beak or spike are of one piece. The spear point is round in cross-section, and both it and the socket for the haft may at one time have screwed into the blade-beak combination. At the present, however, the piece is rusted badly so that it is not possible to determine whether this is the case or whether all three pieces were welded together.

$\mathrm{H}: 6 \frac{5}{8}^{\prime \prime} \mathrm{W}: 2 \frac{5^{\prime \prime}}{8} \mathrm{~L}: \mathrm{I} 3 \frac{\frac{1}{2}^{\prime \prime}}{}$

$\mathrm{MAI} / \mathrm{HF}: 22 / 724 \mathrm{I}$

55. Unusual halberd tomahawk, probably designed for throwing, (ca. I 825-I 850). The distinctive features of this specimen are the flat section of the haft and the sharply pointed butt filed to a distinct median ridge. It is impossible to determine without X-rays whether it was forged from two or three pieces of steel, but the haft and spear point seem to be one piece while the blade and beak have been welded on either as a unit or as separate pieces. The hole through the butt end of the haft is recent. Originally the pointed butt may have been driven into a short wooden handle. The fact that the dark green paint with which most of the piece was originally covered stops at the filed area of the butt seems to confirm this theory. No exact analogy for this tomahawk has been found, though it closely resenbles some medieval throwing axes. It is well made, however, and seems to have been designed as a weapon: its combination of points and edges makes it especially adaptable for throwing. Provenience unknown.

$\mathrm{H}: 6 \frac{1}{2}^{\prime \prime} \mathrm{W}: 4 \frac{3^{\prime \prime}}{8} \mathrm{~L}: 14 \frac{5}{8}{ }^{\prime \prime}$

Author's collection

56. Halberd tomahawk, probably New England, ( $c a$. I700-I750). It is forged from one piece of steel averaging three-sixteenths of an inch thick and is unusual in that it has a short chisel-like edge instead of a spear point. The short tang was designed to be driven into a wooden haft. The beak has been blunted somewhat from pounding, and there are still traces of yellow and red ochre on the blade.

$\mathrm{H}: 7^{\prime \prime} \mathrm{W}: 3 \frac{1^{\prime \prime}}{2} \mathrm{~L}: 5 \frac{3}{4}^{\prime \prime}$

William O. Sweet collection

57. Halberd (or halberd tomahawk) from New York State, (ca. I 70oI750). In some instances it is difficult to determine whether specimens such as this were designed to be fitted with a long haft to serve as halberd or whether they were meant to have short hafts and to be used as tomahawks. Probably some were finished one way and some another. The present specimen was found between the walls of a I7th century house in Kingston, N.Y., along with other pieces of Indian trade goods, such as packets of jews' harps and folding knives. It is forged from one piece of steel. The blade and spear point are sharpened, but the beak is simply a hook, rectangular in section. The end of the tang has been roughened with chisel cuts to help hold it in place after insertion in a wooden haft.

$\mathrm{H}: 8^{\prime \prime} \mathrm{W}: 5^{\prime \prime} \mathrm{L}$ : $15 \frac{1}{4}^{\prime \prime}$

Author's collection 
58. Halberd tomahawk, (ca. I 700-I 750). This a most important specimen, for it illustrates how heads such as number 57 were hafted for use as tomahawks. The head is forged as one piece with a long shank. Both blade and spear point have been sharpened, but the beak is one-eighth of an inch thick along its edge. It does, however, taper toward its apex to form a relatively sharp point. The original haft is slotted to receive the shank, which is secured in place by three transverse rivets with diamiond-shaped iron washers. An iron collar is wrapped around the fore end of the haft and brazed. The butt end is cut square, and apparently this is the original length of the haft. At any rate, it is far too slender ever to have been much longer. Provenience unknown.

$\mathrm{H}: 9 \frac{5}{8}^{\prime \prime} \mathrm{W}: 6 \frac{1}{2}^{\prime \prime} \mathrm{L}: 22 \frac{1}{2}^{\prime \prime}$

Author's collection

59. Halberd tomahawk, New England, early i8th century. Somewhat smaller than the preceding specimen, this piece seems more likely to have been used as a tomahawk than as a halberd, though either function is possible. It is forged from one piece of steel, one-quarter inch thick. This maximum thickness is maintained in the shank just before and behind the blade and beak, and tapers from that in both directions. The barbed spear point set far up the shank is a most unusual feature, and the beak is sharpened to an edge on the concave side. The tang is also sharpened to facilitate driving into a wooden haft.

$\mathrm{H}: 6^{\prime \prime} \mathrm{W}: 2 \frac{1^{\prime \prime}}{}{ }^{\prime \prime} \mathrm{L}: 12 \frac{1}{8}^{\prime \prime}$

Author's collection

60. Halberd tomahawk from Illinois, (ca. I 750). It is made entirely of wrought iron or low grade steel. The haft is round in section and swells at the normal position for grasping with the hand, then tapers to a blunt point. The beak has been broken off. A generally similar tomahawk marked by R. Beatty of Pennsylvania is said to have been owned by Daniel Boone. $\mathrm{H}: 3 \frac{5}{8}^{\prime \prime} \mathrm{W}: 2 \frac{1}{2}^{\prime \prime} \mathrm{L}: 13 \frac{1}{2}^{\prime \prime}$

$\mathrm{MAI} / \mathrm{HF}: 22 / 727 \mathrm{O}$

\section{SPIKED TOMAHAWKS}

One other spiked tomahawk is illustrated and described as No. 300 in the section on hatchets used by the military. Closely related types are also to be found illustrated in the sections on celtiform tomahawks and on naval boarding axes.

61. Early spiked tomahawk from Pennsylvania, very similar to the halberd type. This specimen, which dates from the first half of the I8th century, however, never had a spear point. It is forged in two pieces (head and haft) of wrought iron or low grade steel. The symmetrical, crescentic blade such as found on this and the succeeding three axes seems most often to be found in New York State, but it also occasionally appears in neighboring Pennsylvania and New England. The haft is flat sided with the corners rounded and sharply pointed at the butt.

$\mathrm{H}: 6 \frac{1}{2}^{\prime \prime} \mathrm{W}: 3 \frac{5}{8}^{\prime \prime} \mathrm{L}: 10 \frac{3}{8}{ }^{\prime \prime}$

$\mathrm{MAI} / \mathrm{HF}: 6 / 7608$

62. Early spiked tomahawk with crescentic blade from New York, (ca. I 730-I 760). It is forged in the usual manner with two pieces of wrought iron and a steel edge. The eye is round, and the blade, eye section, and spike are covered with decorations composed of punched circles plus straight lines 
and chevrons made up of many individual short lines. The spike is leaf shaped and double edged but has never been sharp.

$\mathrm{H}: 7 \frac{1}{2}^{\prime \prime} \mathrm{W}: 3 \frac{5}{8}^{\prime \prime}$

MAI/HF : $21 / 6289$

63. Early spiked tomahawk with crescentic blade from Ontario County, New York, (ca. I730-1 760). The eye is rectangular, and the entire head has been forged in the usual manner with a steel edge. The diamond-shaped spike has never been sharpened.

$\mathrm{H}: 6 \frac{3^{\prime \prime}}{4} \mathrm{~W}: 4 \frac{11}{4}^{\prime \prime}$

MAI/HF: IO/4I 70

64. Early spiked tomahawk with crescentic blade from Vermont, (ca. I730-I760). This one is of the more common form, designed for a wooden haft and having a rectangular eye. It is forged in two pieces in the typical fashion for a spiked axe plus a steel edge. The spike is sharpened along its back edge.

$\mathrm{H}: 5 \frac{1}{8}^{\prime \prime} \mathrm{W}: 2 \frac{3^{\prime \prime}}{8}$

MAI/HF : 6/6402

65. Spiked tomahawk from New York State, (ca. I750). It is made of wrought iron with a steel edge. The eye is a pointed ellipse, almost diamond shaped. The spike is rectangular in section and has been decorated with notches cut in the angles.

$\mathrm{H}: 5 \frac{14^{\prime \prime}}{\mathrm{W}}: 2 \frac{1}{2}^{\prime \prime}$

$\mathrm{MAI} / \mathrm{HF}: \mathrm{I9} / 4 \mathrm{I} 8$

66. Spiked tomahawk from Genoa, New York, (ca. I750). It is forged from iron with a steel edge. The spike has a strong median ridge on both sides so that it is roughly diamond shaped in section. The eye is rectangular. $\mathrm{H}: 7 \frac{1}{4}^{\prime \prime} \mathrm{W}: 3^{\prime \prime}$

MAI/HF: $5 / 4599$

67. Spiked tomahawk from New York State, mid-I8th century. The curved spike is especially long in relation to the size of the blade. It is rectangular in section at the base, and gradually becomes rounder as it tapers to the point. The eye is oval, and there is a steel edge.

$\mathrm{H}: 7 \frac{1}{2}^{\prime \prime} \mathrm{W}: \mathrm{I}^{\prime \prime \prime}$

MAI/HF : $21 / 6303$

68. Exceptionally large spiked tomahawk, I8th century. The eye is rectangular, and the spike is round in section. There is no information concerning provenience.

$\mathrm{H}: 10 \frac{1}{2}^{\prime \prime} \mathrm{W}: 3 \frac{1}{4}^{\prime \prime}$

MAI/HF : 22/7337

69. Very large spiked tomahawk from New York State with symmetrically developed ears and a straight spike, possibly i 8 th century. The spike is rectangular in section with rounded corners at the base, but quickly becomes round. The eye is oval.

$\mathrm{H}: \mathrm{IO} \frac{1}{2}^{\prime \prime} \mathrm{W}: 3^{\frac{3}{4}}{ }^{\prime \prime}$

$\mathrm{MAI} / \mathrm{HF}: 22 / 7407$

70. Spiked tomahawk of a form closely related to No. 65 , but half again as large; mid-I8th century. The spike is rectangular in section, but the edges are chamfered. The eye is oval. Provenience is unknown.

$\mathrm{H}: 8 \frac{1}{4}^{\prime \prime} \mathrm{W}: 3 \frac{1 \frac{1}{2}^{\prime \prime}}{}$

MAI/HF : 22/7337

71. Spiked tomahawk, I8th century. The spike is unusual in that it is triangular in section. The eye is oval, and the blade has been cut off at the back so that the edge is quite narrow. Provenience unknown.

$\mathrm{H}: 5 \frac{1{ }^{\prime \prime}}{2} \mathrm{~W}: \mathrm{I} \frac{5^{\prime \prime}}{}$

MAI/HF : 22/7337 
72. Late spiked tomahawk collected among the Seneca in Oklahoma. It appears to be no earlier than the second quarter of the rgth century, well after the vogue for this form of tomahawk had passed. It is made of wrought iron with a steel edge. The eye is a pointed ellipse, and the spike is rectangular in section.

$\mathrm{H}: 7^{\frac{3}{8}} \mathrm{~W}: 3^{\prime \prime}$

$\mathrm{MAI} / \mathrm{HF}: 20 / 7293$

73. Late spiked tomahawk, probably I800-I8Io, said to have been found on the Tippecanoe battlefield in Indiana. The spike is rectangular in section, and the eye is oval.

$\mathrm{H}: 8^{\prime \prime} \mathrm{W}: 2 \frac{3^{\prime \prime}}{4}$

MAI/HF : $22 / 739$ I

74. Spiked tomahawk from Connecticut with symmetrical ears and symmetrically flaring blade, ( $c a$. I 740-I 770 ). The eye is a pointed ellipse. The spike is rectangular in section with the corners chamfered at the base and gradually tapering out for about three quarters of its length.

$\mathrm{H}: 7 \frac{3}{8}^{\prime \prime} \mathrm{W}: 3 \frac{1}{8}^{\prime \prime}$

Ben F. Hubbell collection

75. Spiked tomahawk with original haft, (ca. I 740-I 770). This specimen is believed to have come from the Mohawks of central New York State. It is very similar to one carried by a colonial soldier during the French wars and now in the Rhode Island Historical Society. The spike is generally rounded in section, and the eye is oval. The wooden haft still bears traces of red paint. $\mathrm{H}: 6 \frac{7}{8}^{\prime \prime} \mathrm{W}: 2 \frac{1^{\prime \prime}}{8} \mathrm{~L}: \mathrm{I} 7^{\prime \prime}$

William O. Sweet collection

76. Spiked tomahawk with exceptionally long haft. The head is beautifully forged with moldings at the base of the spike, and engraved scroll and line decoration over the eye and down the blade. The spike has a low median ridge and slopes to an edge both front and back, but it has been cut away at the forward end to allow it to pass through the eye, and the wood which protrudes has been hammered out so that the haft is in a sense "riveted" in place. The wood has been wrapped and burned in a tiger stripe design with one broad and one narrow stripe spiralling around it. During the years it has broken once, approximately in the middle, and been repaired. This is one of few the specimens with such a long haft, and the presumption is that it was designed as a ceremonial present during the second half of the I8th century. It was found in Pennsylvania.

$\mathrm{H}: 7{ }^{\prime \prime \prime} \mathrm{W}: 2^{\prime \prime} \mathrm{L}: 35 \frac{1^{\prime \prime}}{2}$

Author's collection

77. Spiked tomahawk with unusually forged head and conical cap at the butt, (ca.I 740-I 760). Instead of being forged in the usual manner from two pieces of iron welded together above and below the eye, this specimen appears to have been made from a piece of iron wrapped around a form for the eye and then welded back upon itself in the manner of the typical belt axe with rounded poll. The spike was then forged separately and welded on. There is also a steel edge. At the base of the spike is a flat molding to supply the welding area, and this has been balanced by additional moldings on the poll and below the eye. The spike is straight sided for most of its length with chamfered corners; then it tapers rapidly to a point and becomes rounded in section. The eye is round. The wooden haft is straight sided until it enters the butt cap, and there it tapers rapidly to a point. The butt cap is made of sheet iron and resembles the ground iron of a polearm of the period. Obtained from the Iroquois.

$\mathrm{H}: 6^{\prime \prime} \mathrm{W}: \mathrm{I} \frac{7^{\prime \prime}}{8} \mathrm{~L}: \mathrm{I} 4^{\prime \prime}$

MAI/HF : 2O/I993 
78. Spiked tomahawk of the late I8th or early I9th century, of unknown origin. The head is well made and heavier than usual. The eye is a pointed ellipse, and there are engraved line-and-chevron decorations above and below the eye and on the spike. The spike itself has a strong median ridge, but the edges were never really sharp. The haft is modern.

$\mathrm{H}: 8 \frac{3}{4}^{\prime \prime} \mathrm{WV}: 2 \frac{1}{8}^{\prime \prime} \mathrm{L}: 28^{\prime \prime}$

MAI/HF : $22 / 7237$

79. Late spiked tomahawk made by Goulding \& Company, New York, (ca. I850-1860). The head is made of steel and finely finished with an oval eye and a spike with a high median ridge. The haft is of the curved pattern which became popular about the middle of the Igth century for both hatchets and axes. On both the butt and fore end are brass plates, each attached by two screws. The butt plate is stamped "GOULDING \& CO/ NEW YORK;" the front plate "GOULDING / NEW YORK." This firm made surgical instruments and other fine cutlery during this period. It is attributed to the Iroquois.

$\mathrm{H}: 8 \frac{3}{4}^{\prime \prime} \mathrm{W}: 4 \frac{1}{2}^{\prime \prime} \mathrm{L}: \mathrm{I} 7^{\prime \prime}$

$\mathrm{MAI} / \mathrm{HF}: \mathrm{I}_{5} / 6258$

80. Late spiked tomahawk, ( $c a .1840-1850$ ). The long straight spike is generally rectangular in section. The eye is wedge shaped, and there is a well-developed socket for the haft. The edge of the blade is somewhat broken, but there is no indication of any steel. The haft is straight and undecorated. Attributed to the Sioux.

$\mathrm{H}: 10^{\prime \prime} \mathrm{W}: 2 \frac{1}{2}^{\prime \prime} \mathrm{L}: 26 \frac{7^{\prime \prime}}{8}$

MAI/HF : $2 / 5325$

81. Spiked tomahawk with brass head, late I9th or early 20 th century. The head is crudely cast. The eye is round, the diameter increasing towards the haft which is apparently held in place by friction only. The haft itself expands similarly. Slightly more than half way to the butt it is pierced for a rawhide thong, which is decorated with thread wrapping, short strips of fur, and a long tuft of horsehair. Tribal origin unknown.

$\mathrm{H}: 5^{\prime \prime} \mathrm{W}: 3 \frac{5^{\prime \prime}}{8} \mathrm{~L}: \mathrm{I} 7 \frac{1}{2}^{\prime \prime}$

MAI/HF : $22 / 7236$

82. Late spiked tomahawk of unusual construction, (ca. I850-1860). Both the blade and the spike are formed from sheets of steel. These are fastened together by two straps of iron which are bent outward in the space between, to form the eye, which is in the shape of a pointed ellipse. The haft is copied from the recurved axe and hatchet handles which became popular after the middle of the century. Attributed to the New York Seneca.

$\mathrm{H}: 8 \frac{1}{4}^{\prime \prime} \mathrm{W}: 3 \frac{5^{\prime \prime}}{8} \mathrm{~L}: 19^{\prime \prime}$

MAI/HF : I $4 / 4984$

83. Spiked tomahawk with symmetrically flaring blade, (ca. late I8th or early I9th century). Note the resemblance to No. 69, except that the spike on this specimen is bent and is slightly shorter. The spike is rectangular in section at the base but quickly becomes rounded. The eye is oval. The haft is a modern replacement. Provenience unknown.

$\mathrm{H}: 8 \frac{1}{2}^{\prime \prime} \mathrm{W}: 5^{\prime \prime}$

MAI/HF : $22 / 7264$

84. Spiked tomahawk, late I 9 th or early 20 th century. The spike is rectangular in section. The eye is oval. The haft is even more recent than the head. Provenience unknown.

$\mathrm{H}: 8^{\prime \prime} \mathrm{W}: 2 \frac{1^{\prime \prime}}{4} \mathrm{~L}: 19 \frac{7}{8}^{\prime \prime}$

MAI/HF : $22 / 7245$ 
85. Spiked tomahawk, (ca. I890-I9Io). The construction of this specimen is most unusual. The poll is wrought iron, and the blade is attached to it by three rivets. Inside the eye and around the haft is a short section of iron pipe. The spike seems to be riveted on. The haft is decorated with brass tacks, brass bands, a black leather band, and blue-and-white beaded bands. Tribal affiliation unknown.

$\mathrm{H}: 7 \frac{1}{4}^{\prime \prime} \mathrm{W}: 2 \frac{1}{2}^{\prime \prime} \mathrm{L}: \mathrm{I} 6 \frac{1}{4}^{\prime \prime}$

$\mathrm{MAI} / \mathrm{HF}: 22 / 7250$

86. Spiked tomahawk, late Igth century. The piece is functional as a weapon, which is unusual in an implement which seems to be so recent from the standpoint of style and workmanship. The spike is rectangular in section, and the eye is a flat oval. Provenience unknown.

$\mathrm{H}: 7 \frac{1}{4}^{\prime \prime} \mathrm{W}: 2 \frac{1}{2}^{\prime \prime} \mathrm{L}: \mathrm{I} 6 \frac{1}{4}^{\prime \prime}$

$\mathrm{MAI} / \mathrm{HF}: 22 / 73 \mathrm{IO}$

87. Spiked tomahawk of cast iron, 2oth century. The form of the blade owes much to the Missouri war hatchet except that the poll is flat on top and that the sides of the blade flow from the poll to the edge in a straight line instead of curving in beneath the eye. There is a pierced decoration in the form of a "bleeding heart." The eye is round, and the spike is round in section. All in all, this heavy and clumsy piece could serve only for decoration. The haft expands gradually from the head to the butt. It is pierced with a small hole near the butt, and two feathers are attached to a rawhide thong tied through the hole. Tribe unknown.

$\mathrm{H}: 7 \frac{7}{8}^{\prime \prime} \mathrm{W}: 4 \frac{1}{4}^{\prime \prime} \mathrm{L}: \mathrm{I} 6 \frac{3}{4}^{\prime \prime}$

MAI/HF : $22 / 7247$

88. Spiked tomahawk of cast iron, (ca. I890-I920). The eye is round, and the spike is generally rounded in section. On the obverse side of the blade is a simple incised decoration which was cast in the piece. It consists of a rectangle with two diagonal lines connecting the corners and forming an $\mathrm{X}$. The haft bears remnants of black paint and shows evidence of charring. Near the head it is pierced with a small hole from which are suspended a short string of beads and a tuft of horsehair. Collected from the Chippewa. $\mathrm{H}: 7 \frac{1}{2}^{\prime \prime} \mathrm{W}: 2 \frac{3}{8}^{\prime \prime} \mathrm{L}: \mathrm{I} 6^{\prime \prime}$

$\mathrm{MAI} / \mathrm{HF}:$ I I/8I 58

\section{TOMAHAWKS WITH HAMMER POLLS}

Other tomahawks with hammer polls which are believed to have been used by settlers are illustrated and described as numbers 302, 305, 307. One tomahawk which can be converted from a pipe to a hammer with a threaded insert is illustrated and described as No. 2 I 5 .

89. Unique tomahawk with hammer poll, probably second half of the I 8 th century. It is made entirely of wrought iron, and it is an exceptionally good forging. The eye itself is round, but the metal surrounding it has been brought out to a ridge, giving this portion of the axe a diamond shape when viewed from the front. On the poll is mounted a tall finial with a thin vertical base from which a cylindrical column rises to a button at the top. Moldings are forged and filed around the column, and there are straight file line decorations on the base which is also pierced with a single circular hole. The blade is quite thin, and it also is pierced in an intricate pattern featuring a four-pointed star. In addition, there are straight horizontal file lines and punched dots all over the poll and around the eye. Along the edge on the 
reverse side of the blade is a line of small stamped sunbursts. The haft is modern. The axe is believed to have been made in New England.

$\mathrm{H}: 6 \frac{3^{\prime \prime}}{8} \mathrm{~W}: 3 \frac{1}{2}^{\prime \prime} \mathrm{L}: \mathrm{I} 5^{\prime \prime}$

$\mathrm{MAI} / \mathrm{HF}: \mathrm{I} 5 / \mathrm{I} 63$

90. Tomahawk with hammer poll, mid-I8th century, probably from New York or New England. Tomahawks with hammers are relatively scarce, but this is the size and shape most often encountered during the early period when they were often an object of real use. It is forged in three pieces in the manner most commonly used for spiked tomahawks. Two pieces of wrought iron were welded together above and below the eye, and a steel edge was sandwiched in. The eye is a pointed ellipse. The hammer is rectangular in section with the edges chamfered, giving almost an octagonal section.

$\mathrm{H}: 6 \frac{3^{\prime \prime}}{4} \mathrm{~W}: \mathrm{I}_{\frac{3}{4}}{ }^{\prime \prime}$

William $O$. Sweet collection

91. Superb tomahawk with hammer poll of the late $\mathrm{I} 8$ th century or very early I9th century. An identical specimen except for the engraving was recovered in Ohio some years ago and is now in the Ben Palmer collection. The eye is round. The hammer is round in section and enhanced with finely forged moldings. There is also a deep concave molding at the base of the blade to set it off from the eye area. On the reverse side of the blade is inlaid a silver crescent which once bore an Indian's name, now illegible. Above the inlay are engraved the letters S C, separated by a sunburst. Below, running in perpendicular lines, is engraved the motto "to your / arms solder / and fight." The haft is curly maple, much darkened. Provenience unknown.

$\mathrm{H}: 8^{\prime \prime} \mathrm{W}: 2 \frac{3{ }^{\prime \prime}}{4} \mathrm{~L}: 19 \frac{3}{8}^{\prime \prime}$

William Guthman collection

92. Tomahawk with a hammer poll of the mid-I8th century in better condition and exhibiting slightly better forging than No. 90. The eye is a thick oval. The hammer is almost a true octagon in section, although the wider base is rectangular and the top molding is almost circular. There are also moldings at the poll and just below the eye. From Cayuga County, New York. $\mathrm{H}: 6 \frac{1}{2}^{\prime \prime} \mathrm{W}: 2 \frac{3}{8}^{\prime \prime}$

Ben F. Hubbell collection

93. Late tomahawk with hammer poll, (ca. I850-1880). The eye is teardrop. The hammer is ten sided for most of its length, but terminates in a round band at the top. There are filed moldings above and below the eye. The haft is branded in stripes with a hot file and is studded for half its length with brass tacks arranged in four double bands and two single ones. There is a hole through the center of the haft at the butt, and through this are knotted two short strips of fur. Attributed to the Hunkpapa Sioux.

$\mathrm{H}: 6 \frac{3}{8}^{\prime \prime} \mathrm{W}: 2^{\prime \prime} \mathrm{L}: 23^{\frac{1}{2}}{ }^{\prime \prime}$

$\mathrm{MAI} / \mathrm{HF}: 20 / 1302$

94. Late tomahawk with hammer poll, (ca. I860-1890). The eye is oval. The hammer is generally octagonal with moldings at top and bottom. Additional moldings are filed above and below the eye, and two deep file lines form an $\mathrm{X}$ across this area. The blade flares symmetrically with straight sides and is quite thin, which is typical for most forms of tomahawk from this period; it is forged completely of steel. The wide wooden haft has been cut down to enter the eye, which is unusual. It is file branded and is studded with brass tacks arranged in conventional designs. The butt is wrapped in fur tied with rawhide thongs, and there is a blue, white, and black flap backed with cloth and terminating in a beaded buckskin fringe. Collected from the Crow.

$\mathrm{H}: 7 \frac{1}{2}^{\prime \prime} \mathrm{W}: 4 \frac{14^{\prime \prime}}{} \mathrm{L}^{\prime}: 20 \frac{1}{4}^{\prime \prime}$

$\mathrm{MAI} / \mathrm{HF}: \mathrm{I} 3 / 5320$ 
95. Late tomahawk with hammer poll, (ca. I850-1870). The eye is wedgeshaped, and the hammer, generally round in section, flares outward toward the top. The blade at one time was stamped with the number 2 with several words forming a circle around it. These are now illegible, however. The haft is branded with a file for slightly more than two-thirds of its length and is pierced for a thong at the butt. Attributed to the Sioux.

$\mathrm{H}: 6 \frac{1}{2}^{\prime \prime} \mathrm{W}: 2 \frac{1}{2}^{\prime \prime} \mathrm{L}: 25^{\prime \prime}$

$\mathrm{MAI} / \mathrm{HF}: 7 / 4629$

96. Tomahawk with hammer poll of the late $\mathrm{I} 8$ th or early I9th century. It is forged from two pieces of iron plus a steel edge. The eye is oval. The hammer is roughly octagonal. Provenience unknown.

$\mathrm{H}: 4^{\frac{3}{4}} \mathrm{~W}: 3^{\prime \prime}$

MAI/HF : $22 / 7336$

97. Tomahawk with hammer poll from Hamilton County, Indiana, late I8th century. It is made of wrought iron with a steel edge. The eye is oval, and the hammer is generally round in section. Numerous small dots have been punched into the metal as a decoration.

$\mathrm{H}: 4^{\frac{5}{8}}{ }^{\prime \prime} \mathrm{W}: \mathrm{I}^{\frac{5}{8}}{ }^{\prime \prime}$

$\mathrm{MAI} / \mathrm{HF}: 22 / 7402$

98. Tomahawk with hammer poll. It is made of wrought iron with a steel edge. The eye is oval. The hammer is generally round in section and flares outward towards the top. On the obverse is a maker's name, now illegible, stamped in a rectangular cartouche, below which are the large letters US of the form commonly used during the Revolution and immediately thereafter to denote government property. Therefore, it may well have been issued to troops or possibly given to friendly Indians, though the former is more likely. Compare with No. 302, another tomahawk with a hammer poll bearing what appear to be identical markings. This specimen was recovered in Ohio.

$\mathrm{H}: 5 \frac{1}{4}^{\prime \prime} \mathrm{W}: 2^{\prime \prime}$

MAI/HF : $22 / 7403$

99. Tomahawk with hammer poll, (ca. I860-I890). It is made of steel in the typical fashion for western tomahawks of the period, with thin straightsided blade flaring symmetrically. The eye is oval. The hammer is round in section, decorated with moldings and diagonal file lines. The blade is pierced with a heart design and further decorated with a diagonal line of punched dots. The haft is studded with brass tacks and branded with a file. The butt is pierced for a thong, and to it are attached two strips of fur. Attributed to the Chippewa.

$\mathrm{H}:$ Iо $\frac{1}{2}^{\prime \prime} \mathrm{W}: 4 \frac{3}{8}^{\prime \prime} \mathrm{L}: 23 \frac{3}{4}^{\prime \prime}$

$\mathrm{MAI} / \mathrm{HF}: \mathrm{I} 5 / 4742$

100. Tomahawk with hammer poll converted from a pipe tomahawk, (ca. I 860-1890). In this instance the pipe bowl was broken off, and a short hammer of lead was substituted. The rest of the head is steel, decorated with filed moldings below the eye and cross-hatched file lines at the base of the hammer. The eye is of teardrop form, and the blade is characteristically thin. The haft is studded with brass tacks and branded with a file. The butt is encased in buckskin with a thong at the rear, a beaded band, fringe, and a red cloth flap with a beaded panel at the forward edge. At the base of the beaded panel is a row of short tufts of hair fastened in small brass cones. Collected from the Shoshoni.

$\mathrm{H}: 8 \frac{1}{4}^{\prime \prime} \mathrm{W}: 3^{\frac{3}{4}}{ }^{\prime \prime} \mathrm{L}: 23^{\prime \prime}$

MAI/HF: $20 / 9754$ 
101. Tomahawk with hammer poll, probably a converted tool, (ca. I830I860). From all appearances this may well have been a shingler's or lather's hatchet before being acquired by the Wyandot of Ohio, from whom it was collected. It is made of wrought iron with a steel edge. The eye is a pointed ellipse, and the hammer is round in section. The haft is undecorated.

$\mathrm{H}: 5 \frac{1^{\prime \prime}}{}{ }^{\prime \prime} \mathrm{W}: 2 \frac{3^{\prime \prime}}{8} \mathrm{~L}: \mathrm{I} 2^{\prime \prime}$

MAI/HF : IO/2893

\section{CELTIFORM TOMAHAWKS}

102. Early celtiform tomahawk from Oklahoma. The use of iron for the blade and the apparent use of steel tools in fabricating the haft indicate that it is a post-contact specimen, but the workmanship suggests that the entire axe, including the head, is of Indian manufacture. The date is thus difficult to establish, but it would certainly seem to be in the early i 8 th century. The blade passes through the haft and is secured by two transverse rivets. The haft was originally painted a dull red and dark brown, almost black. On the forward end and over the blade is carved the figure of an otter, probably the dream helper which had appeared to the owner when he fasted for power as a youth, and from whom he hoped to acquire the facility for swift attack with which the otter was credited. The axe was found in the war bundle of an Iowa Indian in Oklahoma, and has been published by Harrington, (I920).

$\mathrm{H}: \mathrm{II} \frac{3^{\prime \prime}}{4} \mathrm{~W}: \mathrm{I}_{2}^{1{ }^{\prime \prime}} \mathrm{L}: 22^{\prime \prime}$

MAI/HF : $3 / 3877$

103. Early celtiform tomahawk from Mississippi. It is difficult to date so simple a specimen precisely, but the type of forging and the use of a shank seem to point to the 18 th century. The head is made in two pieces, a simple triangle with the apex slightly curved, with a narrow strap bent around it and welded to it and to itself to form a shank for driving into a wooden haft. This mode of construction causes it to resemble in outline the halberd forms also encountered during the 18 th century. The blade is well forged, and the apex is strengthened with a well-defined median ridge which gives it a diamond shape in section.

$\mathrm{H}: 6 \frac{1}{2}^{\prime \prime} \mathrm{W}: 3 \frac{3^{\prime \prime}}{}{ }^{\prime \prime}$

MAI/HF : 20/9797

104. Celtiform tomahawk hafted in rawhide collected from a Ponca Indian in $184^{\circ}$. The surface of the head is very rough, but the sides and angles are true and uniform, possibly indicating white manufacture. The butt is pierced for a thong which is still in place.

$\mathrm{H}: 6 \frac{3}{8}{ }^{\prime \prime} \mathrm{W}: 4^{\prime \prime} \mathrm{L}: \mathrm{I} 5 \frac{1}{4}^{\prime \prime}$

Woolaroc Museum: In D-452

105. Modern celtiform tomahawk suitable only for display purpose. The head is cut from thin sheet copper. The haft is split and lashed with sinew and leather which have been painted red and blue. Provenience unknown. $\mathrm{H}: 88^{\prime \prime} \mathrm{W}: 3^{\prime \prime} \mathrm{L}: 28^{\prime \prime}$

$\mathrm{MAI} / \mathrm{HF}: 22 / 7273$

106. Early celtiform tomahawk blade. It is forged in a single piece with the apex slightly curved in a manner similar to No. I03. Four circular piercings arranged to form a rectangle served either as decoration or as a means of securing the blade to the haft. Because of its early form and the fact that it was recovered near Hampton, Virginia, it would seem safe to assign it a date no later than the middle of the $\mathrm{I} 8$ th century.

$\mathrm{H}: 3 \frac{1}{2}^{\prime \prime} \mathrm{W}: 2 \frac{1}{2}^{\prime \prime}$

$\mathrm{MAI} / \mathrm{HF}: 22 / 7406$ 


\section{PIPE TOMAHAWKS}

Because pipe tomahawks are so numerous and diversified they have been divided into the following categories: halberd form, conventional blades, spontoon blades. Within these groups they are further divided by materials; first, those of iron and steel, those of brass with steel blades, those completely of brass or pewter, and finally those of stone, of which only a few specimens are included for comparison. It should be noticed also that a few pipe tomahawks are included in the section dealing with the white use of tomahawks.

\section{PIPE TOMAHAWKS OF THE HALBERD FORM}

107. Unusual halberd pipe tomahawk with an iron haft. The head is steel, probably with a shank which is inserted into the shaft underneath the forward silver band. The haft is made of sheet iron wrapped around and brazed. At both ends there are silver bands which have been wrapped and soldered. A butt cap and tubular mouthpiece of silver are also soldered in place. The pipe bowl can be unscrewed and removed. Halberd tomahawks are normally considered very early, but the design and workmanship on this specimen would seem to indicate a date no earlier than the first half of the Igth century. Provenience unknown.

$\mathrm{H}: 5 \frac{1^{\prime \prime}}{8} \mathrm{~W}: 3 \frac{7^{\prime \prime}}{8} \mathrm{~L}: \mathrm{1} 6 \frac{1}{4}^{\prime \prime}$

MAI/HF : $22 / 7230$

108. Halberd tomahawk with pipe bowl in place of the spike or beak; r 8 th century. The main body of the head is forged from iron, but there is a deep steel edge sandwiched and welded into the head. The spear point is pierced with a heart design. Opposite the spear point is a small threaded hole for attaching the haft. The general shape of the piece would indicate the area from Pennsylvania through New England, though the specimen was actually collected in the Southwest.

$\mathrm{H}: 4 \frac{3}{8}^{\prime \prime} \mathrm{W}: 4 \frac{5}{8}^{\prime \prime}$

Smithsonian Institution

USNM : 36918

\section{PIPE TOMAHAWKS WITH CONVENTIONAL BLADES}

\section{Iron or Steel Heads}

109. Superb example of a mid-I8th century pipe tomahawk. The head is inlaid in both brass and silver, and both the inlays and surrounding areas of the head are engraved. Around the center of the pipe bowl are a series of triangular silver inlays engraved with floral patterns. On either side of the base of the bowl where it is welded to the poll are shield-shaped brass inlays, again with floral designs engraved upon them. Silver 8-pointed stars with engraved borders suggesting vines are on both sides of the eye area. The blade bears brass triangles and a series of inlaid silver flowers connected by engraved stems and leaves cut into the iron of the head. The haft is curly maple with a shaped underside and mouthpiece. Provenience unknown.

$\mathrm{H}: 8 \frac{1}{4}^{\prime \prime} \mathrm{W}: 3^{\prime \prime} \mathrm{L}: 22^{\prime \prime}$

William $O$. Sweet collection

110. Pipe tomahawk of a slightly higher quality than No. III, and dating from the same era. The moldings on the head are more boldly executed, and the inlays in the haft are engraved with scratchwork designs. These inlays consist of a fore-end cap, a band just behind the head with serrated edges, and a mouthpiece also with serrated edges, all of pewter. In addition 
there are two bands plus a series of rectangular inlays in a low grade silver or very high quality pewter; these are held in place with small nails: The eye is large and teardrop in form. The haft is of the characteristic cigar shape. Provenience unknown.

$\mathrm{H}: 7 \frac{1}{2}^{\prime \prime} \mathrm{W}: 2 \frac{1}{4}^{\prime \prime} \mathrm{L}: \mathrm{I}_{5} \frac{1}{2}^{\prime \prime}$

William O. Sweet collection

111. Pipe tomahawk with pewter inlaid haft, mid-r 8 th century. Note the short thick bowl sloping inward towards the top, the large eye, and the generally massive utilitarian head, all characteristic of the early form. This is a simple specimen with few moldings and uncomplicated inlays, but it is an excellent unrestored example of its type. The haft is maple. Provenience unknown.

$\mathrm{H}: 8^{\prime \prime} \mathrm{W}: 2 \frac{1^{\prime \prime}}{}{ }^{\prime \prime} \mathrm{L}: 16^{\prime \prime}$

William W. Shemerluk collection

112. Pipe tomahawk with octagonal bowl, mid-r8th century. Pipes with polygonal bowls with or without the circular base are found most frequently in Pennsylvania and Ohio. This particular specimen was recovered in Pennsylvania. It is well forged with sharply defined moldings, a round eye, and a steel edge.

$\mathrm{H}: 6^{\prime \prime} \mathrm{W}: 2 \frac{3^{\prime \prime}}{{ }^{\prime \prime}}$

George O. Bird collection

113. Pipe tomahawk, (ca. $\mathrm{r} 75^{0}-\mathrm{r} 800$ ). The bowl is slightly straighter than those of the previous period (see No. IIr), and it lacks a top molding, but otherwise little is changed. The eye is teardrop, and the blade is stamped with the broad arrow, symbol of British government ownership, on the obverse side and with the maker's name, PARKE, on the reverse. (This may possibly be William Parke who supplied axes to the Hudson's Bay Company, I770-I790.) Such tomahawks bearing government marks were used to arm the Indian allies of Great Britain during and after the Revolution and as treaty gifts. Collected from the Mohawk.

$\mathrm{H}: 8 \frac{1}{2}^{\prime \prime} \mathrm{W}: 2 \frac{7^{\prime \prime}}{8}$

$\mathrm{MAI} / \mathrm{HF}: 22 / 72 \mathrm{I} 6$

114. Pipe tomahawk with silver inlaid haft, (ca. I 750). The short inward tapering bowl and large teardrop eye are typical, and the weld on the steel edge is quite obvious. Some of the silver band and diamond inlays are missing, but those that remain bear engraved scratchwork decorations. The haft is maple and is slightly relieved between the two rear bands where the hand would grasp it. This piece is reported to have been captured at the Battle of Tippecanoe in I8I I, which would indicate a long period of service. Attributed to the Potawatomi.

$\mathrm{H}: 8^{\prime \prime} \mathrm{W}: 25^{\prime \prime}$ L: $20 \frac{3}{8}{ }^{\prime \prime}$

$\mathrm{MAI} / \mathrm{HF}: \mathrm{I}_{5} / 8000$

115. Pipe tomahawk with head of the classic form for the mid-r 8 th century. All of the normal features for which one looks in dating a piece of this period are present in their most typical shapes and proportions: the large teardrop eye, the ample bulbous bowl sloping inward toward the top with an edge molding, the concave molding at the base of the blade, the small projection from the rear of the blade just below the base, and the heavy functional blade itself with its steel edge. The haft only is atypical, for it is exceptionally plain without any taper for a mouthpiece-possibly a separate tubular mouthpiece may have been used. This haft may not be the original, but it is certainly very old. It was collected in Indiana and has been attributed to the Miami.

$\mathrm{H}: 8 \frac{3}{8}^{\prime \prime} \mathrm{W}: 2 \frac{3}{4}^{\prime \prime} \mathrm{L}: \mathrm{I} 7 \frac{1}{8}^{\prime \prime}$

MAI/HF : IO/288I 
116. Crudely made pipe tomahawk of the late I8th or early I9th century. The eye is teardrop. The moldings are of the most rudimentary, and the bowl has been made separately and riveted in place. It was obtained from the Mohawk.

$\mathrm{H}: 8 \frac{3}{4}^{\prime \prime} \mathrm{W}: 3 \frac{11}{4}^{\prime \prime}$

MAI/HF : I $/ 2575$

117. Pipe tomahawk with a shortened and considerably reworked blade, (ca. I750-I800). The eye is teardrop, and there are file nicks along the front of the blade from just below the base molding to the reworked area. The alteration of the blade probably took place after the original steel edge had been worn away or otherwise lost; there is no trace of it left. Collected from the Sauk and Fox tribe in Illinois.

$\mathrm{H}: 7 \frac{1}{2}^{\prime \prime} \mathrm{W}: 3 \frac{3^{\prime \prime}}{}{ }^{\prime \prime}$

MAI/HF : I $8 / 8274$

118. Pipe tomahawk with unusual bowl, (ca. I750). The eye is teardrop, and the concave molding at the base of the blade is standard. The shape of the bowl, its thick stem with two rings, and the rounded base instead of the more usual pointed one are atypical. The blade has been shortened through much sharpening. Recovered in Illinois, from the Sauk.

$\mathrm{H}: 7^{\prime \prime} \mathrm{W}: 2 \frac{3^{\prime \prime}}{}$

MAI/HF : I $8 / 8273$

119. Pipe tomahawk of the late $\mathrm{I} 8$ th century believed to have belonged to Tecumseh. The head is massive and generally of the form associated with the second half of the I8th century. The eye is teardrop. The blade bears punched dots and engraved designs. On the obverse side is a rectangular silver inlay bearing the name Tuchunye in script. The reverse side bears a silver diamond with an engraved monogram that is now too worn to read. The haft is straight with only rudimentary shaping around the mouthpiece. A separate tubular piece must have been inserted if the pipe was to be smoked. At one time the haft was striped in red, green and black, and traces of the paint still remain. The axe is said to have been obtained by General Russell after Tecumseh's death at the Battle of the Thames in I8I3. The tradition that the piece belonged to the Shawnee chief can be traced back to within fifty years of his death. For another tomahawk believed to have belonged to Tecumseh see No. I20.

$\mathrm{H}: 7 \frac{1}{2}^{\prime \prime} \mathrm{W}: 2 \frac{5}{8}{ }^{\prime \prime} \mathrm{L}: 2 \mathrm{I}_{4}^{\frac{1}{4}}$

MAI/HF : I/II 58

120. Pipe tomahawk believed to have belonged to Tecumseh, (ca. I790I8ro). The eye is a teardrop, but the pipe bowl has become taller, almost nozzles haped. The metal around the eye is exceptionally thick, and the overall height of the head has increased with both a taller bowl and a longer blade, giving it the slightly attenuated appearance frequently encountered in axes of this type made about the turn of the century. The obverse side of the blade is engraved in script letters in three vertical lines To Chief Tecumseh / From Col. Proctor / MDCCCXII. (Henry Proctor was commander of the British forces with whom Tecumseh's Shawnees served in the old Northwest during the War of I8I2.) The reverse side of the blade bears a maker's stamp in the form of a standing bird with the letters B and $\mathrm{E}$ on either side plus a sun with a human face, a crescent moon with a face, and a cluster of 7 stars in a circle with one in the center. The same marks have been found on two almost identical tomahawk heads in private collections. The sun, moon, and star markings are typical of those found on Europeanmade sword blades of the I8th and early I9th centuries, and these plus the maker's mark would seem to indicate Continental, probably French, manu- 
facture. The haft is burned in stripes for decoration, and there are two protuberances on the lower edge, each pierced with a single hole-from which thongs with beads, feathers, scalps, or other decorations were undoubtedly suspended.

$\mathrm{H}: 9^{1{ }^{\prime \prime}} \mathrm{W}: 3^{\frac{11}{4}} \mathrm{~L}: 26 \frac{14^{\prime \prime}}{4}$

MAI/HF : I $7 / 6249$

121. Pipe tomahawk of the second half of the I8th century. It is a finely made specimen with crisp moldings and a well-developed bowl on a tall stem. The eye is teardrop. The haft is curly maple with a silver mouthpiece, bands, and fore-end cap. This cap bears the initials GG in script. The lower edge of the haft has been relieved between the bands, perhaps to afford a better grip for the hand. Attributed to the Iroquois.

$\mathrm{H}: 8^{\prime \prime} \mathrm{W}: 3^{\prime \prime} \mathrm{L}: \mathrm{I} 8 \frac{1}{2}^{\prime \prime}$

MAI/HF : I5/I59

122. A fine pipe tomahawk of the late $\mathrm{I} 8$ th century. The head is lighter than the earlier specimens and is slightly more sophisticated in the style usually associated with the years from 1770 to 1800 . The eye is teardrop; the moldings are less massive. There are filed decorations consisting primarily of diagonal lines and follow lines. A silver crescent is inlaid in the blade and a heart is at the base of the bowl. The fore end of the haft is covered with a cap of silver, and there is a band of silver just behind the head. Both of these are soldered to the head, making a tight joint and eliminating the need for the usual thin leather shim. The haft is curly maple and bears further silver inlays consisting of bands and diamonds bearing engraved scratchwork designs. There is also a silver mouthpiece. Provenience unknown.

$\mathrm{H}: 8 \frac{3^{\prime \prime}}{8} \mathrm{~W}: 2 \frac{3^{\prime \prime}}{4} \mathrm{~L}: 2 \mathrm{I} \frac{3^{\prime \prime}}{}{ }^{\prime \prime}$

William Guthman collection

123. Pipe tomahawk, (ca. I790-I810). This specimen illustrates the attenuated appearance of the turn-of-the-century iron pipe tomahawk head even more emphatically than No. I 20. The pipe bowl is poorly proportioned and crudely fashioned. The molding at the base of the blade is rudimentary, and the eye, though still teardrop, is a slender one. The edges of the iron around the eye and down the front of the blade have been filed to make a cusped border, and a silver knife has been inlaid in the blade. Upon this knife is engraved the name " $H$. Knox" in script. The haft is maple with one silver band and five circular silver inlays, all with light scratchwork and floral engraving. The mouthpiece, which undoubtedly was silver also, is now missing. From West Virginia.

$\mathrm{H}: 8 \frac{3}{4}^{\prime \prime} \mathrm{W}: 2 \frac{3^{\prime \prime}}{4} \mathrm{~L}: 19^{\prime \prime}$

Smithsonian Institution USNM: 13515

124. Pipe tomahawk with engraved eagle and shield on the blade, (ca. I786-I 8Io). In proportion the head of this tomahawk more closely resembles those of the mid-I 8th century. The pipe bowl is more barrel shaped, however, and it is riveted to the head instead of being welded, keyed or made in one pieceas was more common. The head proper is thick and flat, topped with well-developed step moldings. The raised central molding on the bowl has a continuous row of stamped circles for decoration. The principal decorative device, however, is an engraved American eagle with shield clutching both arrows and an olive branch in its claws. In place of the stars in the shield, however, there is the word "TOTE." There is considerable speculation concerning the meaning of this word since it appears on several 
tomahawks over a period of a hundred years. (See No. 203 for a very late example.) It has been thought to derive from the Pennsylvania German dialect as a corruption of the German Todt meaning death, but this is pure hypothesis. The haft was inlaid with a number of bands, strips, and discs of silver held by tacks, but most of these have since disappeared. The few that remain bear traces of simple scratch engraving. A screw in the fore end helps spread the haft and hold the head securely in place. The mouthpiece is pewter, held in place with an interesting semi-dovetailed effect. The haft also was lightly branded with a file, but most of this has now worn off. The provenience is not known.

$\mathrm{H}: 8^{\prime \prime} \mathrm{W}: 2 \frac{3^{\prime \prime}}{4} \mathrm{~L}: 2 \mathrm{I} \frac{3^{\prime \prime}}{}$

Robert Abels collection

125. Pipe tomahawk, also probably of British manufacture, (ca. I80o). Similar in most respects to No. I26 except that it is unmarked and the fact that the pipe bowl was riveted and welded to the poll can be clearly seen. Also, the eye is round. Attributed to the Teton Sioux.

$\mathrm{H}: 9 \frac{1{ }^{\prime \prime}}{} \mathrm{W}^{\prime}: 3 \frac{1}{4}^{\prime \prime} \mathrm{L}: 2 \mathrm{I}^{\frac{3}{4}}{ }^{\prime \prime}$

$\mathrm{MAI} / \mathrm{HF}: \mathrm{I} 8 / 277 \mathrm{I}$

126. Pipe tomahawk by Holtzappfel, (ca. I8oo). The form of the head is typically attenuated. The eye is teardrop, and the pipe bowl is straight sided though there is a slight inward taper. On the obverse side is stamped the British broad arrow and the letters BO (Board of Ordnance). On the reverse side the maker's name, "HOLTZAPPFEL," is stamped in incised capital letters. The mouthpiece is turned and shaped but is an integral part of the haft. Attributed to the Sisseton Sioux.

$\mathrm{H}: 9 \frac{1}{4}^{\prime \prime} \mathrm{W}: 3^{\prime \prime} \mathrm{L}: 22^{\prime \prime}$

MAI/HF : 2/2106

127. Pipe tomahawk, probably English, (ca. 1800 ). Similar in all important respects to the preceding two specimens, with a teardrop eye. The maker's name, "B. WOOD," is stamped in incised capital letters on the reverse side of the blade. The mouthpiece is turned from bone. Collected from the Assiniboine.

$\mathrm{H}: 8 \frac{1}{2}^{\prime \prime} \mathrm{W}: 3^{\prime \prime} \mathrm{L}: 22 \frac{1}{8}^{\prime \prime}$

$\mathrm{MAI} / \mathrm{HF}: 3 / 47 \mathrm{I} 6$

128. Pipe tomahawk, probably English, (ca. I80o). Similar to the preceding three specimens in all important respects, though the pipe bowl is narrower and more poorly formed. The eye is teardrop. The maker's name is stamped on the reverse side of the blade, " $J$ \& C THOMAS." Beneath it is another word now illegible except for the letters "AZAR," approximately in the middle. Attributed to the Plains Cree.

$\mathrm{H}: 8 \frac{1}{2}^{\prime \prime} \mathrm{W}: 3^{\prime \prime} \mathrm{L}: 2 \mathrm{I}_{4}^{1 \prime \prime}$

$\mathrm{MAI} / \mathrm{HF}: \mathrm{I} 9 / 5704$

129. Pipe tomahawk said to have been presented to Chief Warrior at the Big Tree Treaty of 1797 . The eye is oval. The pipe bowl is slightly barrel shaped and faceted with turned moldings at top and bottom. Just below the base of the bowl is inlaid a silver diamond on the reverse side, and on the blade is a silver cartouche bearing the name "Chief-Warrior" engraved in script. Two brass strips following the borders of the blade are inlaid from the base to points opposite the ends of the cartouche. The haft is striped maple with two narrow pewter bands and one wide one at the butt. The mouthpiece is a tube of bone. Warrior is a well-known Iroquois family name.

$\mathrm{H}: 81^{\prime \prime} \mathrm{W}: 3 \frac{5{ }^{\prime \prime}}{} \mathrm{L}: \mathrm{r} 7^{\prime \prime}$

$\mathrm{MAI} / \mathrm{HF}: \mathrm{IO} / 405 \mathrm{I}$ 
130. Pipe tomahawk ( $c a$. I800-I825), believed to have belonged to the famous Chief Red Cloud (1822-I909) of the Oglala Sioux. The eye is oval. The bowl is very slightly barrel shaped with moldings at top and bottom. A silver heart is inlaid in the base of the bowl, a crescent at the base of the blade, and a bleeding heart in the center of the blade. The haft is maple, inlaid with silver bands and diamonds. The mouthpiece is a silver tube.

$\mathrm{H}: 8 \frac{14^{\prime \prime}}{} \mathrm{W}: 3^{\prime \prime} \mathrm{L}: 16^{\prime \prime}$

$\mathrm{MAI} / \mathrm{HF}: 22 / 7203$

131. Pipe tomahawk made by a Chickasaw blacksmith about I8oo. (See p. 29.) The eye is oval. The bowl is of the so-called acorn shape which developed about $\mathbf{I} 77 \mathrm{O}$ and remained popular for brass specimens until about I825. There was an oval inlay, now missing, on the reverse side of the blade. There are traces of both black and red paint on the head and on the foreend of the haft. The haft bears an oval pewter inlay on the obverse side in a carved frame. The script initials EF are carved in a scrolled border on the reverse, and the butt is carved in a rudimentary scroll.

$\mathrm{H}: 7 \frac{5}{8}^{\prime \prime} \mathrm{W}: 2 \frac{7}{8}^{\prime \prime} \mathrm{L}: \mathrm{I} 8^{\prime \prime}$

MAI/HF : 73I9

132. Pipe tomahawk with silver inlays and exceptionally heavy blade, (ca. I800-I820). The bowl is straight sided and almost stemless. It has filed moldings at top and bottom and a silver inlaid band around the center. On the base of the bowl is inlaid a silver heart, while a silver crescent, "bleeding heart," and designs resembling bird footprints adorn the blade. The eye is oval, and the squared section below it is exceptionally heavy and decorated with filed moldings. The haft is apparently much more recent and is cut down to enter the eye. The mouthpiece is pewter. Obtained from the Iroquois.

$\mathrm{H}: 8 \frac{1}{4}^{\prime \prime} \mathrm{W}: 3^{\prime \prime} \mathrm{L}: 2 \mathrm{O}^{\frac{3}{4}}{ }^{\prime \prime}$

$\mathrm{MAI} / \mathrm{HF}: 6 / 34 \mathrm{I}$

133. English presentation pipe tomahawk given to Chief Bowles of the Cherokee, circa I80o. (See p. 33.) The vase-shaped bowl is finely forged and closely resembles the socket of a candlestick of the period. The eye is oval, and the blade flares symmetrically. On the obverse side opposite the eye is engraved "TUSTOWACKHA JO" in a vertical line. On the blade is engraved a panoply of arms featuring two British flags. On the reverse side is the name "BOWLES." The haft is cut down to enter the eye and is capped with silver after it has passed through. There is a silver band with borders two-thirds of the way to the butt, and there is a silver mouthpiece with similar borders. The mouthpiece and band are connected by the symbolic "silver chain of friendship" so often referred to in formal oratory. This is one of the few such presentation tomahawks with the chain still surviving intact.

$\mathrm{H}: 8^{\prime \prime} \mathrm{W}: 3 \frac{5}{8}{ }^{\prime \prime} \mathrm{L}: 2 \frac{1}{2}^{\prime \prime}$

$\mathrm{MAI} / \mathrm{HF}: \mathrm{I} 2 / 9426$

134. Pipe tomahawk, ( $c a$. I8Io-1830), presented to the Miami chief Meshingomesia (I78I-I879). The eye is oval. The bowl is tall and almost straight sided with a well-developed stem, indicating a date well into the Igth century. The entire head is engraved with diamonds, hearts, crescents, chevron and scroll work designs. The haft is curly maple inlaid with silver bands, diamonds, and circles. There is a silver fore-end cap and a silver mouthpiece. All mounts are engraved with formal borders and designs and are held in place by tacks. (See p. 32.)

$\mathrm{H}: 8^{\prime \prime} \mathrm{W}: 3^{\prime \prime} \mathrm{L}: 23^{\frac{3}{4}}$

$\mathrm{MAI} / \mathrm{HF}: \mathrm{I} 4 / 5983$ 
135. Pipe tomahawk, (ca. I8I5-I835). This is the type shown most often by Catlin in his paintings, through it is actually quite a rare type. It has a round eye, the whole blade curves back slightly, and the edge is on a slant. The bowl expands slightly toward the top and with its molding at the top of the stem somewhat resembles a candlestick. Both sides of the pipe base molding are inlaid with silver shields, and both sides of the blade bear silver ovals. The haft is banded with silver held in place by rows of round-headed brass tacks; the silver mouthpiece is similarly fastened. Attributed to the Shawnee.

$\mathrm{H}: 8^{\prime \prime} \mathrm{W}: 2 \frac{3^{\prime \prime}}{4} \mathrm{~L}: 19 \frac{1}{2}^{\prime \prime}$

$\mathrm{MAI} / \mathrm{HF}: 20 / 492 \mathrm{I}$

136. Pipe tomahawk, (ca. I $\left.825^{-1} 850\right)$. An earlier version of the type that became most popular from about I840 to I86o, it is well forged with an ample bowl which is now taller, and distinctly barrel shaped. The eye is oval, and there are numerous filed moldings for decoration as well as silver inlays. These inlays consist of a silver crescent on the obverse side and a horizontal band (now missing); on the reverse side there was a circle and another horizontal band, both of which are now lacking. The wooden haft is plain and generally of the early type. There is a lead mouthpiece and a fore-end cap also of lead. Just behind the head is another lead band with a serrated rear edge. Attributed to the Shawnee.

$\mathrm{H}: 6 \frac{1^{\prime \prime}}{1 \prime} \mathrm{W}: 2 \frac{1}{8}{ }^{\prime \prime} \mathrm{L}: \mathrm{I}^{\frac{1}{2}}{ }^{\prime \prime}$

MAI/HF : $2 / 484$

137. Pipe tomahawk, (ca. I830-1850). Another Shawnee specimen of a form of tomahawk popular during the second quarter of the I9th century, but showing some later features than No. I36. The bowl is a little taller and has almost achieved the shape that became standard shortly after I850. The edge is straighter, and although the rear line of the blade is still slightly concave, it gives evidence of the approaching straight side so typical of axes of the second half of the century. The eye is also a pointed ellipse, approaching the diamond shape found in the later specimens. The haft is quite recent, and the gasket between the haft and the inside of the eye is of cloth, a very late feature. The haft is finished an unnaturally light color and is inlaid with silver diamonds and triangles.

$\mathrm{H}: 7^{\frac{1}{2}}{ }^{\prime \prime} \mathrm{W}: 2 \frac{1}{2}^{\prime \prime} \mathrm{L}: \mathrm{I}^{\frac{3}{4}}{ }^{\prime \prime}$

$\mathrm{MAI} / \mathrm{HF}: 2 / 48 \mathrm{I} 2$

138. Very fine example of a pipe tomahawk, probably made in the first quarter of the I9th century. The bowl is quite tall in proportion to its diameter, but it tapers inward slightly toward the top. The eye is a teardrop, and the molding beneath the eye is well developed. On the obverse side there is a silver crescent inlay, and on the reverse is a silver oval. The haft is of the early form, inlaid with silver diamonds and bands decorated with scratchwork engraving. The mouthpiece is silver, and an unusual feature is a spiral brass band which runs the entire length of the haft. Collected from the Mandan.

$\mathrm{H}: 6 \frac{1^{\prime \prime}}{}{ }^{\prime \prime} \mathrm{W}: 2 \frac{1}{8}^{\prime \prime} \mathrm{L}: \mathrm{I} 6 \frac{3}{4}^{\prime \prime}$

MAI/HF : I9/639

139. Pipe tomahawk dated I829. There are many early features on this well-forged specimen. The eye is teardrop, and the bowl, although tall, retains early moldings at its base. The moldings below the eye also reflect the taste of the late I 8th or early I 9 th century. The obverse of the blade is decorated with brass inlays including a bird, the letters OC, the date I829, 
and foliage. On the reverse side the inlays consist of a tree and scrollwork; the edge is steel. Attributed to the Sauk and Fox.

$\mathrm{H}: 6_{4}^{3 \prime \prime} \mathrm{W}: 3^{\prime \prime}$

$\mathrm{MAI} / \mathrm{HF}: \mathrm{I} 8 / 8272$

140 and 141. Pipe tomahawks which belonged to the Sauk chief Keokuk, (I 780-1848). Both were given to Indian Agent Woodyard by Moses Keokuk who stated that they had belonged to his father. No. I40 must have been given to Keokuk late in life after the crises of the Black Hawk War when he fell from favor with his people. The blade is almost the fully developed form of the second half of the century, although there are a few earlier features, especially the heaviness of the metal around the eye. The pipe also is a slightly earlier form with its bulbous moldings. The eye is oval. There are inlaid triangles on either side of the bowl base molding, two horizontal bars on either side of the eye, and a diamond in the center of the blade, all of silver. Further decoration of this fine quality head is provided with stamped crosses and crescents. The haft has a silver front cap which has been covered with lead, and a lead band is at the rear of the head, making a tight seal. In addition, there are a series of silver bands and diamonds. There is no mouthpiece except for the shaping of the wood.

No. I4I is also an especially fine piece and slightly earlier; it could well have belonged to Keokuk at the time of the Black Hawk War. The eye is a teardrop. The bowl is short and of large diameter, and the blade form is early. There is a brass or copper front plate covered with lead which, together with a lead band just behind the head, forms a tight seal. The haft tapers at the rear in the earlier form as contrasted with the later concave taper exhibited in No. I 40. There is a pewter mouthpiece with a serrated edge adjoining the haft, and several silver bands and a silver heart are inlaid along the sides of the haft.

No. I 40. H: $7 \frac{1}{4}^{\prime \prime} \mathrm{W}: 2 \frac{1 \frac{1}{2}^{\prime \prime}}{\mathrm{L}}: 14 \frac{7}{8}^{\prime \prime}$

$\mathrm{MAI} / \mathrm{HF}: \mathrm{I} 2 / 744$

No. I 4 I. H: $6 \frac{3}{4}^{\prime \prime} \mathrm{W}: 2 \frac{1{ }^{\prime \prime}}{8}$ L: $15 \frac{7^{\prime \prime}}{8}$

$\mathrm{MAI} / \mathrm{HF}: \mathrm{I} 2 / 745$

142. A most unusual pipe tomahawk with bilaterally flaring blade, ( $c a$. $\mathrm{I} 840-\mathrm{I} 850$ ). The eye is round. The bowl is tall and is welded to the flat poll. On either side of the eye are filed moldings in a reeding pattern. The blade is even more remarkable by having two convex brass bosses soldered on either side and by the fact that three circular holes are bored through just above the edge. The haft is grooved along its lower edge and is wrapped with copper wire. It was found in Ohio and acquired by the Smithsonian in $\mathrm{x} 868$.

$\mathrm{H}: 8 \frac{1}{4}^{\prime \prime} \mathrm{W}: 4 \frac{7}{8}^{\prime \prime} \mathrm{L}: \mathrm{I} 7 \frac{1}{4}^{\prime \prime}$

Smithsonian Institution

USNM: 7339

143. Pipe tomahawk, (ca. I 835-1850). The blade, forged of iron with a steel edge, has here assumed the shape most characteristic of the 1840 's and early I850's with a notch just below the eye forming a narrow waist above a pronounced rearward flare to the heel. The bowl is tall with several moldings and tapers slightly inward towards the top. The entire head is decorated with an overall pattern of punched dots. The eye is oval. The haft is inlaid with pewter bands, and there is a pewter mouthpiece. Attributed to the Iroquois, New York.

$\mathrm{H}: 7 \frac{1}{2}^{\prime \prime} \mathrm{W}: 2 \frac{1}{2}^{\prime \prime} \mathrm{L}:$ I9 $\frac{3^{\prime \prime}}{}$

MAI/HF : I $4 / 4873$ 
144. Pipe tomahawk by Carlos Gove, (ca. I840-1854). A well-made axe that would seem to have been made during Gove's tenure at the Potawatomi Agency or at St. Joseph. The eye is oval, and the notch below the eye is not so pronounced as in some specimens. The bowl is tall and slightly barrel shaped with well-executed moldings. The workmanship throughout is excellent, especially the filing of the moldings on either side of the eye. The obverse of the blade bears a large stamp of concentric cabled rings with some wavy lines between the rings. In the center are four eagle heads and the name C. GOVE. The reverse side is engraved with a walking bird and several tree stumps. The haft is inlaid with pewter bands and diamonds, and the mouthpiece is pewter. Attributed to the Potawatomi(?). For another pipe tomahawk by Gove, see No. 147 .

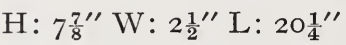

$\mathrm{MAI} / \mathrm{HF}: 22 / 7220$

145. Pipe tomahawk, (ca. I840-I850). In this specimen the notch below the eye is not nearly as sharp as in some, but the narrow waist is quite apparent. The eye is oval. The tall bowl is faceted with cabled moldings at top and bottom and a slight outward flare toward the top. There is a series of brass inlays in the form of bars across the blade between the eye and the waist, and there are triangular inlays, a diamond, and a star around the sides of the eye. The haft is inlaid with pewter bands and rectangles, and there is a pewter cap. The mouthpiece is lead. Collected in Oklahoma from the Caddo.

$\mathrm{H}: 6 \frac{7^{\prime \prime}}{8} \mathrm{~W}: 2^{\prime \prime} \mathrm{L}: 14 \frac{3}{8}{ }^{\prime \prime}$

MAI/HF : $2 / 2398$

146. Pipe tomahawk, (ca. 1825-1840). The shorter, thicker form of this specimen is readily apparent when compared with the three previous ones. It is forged of iron with a steel edge, and the eye is round. The bowl is short and thick with cabled moldings top and bottom. The haft is inlaid with pewter bands and diamonds, and there is a pewter mouthpiece. Collected from the Creek tribe in Oklahoma.

$\mathrm{H}: 6 \frac{1}{4}^{\prime \prime} \mathrm{W}: 2 \frac{1}{8}^{\prime \prime} \mathrm{L}: 13 \frac{1}{4}^{\prime \prime}$

$\mathrm{MAI} / \mathrm{HF}: 2 / 7567$

147. Pipe tomahawk by Carlos Gove, (ca. $\left.1845^{-1} 854\right)$. This axe also probably dates from Gove's years in St. Joseph, but it is later in its design than No. I44. It was collected among the Potawatomi with whom Gove had been associated as Agency gunsmith. In this specimen the eye has assumed the diamond form typical of the I850's and later. The blade also is assuming the flat straight-sided form which became more pronounced in the next decade. The bowl is tall and barrel shaped with simple moldings at top and bottom, but it is slightly thicker than the later examples. There is a brass band inlaid around the pipe bowl, and a silver disc is inlaid on the obverse of the blade. This disc is stamped with a series of short arcs and small circles which form a conventionalized flower and border. Around the silver disc is engraved a larger double circle, and conventional flowers are stamped in the space between. The name C. GOVE is stamped above a longer word, now illegible. The haft is covered with punch marks, and there is a pewter cap and mouthpiece. See also No. I44.

$\mathrm{H}: 6 \frac{7}{8}{ }^{\prime \prime} \mathrm{W}: 2 \frac{1}{2}{ }^{\prime \prime} \mathrm{L}: \mathrm{I} 8 \frac{3^{\prime \prime}}{}$

MAI/HF : $2 / 7569$

148. Pipe tomahawk with widely flaring blade, (ca. I835-1850). The unusual rear line of the blade almost obscures the thin waist and other characteristics of the axes of the I840's, but nevertheless this specimen 
belongs to that period. The eye is round, and the bowl is short and thick, both early features which might indicate a date in the opening years of the period. The blade is highly decorated with both stamping and silver inlays. Only traces of the stamping remain, but it comprised floral sprays. The inlays consist of a band around the bowl, triangles, lines, and a crescent on the obverse side and a diamond, lines, and triangles on the reverse. The haft is tiger striped, but otherwise undecorated. From the Iroquois; collected in New York.

$\mathrm{H}: 6 \frac{1}{8}^{\prime \prime} \mathrm{W}: 2 \frac{1}{2}^{\prime \prime} \mathrm{L}: \mathrm{II}^{\frac{3}{4}}{ }^{\prime \prime}$

MAI/HF : $22 / 4005$

149. Pipe tomahawk, (ca. I840-1850). Compared with the large eye and bowl, the small blade of this axe seems quite out of proportion. The eye is oval; the bowl tall and flaring out towards the top. There is a cabled molding at the neck, but none at the top. Above the narrow waist the corners of the blade are filed in a series of notches. Below the waist are copper inlays consisting of a series of three lines and a heart. The haft is inlaid with silver bands and rectangles. The mouthpiece and cap are pewter or lead. Attributed to the Caddo in Oklahoma.

$\mathrm{H}: 7^{\prime \prime} \mathrm{W}: 2^{\prime \prime} \mathrm{L}: \mathrm{I} 6 \frac{\frac{1}{2}^{\prime \prime}}{}$

MAI/HF : $2 / 2397$

150. Pipe tomahawk, (ca. I830-1850). A finely made specimen with an oval eye and well-developed moldings on the bowl and at the base of the blade. The bowl itself is quite short, but it is situated upon a long neck and a high poll. In addition to the moldings, the decoration consists of stamped crescents along the borders of the blade, a cartouche and a heart inlaid in brass on the obverse, and a silver cartouche and diamond with a copper circle in its center on the reverse. The haft is decorated with silver bands, a pewter cap, and a pewter mouthpiece. Attributed to the Caddo in Oklahoma. $\mathrm{H}: 6^{\prime \prime} \mathrm{W}: 2 \frac{1{ }^{\prime \prime}}{} \mathrm{L}: \mathrm{I} 3^{\frac{3}{4}}{ }^{\prime \prime}$

MAI/HF : I2/866

151. Pipe tomahawk, (ca. I840-1855). In this specimen, which was obtained from a Cherokee man, the features of the I840's are giving way to those of the I 850 's. The narrow waist of the blade has moved up just below the eye. The eye itself is diamond shaped, and there is a slight forward flare to the front line of the blade. The bowl is barrel shaped, but not so tall and slender as in later forms. There are well-developed moldings on the lower portion of the eye, and there are punched decorations of conventionalized flowers and floral sprays made up of many individual short straight lines. The haft has a pewter cap but is otherwise plain, except for notches carved in the narrowed mouthpiece.

$\mathrm{H}: 7 \frac{1{ }^{\prime \prime}}{}{ }^{\prime \prime} \mathrm{W}: 2 \frac{3^{\prime \prime}}{4} \mathrm{~L}: \mathrm{I} 8 \frac{1{ }^{\prime \prime}}{}$

$\mathrm{MAI} / \mathrm{HF}: 20 / 4929$

152. Pipe tomahawk, (ca. I830-I850). Forged of very soft iron, this specimen presents both an unusual bowl and haft. The bowl is tall with a groove around its center and a cabled molding at its base. The eye is a pointed ellipse, almost diamond shaped, but not quite fully developed. The filed moldings at the base of the blade are characteristic. The haft has an unusual swelling two-thirds of the way towards the free end and then tapers more sharply to the lead mouthpiece. There is also a lead fore-end cap. Like No. I86, it was collected from the Mexican Kickapoo, and was said to have been brought with them when they fled Texas in $\mathbf{1} 852$.

$\mathrm{H}: 6 \frac{1}{2}^{\prime \prime} \mathrm{W}: 2^{\prime \prime} \mathrm{L}: \mathrm{I} 5^{\prime \prime}$

MAI/HF : $2 / 4539$ 
153. Pipe tomahawk by Horace Dimick, (ca. I849-I860). The axe is of the style normally associated with the I840's with a thin waist well below the bottom of the eye. Dimick did not move to St. Louis until I 849 , however, so that a tomahawk bearing that address could not have been made earlier. It is a handsome specimen worthy of the fine workmanship found also in his target rifles. The bowl is relatively wide in proportion to its height and flares slightly towards the top. There are moldings at both top and bottom. The eye itself is oval, but the outer surfaces have been filed to give an indication of the diamond shape soon to become almost universal. Silver inlays in straight lines and geometrical patterns decorate the blade, and there are also punched crescents. On the reverse also is a two-line stamping “H. E. DIMICK / ST. LOUIS." The haft is absolutely plain except for one brass tack on the obverse side, just behind the head. Attributed to the Nez Percé.

$\mathrm{H}: 7 \frac{1}{2}^{\prime \prime} \mathrm{W}: 2 \frac{1}{4}^{\prime \prime} \mathrm{L}: \mathrm{I}^{\prime \prime}$

$\mathrm{MAI} / \mathrm{HF}: 20 / 4924$

154. Pipe tomahawk with exceptionally long and heavily carved haft, (ca. I830-I 850). The eye is teardrop in the earlier form. The tall simple bowl is almost barrel shaped, but with a molding only at the top and no neck. It is threaded and screws into the poll. There are no moldings of any kind. By contrast with the plain head, the haft is elaborately carved in a series of scrolls along the top, bottom, and sides as the haft itself changes from a vertical diamond at the head to a flattened diamond at the mouthpiece. The general effect is heightened by the use of red and green paint. From the Ottawa.

$\mathrm{H}: 6^{\prime \prime} \mathrm{W}: 2 \frac{1}{8}^{\prime \prime} \mathrm{L}: 20 \frac{3}{4}^{\prime \prime}$

$\mathrm{MAI} / \mathrm{HF}: \mathrm{I} 5 / 6256$

155. Pipe tomahawk, (ca. I840-1860). This very simple specimen reflects several early aspects, but the design of the bowl and the workmanship indicate a date in the second quarter of the century rather than in the first, as might be assumed at first glance. The eye is teardrop and ample in size with a simple molding below. The bowl is tall and generally urn shaped. It has been carefully filed in a series of diamond-shaped facets just below the top molding and six flat facets below these. The rest of the head is starkly simple in contrast. The haft is recent, with a cloth gasket inside the eye. Collected from the Shawnee.

$\mathrm{H}: 6 \frac{5}{8}^{\prime \prime} \mathrm{W}: 2 \frac{1}{4}^{\prime \prime} \mathrm{L}: \mathrm{I} 6^{\prime \prime}$

$\mathrm{MAI} / \mathrm{HF}: \mathbf{I O} / 2889$

156. Pipe tomahawk, (ca. I850-1870). A crudely formed specimen forged in one piece from a tube. The eye is a teardrop but small. There is almost no delineation of the neck and only a suggestion of moldings on the bowl. The haft is plain except for a shaped mouthpiece. Attributed to the Winnebago.

$\mathrm{H}: 5^{\prime \prime} \mathrm{W}: 2 \frac{3}{4}^{\prime \prime} \mathrm{L}: \mathrm{I}^{\prime \prime}$

$\mathrm{MAI} / \mathrm{HF}: 2 \mathrm{I} / 5 \mathrm{O} 4 \mathrm{I}$

157. Simple pipe tomahawk, (ca. I840-1860). The workmanship and overall design bear a strong resemblance to No. I55, and indeed the basic forgings may have been identical, the surface differences being produced by the finish filing. The general shape, including the ample teardrop eye and simple molding at the base of the blade, strongly indicates manufacture by the same hand. Even the outer dimensions are identical to within oneeighth of an inch in height. In this instance the bowl is filed into an octagonal form without the more complicated diamond facets, but then the eye 
area has been faceted instead. The haft is simple and straight with a horn mouthpiece. Attributed to the Wyandot.

$\mathrm{H}: 6 \frac{3}{4} " \mathrm{WV}: 2 \frac{1^{\prime \prime}}{4} \mathrm{~L}: 155^{\prime \prime}$

$\mathrm{MAI} / \mathrm{HF}: \mathbf{I} / 9565$

158. Simple pipe tomahawk, (ca. I840-I860). Another specimen apparently by the same hand. This time the base of the bowl is not as well finished, and the top of the blade has been filed away at the rear to produce more of a flare. All basic elements are the same, however, and the dimensions are almost identical. The haft in this instance is considerably more ornate, with a series of brass bands and a pewter mouthpiece. Attributed to the Cherokee. $\mathrm{H}: 7^{\prime \prime} \mathrm{W}: 2 \frac{1{ }^{\prime \prime}}{4} \mathrm{~L}: 16 \frac{1}{4}^{\prime \prime}$

MAI/HF : I/9864

159. Pipe tomahawk, (ca. I830-I850). A very well-forged head with the steel edge clearly discernible, even in the photograph. The eye is teardrop. The bowl is a bit ponderous, but well finished with straight sides and octagonal bands top and bottom. The double molding at the base of the neck where it joins the poll is particularly well done. Aside from the moldings, the only other decoration consists of a series of stamped ovals which form a border around the eye area. The haft is plain with a pewter mouthpiece. From the Seneca in Oklahoma.

$\mathrm{H}: 6 \frac{5}{8}{ }^{\prime \prime} \mathrm{W}: 2 \frac{1}{2}^{\prime \prime} \mathrm{L}: 15 \frac{3}{8}^{\prime \prime}$

$\mathrm{MAI} / \mathrm{HF}: \mathrm{IO} / 2882$

160. Elaborate pipe tomahawk, (ca. I840-I860). The basic form with narrow-waisted blade, oval eye and tall thick bowl has been decorated with an inlaid silver heart and bars of silver and copper, as well as with punched circles. The haft has been inlaid with silver bands and rectangles, and there is a pewter mouthpiece and cap. There are also traces of file branding. The early shape of the haft and the type of decoration would tend to indicate a date within the early part of the general period given above. Collected from a Caddo woman in Oklahoma.

$\mathrm{H}: 7^{\prime \prime} \mathrm{W}: 2 \frac{1{ }^{\prime \prime}}{\mathrm{L}} \mathrm{L}: \mathrm{I}_{5} \frac{1}{4}^{\prime \prime}$

$\mathrm{MAI} / \mathrm{HF}: 2 / 2396$

161. Pipe tomahawk with a head of the I840-I860 type and late I9th century haft. The head is a simple forging of the narrow-waisted type with an oval eye and a tall thick bowl. The haft, however, is rectangular in section and is so heavily decorated it could be used only for display; it is not even pierced for smoking. It is studded with brass tacks. A feather is attached to a tack in the fore end, and a socket of buckskin with an attached beaded flap covers the other. The flap is 34 inches long, is beaded, and terminates in a long section of red cloth. Further decoration is provided with ermine fur, fringe, and hawk bells. Attributed to the Shoshoni. See frontispiece.

$\mathrm{H}: 8^{\prime \prime} \mathrm{W}: 2 \frac{1}{2}^{\prime \prime} \mathrm{L}: 24 \frac{1}{2}^{\prime \prime}$

$\mathrm{MAI} / \mathrm{HF}: 2 / 3330$

162. Pipe tomahawk by Joseph Jourdain. A finely forged hatchet made towards the end of his career, circa I845-I855. The eye is a pointed ellipse, not quite a diamond. The tall bowl tapers inward towards the top where there is an incised follow line but no molding. On the blade are a series of circular touches with raised crosses in them reminiscent of those found on the simple trade hatchets of the late 17 th and early I8th centuries. In addition, there are brass inlays of conventionalized floral sprays radiating from a common center plus two bands around the bowl. The haft is completely plain. Collected from the Mahikan.

$\mathrm{H}: 7 \frac{1^{\prime \prime}}{} \mathrm{W}: 3^{\prime \prime} \mathrm{L}: 26^{\prime \prime}$

$\mathrm{MAI} / \mathrm{HF}: \mathrm{I} / 2 \mathrm{I} 3 \mathrm{I}$ 
163. Pipe tomahawk, (ca. I849). This specimen is of the same general style of the Jourdain tomahawk mentioned above, but much more crudely made. The eye is a pointed ellipse. The bowl is tall with a slight inward taper at the top and no upper molding. Most interesting is the fact that a United States penny, dated 1849 , is inlaid on the reverse side of the blade, thus helping to fix its date. The haft is wrapped with brass wire over which are two bands of red cloth with black-and-white beadwork. Attributed to the Sauk and Fox.

$\mathrm{H}: 7 \frac{3}{8}^{\prime \prime} \mathrm{W}: 2 \frac{1}{2}^{\prime \prime} \mathrm{L}: 19 \frac{3}{4}^{\prime \prime}$

MAI/HF : $16 / 4766$

164. Pipe tomahawk, second half of the I9th century. This specimen is difficult to date precisely. The bowl is of a type normally associated with the period I840-1860, but the narrowness of the band around the eye, the shape of the blade and the workmanship, would seem to indicate a date considerably later than that. The eye is round. The decoration consists of cabled moldings at the top and bottom of the bowl and incised lines as its base and around the eye area. The haft is carved into four segments separated by double ring moldings. The rear three of these segments have four flat faces, each of which bears two pointed ellipses of pewter nailed in place and stamped $X X X$. There is a pewter mouthpiece and an end cap. Attributed to the Potawatomi.

$\mathrm{H}: 7 \frac{1}{8}^{\prime \prime} \mathrm{W}: 2 \frac{1}{8}^{\prime \prime} \mathrm{L}: \mathrm{I} 7 \frac{3}{8}^{\prime \prime}$

$\mathrm{MAI} / \mathrm{HF}: \mathrm{I} 6 / 9268$

165. Pipe tomahawk, second half of the I9th century. Like the previous specimen, this is also difficult to date precisely; it varies so much from any common pattern that there are no readily recognizable and datable features. The long neck and tall bowl would place it no earlier than mid-century, however. The blade is very narrow, and the eye is round. The shaft is short and plain except for a pewter mouthpiece and a pewter end cap which has chevrons engraved upon it. From the Fox tribe in Iowa.

$\mathrm{H}: 6 \frac{1}{8}^{\prime \prime} \mathrm{W}: \mathrm{I}_{4}{ }^{\prime \prime} \mathrm{L}: \mathrm{x} 2 \frac{3}{4}^{\prime \prime}$

$\mathrm{MAI} / \mathrm{HF}: 2 / 7865$

166. Pipe tomahawk, mid-rgth century. The tall bowl with its urn shape, the oval eye, and the raised moldings stamped with crescents in the eye area are all typical of the middle decades of the last century. The blade is quite unusual but seems to be an early variant of the thin straight-sided form which became most popular in the I860's and I870's. The reverse side has a border of stamped bow and narrow designs. The haft is plain. Attributed to the Sioux.

$\mathrm{H}: 7^{\prime \prime} \mathrm{W}: 2 \frac{3^{\prime \prime}}{4} \mathrm{~L}: 19 \frac{1{ }^{\prime \prime}}{}$

$\mathrm{MAI} / \mathrm{HF}: \mathrm{I} 5 / 3382$

167. Pipe tomahawk, (ca. I850-1870). This example is identical to No. 163 except that it does not have the inlaid penny and its haft is decorated differently. In this instance the haft is studded with brass tacks along the top and in a single diagonal band. There are also traces of file branding. Suspended on rawhide thongs from a hole in the bottom are a feather with its quill wrapped in red cloth, brass and bone beads and two. 32 caliber Smith \& Wesson cartridge cases. From a Chippewa collection.

$\mathrm{H}: 7 \frac{1}{4}^{\prime \prime} \mathrm{W}: 2 \frac{1}{2}^{\prime \prime} \mathrm{L}: 18 \frac{1}{4}^{\prime \prime}$

MAI/HF : $18 / 4764$

168. Pipe tomahawk, second half of the Igth century. The general size and design of this specimen, aside from the bowl, would tend to indicate a fairly early date. The eye is teardrop. The blade is large and functional with a curving flare to the rear. The workmanship, however, is crude and not in 
keeping with an early date. Moreover, the bowl is small in proportion to the head and poorly developed. The haft is plain and appears to be more recent than the head. From the Cayuga of New York.

$\mathrm{H}: 7 \frac{5}{8}^{\prime \prime} \mathrm{W}: 2 \frac{1}{2}{ }^{\prime \prime} \mathrm{L}: 18^{\prime \prime}$

MAI/HF: $10 / 4048$

169. Pipe tomahawk, (ca. I850-1860). A factory-made specimen, this bears a partially legible name ending in "SON / PITTSBURGH, PA" in two lines. The eye is rectangular. The bowl flares outward towards the top and is completely devoid of moldings. It rests upon a flattened poll wide enough to taper to the edge in a straight line without expanding in the area of the eye. The haft is plain except for a rawhide thong which may at one time have attached a feather, bells, or other decorations. Said to have been obtained from a Canadian Mohawk Indian.

$\mathrm{H}: 6^{\prime \prime} \mathrm{W}: \mathrm{I} \frac{7^{\prime \prime}}{8} \mathrm{~L}: \mathrm{I} 2 \frac{3^{\prime \prime}}{}$

$\mathrm{MAI} / \mathrm{HF}: \mathrm{I} / 2376$

170. Pipe tomahawk, (ca. I850-1860). The blade shape of this axe is most unusual, with the two basal processes above an almost hemispherical section. The eye is oval, and the bowl is straight sided with an outward flare. It has no neck and no moldings. The haft seems more recent than the head, and is plain except for file branding. Attributed to the Nez Percé.

$\mathrm{H}: 5 \frac{1}{2}^{\prime \prime} \mathrm{W}: 3^{\prime \prime} \mathrm{L}: \mathrm{I} 7 \frac{1}{2}^{\prime \prime}$

MAI/HF: $20 / 4922$

171. Pipe tomahawk, (ca. I850-1860). This specimen, of unknown provenience, presents an interesting transition between the blade form with a straight forward line and a flare to the rear (which had been the most popular style for over a century) and the double straight-sided flare which became popular in the I860's and almost universal in the I870's. The eye is oval, and the bowl is well developed, flaring outward slightly with moldings at the top and bottom. The date I8II has been stamped on the head in recent years.

$\mathrm{H}: 6 \frac{1^{\prime \prime}}{} \mathrm{W}: 3 \frac{3}{4}^{\prime \prime}$

$\mathrm{MAI} / \mathrm{HF}: 22 / 7324$

172. Pipe tomahawk, (ca. 1850-1870). This interesting specimen is of the same general group as numbers 163 and 167 . It is distinguished, however, by moldings at the top and bottom of the bowl and by a most unusual basal process at the rear of the blade. The eye is in this instance a teardrop. The haft has been file branded and studded with brass tacks. At the end, near the mouthpiece, is tied a sunburst decoration of feathers. Attribution given only as "Plains."

$\mathrm{H}: 7 \frac{5}{8}^{\prime \prime} \mathrm{W}: 3 \frac{1{ }^{\prime \prime}}{4} \mathrm{~L}: 2 \mathrm{O}^{\prime \prime}$

$\mathrm{MAI} / \mathrm{HF}: 6980$

173. Pipe tomahawk, (ca. I850-I870). Another specimen of the same general category as the previous axe. In this instance, however, the eye is round, and the bowl is characterized by a sudden inward taper halfway between its top and bottom moldings. The plain wooden haft has been varnished, and there are two groups of serrations carved into the lower edge. It is one of the few Seminole specimens encountered in this study. $\mathrm{H}: 6 \frac{3^{\prime \prime}}{}{ }^{\prime \prime} \mathrm{W}: 38^{1 \prime \prime} \mathrm{L}: 25 \frac{12^{\prime \prime}}{}$

MAI/HF : 4/5IO5

174. Pipe tomahawk, (ca. I840-1860). Very slender in proportion to its height, this axe is dominated by its pipe bowl. This feature is tall with a well-defined neck and flares outward toward the top. It is girdled with a series of grooves and moldings, some of them cabled. Raised moldings are also found as borders around the eye area. The eye is oval. The haft is 
plain, though once it was studded with brass tacks along its upper edge. A rawhide thong is tied through a hole immediately adjacent to the mouthpiece. Attributed to the Teton Sioux.

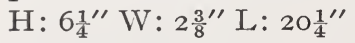

MAI/HF : I6/5I74

175. Pipe tomahawk by O. B. Sprague, (ca. I 825-1850). Probably of English manufacture, this specimen has the simple base molding and exaggerated rearward flare of the blade characteristic of the I83o's. The eye also is teardrop, but the bowl is almost of the barrel-shaped type and sits upon a long neck, which is usually a later style. The maker's name appears in a vertical line on the reverse side of the blade. The haft is studded with brass tacks, and one band of incised lines is carved around it. Collected from the Chippewa.

$\mathrm{H}: 6^{\prime \prime} \mathrm{W}: 2 \frac{7^{\prime \prime}}{8} \mathrm{~L}: 23^{\prime \prime}$

MAI/HF : $18 / 4928$

176. Pipe tomahawk with porcupine quill and feather decorations, (ca. I 850-I 870). By no means a highly finished or refined piece, this tomahawk has considerable strength and force in its forging. The eye is oval. The bowl sits atop a long neck and has moldings at top and bottom and uneven flat surfaces filed around its lower half. Most unusual are the filed moldings at the base of the blade. Instead of being horizontal and parallel, these grooves slant so that the upper ones rise part way up the eye area. The haft bears traces of red paint and is pierced with three holes. From each of these holes a group of feathers is suspended, attached to rawhide thongs around which porcupine quills, stained red, white, blue, and green, have been wrapped. Collected among the Sioux.

$\mathrm{H}: 6^{\prime \prime} \mathrm{W}: 2 \frac{3^{\prime \prime}}{8} \mathrm{~L}: 22^{\prime \prime}$

William O. Sweet collection

177. Pipe tomahawk, (ca. I875-I900). During the late I9th century, and even early in the 2oth century, a group of tall, thin pipe tomahawks was produced for ceremonial use. Usually they were crudely made, and sometimes they were cast instead of forged. In this specimen, the eye is oval. The bowl is tall and urn shaped with double moldings at top and bottom. There are a few incised X's on the sides. None of the moldings is sharply defined. The haft has a piece of buckskin tacked to the top near the head and is encircled with a pewter band. The band is stamped with floral designs. The tacks are brass. Suspended from two rawhide thongs are beads, a thimble, a brass tinkler, and fringe of red cloth and rawhide. Attributed to the Ute.

$\mathrm{H}: 8 \frac{1}{2}^{\prime \prime} \mathrm{W}: 2 \frac{1}{4}^{\prime \prime} \mathrm{L}: 2 \mathrm{O}^{\frac{3}{4}}{ }^{\prime \prime}$

$\mathrm{MAI} / \mathrm{HF}: 20 / 2922$

178. Pipe tomahawk, late I9th century. Another of the long slender type, even more crudely finished. In this specimen, attributed to the Arapaho, the edge has not been beveled and remains one-sixteenth of an inch thick. The haft which is quite recent, is decorated with a few brass tacks and grooves filled with red paint.

$\mathrm{H}: 8 \frac{1}{2}{ }^{\prime \prime} \mathrm{W}: 2 \frac{1}{8}{ }^{\prime \prime} \mathrm{L}: 5^{\frac{1}{2}}{ }^{\prime \prime}$

MAI/HF : $20 / 2926$

179. Pipe tomahawk, (ca. I $850-1870$ ). The most interesting feature of this specimen is the stamped decoration on the blade in which conventional floral patterns have been developed using sunburst, triangular, and crescentic stamps. The bowl is exceptionally tall with a slight outward flare. It is completely devoid of moldings but does have two scratchwork bands engraved upon it. The eye is a teardrop. The haft is quite recent and is studded with brass tacks; it is not pierced for smoking. From the Sioux.

$\mathrm{H}: 6 \frac{7^{\prime \prime}}{8} \mathrm{~W}: 3^{\prime \prime} \mathrm{L}: 2 \mathrm{O} \frac{{ }^{\prime \prime}}{}$

$\mathrm{MAI} / \mathrm{HF}:$ I $2 / 4429$ 
180. Pipe tomahawk, (ca. I850-1870). This Chippewa specimen may well have been made by the same hand as the previous one. There is a general similarity in the shape of the blade, and the decorations were created with the same set of stamps, although the individual punches are arranged somewhat differently. In this instance also, there is a hole drilled through the blade. The bowl on this specimen is more fully developed, with a slight barrel form and moldings at top and bottom. The eye is oval. The haft appears to be later, and is studded with brass tacks in four bands and in smaller groups. Most interesting are what appear to be cast iron fishhooks set into the wood as part of the ornamentation.

$\mathrm{H}: 6 \frac{1}{4}^{\prime \prime} \mathrm{W}: 2 \frac{3^{\prime \prime}}{4} \mathrm{~L}: 2 \mathrm{I}^{\frac{3}{4}}{ }^{\prime \prime}$

MAI/HF : I6/927I

181. Pipe tomahawk, (ca. I850-1880). Another of the long attenuated type related to numbers $\mathrm{I} 77$ and $\mathrm{I} 78$, but much better made. The eye is teardrop. The bowl is small but well developed with moldings at top and bottom, and there are ears along the haft at the eye. The haft itself is short and plain except for a bone mouthpiece. Said to have been of Iroquois ownership.

$\mathrm{H}: 6 \frac{1{ }^{\prime \prime}}{} \mathrm{W}^{\prime} 2^{\prime \prime} \mathrm{L}: \mathrm{II} \frac{3^{\prime \prime}}{}$

MAI/HF : I2/IOI

182. Pipe tomahawk, (ca. I860-1880). Another of the type with low, thick bowl. In this instance the bowl has both top and bottom moldings, the lower one cabled. The eye is oval, and the blade is plain. The haft is recent and is decorated with wrappings of copper wire and one group of brass tacks. A Blackfoot specimen, collected in Montana.

$\mathrm{H}: 6 \frac{1}{2}^{\prime \prime} \mathrm{W}: 3^{\prime \prime} \mathrm{L}: 23 \frac{1}{2}^{\prime \prime}$

$\mathrm{MAI} / \mathrm{HF}: 5 / 6792$

183. Pipe tomahawk, (ca. I860-I880). In this specimen the pipe bowl is most unusually formed with a tall, thick neck that has been faceted by filing. The eye is round, and on the outside of the straps forming the eye roughly parallel grooves have been filed for decoration. The blade itself is thin, unsharpened, and useless as a weapon. It has been pierced with a "bleeding heart." The haft has inlaid pewter bands and diamonds, mouthpiece, and fore-end cap. One section is wrapped with brass wire and a strip of fur, and twelve brass bells are suspended from a rawhide thong. Collected from the Sauk and Fox.

$\mathrm{H}: 8 \frac{3^{\prime \prime}}{8} \mathrm{~W}: 2 \frac{14^{\prime \prime}}{} \mathrm{L}: 2 \mathrm{O}^{\frac{3}{4}}{ }^{\prime \prime}$

MAI/HF : $2 / 6537$

184. Pipe tomahawk, (ca. I860-1890). A most unusual feature of this axe is the long rod welded to the rear of the blade. There is no apparent purpose for this feature, although it may have held some decorative device at one time, since it is threaded at its free end. The tall octagonal pipe bowl also is threaded and unscrews. The blade is blunt and was never beveled for an edge. It bears a triangular brass inlay near the edge. The haft is file branded for most of its length. Attributed to the Sisseton Sioux.

$\mathrm{H}: 6 \frac{1}{2}^{\prime \prime} \mathrm{W}: 2 \frac{1}{8}^{\prime \prime} \mathrm{L}: 20 \frac{1}{4}^{\prime \prime}$

MAI/HF : $3 / 6823$

185. Pipe tomahawk, (ca. I860-1880). Although the bowls of most pipe tomahawks of the second half of the Igth century were tall and slender, there was a small group in which these were short and thick. This specimen is one of the latter category. The short, thick bowl has a knurled molding at the top and none at the bottom. The eye is round and the blade is thin with no molding at its base. It is engraved on the obverse side with a stylized tree and on the reverse with a five-pointed star. The haft, which is 
more recent, is of highly polished light-colored wood with a lead fore-end cap and mouthpiece. Collected from the Shawnee.

$\mathrm{H}: 6 \frac{1}{8}^{\prime \prime} \mathrm{W}: 2 \frac{1}{4}^{\prime \prime} \mathrm{L}: 13 \frac{7}{8}^{\prime \prime}$

MAI/HF : IO/2888

186. Pipe tomahawk, (ca. I850-1870). In this remarkable specimen the form tomahawk most popular from I 860 to I 880 is almost completely developed. The tall bowl, almost imperceptibly barrel shaped, with a simple molding at top and bottom, the high median ridge opposite the center of the eye, and the thin blade flaring symmetrically with straight sides all are characteristic of the type. In this instance the bowl moldings have been filed octagonal, and the eye itself is still a pointed ellipse rather than a true diamond. The blade has been sharpened, which is not usual; and in this instance a considerable portion of the blade has been ground away through repeated sharpenings, perhaps as much as an inch and a half. It is engraved with scratchwork borders and a circle. The haft is most unusual with the protuberances on top and the branch below. There are brass tacks on the top of each of the protuberances and in an X pattern just behind the head. The bands and diamond inlays are silver and are engraved with scratchwork decoration; some of these are replacements. The fore-end cap is pewter, and the mouthpiece is lead. Collected from the Kickapoo in Coahuila Mexico, it was probably taken with them when they fled south in $185^{2}$ or in 1863 . See No. 152.

$\mathrm{H}: 8^{\prime \prime} \mathrm{W}: 2 \frac{7^{\prime \prime}}{8} \mathrm{~L}: 19^{\prime \prime}$

MAI/HF : $2 / 6862$

187. Pipe tomahawk, (ca. I860-1880). This is the large classical so-called Plains Indian tomahawk in its simplest basic form. It belonged to the Hunkpapa Sioux chief, Big Foot, who was killed in the Wounded Knee Massacre, December 29, I890. Later examples illustrate various embellishments and variations. The eye is diamond shaped, and there is a sharp median ridge on the outside, opposite the lateral points of the diamond. The bowl is tall, slightly barrel shaped, with simple top and bottom moldings. Its pointed base moldings extend to the median ridge. There are filed moldings at the juncture of the blade and eye, and there is a small projection to the rear at the base of the blade. The blade itself is thin and flares in straight lines both front and back so that it is almost symmetrical. The haft is file branded.

$\mathrm{H}: 9 \frac{3}{4}^{\prime \prime} \mathrm{W}: 4^{\frac{1}{4}}{ }^{\prime \prime} \mathrm{L}: 24^{\frac{11}{2}}$

$\mathrm{MAI} / \mathrm{HF}: 22 / 7225$

188. Pipe tomahawk, (ca. I860-1880). Here the classical features of the Plains Indian type have been embellished with stamping, engraving, and inlay. The tall bowl has double moldings at top and bottom instead of the more usual single bands. The exterior of the eye has the median ridge, but internally the eye itself is a teardrop instead of the more usual diamond. Two deep file lines follow the outline of the base molding of the bowl as it extends to the ridge of the eye. Other borders throughout the piece are composed of stamped circles and crescents. The center of the blade bears a conventionalized flower inlaid in brass on the reverse side, and the same design is engraved on the obverse. Above it is a cartouche formed by the stamped circles and crescents and shaded with scratchwork engraving. On the lower half of the eye area below the ridge is a trefoil in scratchwork. The haft is rough with the whittling marks visible. It has been file branded, and the lower edge near the head has been carved in a series of serrations. Attributed to the Oto.

$\mathrm{H}: 8 \frac{3^{\prime \prime}}{}{ }^{\prime \prime} \mathrm{W}: 3 \frac{7^{\prime \prime}}{8} \mathrm{~L}: 2 \mathrm{I}^{1 \prime \prime}$

MAI/HF : $20 / 7859$ 
189. Pipe tomahawk, (ca. I860-I880). In this specimen several variants of the standard form have been introduced. The bowl is heavier, faceted, and stamped with a sunburst decoration in the center of each facet. There is no true base molding for the bowl, and this has been simulated by filed lines on the strap forming the eye. The blade has a straight forward line and flares only to the rear, thus making it narrower than most, and it is pierced with a single circular hole. The haft is wrapped with brass wire for two-thirds of its length, and there is a buckskin sleeve at the mouth end with narrow beaded bands and a fringe. A pewter fore-end plate is held in place with brass tacks. Collected in Oklahoma from the Comanche.

$\mathrm{H}: 8 \frac{1}{8}{ }^{\prime \prime} \mathrm{W}: 2 \frac{1}{2}{ }^{\prime \prime} \mathrm{L}: \mathrm{I} 9 \frac{1}{2}{ }^{\prime \prime}$

MAI/HF : $2 / 4423$

190. Pipe tomahawk, ( $c a$. I860-I880). This specimen is typical in all respects, except that the blade is narrower than the average. Crude filed X's have been placed below the ridge of the eye, and there is a series of short vertical lines engraved across the base of the blade. The haft is quite recent. Attributed to the Comanche.

$\mathrm{H}: 8 \frac{3}{4}^{\prime \prime} \mathrm{W}: 3^{\prime \prime} \mathrm{L}: 22^{\prime \prime}$

MAI/HF : 20/2O2I

191. Pipe tomahawk, (ca. I860-I880). In this specimen the basic Plains Indian form has been embellished by piercing. The eye is oval rather than diamond, and the base moldings of the blade have been forged rather than lightly filed. The haft has a buckskin sleeve near the mouthpiece decorated with quill work, a flap, and long fringe. Attributed to the Sioux.

$\mathrm{H}: 9 \frac{3^{\prime \prime}}{8} \mathrm{~W}: 4 \frac{1}{8}^{\prime \prime} \mathrm{L}: 23 \frac{1}{4}^{\prime \prime}$

MAI/HF : 20/I26I

192. Pipe tomahawk, (ca. I860-I880). This specimen also is narrower than the classic form of No. I87. It is also pierced with a heart and bears interesting scratched engraving depicting two Indians on each side. The haft is wrapped for most of its length with brass wire. At the mouth end a buckskin thong passes through a hole and attaches a small beaded flap with a braided scalp of light-colored hair. Collected from the Blackfoot.

$\mathrm{H}: 8 \frac{1}{2}^{\prime \prime} \mathrm{W}: 2 \frac{5}{8}^{\prime \prime}$ L: $16 \frac{7}{8}^{\prime \prime}$

MAI/HF : $20 / 9657$

193. Pipe tomahawk, (ca. I860-1880). A large typical specimen of the Plains type embellished with a pierced heart, the point slightly bent. The haft is studded with brass tacks in double bands and cross patterns. It has also been file branded. A long strip of fox fur and some remnants of red cloth are suspended from a hole at the mouth end. Apparently there was a separate mouthpiece, which is now missing. From the Crow in Montana.

$\mathrm{H}: 9 \frac{1}{2}^{\prime \prime} \mathrm{W}: 3 \frac{5}{8}{ }^{\prime \prime} \mathrm{L}: 2 \mathrm{O}^{\prime \prime}$

MAI/HF : IO/3I 57

194. Pipe tomahawk, (ca. I860-I880). A very crude specimen of the Plains type with an oval eye. The pipe bowl has no neck and has been bent slightly backward. The blade has been pierced with a cross, each end of which terminates in a circle. The haft is file branded and studded with brass tacks in bands. The lower edge near the head has been carved in a series of serrations. The mouthpiece is made from a .38 caliber cartridge case. Attributed to the Oglala Sioux.

$\mathrm{H}: 9 \frac{1}{8}^{\prime \prime} \mathrm{W}: 3 \frac{1}{2}^{\prime \prime} \mathrm{L}: 23 \frac{1}{2}^{\prime \prime}$ MAI/HF : I $3 / 7843$ 
195. Pipe tomahawk, (ca. I860-1880). A large, very well-forged example of the Plains type with a heart piercing in the blade. The haft is file branded and studded with brass tacks principally in bands. From the Oglala Sioux.

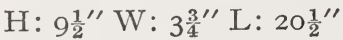

$\mathrm{MAI} / \mathrm{HF}: 20 / 4899$

196. Pipe tomahawk, ( $c a$. I860-I880). A well-forged specimen of classical Plains type with a pierced heart design in the blade. The haft has been carved in an unusual fashion with flats along the sides for the forward twothirds of its length. Then a series of three notches, almost dovetailed in form, have been fashioned, perhaps for finger grips. There are a few brass tacks, and the mouthpiece is made from a copper cartridge case originally of . 44 or . 45 caliber. It was collected from the Santee Sioux.

$\mathrm{H}: 7 \frac{5}{8}^{\prime \prime} \mathrm{W}: 3 \frac{1}{2}^{\prime \prime} \mathrm{L}: \mathrm{I} 9 \frac{1}{2}{ }^{\prime \prime}$

$\mathrm{MAI} / \mathrm{HF}: 20 / 2829$

197. Pipe tomahawk, (ca. I860-I880). An extremely large example of the Plains type. The head is in the classical form in all respects. The haft appears more recent and is unadorned except for a quantity of brass tacks. Attributed to the Shoshoni.

$\mathrm{H}: \mathrm{IO}^{\prime \prime} \mathrm{W}: 4^{1 / \prime} \mathrm{L}: 23^{\prime \prime}$

$\mathrm{MAI} / \mathrm{HF}: \mathrm{I} 2 / 3200$

198. Pipe tomahawk, (ca. I860-I880). A slightly atypical form in that the blade does not flare symmetrically, and the edge is at an angle to the haft instead of roughly parallel to it. It is also embellished with scratchwork decoration comprising crossed arrows on the eye area below the ridge on both sides, a conventionalized flower on the reverse of the blade, and a bird's head on the obverse. The haft appears to have been branded with a sharp-toothed rasp. The mouthpiece is a separate piece of wood. Attributed to the Blackfoot.

$\mathrm{H}: 8^{\prime \prime} \mathrm{W}: 3^{\frac{3}{4}} \mathrm{~L}: 22^{\prime \prime}$

$\mathrm{MAI} / \mathrm{HF}: 22 / 4846$

199. Pipe tomahawk, (ca. I860-I880). A large crude version of the Plains type, inlaid on the obverse side of the blade with a silver cross and a copper crescent. The eye is round, and the outer surfaces of it are not well formed. There is no median ridge, and the moldings on the bowl are barely indicated. The haft is rough and apparently branded with a rasp. Attributed to the Santee Sioux.

$\mathrm{H}: 9 \frac{1}{4}^{\prime \prime} \mathrm{W}: 3 \frac{14^{\prime \prime}}{} \mathrm{L}: 2 \mathrm{O}^{\prime \prime}$

MAI/HF: 2I/I 295

200. Pipe tomahawk, (ca. I890-1910). Generally in the traditional Plains Indian form, this specimen is machine made and modern in appearance. The eye is oval, though there is a ridge on the outside. This portion still bears traces of red paint as does the base of the bowl. The haft bears a zig-zag groove, painted red, running for most of its length. Rawhide thongs are wrapped around just before and behind the head and just before the mouthpiece. A string of miscellaneous beads is also wrapped around the haft just behind the head. Attributed to the Arapaho.

$\mathrm{H}: 7 \frac{7}{8}^{\prime \prime} \mathrm{W}: 3 \frac{12^{\prime \prime}}{} \mathrm{L}:$ I $8 \frac{14^{\prime \prime}}{}$

$\mathrm{MAI} / \mathrm{HF}: 20 / 7623$

201. Pipe tomahawk, (ca. I860-I880). A very large, but typical, specimen of the Plains type, closely resembling numbers I 87 and I97. Slight differences include a triple molding at the top of the bowl and a base molding that stops short of the ridge in the center of the eye. The haft is plain except 
for a buckskin thong from which suspends a circle of red cloth decorated with bead work and trailing three tufts of hair in simulation of a scalp. Attributed to the Sioux.

$\mathrm{H}: 9 \frac{7}{8}^{\prime \prime} \mathrm{W}: 3 \frac{1}{2}^{\prime \prime} \mathrm{L}: 23 \frac{5}{8}^{\prime \prime}$

MAI/HF : $2 / 9679$

202. Pipe tomahawk, (ca. I870-1890). A huge tomahawk which shows some of the influence of the typical Plains Indian style, but varies greatly from it. It is beautifully forged and finished. The bowl is short and thick by Plains standards and is inlaid with two brass bands. There is almost no neck. At the base of the blade are three circular inlays of brass on each side. The blade itself is narrow and pierced with a circular hole that has bevelled edges. A more unusual feature is a beveled edge along the back of the blade. The haft has been burned in an all-over pattern of a leaf design, and a small section near the mouth end has been wrapped with copper wire as has a very short section just in front of the head. Another interesting fact is the presence of a protuberance with a hole drilled through it on the upper edge of the haft just behind the head. Usually these features are on the bottom of the haft, and this raises the question of whether the haft might have been inserted upside down at some point in its career. It could not have been recent, however, to judge by the wire wrapping in front of the head, and it may just possibly always have been this way. From this hole are suspended a string of beads and a scalp with some more beadwork around the fastening. This interesting specimen belonged to Chief Little Wolf of the Northern Cheyennes, a leader in the Sioux War of 1876.

$\mathrm{H}: \mathrm{II}^{\prime \prime} \mathrm{W}: 3 \frac{1}{2}{ }^{\prime \prime} \mathrm{L}: 24 \frac{14^{\prime \prime}}{}$

$\mathrm{MAI} / \mathrm{HF}: 3 / 5353$

203. Pipe tomahawk dated $\mathrm{I} 895$. A most unusual specimen that may possibly be fraternal, rather than actually meant for Indian use. The bowl is without moldings and sits on a long neck slanted back. It is inlaid in brass "F F \& C / I 895" in two lines. The eye is oval, and on either side is inlaid a crude drawing of an Indian's head. The blade is inlaid on the obverse with an American eagle, stars, and the word "TOTE" as if this decoration had been inspired by one of the early axes such as No. I24. The reverse side has a design of arms consisting of a hatchet, pipe, knife and club in brass inlay. The haft is completely plain. Provenience unknown.

$\mathrm{H}: 8^{\prime \prime} \mathrm{W}: 3 \frac{1{ }^{\prime \prime}}{4} \mathrm{~L}: 2 \mathrm{I}^{\prime \prime}$

MAI/HF : 22/72IO

204. Recent pipe tomahawk. This specimen was undoubtedly made after I 900 and may well have been designed for fraternal use. It is cast iron with a simple stovepipe bowl and a round eye. It is decorated in relief on the obverse side with an arrow, its head on the pipe bowl and its shaft running down the bowl, over the eye and terminating in the feathers on the base of the blade. On the blade itself is an Indian head. On the reverse side are a bear and a snake. The haft is carved along its upper edge with a turtle and an Indian head, and there are various notches. There is also some evidence of charring, perhaps in an attempt to simulate age. Collected in Nebraska. $\mathrm{H}: 7 \frac{3}{8}^{\prime \prime} \mathrm{W}: 2 \frac{14^{\prime \prime}}{4} \mathrm{~L}:$ I9 $\frac{3^{\prime \prime}}{}{ }^{\prime \prime}$

$\mathrm{MAI} / \mathrm{HF}: 22 / 7233$

205. Recent pipe tomahawk. Another cast iron specimen probably made after I9oo. The eye is round, and the workmanship is crude. The haft is simple with an arrow incised on the obverse side and a sun on top. There are traces of green paint and of some charring. Attributed to the Seneca. $\mathrm{H}: 7^{\frac{1}{2}}{ }^{\prime \prime} \mathrm{W}: 2 \frac{1{ }^{\prime \prime}}{}{ }^{\prime \prime}$ L: $16 \frac{1}{2}^{\prime \prime}$ $\mathrm{MAI} / \mathrm{HF}: 22 / 7276$ 
206. Recent pipe tomahawk. An excessively crude wrought-iron specimen undoubtedly made after I90o. The eye is teardrop and tapers towards the front instead of to the rear, as in almost all bonafide specimens. The haft is carved with a large turtle which has been painted a dull red. The remainder of the haft is painted black. An interesting addition is an antler plug in the fore end. Provenience unknown.

$\mathrm{H}: 7 \frac{3}{8}^{\prime \prime} \mathrm{W}: 2 \frac{1{ }^{\prime \prime}}{} \mathrm{L}: 2 \mathrm{I}^{\frac{5}{8}}$

MAI/HF : 22/7300

207. Pipe tomahawk (ca. I860-1880). A classical example of the so-called Plains Indian tomahawk in its simplest form, this specimen belonged to the Bannock chieftain Little Taighe from whom it was purchased in 1885 . The eye is diamond shaped and there is a sharp median ridge on the outside. The bowl is tall and slightly barrel shaped with simple moldings at the top and bottom. Its pointed base moldings extend almost to the median ridge. There are filed moldings at the juncture of the blade and eye, and there is a small projection to the rear at the base of the blade. The haft is decorated with file branding and two double rings of brass-headed tacks. There is a separate mouthpiece of bone.

$\mathrm{H}: 8 \frac{3}{8}^{\prime \prime} \mathrm{W}: 3 \frac{5}{8}^{\prime \prime} \mathrm{L}: 20 \frac{3}{8}^{\prime \prime}$

MAI/HF : 22/7300

208. Pipe tomahawk said to have belonged to Little Turtle, the famous Miami chieftain (I752-I8I2). The bowl is tall, but heavy, with a thick neck. It is slightly barrel shaped, with moldings at top and bottom. The eye is a rough oval, almost rectangular, with rounded corners, and the relatively narrow blade is straight sided with a gradual flair to the rear. The haft is cigar shaped with a protuberance on the lower edge near the mouthpiece. Decorations consist of silver and pewter inlays. There is a pewter fore-end cap and a pewter mouthpiece, both cast in place. Style and construction details seem to indicate a date in the $1820-1840$ period, since both the the bowl and the blade are early versions of the so-called "Plains Indian" form, which became popular after 1850 .

$\mathrm{H}: 6 \frac{1}{4}^{\prime \prime} \mathrm{W}: 2^{\prime \prime} \mathrm{L}: \mathrm{I} 7 \frac{3}{4}^{\prime \prime}$

$\mathrm{MAI} / \mathrm{HF}: 22 / 7207$

\section{Brass Heads with Steel Edges}

209. Pipe tomahawk with date $\mathrm{I} 760$. If the date engraved on this specimen indicates the year of manufacture, as it well may, this is the earliest known brass tomahawk with an inset steel edge. The bowl is taller than normal for this era and slopes slightly backward. Much of this height, however, is caused by the long neck. Otherwise the faceted bowl, tapering in to the moldings at the top, is in keeping with the style of the period. The eye is teardrop. The blade has the rearward flare in a concave line that one would. expect, but in this instance both front and back lines have been broken by decorative filing and curving lines. There is also a bevel simulating an edge on both the front and back for a distance of approximately one-third of the blade's height. The steel edge is not dovetailed but apparently is fitted into a groove in the brass and soldered. The reverse side of the blade is engraved with a set of scales. The date 1760 appears just below the bowl. The haft has a raised carving of a fleuv-de-lys adjacent to the head on its lower edge. There are two pewter bands, and the mouthpiece is pewter. It was collected from an elderly Mohawk.

$\mathrm{H}: 5 \frac{3}{8}^{\prime \prime} \mathrm{W}: 2^{\prime \prime} \mathrm{L}: \mathrm{I} 7 \frac{1}{4}^{\prime \prime}$

$\mathrm{MAI} / \mathrm{HF}: 3 / 48 \mathrm{I} 2$ 
210. Pipe tomahawk, late $\mathrm{I} 8$ th century. This is one of the commonest forms of brass tomahawk with dovetailed steel edge. The shallow rounded bowl has a conventionalized holly wreath engraved around it. There are raised horizontal moldings across the eye just below the neck, an engraved border, and conventionalized floral motif in the center of the eye. The border continues along the front and back of the blade, and down the center is engraved a single floral spray. Minor details vary, but this general pattern of decoration is found on almost all pipes of this form. The eye is round. The haft is completely modern and, although of fine workmanship, does not resemble any known pattern of the period. This specimen was collected among the Chippewa.

$\mathrm{H}: 7 \frac{3}{8}^{\prime \prime} \mathrm{W}: 2 \frac{5}{8}{ }^{\prime \prime} \mathrm{L}: \mathrm{I} 7 \frac{1}{2}^{\prime \prime}$

MAI/HF : 22/72I2

211. Pipe tomahawk, late $\mathrm{I} 8$ th century. Of the same general pattern as the preceding, this specimen has differences in decorative detail, and one structural difference. The engraving is slightly cruder. There is no wreath around the bowl, but a border of chevrons just above the bottom molding. These same chevrons compose a border in a rectangle on the eye area formed by the bottom line of the base molding of the bowl and the top line of the molding at the junction of the blade and eye. There are wavy line borders along the front and back of the blade and chevrons across the top. In the center is a floral pattern consisting of a center and five petals. The structural difference consists of eight brass rivets which pass through the blade just above the steel edge. The eye is teardrop. The haft appears to be old, but is not original. It is cut down to enter the eye and also lacks the thin leather gasket that should seal the joint between the haft and the head in a pipe of this period. Provenience unknown.

$\mathrm{H}: 7 \frac{1}{8}^{\prime \prime} \mathrm{W}: 2 \frac{3}{4}^{\prime \prime} \mathrm{L}: 2 \frac{1}{4}^{\prime \prime}$

Author's collection

212. Pipe tomahawk, late 18 th or early Igth century. Although this axe is more crudely made, its relationship to the two preceding specimens can easily be seen, especially in the shape of the bowl. The eye area is not delineated, but slopes from a relatively broad poll in an almost uniform taper to the edge. The eye itself is a modified teardrop. The steel edge is quite narrow and is attached to the brass head by three rivets. Provenience unknown.

$\mathrm{H}: 7^{\prime \prime} \mathrm{W}: \mathrm{I}^{7 \prime \prime}$

William 0 . Sweet collection

213. Pipe tomahawk marked J. Welshrans, (ca. I8Io-I820). A simple but exceptionally well-made specimen with a small round eye. The bowl is threaded and unscrews. The edge is dovetailed into the head. An interesting feature is the loop which projects from the back of the blade. It quite possibly may have been intended for one of the ceremonial chains of friendship. The haft is curly maple. This specimen was found in an attic in York, Pennsylvania.

$\mathrm{H}: 7^{\prime \prime} \mathrm{W}: 2 \frac{3{ }^{\prime \prime}}{} \mathrm{L}: \mathrm{I}_{5} \frac{1}{2}^{\prime \prime}$

Joe Kindig, Jr., collection

214. Pipe tomahawk, (ca. I8I5-I825). Another of the specimens with a small round eye, this one is only five-eighths of an inch in diameter. In view of the weakness inherent in any haft passing through so small an eye, the piece must have been entirely ceremonial. Thus the addition of a functional steel edge is most puzzling. Except for moldings on the bowl and neck, the piece is completely plain. Provenience unknown.

$\mathrm{H}: 7^{\prime \prime}{ }^{\prime \prime} \mathrm{W}: 2 \frac{1}{8}^{\prime \prime}$

Author's collection 
215. Pipe tomahawk with removable hammer head, (ca. I820-1850). This is a unique specimen in several ways. The inside of the pipe bowl is threaded to receive an iron insert which converts it to a hammer poll. A few other instances are known in which a spike can be substituted for the bowl, but in these specimens the entire bowl is removed and the spike attached in its place; also, these have been specimens with iron or steel heads. Another unique feature of this axe is the complicated design of the inset steel edge, with an urn motif and two small dovetails. There is a finely engraved wreath around the center of the bowl. The eye is oval and there is a very thin leather gasket. The haft is painted vermilion. The mouthpiece is horn, fastened with brass pins, and the plug at the front end is also horn. Provenience unknown.

$\mathrm{H}: 8^{\prime \prime} \mathrm{W}: 2 \frac{5}{8}^{\prime \prime} \mathrm{L}: 2 \mathrm{O}_{ \pm}^{\prime \prime}$

Robert Abels collection

216. Pipe tomahawk, (ca. I860-I880). A late specimen with a very tall straight-sided bowl much resembling the cup of a candlestick. The blade is pierced with two circles and an inverted heart. The steel edge, very narrow and cusped in the center, appears to be secured only with silver solder. The eye is round; the haft completely plain. Collected among the Cheyenne.

$\mathrm{H}: 7 \frac{3}{4}^{\prime \prime} \mathrm{W}: 3 \frac{3}{4}^{\prime \prime} \mathrm{L}: 19 \frac{3}{4}^{\prime \prime}$

Smithsonian Institution USNM : 178877

217. An unusually elaborate and heavy pipe tomahawk of excellent workmanship, late Igth century. The casting of the brass portion of the head, deeply grooved with geometrical patterns, suggests some of the wall decorations of the late Victorian era. The steel edge is heavy and comes up almost to the eye where it is inserted in a socket in the brass. The eye is oval. The haft appears to be walnut, and has a small, carefully worked mouthpiece. A buckskin thong is tied to a groove at the butt. According to its records, the Museum obtained this specimen in I9I3 from a retired Birmingham, England gun worker, then 84 years old. He said his father used to go to America to get orders for flint-lock guns between I8I3 and I833 and, on one occasion, was given this tomahawk by a Blackfoot chief. $\mathrm{H}: 9 \frac{3}{8}^{\prime \prime} \mathrm{W}: 4^{\prime \prime} \mathrm{L}: 22 \frac{1}{4}^{\prime \prime}$

$\mathrm{MAI} / \mathrm{HF}: 3 / 2906$

218. Pipe tomahawk, (ca. I860-I890). A late but well-made and moderately functional specimen. The steel edge is long and fits into a groove in the brass just below the eye where it is silver soldered in place. There is a pewter band just behind the head with a serrated edge. A similar one just in front of the carved mouthpiece is now missing. The haft itself is curved in a manner reminiscent of the felling axe of the same era. This was obtained in Idaho from the Nez Percé.

$\mathrm{H}: 7^{\prime \prime} \mathrm{W}: 3^{\frac{11}{4}} \mathrm{~L}: 22 \frac{3}{4}^{\prime \prime}$

$\mathrm{MAI} / \mathrm{HF}: 20 / 4922$

219. Pipe tomahawk, (ca. I900-I9I0). This specimen qualifies for inclusion in the brass and steel group only because its bowl is brass. This feature is screwed into a wrought iron strap which forms the eye. A thin steel blade is sandwiched between the ends of this strap. The eye itself is teardrop. The haft is flattened along the sides for about two-thirds of its length and has a series of vertical lines scratched into its surface. Attributed to the Osage.

$\mathrm{H}: 7^{\frac{3}{4}}=\mathrm{W}: 4^{\frac{1}{4}}$ MAI/HF : $20 / 4927$ 


\section{All-Brass Heads}

220. Pipe tomahawk, (ca. I850-1880). An early version of the Plains type with a straight-fronted blade. The eye is teardrop. The bowl is tall and straight sided with milled moldings top and bottom. The blade is pierced with three circular holes. The haft is straight and plain except for a few brass tacks and a rawhide thong. This axe was obtained from Chief Joseph of the Nez Percé when he was at Fort Leavenworth in 1877 .

$\mathrm{H}: 8 \frac{1}{2}^{\prime \prime} \mathrm{W}: 3 \frac{3}{8}^{\prime \prime} \mathrm{L}: \mathrm{I} 8 \frac{3}{4}^{\prime \prime}$

MAI/HF : $22 / 7235$

221. Pipe tomahawk from the battlefield of Fallen Timbers, Ohio, I 794. The eye is round. The bowl is short with a central molding, and the general casting is crude. The only decoration consists of the moldings and incised chevrons which were part of the original pattern. An identical specimen, now in the Stark County Museum, at Springfield, Ohio, was found on the site of the Greenville Treaty of 1795 .

$\mathrm{H}: 7^{\frac{1}{4}}{ }^{\prime \prime} \mathrm{W}: 3 \frac{12^{\prime \prime}}{}$

LaDow Johnston collection

222. Pipe tomahawk, late $\mathrm{g}$ th century. The head is cast from a well-made pattern but roughly finished with the file marks still visible, especially on the blade. The eye is round. The bowl is exceptionally tall with a series of turnings and moldings. The area of the eye is faceted instead of rounded, and there are double file lines simulating the usual base molding for the bowl. The long narrow blade is pierced with a heart. The haft is file branded and studded with brass tacks. A flap of red cloth with characteristic Blackfoot beaded decoration and buckskin fringe is tied just in front of the mouthpiece.

$\mathrm{H}: 9 \frac{1{ }^{\prime \prime}}{}{ }^{\prime \prime} \mathrm{W}: 2 \frac{3}{4}{ }^{\prime \prime} \mathrm{L}: 2 \mathrm{I} \frac{1}{8}{ }^{\prime \prime}$

$\mathrm{MAI} / \mathrm{HF}: 2 / 4424$

223. Pipe tomahawk, late Igth century. A simpler specimen than the preceding, its only decoration consists of the paneling around the eye and three knurled bands on the bowl. The eye is oval. The plus in the fore end is red cloth. Collected from the Kaw in Oklahoma.

$\mathrm{H}: 7 \frac{14^{\prime \prime}}{} \mathrm{W}: 2 \frac{3^{\prime \prime}}{4} \mathrm{~L}: 2 \mathrm{I}_{4}^{1 \prime \prime}$

$\mathrm{MAI} / \mathrm{HF}: 2 / 7 \mathrm{I} 28$

224. Pipe tomahawk, mid-rgth century. An earlier specimen than the two preceding ones, this axe possesses an interestingly faceted bowl with exceptionally thick walls which sits on a high base above the poll. The haft is modern. Collected in Montana from the Piegan Blackfoot.

$\mathrm{H}: 7 \frac{1^{\prime \prime}}{1} \mathrm{~W}: 2 \frac{3}{4}^{\prime \prime} \mathrm{L}: \mathrm{I} 4 \frac{1}{2}^{\prime \prime}$

$\mathrm{MAI} / \mathrm{HF}: 20 / 49 \mathrm{IO}$

225. Pipe tomahawk, late Igth century. Probably made in France, this specimen demonstrates considerable craftsmanship and imagination, but it is doubtful if it was actually intended for an Indian. In many respects it resembles the wall decorations of the late Victorian era. The bowl is huge. The eye is drilled through a solid cube, and the blade bears raised floral decorations. Immediately behind the head is a brass band fastened in place with a screw. The haft is ebony, and the turned mouthpiece is bone. Tribe unknown.

$\mathrm{H}: 5^{\frac{1}{2}}{ }^{\prime \prime} \mathrm{W}: 4^{\prime \prime} \mathrm{L}: 2 \mathrm{I} \frac{1}{8}^{\prime \prime}$

MAI/HF : $2 I / 4485$

226. Pipe tomahawk, late Igth century. In some ways this specimen resembles those with narrow-waisted blades which were popular at mid- 
century. The very tall bowl without a top molding, however, immediately stamps it as belonging to the late years of the century or possibly even to the opening years of the next. It is roughly cast with many sand pits. The edges have been nicked with a file here and there for decoration. Follow lines are engraved along the front and back of the blade, and a floral decoration is engraved in the center. The eye is a pointed ellipse. The haft is completely wrapped with brass wire. There is a pewter mouthpiece, fore-end cap and head bands, and an engraved silver band near the mouthpiece. Attributed to the Shawnee.

$\mathrm{H}: 8^{\prime \prime} \mathrm{W}: 3^{\prime \prime} \mathrm{L}: 23 \frac{1}{8}^{\prime \prime}$

$\mathrm{MAI} / \mathrm{HF}: 20 / 740 \mathrm{I}$

227. Pipe tomahawk, late Igth century. Another of the very late bronze castings with an extremely tall bowl and no top molding. In this instance the eye area is faceted, and the blade shape is quite decadent without even a hint of functionalism. The eye is round. The fore-end plug is turned wood. The haft itself is file branded and studded with brass tacks in a chevron pattern. Attributed to the Oglala Sioux.

$\mathrm{H}: 9^{\prime \prime} \mathrm{W}: 2 \frac{3^{\prime \prime}}{4} \mathrm{~L}: 24 \frac{1}{4}^{\prime \prime}$

$\mathrm{MAI} / \mathrm{HF}:$ I $3 / 7845$

228. Pipe tomahawk, late I9th century. Although this axe belongs to the same general group as its two predecessors, it is distinguished by a more elaborately formed bowl which boasts two inlaid copper rings. The eye is oval. The haft has a scalloped lower edge and is file branded. At one time it apparently had two inlays in the form of pointed ellipses. The mouth end is wrapped in strips of red-brown fur, apparently from a fox. From the Menomini in Wisconsin.

$\mathrm{H}: 7 \frac{7}{8}^{\prime \prime} \mathrm{W}: 3^{\prime \prime} \mathrm{L}: \mathrm{r} 8 \frac{1}{4}^{\prime \prime}$

MAI/HF : $10 / 2876$

229. Pipe tomahawk, late I9th century. A crudely-fashioned specimen of the late cast brass type with many file marks still visible. The bowl is once again the very tall form without top molding. The eye is oval. The haft is file branded, and there is a long wire pick tied on with a piece of light cord. Attributed to the Oto in Oklahoma.

$\mathrm{H}: 8^{\prime \prime} \mathrm{W}: 2 \frac{7}{8}^{\prime \prime} \mathrm{L}: 15 \frac{1}{2}^{\prime \prime}$

$\mathrm{MAI} / \mathrm{HF}: \mathrm{I} 2 / 855$

230. Pipe tomahawk, late Igth century. This piece may well be slightly earlier than its predecessors, perhaps as early as I870-I88o. It is wide and heavy. The tall bowl has well-formed top and bottom moldings, and the eye is teardrop. The haft is carved with raised figures of Indians, buffalo, arrows, and geometric patterns. Attributed to the Kainah Blackfoot.

$\mathrm{H}: 7 \frac{3{ }^{\prime \prime}}{} \mathrm{W}: 3 \frac{34^{\prime \prime}}{4} \mathrm{~L}: 23 \frac{34^{\prime \prime}}{}$

MAI/HF : $20 / 493$ I

231. Pipe tomahawk by Horstmann, circa I9oo. In form this head generally resembles the narrow-waisted types of the mid-Igth century. The details of workmanship, the fact that it is cast brass and nickel plated, and that it is secured to the haft by a screw with its head on the reverse side, however, all seem to indicate a considerably later date. The practice of nickel-plating brass tomahawk heads does not seem to have become popular until approximately the turn of the century. The name "HORSTMANN/PHILa" is stamped in two lines at the base of the blade just above the notch on the reverse side. The haft is a most unusual shape with a turned wooden mouthpiece.

$\mathrm{H}: 7 \frac{5}{8}^{\prime \prime} \mathrm{W}: 2 \frac{3}{8}{ }^{\prime \prime} \mathrm{L}: \mathrm{I} 8 \frac{1}{2}^{\prime \prime}$

Mary R. duMont collection 
232. Pipe tomahawk, nickel-plated brass, circa I900. Very similar to the preceding specimen, except that it is unmarked and does not have the screw passing through the side of the head and into the haft. The haft also is Indian made, rather than manufactured for the trade. It is branded in bands with short vertical lines and X's burned-in between. The rear half is wrapped with a leather strip, and there is a beaded band at both ends of the wrapping. Two small feathers are tied to the rearmost band. Attributed to the Osage.

$\mathrm{H}: 7 \frac{5}{8}^{\prime \prime} \mathrm{WV}: 2 \frac{3}{8}{ }^{\prime \prime} \mathrm{L}: \mathrm{I} 8 \frac{3}{4}^{\prime \prime}$

MAI/HF : $20 / 4926$

233. Pipe tomahawk of nickel-plated brass by Levi St. Cyr, I908. This casting is similar in many respects to numbers 226 and 229 although the bowl is a little shorter and thicker. The eye is oval. The blade is stamped on both sides with a star surrounded by a double circle. Each line of the stamping is made up of a series of small arcs. Between the double lines of the circle appears the name "LEVI ST CYR / WINNEBAGO NEBR," and in the center of the star is the date I908. The haft is file branded, but is not pierced, so that it could not be smoked. Collected from the Winnebago, Nebraska.

$\mathrm{H}: 8^{\prime \prime} \mathrm{W}: 2 \frac{34^{\prime \prime}}{} \mathrm{L}: 22^{\prime \prime}$

$\mathrm{MAI} / \mathrm{HF}: \mathrm{I} 6 / 254 \mathrm{I}$

234. Pipe tomahawk of nickel-plated brass, probably by Levi St. Cyr, I908. The head is identical in all respects to the previous specimen, except that the star-and-circle mark does not bear the name or date. It is obviously from the same mold, and the stamp is the same. The haft is file branded and decorated with strips of fur, black glass beads, yarn, and brass bells. Collected from the Sauk and Fox tribe.

$\mathrm{H}: 8^{\prime \prime} \mathrm{W}: 3^{\prime \prime} \mathrm{L}:$ I9 $\frac{3}{4}^{\prime \prime}$

$\mathrm{MAI} / \mathrm{HF}: 2 / 48 \mathrm{I} 4$

235. Recent pipe tomahawk. The head is roughly cast and almost formless except for the bowl. The eye is oval. A cross-and-line border has been engraved on the blade and the corners have been file nicked for decoration. The haft is studded with brass-plated tacks and is carved with incised drawings of Indians, a tepee, wagon, sun, and stars. The mouthpiece is nickel-plated brass. Undoubtedly a 2 oth century product. Provenience unknown.

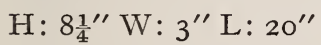

MAI/HF: $22 / 72$ I 5

236. Pipe tomahawk, (ca. I 900$)$. A simple brass casting that may possibly date from the very last years of the I9th century or as late as I920. The eye is round. The decoration consists of engraved lines along the front and back of the blade and along the base molding of the bowl plus a few stamped circles. The haft is not original. From the Sioux.

$\mathrm{H}: 7^{\prime \prime} \mathrm{W}: 2 \frac{3}{4}^{\prime \prime} \mathrm{L}: \mathrm{I} 8^{\prime \prime}$

$\mathrm{MAI} / \mathrm{HF}: 22 / 7234$

237. Recent pipe tomahawk. The head is a simple but well-made casting. The eye is oval, and there is no decoration. The haft tapers sharply in the reverse of the usual form; that is, it expands towards the mouth end. The head has been slipped over the fore end and slid down the haft to insure a tight fit; thus about one-fifth of the haft protrudes beyond the head. From this portion of the haft dangle brass bells on rawhide thongs, and strings of glass, shell, and horn beads, some of which seem to be prehistoric specimens. 
The mouthpiece is made from a cartridge case, apparently from the 1903 Springfield rifle. Attributed to the Mandan.

$\mathrm{H}: 6 \frac{5}{8}^{\prime \prime} \mathrm{W}: 2 \frac{1}{2}^{\prime \prime} \mathrm{L}: \mathrm{I} 6 \frac{1}{4}^{\prime \prime}$

$\mathrm{MAI} / \mathrm{HF}: 20 / 490 \mathrm{I}$

238. Recent pipe tomahawk. A more elaborate casting than most heads of this period, it may date from the closing years of the rgth century or as late as r9I0. There are floral decorations incised in the bowl and eye areas as part of the original casting. The blade bears miscellaneous punched dots and is engraved on the obverse side with a bear, and on the reverse side with the figure of an Indian. The eye is oval. The haft is completely modern. Provenience unknown.

$\mathrm{H}: 6 \frac{3^{\prime \prime}}{}{ }^{\prime \prime} \mathrm{W}: 2 \frac{7^{\prime \prime}}{8} \mathrm{~L}: \mathrm{I} 7 \frac{1}{2}^{\prime \prime}$

$\mathrm{MAI} / \mathrm{HF}: 22 / 7208$

239. Recent pipe tomahawk. A simple and crude casting with many sand pits and no decoration. It is certainly 2oth century. The eye is oval. The haft is studded with brass-headed tacks and wrapped for the first third of its length with a piece of buckskin held in place with some of these tacks. The remaining portion of the haft is branded with a series of crescents and lines which form bands around it. Attributed to the Winnebago.

$\mathrm{H}: 8^{\prime \prime} \mathrm{W}: 3_{4}^{1 \prime \prime} \mathrm{L}: \mathrm{I} 8^{\prime \prime}$

MAI/HF : $20 / 49$ I 5

\section{Pewter or Lead Heads}

240. Pewter pipe tomahawk, (ca. I775-1825). A well-made specimen with the shape of the late $\mathrm{I} 8$ th century. The bowl is short and of large diameter, tapering in slightly at the top. The eye is teardrop. Scratchwork borders have been engraved around the blade, and the name Wagaquan is engraved on the reverse side. The long slender haft is inlaid with pewter strapwork decoration just behind the head and before the mouthpiece, which is also pewter. Attributed to the Chippewa.

$\mathrm{H}: 6 \frac{14^{\prime \prime}}{} \mathrm{W}: 2 \frac{3}{4}{ }^{\prime \prime} \mathrm{L}: 22 \frac{1}{2}^{\prime \prime}$

$\mathrm{MAI} / \mathrm{HF}: \mathrm{I} 9 / 62 \mathrm{O} 2$

241. Very small pewter pipe tomahawk, late Igth century. With such small specimens, perhaps children's pieces, it is very difficult to be certain of a date since they do not necessarily follow the styles of contemporary pipes for adults. This particular specimen might well date from the first half of the century rather than from the second, but the straight sides of the bowl and the manner in which the blade springs from the eye area seem to outweigh the earlier features of the haft shape and the concave flare of the rear line of the blade. The eye is round. The haft is inlaid from end to end with bands of connected pewter diamonds. There are three eyelets along the lower edge of the haft, and from the first of these dangle long rawhide thongs wrapped in red, yellow, and blue quillwork, red feathers and horsehair dyed green. Attributed to the Blackfoot.

$\mathrm{H}: 4 \frac{1}{2}^{\prime \prime} \mathrm{W}: \mathrm{I} \frac{7}{8}{ }^{\prime \prime} \mathrm{L}: \mathrm{I} 2 \frac{1}{2}^{\prime \prime}$

$\mathrm{MAI} / \mathrm{HF}: 4 / 207 \mathrm{I}$

242. Crude pipe tomahawk of lead, late rgth century. The eye is round. The blade has been bent because of the softness of the material, and there are some rough solder repairs. The form of the bowl as well as the rear line of the blade reinforce the period attribution which might also be made on the basis of workmanship. There are two lead bands and a lead mouthpiece on the stem. Attributed to the Creek in Oklahoma.

$\mathrm{H}: 4 \frac{1}{2}^{\prime \prime} \mathrm{W}: \mathrm{I} \frac{7^{\prime \prime}}{\mathrm{L}} \mathrm{L}: 27^{3}{ }^{\prime \prime}$

$\mathrm{MAI} / \mathrm{HF}:$ IO $/ 2884$ 
243. Pewter pipe tomahawk, (ca. I880-I900). Another of the Plains Indian group, this time with unusual inlays in the blade despite the fact that the head itself is rather crudely cast. On the obverse side are four copper horseshoes. On the reverse are a brass tree and two C's. The eye is oval. The haft is studded with brass tacks and has been file branded. At the butt end is a sleeve with a beaded red cloth flap backed with buckskin and a cotton print. Attributed to the Cree.

$\mathrm{H}: 9 \frac{5}{8}^{\prime \prime} \mathrm{W}: 4^{\prime \prime} \mathrm{L}: 2 \mathrm{I}_{4}^{\frac{3}{4}}$

MAI/HF : 7/24I9

244. Very large pewter pipe tomahawk, (ca. I870-I890). Typical of the socalled Plains Indian form, but with a slightly later form of pipe bowl. The eye is round. The blade is decorated with dots punched in a V pattern and with five circular holes arranged in a square with one in the center. The haft may possibly be newer, but the decorations attached to the fore end are old. These consist of beads, feathers, and red cloth. The haft has not been pierced, so the pipe cannot be smoked. This was obtained from the Saulteaux Chippewa.

$\mathrm{H}:$ IO $\frac{3}{4}^{\prime \prime} \mathrm{W}: 4 \frac{1}{2}{ }^{\prime \prime} \mathrm{L}: 25^{\frac{1}{2}}$

MAI/HF : II/35OI

245. Pewter pipe tomahawk, (ca. I870-1900). Generally typical of the Plains Indian pattern, but with a small and decadent bowl. There is no decoration. The eye is rectangular, and the haft is file branded. Once again, it is not pierced and cannot be smoked. Collected among the Chippewa.

$\mathrm{H}: 7^{\frac{3}{4}}$ 'W: $3^{\frac{3}{4}}{ }^{\prime \prime} \mathrm{L}: 23^{\frac{1}{2}}{ }^{\prime \prime}$

$\mathrm{MAI} / \mathrm{HF}: 5 / 3707$

246. Pewter pipe tomahawk, (ca. I880-I900). A late and crude specimen collected in Tucson, Arizona, but certainly not used by any of the tribes in that immediate vicinity. The eye is rectangular, and this is reflected in the outside shape as well. Indications of the earlier pointed bowl base moldings have been filed on the sides, and the blade is pierced with a heart.

$\mathrm{H}: 7 \frac{1}{2}^{\prime \prime} \mathrm{W}: 3 \frac{1}{4}^{\prime \prime}$

William O. Sweet collection

247. Pewter pipe tomahawk, (ca. I880-I900). A late example of the Plains type in which the triangular piercing of the blade reaches the maximum of its development. The blade itself is reduced almost to straps. There is a heart inside a diamond in scratch engraving on the obverse side of the eye area. The eye itself is oval. The haft, which appears quite recent, is not pierced. It is, however, studded with brass tacks, and the butt end is wrapped with modern red cloth. Attributed to the Sisseton Sioux.

$\mathrm{H}: \mathrm{IO}^{\prime \prime} \mathrm{W}: 4^{\frac{3}{4}}{ }^{\prime \prime} \mathrm{L}: 25^{\frac{1}{2}}{ }^{\prime \prime}$

MAI/HF : $20 / 4906$

248. Pewter pipe tomahawk, (ca. I890-I900). The eye is large and round. The blade is pierced with a triangle, and the rear line of the blade is serrated. The haft is of the very short type sometimes found on late pipe axes. It is not pierced. For almost two-thirds of its length it is covered with rows of brass tacks; then it disappears into a beaded buckskin sleeve with a beaded flap, fringe, and brass bells. The beaded design is a late floral pattern. Attributed to the Crow.

$\mathrm{H}: 9 \frac{1}{2}^{\prime \prime} \mathrm{W}: 3 \frac{7^{\prime \prime}}{8} \mathrm{~L}: \mathrm{I} 5^{\prime \prime}$

$\mathrm{MAI} / \mathrm{HF}: 9 / \mathrm{I} 4 \mathrm{O} 4$

249. Pewter pipe tomahawk, (ca. I870-1890). Generally typical of the Plains Indian pattern, except that the eye is flat sided instead of having a sharp median ridge. The top and bottom moldings of the pipe bowl are 
cabled instead of being plain, and the base molding runs almost to the base of the blade. The most outstanding characteristic is the triangle piercing in the blade which seems to be quite common in pewter specimens of the late I9th century. Below it is engraved a tree. The haft has been burned in a spiral strip. There is a buckskin sleeve at the mouth with fringe and a beaded flap. Attributed to the Crow.

$\mathrm{H}: 9 \frac{1}{8}^{\prime \prime} \mathrm{W}: 4 \frac{3}{8}^{\prime \prime} \mathrm{L}:$ I $9 \frac{3}{4}^{\prime \prime}$

MAI/HF : $2 / 4425$

250. Pewter pipe tomahawk, (ca. I870-1890). Generally typical of the Plains Indian form, but with an octagonal eye and a simplified bowl. The blade is pierced with a diamond. The haft is studded with tacks and file branded. There is a cloth gasket around the haft inside the eye. From the Sioux.

$\mathrm{H}: 8 \frac{1}{4}^{\prime \prime} \mathrm{W}: 3^{\frac{3}{4}}{ }^{\prime \prime} \mathrm{L}: 19 \frac{1}{4}^{\prime \prime}$

$\mathrm{MAI} / \mathrm{HF}: \mathrm{I} 3 / 7844$

251. Pewter pipe tomahawk, (ca. I880-1900). Of the same general type as No. 246 , but more crudely made. The bowl is interesting because of its central band moldings and taper towards both ends. The eye is oval. Attributed to the Chippewa.

$\mathrm{H}: 8 \frac{1}{4}^{\prime \prime} \mathrm{W}: 2 \frac{7}{8}^{\prime \prime}$

$\mathrm{MAI} / \mathrm{HF}: 22 / 4847$

252. Pewter pipe tomahawk, late Igth century. A well-made specimen with complicated moldings and facetings on the tall straight bowl and over the eye. The eye itself is teardrop, and there is a cloth gasket around the haft inside it. The head sits well down the haft, and there is a bone plug in the fore-end which resembles the head of a walking stick. The mouthpiece is antler. The haft is plain. From the Wampanoag in Massachusetts.

$\mathrm{H}: 7 \frac{3}{4}^{\prime \prime} \mathrm{W}: 3 \frac{3^{\prime \prime}}{8} \mathrm{~L}: 3 \mathrm{O}^{\prime \prime}$

$\mathrm{MAI} / \mathrm{HF}: 22 / 7202$

253. Pewter pipe tomahawk, (ca. I880-1900). A crude specimen of the same general quality and type as numbers 246 and $25 \mathrm{I}$. The blade is pierced with a circular hole. The eye is oval. The haft is diamond shaped in section, is serrated along its lower edge and carved with incised chevrons on the two upper sides. At the mouth end is a buckskin socket attaching a beaded flap with long fringes of beads and plain buckskin. Attributed to the Hunkpapa Sioux.

$\mathrm{H}: 6 \frac{1}{2}{ }^{\prime \prime} \mathrm{W}: 2 \frac{1}{2}^{\prime \prime} \mathrm{L}: \mathrm{I} 6 \frac{1}{4}^{\prime \prime}$

MAI/HF : 22/7I99

254. Pewter pipe tomahawk, early Igth century. A small specimen, but well made in the style of the opening years of the century except for the straight-sided bowl. The eye is round. The haft is inlaid with silver diamonds, and there is a pewter mouthpiece. Attributed to the Chippewa.

$\mathrm{H}: 5^{\prime \prime} \mathrm{W}: \mathrm{I} \frac{7}{8}{ }^{\prime \prime} \mathrm{L}: \mathrm{I} 4 \frac{7{ }^{\prime \prime}}{}$

$\mathrm{MAI} / \mathrm{HF}: 3 / 4645$

255. Pewter pipe tomahawk, early Igth century. Another small specimen, but very nicely made with knurled moldings and incised diamond decorations. The bowl has been bent backward slightly. The eye is round. The haft is plain and the mouthpiece, probably originally of pewter, is now missing. The wire wrapped around the haft and head is modern, apparently designed to prevent the loss of the head. Attributed to the Fox in Iowa.

$\mathrm{H}: 5 \frac{14^{\prime \prime}}{} \mathrm{W}: \mathrm{I}_{4}^{\frac{3}{4}} \mathrm{~L}: \mathrm{I} 3^{\prime \prime}$

MAI/HF : $5 / 3708$ 


\section{Silver Heads}

256. Pipe tomahawk presented to Tom Hill in 1850 . This is the only silver or silver-plated tomahawk that has been observed in the course of the present study. It was impossible to determine which this is without scratching the specimen, which the museum was reluctant to do. If plate, it is extremely thick and well applied. No indication of any base metal could be detected, even on corners and edges. A strong magnet gave no reaction, removing the possibility of any ferrous metal being involved. The piece is well made, with a high oval eye. The bowl is tall and flares slightly toward the top. There is no real neck, but a short area below the bottom molding conveys this impression. The head is heavily engraved. The obverse side bears a sunburst on the outer surface of the eye with the date I850 (apparently by a different hand) beneath. On the blade is "TOM HILL / from / P. B. Reading," two clasped hands and "Peace \& Friendship." The maker's name, W. A. Woodruff, is stamped near the base. On the reverse side there is an eagle with the U. S. shield, a crescent moon, stars, and a design composed of a percussion gun, tomahawk, powder horn, and bow and arrow. The haft is walnut with a silver fore-end cap and mouthpiece and a wavy silver inlay along both sides. Hill was a Delaware Indian who went IVest in the I840's; he was with General Frémont in his fight with the native Californians in the Salinas Valley in I847 and was sent to Monterey for help. In that fight he lost his tomahawk, and Major Reading of Frémont's party had this one made as a present.

$\mathrm{H}: 8 \frac{1}{8}^{\prime \prime} \mathrm{W}: 3 \frac{3}{8}^{\prime \prime} \mathrm{L}: \mathrm{I} 8^{\prime \prime}$

Smithsonian Institution USNM: 362064

\section{Stone Heads}

257. Sandstone pipe tomahawk, late Igth century. A copy of a late specimen in soft sandstone, found in Indiana. The eye is round and does not pass all the way through the head.

$\mathrm{H}: 5 \frac{3}{4} " \mathrm{~W}: 2 \frac{1}{2}^{\prime \prime}$

$\mathrm{MAI} / \mathrm{HF}: 2 \mathrm{I} / 6004$

\section{PIPE TOMAHAWKS WITH SPONTOON BLADES}

\section{Iron or Steel Heads}

258. Early spontoon pipe tomahawk without basal processes, probably second half of the 18 th century and of French origin. The eye is teardrop and ample for a heavy haft, typical of this period. Originally the blade terminated in a point, probably turned slightly to the rear. Since this is now missing, measurements are given for the remaining portion. Provenience unknown.

$\mathrm{H}: 6 \frac{3}{4}^{\prime \prime} \mathrm{W}: \mathrm{I} \frac{3}{8}^{\prime \prime}$

William O. Sweet collection

259. Spontoon pipe tomahawk, (ca. I750-I780). Another of the early forms with ample teardrop eye and finely formed bowl. It was found in Michigan and is undoubtedly of French origin. This specimen has the basal processes which are commonly found on the spontoon blades. The neck was originally faceted. The point curves slightly to the rear.

$\mathrm{H}: 8 \frac{1}{2}^{\prime \prime} \mathrm{W}: \mathrm{I}_{\frac{1}{2}}^{\prime \prime}$

William O. Sweet collection 


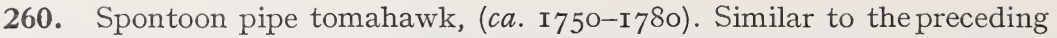
two specimens, but in better condition. The eye is large and oval with moldings above and below. The bowl is slightly irregular. The blade has lost part of one of the basal processes, and has been ground down considerably from its original shape. Found in Ohio, it is again probably French in origin.

$\mathrm{H}: 9 \frac{1}{4}^{\prime \prime} \mathrm{W}: \mathrm{r} \frac{1}{8}{ }^{\prime \prime}$

$\mathrm{MAI} / \mathrm{HF}: 2 \mathrm{I} / 2489$

261. Spontoon pipe tomahawk, (ca. I860-1880). The similarity between this and the Plains Indian form with an conventional blade can readily be recognized. The tall, slightly barrel-shaped bowl with the point of its base molding extending almost to the median ridge in the eye area, and the ribbed moldings are all typical of the era. In this specimen the base moldings are curled strongly around until the free ends touch the base of the blade, and there is a little scratchwork engraving. The eye is oval. The haft is studded with brass tacks and may well be later than the head. It is not pierced, so that the piece cannot be smoked. At the butt end are tied two long strips of fur, each with a beaded band two-thirds of the way towards its tip. Attributed to the Comanche.

$\mathrm{H}: 7^{\frac{3}{4}}{ }^{\prime \prime} \mathrm{W}: \mathrm{I} \frac{1}{2}{ }^{\prime \prime} \mathrm{L}: \mathrm{I} 5 \frac{1^{\prime \prime}}{}$

$\mathrm{MAI} / \mathrm{HF}: 2 / 4422$

262. Spontoon pipe tomahawk, (ca. 1850-1880). This specimen belongs to the same group as No. 26r. It differs, however, in having a bowl inlaid with two narrow copper bands and a blade that is finely forged with a strong median ridge running from just below the basal processes to the point. There is also a sunken band running across the outside of the eye where the median ridge would normally be. The eye itself is oval. The haft has two deep scallops cut from its lower edge and has incised designs of a cross and leaves. Tribe unknown.

$\mathrm{H}: 7^{\frac{1}{2}}{ }^{\prime \prime} \mathrm{W}: \mathrm{I}_{\frac{4}{4}}{ }^{\prime \prime} \mathrm{L}: \mathrm{I} 9^{\frac{3}{4}}{ }^{\prime \prime}$

MAI/HF : 22/7206

263. Spontoon pipe tomahawk, second half of the I8th century. The head is excavated, but the haft is quite modern. The bowl appears to have been faceted originally. The eye is large and of the teardrop form. The basal processes are rudimentary, but may at one time have been larger. Attributed to the Winnebago.

$\mathrm{H}: 8 \frac{7}{8}{ }^{\prime \prime} \mathrm{W}: \mathrm{I} \frac{1^{\prime \prime}}{}{ }^{\prime} \mathrm{L}: \mathrm{r} 8^{\prime \prime}$

MAI/HF : 20/49I4

264. Spontoon pipe tomahawk, (ca. I80o-181o). The eye is teardrop and. large. The bowl is slightly smaller and taller than on the earlier specimens. The blade is rather crudely forged, and the forward process is bent and its end broken. The haft is straight sided with one silver band, flaring to an oval medallion on top. Attributed to the Seneca.

$\mathrm{H}: 93^{3 \prime \prime} \mathrm{W}: \mathrm{I} \frac{5}{8}{ }^{\prime \prime} \mathrm{L}: \mathrm{I} 4_{4}^{1 \prime \prime}$

MAI/HF : I $5 / 8356$

265. Spontoon pipe tomahawk, first half of the rgth century. A crude forging with a diminutive blade and "processes" that are really pierced lobes. The eye is large and oval. The haft is apparently a replacement, but retains the original lead mouthpiece. Attributed to the Choctaw.

$\mathrm{H}: 6 \frac{1}{2}^{\prime \prime} \mathrm{W}: \frac{7{ }^{\prime \prime}}{8} \mathrm{~L}: \mathrm{I}_{\frac{1}{4}}{ }^{\prime \prime}$

MAI/HF : $732 \mathrm{I}$ 
266. Spontoon pipe tomahawk, (ca. $1825-1850)$. The eye is teardrop and relatively ample, but the bowl is tall, and the moldings on the sides of the eye area suggest those popular at mid-century. There are no basal processes. The haft is absolutely plain. Attributed to the Iroquois.

$\mathrm{H}: 6 \frac{1}{4}^{\prime \prime} \mathrm{W}: \mathrm{I}_{\frac{1}{2}}^{\prime \prime} \mathrm{L}: \mathrm{I} 5 \frac{7^{\prime \prime}}{}$

MAI/HF : I9/5088

267. Spontoon pipe tomahawk, late Igth century. The bowl of this large specimen is plain except for a single groove near the center. The eye is teardrop, and the outer surface reflects this shape. The blade is thin, without basal processes, and is pierced with a heart. The haft is file branded and studded with a few brass tacks near the head. At the mouth end there is a hole with a buckskin thong tied through it, and just ahead of this a long strip of light brown fur is tied to the haft. A green ribbon is tied around the neck of the pipe bowl. Attributed to the Crow.

$\mathrm{H}:$ Io $\frac{1}{4}^{\prime \prime} \mathrm{W}: 2 \frac{7}{8}^{\prime \prime} \mathrm{L}: 23 \frac{1}{4}^{\prime \prime}$

$\mathrm{MAI} / \mathrm{HF}:$ II $/ 5089$

268. Spontoon pipe tomahawk, (ca. I870-1890). A small and crude specimen of a type often called "Minnewauken" in the past. The characteristic of this form is the kite-shaped blade without basal processes. In this instance the blade is stamped with crescents, stars and leaves; the point is broken off. The bowl is excessively tall in proportion to its height. The haft is tall and thin with six notches cut in the lower edge near the mouthpiece and some slight scrolling along the top edge just above them. Attributed to the Nez Percé.

$\mathrm{H}: 7^{\prime \prime} \mathrm{W}: \mathrm{I} \frac{1^{\prime \prime}}{}{ }^{\prime \prime}$ : $16 \frac{3}{4}^{\prime \prime}$

MAI/HF : $20 / 4923$

269. Spontoon pipe tomahawk, (ca. I860-I880). Another tall specimen of the so-called Plains Indian type. The bowl and eye are well formed with a beaded molding along the median ridge. The eye itself is a pointed ellipse. The basal processes curve sharply upward, and their free ends touch the blade. Below, the blade is pierced with a heart, and punched dots form a border around the opening. The haft is plain except for a few tacks in the fore end. Attributed to the Osage.

$\mathrm{H}:$ IO" $\mathrm{W}: 2 \frac{1{ }^{\prime \prime}}{8} \mathrm{~L}:$ I9 $\frac{18^{\prime \prime}}{}$

$\mathrm{MAI} / \mathrm{HF}: \mathrm{IO} / 2890$

270. Spontoon pipe tomahawk, (ca. I860-1880). Also in the Plains Indian pattern, this specimen has an unusual bowl as far as spontoon pipes are concerned. It is tall, tapering inward toward the top with multiple narrow moldings. The basal processes curve sharply upward, and originally probably stopped just short of touching the blade with their free ends. The blade is pierced with a heart, and there are brass inlays consisting of a stylized tree, crescent moon, and stars on the obverse, and the same elements plus the letters CK on the reverse. The haft is plain except for a pewter headband and mouthpiece. Attributed to the Sioux.

$\mathrm{H}: 10^{\prime \prime} \mathrm{W}: 2 \frac{3}{8}{ }^{\prime \prime} \mathrm{L}: 16^{\prime \prime}$

$\mathrm{MAI} / \mathrm{HF}: 22 / 7204$

271. Spontoon pipe tomahawk, ( $c a$. I860-I880). This is the classicsocalled "Minnewauken" form with the kite-shaped blade almost a diamond. It is completely undecorated, but there is a slight median ridge running down the blade. The eye is a pointed ellipse, and there is no median ridge on the outside. The haft is absolutely plain. Provenience unknown.

$\mathrm{H}: \mathrm{IO}^{\prime \prime} \mathrm{W}: 2 \frac{1{ }^{\prime \prime}}{4} \mathrm{~L}: \mathrm{I} 3 \frac{3}{4}^{\prime \prime}$

$\mathrm{MAI} / \mathrm{HF}: 22 / 7292$ 
272. Spontoon pipe tomahawk, (ca. I890-19Io). This large specimen has several unusual features. The bowl is thick and sits on a high base. Around its center runs a broad knurled band, and the base itself is reeded horizontally. Most unusual, however, is the blade shape consisting of a diamond and then a barbed point. The eye is diamond shaped, and there is a sharp median ridge on the outside. The entire head is forged of soft iron. The haft is file branded and studded with brass tacks. It has been varnished. From a hole near the mouth end dangles a horsehair tassel with a beaded band at its base. Attributed to the Kiowa.

$\mathrm{H}: \mathrm{IO} \frac{1^{\prime \prime}}{} \mathrm{W}^{\prime}: \mathrm{I}^{3 \prime} \mathrm{L}: 20 \frac{1}{8}^{\prime \prime}$

MAI/HF : I9/7964

273. Spontoon pipe tomahawk, (ca. I860-1880). A crude specimen of the Plains type with various lines askew and numerous cracks and flaws in the metal. The bowl and the pointed ellipse eye with a median ridge on the outside conform in all respects to the type. The rear basal process of the blade retains its original curve; the forward one has been bent more acutely. A single circular hole pierces the blade just above its widest point. The haft is plain. Attributed to the Sauk and Fox.

$\mathrm{H}: 9 \frac{1}{2}^{\prime \prime} \mathrm{W}: 2^{\prime \prime} \mathrm{L}: \mathrm{I} 8 \frac{3}{4}^{\prime \prime}$

MAI/HF : I $8 / 8270$

274. Spontoon pipe tomahawk, (ca. I870-1900). A simply-forged specimen with the basal processes well down the blade, instead of almost directly at the base in the more usual fashion. The eye is oval. The bowl is lower and of larger diameter than most pipes of the period, and the blade is a thin sheet of iron. The haft is plain except for file branding. Attributed to the Cheyenne. $\mathrm{H}: 7^{\frac{3}{4}} \mathrm{~W}: \mathrm{I}_{2}^{1 \prime} \mathrm{L}: \mathrm{I} 8^{\prime \prime}$

MAI/HF : 22/7223

275. Spontoon pipe tomahawk, (ca. I880-1900). A crudely-made late specimen. The blade is a separate thin piece of iron welded between the two straps which form the eye. The eye itself is round. The bowl is exceptionally tall with straight sides and a flare outwards. The haft is diamond shaped in section and is file branded in a pattern of spiral stripes. The butt end is sheathed in a sleeve of buckskin with beaded decoration which attaches a beaded flap, fringe, and brass bells. Attributed to the Blackfoot.

$\mathrm{H}: 7 \frac{1}{8}^{\prime \prime} \mathrm{W}: \mathrm{I}_{\frac{3}{4}}^{\prime \prime} \mathrm{L}: 20 \frac{1}{4}^{\prime \prime}$

$\mathrm{MAI} / \mathrm{HF}: 20 / 49 \mathrm{I} 2$

276. Spontoon pipe tomahawk, (ca. I860-I880). This again is a classic example of the so-called "Minnewauken" blade. It is well but simply made with a straight-sided bowl and oval eye, and the kite-shaped blade without processes that characterizes the style. In this instance the blade has been stamped with a series of crescents and stars, and the edges of the eye have been filed to form a cusped border. The first third of the haft is wrapped with cord, and a fringe of buckskin is tied along the entire lower edge. Attributed to the Sauk and Fox.

$\mathrm{H}: 9 \frac{7}{8}^{\prime \prime} \mathrm{W}: 2 \frac{1}{2}^{\prime \prime} \mathrm{L}: \mathrm{I} 7 \frac{1}{2}^{\prime \prime}$

MAI/HF : $5 / 473$

277. Spontoon pipe tomahawk, (ca. 1880-1900). The pipe bowl has been broken off. The eye is round, and the blade is a thin sheet of iron with very long basal processes of almost fishhook shape, to judge by the one which survives. The blade is pierced with three circular holes arranged as a triangle, and there are punched dots all over the surface. The haft, which seems even more recent, is completely wrapped in what appears to be rabbit fur with three long strips pendant. Attributed to the Crow in Montana.

$\mathrm{H}: 8 \frac{1}{4}^{\prime \prime} \mathrm{W}: 2^{\prime \prime} \mathrm{L}: 23^{\prime \prime}$

MAI/HF: I2/64OI 
278. Spontoon pipe tomahawk, ( $c a$. I90o). A very crude specimen made of three pieces of iron brazed together. These comprise a simple tube for the bowl, a strap for the eye, and a sheet for the blade. It could not possibly be used for anything except decoration. The eye is teardrop. The haft seems even more recent than the head; it is carved with a series of grooves into which blue paint has been rubbed. Near the mouth end is a large tuft of horsehair and lengths of red, purple, and green cloth. Attributed to the Chippewa.

$\mathrm{H}: 7^{\prime \prime} \mathrm{W}: 2 \frac{1}{2}{ }^{\prime \prime} \mathrm{L}: 2 \mathrm{O}^{\prime \prime}$

MAI/HF : I $5 / 2978$

279. Spontoon pipe tomahawk, (ca. I860-I880). A well-made specimen with a faceted pipe bowl that unscrews. The eye is teardrop. There are no true basal processes, but projections just below the joint of the eye suggest rudimentary vestiges. The blade is pierced with four circular holes, and a series of engraved arcs and punched dots complete the decoration. Attributed to the Nez Percé.

$\mathrm{H}: \mathrm{IO}^{\prime \prime} \mathrm{W}: 2 \frac{3^{\prime \prime}}{8}$

MAI/HF : $14 / 735^{8}$

280. Late spontoon pipe tomahawk with leaf-shaped blade. The bowl is a simple tube, straight sided with a simple flaring molding at the top. The eye is almost round. An X is engraved on the outside of the eye, and a series of punched dots and engraved lines form a stilized tree on the blade. Attributed to the Chippewa.

$\mathrm{H}: 7 \frac{7}{8}^{\prime \prime} \mathrm{W}: 2 \frac{3}{4}^{\prime \prime}$

$\mathrm{MAI} / \mathrm{HF}: 19 / 4989$

281. Spontoon pipe tomahawk, mid-rgth century. An unusual specimen in that the strap which forms the eye is exceptionally narrow and thick, directly opposite from the more common proportion. The bowl is tall with a double molding at the top, and the blade is small but well formed. The eye itself is oval. The haft is file branded and the mouthpiece is lead. Attributed to the Sauk and Fox.

$\mathrm{H}: 7^{\frac{3}{4}}{ }^{\prime \prime} \mathrm{W}: \mathrm{I} \frac{3^{\prime \prime}}{\mathrm{L}} \mathrm{L}: \mathrm{I} 4 \frac{1}{4}^{\prime \prime}$

MAI/HF : 20/I990

282. Spontoon pipe tomahawk, (ca. I880-1900). One of the very longhafted types found at the very end of the I 9 th century. The head is probably a trifle earlier than the haft. The eye is diamond shaped and there is the external median ridge which is normal for this period. The bowl is faceted. The blade is leaf shaped with only rudimentary basal processes, and there is an elliptical copper inlay in the center. The haft is wrapped tightly in rawhide for most of its length. A braided thong with hair tassel is looped around the haft near the head, and another heavier one passes through a hole at the butt end. The haft is not pierced and cannot be smoked. It was collected from a Plains Indian; the specific tribe is not known.

$\mathrm{H}: 7 \frac{3}{4}^{\prime \prime} \mathrm{W}: 2 \frac{1^{\prime \prime}}{} \mathrm{L}: 32^{\prime \prime}$

Smithsonian Institution USNM: 361478

283. Spontoon pipe tomahawk, (ca. I900). A recent forging with kiteshaped blade, rectangular eye, and a flat circular face on the outside of the eye. In this instance the haft is also one of the extremely long, unpierced variety. In the fore end there is a screw with a short length of ribbon in place of the usual plug. The haft is wrapped in what appears to be rabbit fur for a short length just behind the head. Then follows a long section wrapped 
in copper wire with a section of light and dark blue and yellow beads in the center. The butt end is covered with a sleeve of red and black wool faggoting with loose ends of the yarn for a tassel. From the Piegan Blackfoot of Montana.

$\mathrm{H}: 63^{\prime \prime} \mathrm{W}: 2 \frac{1{ }^{\prime \prime}}{4} \mathrm{~L}: 29^{\prime \prime}$

Smithsonian Institution USNM: 153578

284. Unique spontoon pipe tomahawk with buffalo-head blade, (ca. I88oI900). In this highly imaginative specimen the basal processes have been converted to horns and the blade itself shaped to resemble a buffalo's head with a short straight beveled edge at the bottom. Four circular holes have been drilled to simulate the eyes and nostrils. The eye is rectangular both inside and out, and the neckless bowl expands slightly to the top with a simple molding. The haft is undecorated. It is attributed to the Assiniboin. $\mathrm{H}: 6 \frac{1}{2}^{\prime \prime} \mathrm{W}: \mathrm{I} \frac{1}{8}{ }^{\prime \prime} \mathrm{L}: 20 \frac{1}{4}^{\prime \prime}$

MAI/HF : II $/ 8046$

285. Spontoon pipe tomahawk with pick blade, (ca. I860-I880). In this instance the blade actually seems to have been made from a pick with the bowl brazed on. The haft is plain except for file branding. Attributed to the Sioux.

$\mathrm{H}: \mathrm{IO}^{\prime \prime} \mathrm{W}: \frac{5^{\prime \prime}}{8} \mathrm{~L}: 22^{\prime \prime}$

MAI/HF : $3 / 6822$

286. Spontoon pipe tomahawk with pick blade, early Igth century. In this specimen the blade seems to have been intended for the purpose, and not converted as was the previous example. The eye is round. The bowl is octagonal, and of the low, ample proportions typical in such an early piece. It could possibly be late 18 th century, but more probably dates from I800-I820. The provenience is not known.

$\mathrm{H}: 8^{\prime \prime} \mathrm{W}: \frac{5^{\prime \prime}}{}$

MAI/HF : $22 / 7329$

287. Spontoon pipe tomahawk, (ca. I860-I880). The bowl is typical of the Plains Indian form of the period. The eye is diamond shaped with a high median ridge on the outside opposite the lateral points of the diamond, and there are crisply filed moldings where the eye joins the blade. The lobes, which have replaced the basal processes, are pierced with circular holes. The haft, which is undecorated, has a strong ridge on each side and a separate mouthpiece made of a brass cartridge case. This tomahawk belonged to Kicking Bird (Tenéangapote), a famed Kiowa war leader, who was active in Oklahoma and Texas prior to his death in I875. It was collected in 1874 by Thomas C. Battey, a trader at Fort Sill, Oklahoma.

$\mathrm{H}: \mathrm{II}_{4}^{1^{\prime \prime}} \mathrm{W}: 2 \frac{3}{4}^{\prime \prime} \mathrm{L}: 27^{\frac{3}{4}}$

$\mathrm{MAI} / \mathrm{HF}: 23 / 898$

\section{Brass Heads}

288. Spontoon pipe tomahawk, (ca. I870-1890). The bowl is approaching the ungainly attenuated tulip shape sometimes encountered on specimens made after I900. The eye is diamond shaped with a median ridge on the outside. The basal processes of the blade curve downward in the reverse of the more usual manner. The haft is plain with a slight double curve reminiscent of the standard axe of the period. Attributed to the Chippewa.

$\mathrm{H}: 9^{\prime \prime} \mathrm{W}: 2^{\prime \prime} \mathrm{L}: 20 \frac{1}{2}{ }^{\prime \prime}$

MAI/HF : I9/5096 
289. Spontoon pipe tomahawk, ( $c a$. I860-I880). Here the bowl and cyc pattern of the typical Plains Indian form are readily recognizable. The brass casting is good, and the piece has been well finished. The basal processes curve downward and are well developed. Beneath them the blade is pierced with a gentle arc above a heart. The haft is file branded in a spiral pattern. For slightly over half its length it is wrapped in rawhide. Two narrow beaded bands remain around this portion; at one time there may have been a third. Attributed to the Oglala Sioux.

$\mathrm{H}: 9 \frac{11}{4}^{\prime \prime} \mathrm{W}: 2^{\prime \prime} \mathrm{L}: \mathrm{1} 6 \frac{3}{8}^{\prime \prime}$

MAI/HF : $2 \mathrm{I} / 2547$

290. Spontoon pipe tomahawk, (ca. I860-I880). An exceptionally heavy and well-made specimen. Once again the bowl and eye patterns are those typical of the Plains Indian form with the addition of knurled bands around the bowl and a sunken panel in place of the median ridge across the outside of the eye. The eye itself is oval. The haft is file branded and studded along its upper edge with brass tacks in a single line. Attributed to the Caddo in Oklahoma.

$\mathrm{H}: 9^{\frac{3}{4}}=\mathrm{W}: \mathrm{I}^{\prime \prime}{ }^{\prime \prime} \mathrm{L}: \mathrm{I} 8^{\prime \prime}$

$\mathrm{MAI} / \mathrm{HF}: 5 / 64$

291. Spontoon pipe tomahawk, (ca. I860-I880). Generally similar to No. 292 but better made and more vigorous in its design. The bowl is sevensided with cabled moldings at top and bottom. The eye is a pointed ellipse. The lobes which have taken the place of basal processes are at least pierced to carry on the effect of curved arms. The haft is wrapped for almost its entire length in brass wire. The remaining few inches are studded with brass tacks, and two buckskin thongs with fringe are looped around. Attributed to the Kainah Blackfoot.

$\mathrm{H}: 8^{\prime \prime} \mathrm{W}: 2^{\prime \prime} \mathrm{L}: 19 \frac{5}{8}^{\prime \prime}$

$\mathrm{MAI} / \mathrm{HF}: 6979$

292. Spontoon pipe tomahawk, (ca. I870-1890). The general characteristics of the Plains Indian form can be recognized in the bowl and eye area, but poorly executed and decadent in feeling. The eye is actually a teardrop. The basal processes have given way to lobes. The haft is plain except for one feather tied with a rawhide thong to a hole in the lower edge of the haft. Attributed to the Santee Sioux.

$\mathrm{H}: 9^{\frac{3}{4}}{ }^{\prime \prime} \mathrm{W}: 2 \frac{1^{\prime \prime}}{2} \mathrm{~L}: 2 \mathrm{I}^{\frac{7}{8}}{ }^{\prime \prime}$

MAI/HF : $20 / 4908$

293. Spontoon pipe tomahawk, (ca. I880-1910). A very large, late form which even more strikingly resembles the spontoon than most of those made in years when the spontoon was still used. The bowl is of the typical Plains pattern. The eye is diamond shaped. The basal processes are broad and curve down only slightly, while the blade continues to a blunt point. Incised scrolling decoration is cast into it. Provenience unknown.

$\mathrm{H}:$ II $\frac{1}{8}{ }^{\prime \prime} \mathrm{W}: 2^{\prime \prime}$

William O. Sweet collection

\section{Pewter Heads}

294. Recent spontoon pipe tomahawk; an early 2oth century specimen. The head is cast with a flat blade one-quarter inch thick. It is inlaid with catlinite and slate. The eye itself is oval, but the outside is rectangular. The haft is made from a board and is studded with brass tacks. Attributed to the Sisseton Sioux.

$\mathrm{H}: \mathrm{II}_{\frac{1}{2}}{ }^{\prime \prime} \mathrm{W}: \mathrm{I}^{\frac{7}{8}}{ }^{\prime \prime} \mathrm{L}: 26 \frac{1}{4}^{\prime \prime}$

MAI/HF : I4/29I4 
295. Spontoon pipe tomahawk, (ca. 1870). A crude casting with an exceptionally tall bowl foreshadowing the later tulip shape. The eye is a pointed ellipse with a median ridge on the outside. The pointed base molding of the bowl terminates right at the ridge, as is typical of the most usual Plains Indian form. The basal processes are long and thin and curl sharply around on themselves; below them the blade is kite shaped with a slight median ridge. In all specimens of this form that have been examined, the haft is cut down to enter the eye so that this unusual procedure is to be expected. The haft is file branded and studded with brass tacks in bands and on the fore end. This specimen was collected in 1870 , at which time it must have been almost new. Attributed to the Miami.

$\mathrm{H}: \mathrm{II}^{\prime \prime} \mathrm{W}: 2 \frac{3{ }^{\prime \prime}}{} \mathrm{L}^{\prime}: 22 \frac{1}{2}^{\prime \prime}$

$\mathrm{MAI} / \mathrm{HF}: \mathrm{I} 4 / 5984$

296. Spontoon pipe tomahawk, (ca. I890-I9Io). A late casting with a flat, kite-shaped blade three-sixteenths of an inch thick. The eye is oval. The bowl is poorly formed. There is a cloth gasket around the haft inside the eye. The haft is straight and plain. Attributed to the Winnebago.

$\mathrm{H}: 9 \frac{3}{8}^{\prime \prime} \mathrm{W}: 2 \frac{5}{8}^{\prime \prime} \mathrm{L}: 23^{\prime \prime}$

MAI/HF: $20 / 4917$

297. Spontoon pipe tomahawk, (ca. I880-1900). The eye is rectangular. The neckless bowl flares towards the top with straight sides. Brass tacks have been driven into the center of the diamond-shaped blade from both sides, leaving the heads to form bosses. There is also a faint scratch engraving of a buffalo head on the reverse side. The haft is wrapped with strips of cloth and two beaded bands, and there is one band of brass tacks. Attributed to the Santee Sioux.

$\mathrm{H}: 6 \frac{1}{2}^{\prime \prime} \mathrm{W}: \mathrm{I}_{\frac{3}{4}}^{\prime \prime} \mathrm{L}: \mathrm{I} 7 \frac{1}{4}^{\prime \prime}$

$\mathrm{MAI} / \mathrm{HF}: 20 / 4569$

298. Spontoon pipe tomahawk, (ca. I890-I9Io). The wide bowl with top and bottom moldings is better formed than most in this period. The eye is teardrop, though there is a median ridge on the outside. The blade has file nicks for decoration along the top edges, and there are geometrical designs in scratch engraving. The haft narrows to enter the eye. A cloth gasket is wrapped around it. The eye is diamond shaped in section with serrated top and bottom edges. Running chevrons are cut into the upper surfaces, and a short line of brass tacks has been driven in near the head. Attributed to the Chippewa.

$\mathrm{H}: 6^{\prime \prime} \mathrm{W}: 2 \frac{1{ }^{\prime \prime}}{} \mathrm{L}: 16 \frac{1}{4}^{\prime \prime}$

MAI/HF : 20/9755

\section{Stone Heads}

299. Spontoon pipe tomahawk, (ca. I860-1880). This unique example is finely carved of black slate, perfectly copying the metal object of the period. It is inlaid with pewter and catlinite in designs comprising a four-pointed star, a square enclosing a cross, a bird, and a diamond. The eye is oval. Attributed to the Nez Percé.

$\mathrm{H}: 6 \frac{7^{\prime \prime}}{8} \mathrm{~W}: \mathrm{I}^{\frac{1}{2}}{ }^{\prime \prime}$

MAI/HF : I9/6655 


\section{TOMAHAIKS AND HATCHETS USED BY WHITE MEN}

300. Spiked tomahawk used by a colonist ( $\mathrm{ca}$. I750-I775). It is forged in the manner usual for such axes. The eye is oval and there are well-developed ears. The spike is rectangular in section, and its point has been flattened through striking some hard object. The haft is original. Found in an old house in Brattleboro, Vermont.

$\mathrm{H}: 5^{\frac{1}{4}}{ }^{\prime \prime} \mathrm{W}: 2^{\prime \prime} \mathrm{L}: \mathrm{I} 2 \frac{1}{4}^{\prime \prime}$

Ben F. Hubbell collection

301. Pipe tomahawk, (ca. I776-I78I). This specimen is a most interesting document. Undoubtedly made for use by a white colonist during the American Revolution or very shortly thereafter, it is one more indication of the fact that pipe tomahawks were used by whites as well as by Indians. The pipe bowl is now missing. The eye is round. The poll is flat with a hole where the pipe bowl was riveted and welded in place. The moldings above and below the eye are well developed, and the blade is gracefully shaped with a chamfer along the rear line. There is a steel edge. But of paramount interest are the inscriptions inlaid in brass. On the obverse side appears “I·G / AME / RICA / LIBE / RTI I 776." The date may possibly be I775, but 1776 seems more likely in view of the fact that liberty did not become a popular cause until the signing of the Declaration of Independence. A complete transliteration would be In God American Liberty I776. The date need not be that of the manufacture of the hatchet, but its form and the style of the inscription would indicate that it was made during the war. The haft is modern. Collected in Massachusetts.

$\mathrm{H}: 5 \frac{3}{8}^{\prime \prime} \mathrm{W}: 2 \frac{1}{8}^{\prime \prime} \mathrm{L}: \mathrm{I} 3 \frac{1}{8}^{\prime \prime}$

MAI/HF: $22 / 7239$

302. Tomahawk with hammer poll bearing US mark, late I8th century. Compare this example with No. 98, which appears identical except that in this instance the hammer is octagonal in section and heavily mushroomed from use. Once again the cartouche bearing the maker's name is illegible, but the U. S. mark is strong and clear. In all probability this axe was issued to troops during or shortly after the Revolution. Provenience unknown.

$\mathrm{H}: 5 \frac{1^{\prime \prime}}{}{ }^{\prime \prime} \mathrm{W}: 2^{\prime \prime}$

Herb Glass collection

303. Superbly made pipe tomahawk (ca. I80o-I8I5). This is probably the finest head encountered during the course of the present study. The bowl is finely faceted with well-developed moldings. There is a steel edge, and the whole of the head is enhanced with engraving and inlays of gold and silver. In addition, the background appears to have been russeted to give greater contrast to the inlays. On the obverse side these decorations include a deer fleeing from a hunter and his dog as the hunter aims a flintlock. The background is a stylized tree with a distelfink, a typically Pennsylvania Dutch bird, perched above a cartouche bearing the name "F. HOFF." Hoff was a blacksmith in Lancaster County, Pennsylvania, ca. I80o-I 8I 5. Below the scene, along the edge, is inscribed "American Horse" in script. The reverse side bears an American eagle with shield and a trophy of arms and flags. Although the general form of the blade is of a type which would normally be dated slightly later, the style of decoration, plus the name of the maker seem to indicate the earlier period. Exact dimensions are not available. Provenience is unknown. Although there was a famous Indian chief named American Horse (I825?-I875), he was not connected with this specimen.

Clem Caldwell collection 
304. Unique tomahawk with eagle poll, (ca. I810-1830). The interesting eagle poll on this specimen is a fine forging in a graceful adaptation of the older spiked form. The eye is oval with serrated edges around the outside. Across the center is engraved the name "JAs McTEAR", apparently the owner. The blade is simple with relatively straight lines and only a slight flare to the rear. The provenience is not known.

Henry Ford Museum: 62.32

305. Tomahawk with hammer poll presented to Davy Crockett; an interesting specimen of highly polished steel. The hammer flares slightly toward the top and is octagonal in section. The eye is a pointed ellipse, but the outside has been forged to present a flat circular surface on each side. The blade flares symmetrically in concave arcs. Across the reverse side is engraved the name Crockett in script, and on the obverse Go Ahead. The haft is smooth, flaring slightly toward the mouth end where it diminishes suddenly and enters a carved ivory mouthpiece with a brass ferrule at the joint. This hatchet was presented to Davy Crockett by "The Young Men of Philadelphia" in 1834 or 1835 .

$\mathrm{H}: 5 \frac{7^{\prime \prime}}{8} \mathrm{~W}: 4 \frac{5}{8}{ }^{\prime \prime} \mathrm{L}: \mathrm{I} 6 \frac{5}{8}{ }^{\prime \prime}$

Smithsonian Institution USNM : 359628

306. U. S. Army hatchet, Igth century. Following in the tradition of the fully developed American hatchet of the late I8th century illustrated as No. 40, hand axes of this form were issued by the Army throughout almost the entire I9th century. They seem to have been standard by the time of the War of I8I2 and continued in use until the ears disappeared about the end of the century. The present specimen was excavated on the Civil War battlefield of Brandy Station, Virginia. The eye is a flat ellipse, pointed slightly at its lower end. The poll is thick and counter-balances the blade and has been mushroomed slightly from pounding. There is a steel edge.

$\mathrm{H}: 4 \frac{5}{8}^{\prime \prime} \mathrm{W}: 2 \frac{3}{4}^{\prime \prime}$

Author's collection

307. U. S. Army hatchet, Civil War period. In addition to the form of hatchet commonly issued by the Army and described above, Civil War battlefields also yield a number of shingler's hatchets of this form. The hammer is rectangular in section, but with chamfered corners so that it is almost octagonal. The eye is a long slender teardrop, almost a pointed ellipse. There is a steel edge, and a nail-pulling slot is cut in the rear line.

$\mathrm{H}: 6 \frac{1}{4}^{\prime \prime} \mathrm{W}: 3 \frac{1 \frac{1}{2}^{\prime \prime}}{}$

Author's collection

308. British boarding axe, (ca. I750-1850). The head is forged from two pieces of iron plus a steel edge in the usual manner for a spiked axe. Interesting additions in this instance, however, are the two straps running along the haft and fastened by two transverse rivets. The eye is round and tapers slightly from back to front. On the obverse side of the blade appear a cartouche bearing an illegible maker's name, the broad arrow signifying government ownership, and two broad arrows struck point to point indicating that the piece has been sold. The haft has been shortened an indeterminate amount. (Of eight identical specimens examined during this study, all have been cut off at approximately the same point.) Both head and haft are painted black. 
309. Boarding axe, probably British, (ca. I800-I850). This specimen bears many similarities to the preceding one in the method of forging and general shape of the blade. Differences include the narrower, slightly curved spike and the two notches in the rear line of the blade. It was excavated in San Juan County, Washington, and undoubtedly came from one of the naval vessels which frequented the area.

$\mathrm{H}: 7^{\frac{1}{4}}{ }^{\prime \prime} \mathrm{W}: 2 \frac{1}{2}^{\prime \prime}$

MAI/HF : 4/54I2

310. American boarding axe, (ca. I800-I850). The present specimen was found in an Indian burial in New Jersey. No marks are visible, but identical specimens bearing U. S. marks have been found. The eye is round and tapers to the rear in the normal manner for picks and tomahawks. There are no straps. Characteristic of this particular form is the right-angle turn of the rear line of the blade with two notches along the top.

$\mathrm{H}: \mathrm{II}^{\prime \prime}{ }^{\prime \prime} \mathrm{W}: 3 \frac{3^{\prime \prime}}{8}$

MAI/HF : IO/4993

311. American boarding axe, (ca. I800-I850). Closely related to the previous specimen, this axe is slightly more sophisticated. The spike is rectangular in section and at one time had a point with chamfered edges which has since been cut off. The eye is round and tapers to the rear. The blade has two notches in the rear line. The straps are separate from the head, passing through the eye and forming a convex split cover for the fore end. On the reverse side of the blade is stamped "U. S. / N. Y. W. [Navy Yard, Washington] J. T. [the inspector's initials]." The obverse side bears a much later stamping "ORD'CE [Ordnance] / N. Y. N. Y. [Navy Yard, New York] / I 852." This second inscription would indicate that it was reinspected and issued from New York at that date. The head and straps are painted black. The haft is round with a flattened ball at the butt. Other axes of this pattern are known with slightly different hafts.

$\mathrm{H}: 9^{\frac{1}{2}}{ }^{\prime \prime} \mathrm{W}: 2 \frac{3}{4}^{\prime \prime} \mathrm{L}: 24^{\prime \prime}$

Author's collection

312. French boarding axe, model I833. An exceptionally massive specimen with heavy spike, diamond shaped in cross section. The eye is rectangular, and the straps which lie along the top and bottom of the haft pass through it and are headed on the fore end. They are fastened together by two vertical rivets which pass through the haft. On the reverse side is a belt hook which also passes through the eye and is held in place by a screw directly behind the head. The blade flares symmetrically in concave arcs and is stamped on both sides with an anchor. Both head and haft are painted black. Although this axe is French, many specimens are found in America, and the present specimen was actually purchased as Civil War surplus at the Boston Navy Yard late in the last century, lending credence to the fact that numbers of them were manufactured for use during that war.

$\mathrm{H}: 9^{\prime \prime} \mathrm{W}: 4 \frac{7}{8}^{\prime \prime} \mathrm{L}: 2 \mathrm{I}^{\prime \prime}{ }^{\prime \prime}$

Author's collection

313. American boarding axe. This model is a heavy shingler's hatchet with straps along the haft. Its exact date of adoption is not known, but it was used during the Civil War and thereafter as long as boarding axes were issued. The head is usually made of cast steel with a hammer which flares slightly toward the top and is rectangular in section with rounded corners. The straps are fastened by two transverse rivets, and the blade has two 
rectangular slots in the rear line. Some specimens are stamped "U. S. NAVY" on the blade. The present specimen is stamped "WARRANTED / CAST STEEL" in two vertical lines on the reverse of the hammer.

$\mathrm{H}: 6 \frac{7}{8}^{\prime \prime} \mathrm{W}: 4 \frac{1}{8}^{\prime \prime} \mathrm{L}: \mathrm{I} 7 \frac{1}{2}^{\prime \prime}$

Author's collection

314. Frog for Civil War boarding axe. Made of black harness leather with a loop for the belt and a strap to button over the top of the axe, these frogs provided the means for carrying the boarding axe into action. The button for the strap is a pointed stud of brass, and there is a gusset at the back of the pocket to allow for the flat end of the hammer. On the front portion of the pocket is stamped a pointed ellipse bearing the legend "NAVY YARD / N. Y. / I865" plus two anchors. The period following the " $Y$ " in the second line is actually a tiny five-pointed star. Frogs for post-Civil War boarding axes were generally similar but lacked the gusset at the rear of the pocket. The brass stud also was round headed instead of pointed, and the stamp consisted of a generally rectangular cartouche with the words "U. S. N. Y./ BOSTON" or a similar Navy Yard without date or anchors.

$\mathrm{H}: 6 \frac{1^{\prime \prime}}{2} \mathrm{~W}: 8^{\prime \prime}$

Author's collection 
PHOTOGRAPHS OF TOMAHAWKS 


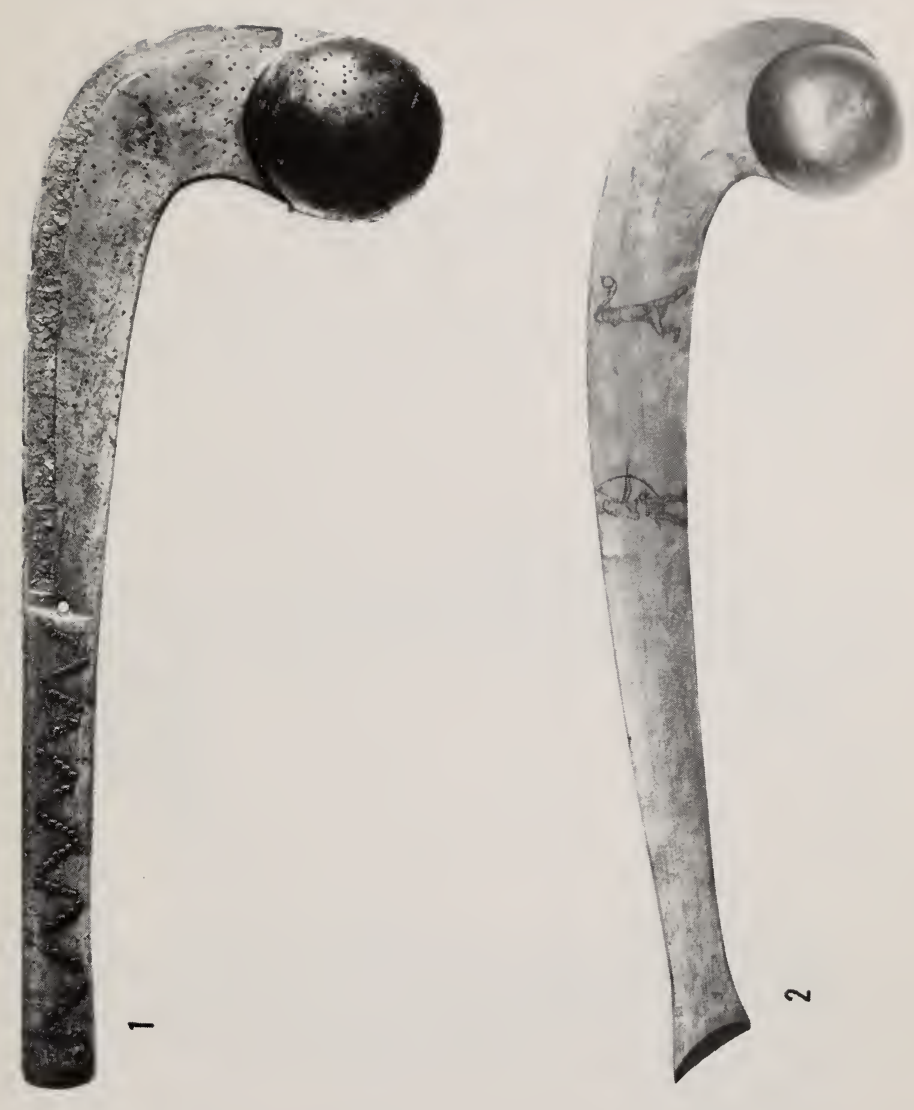

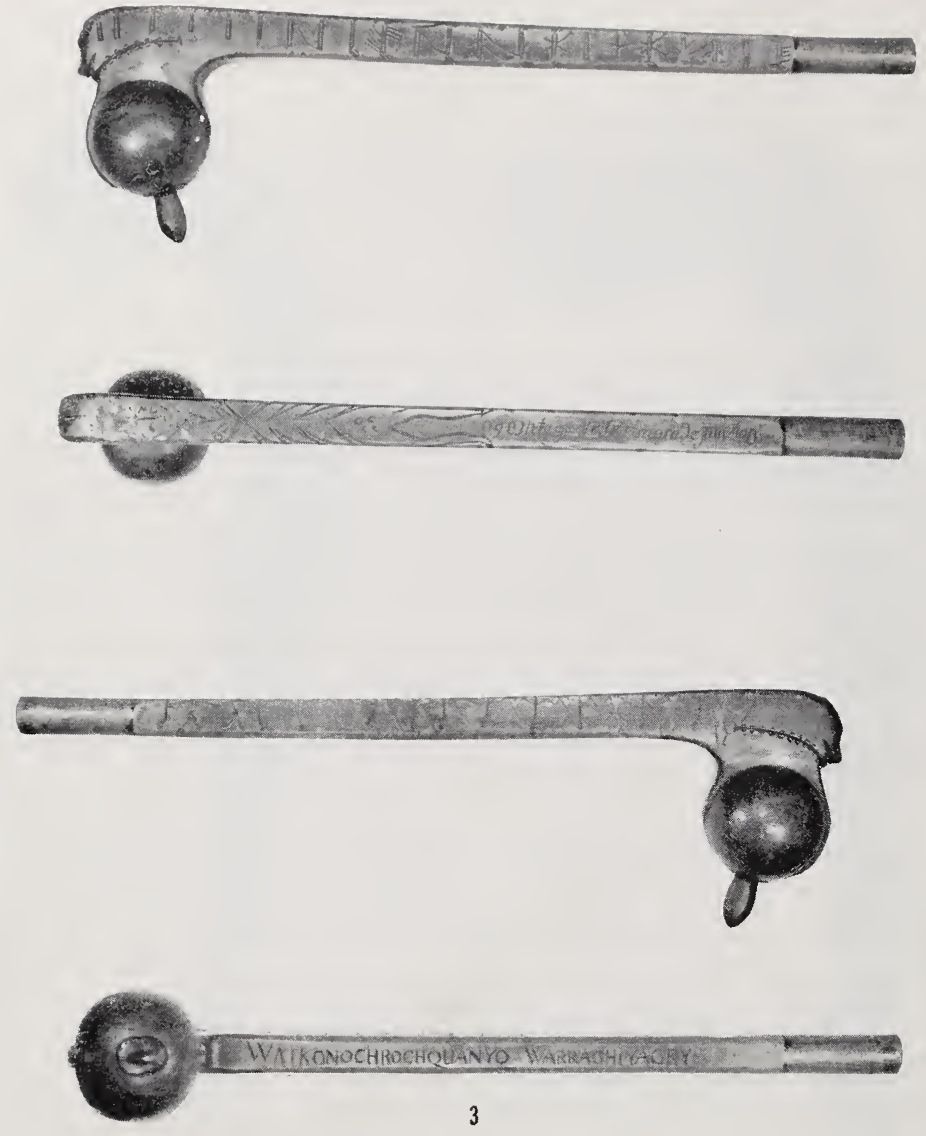

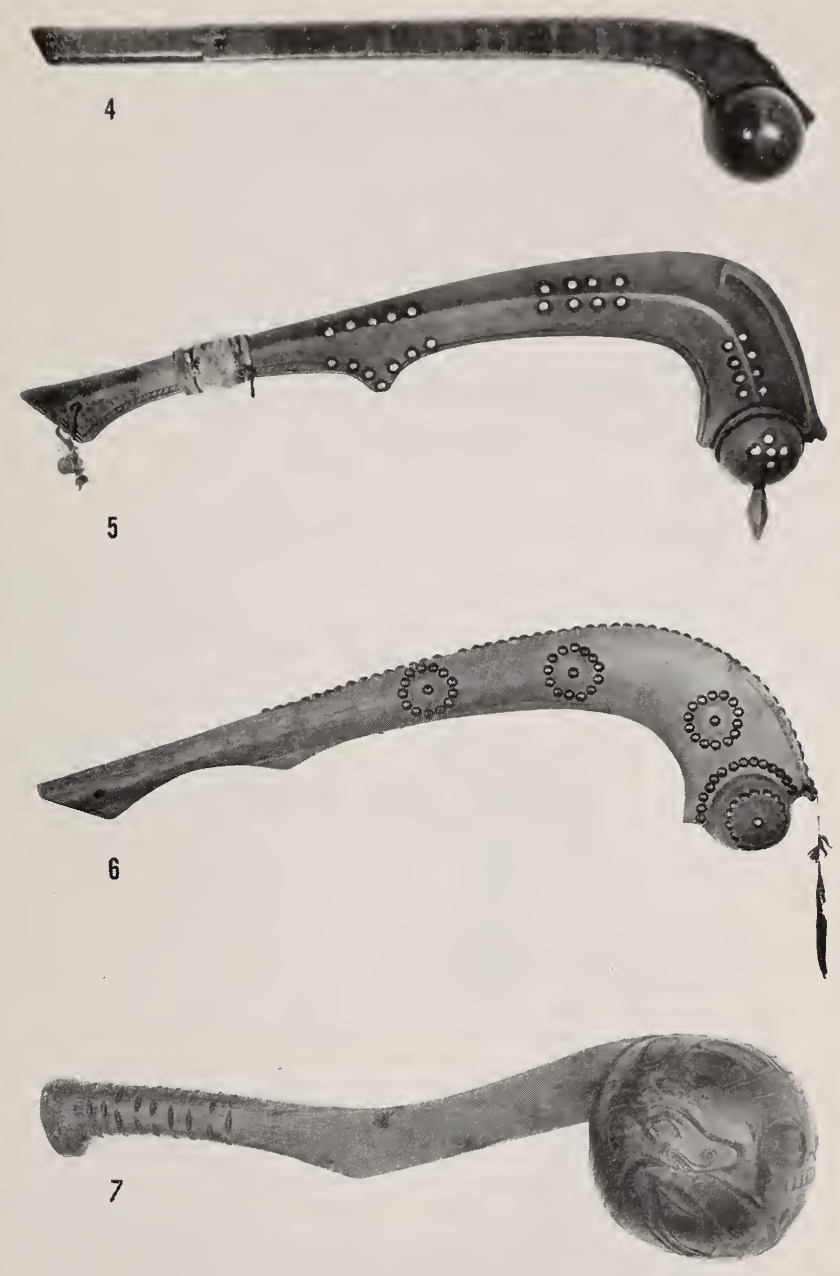

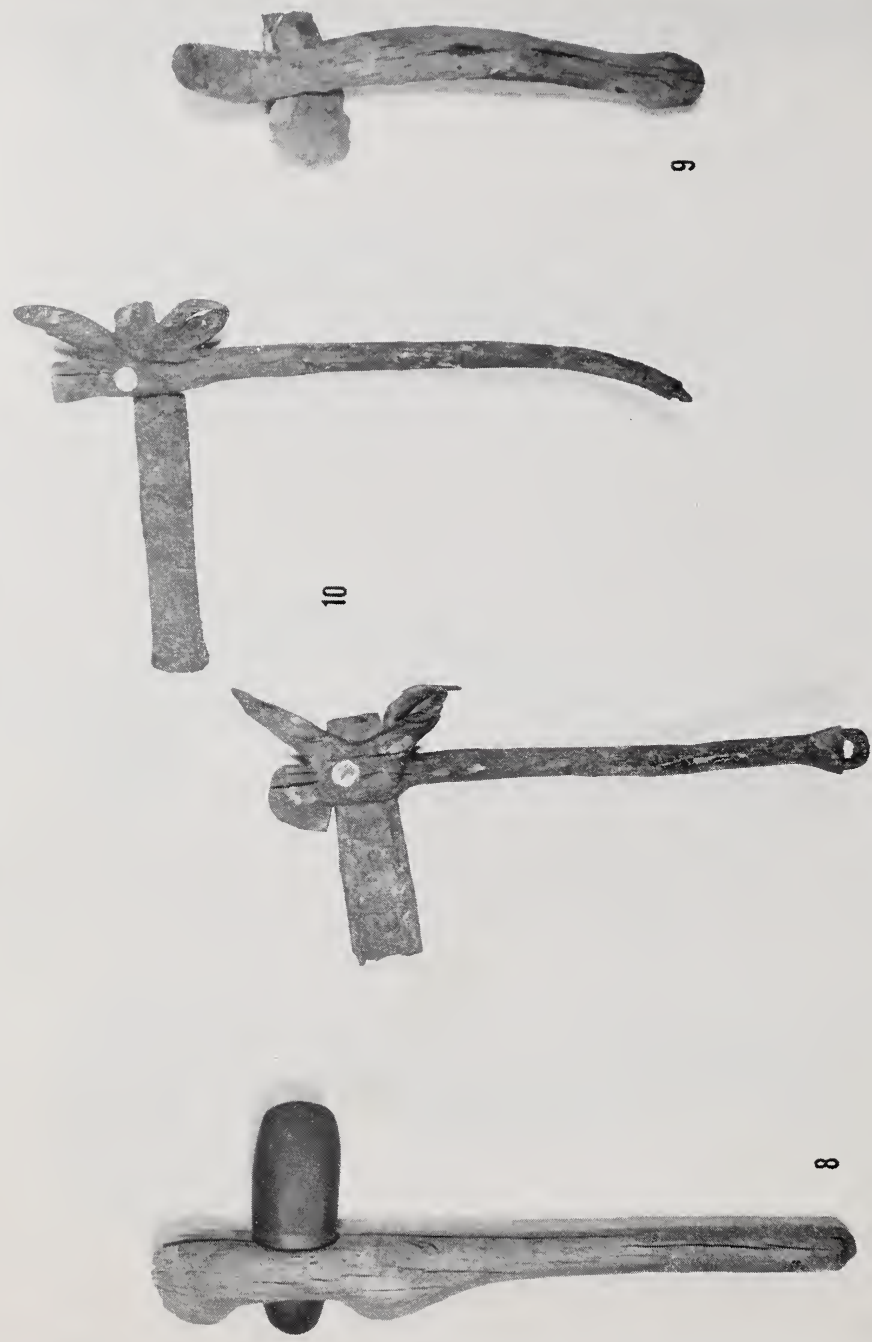

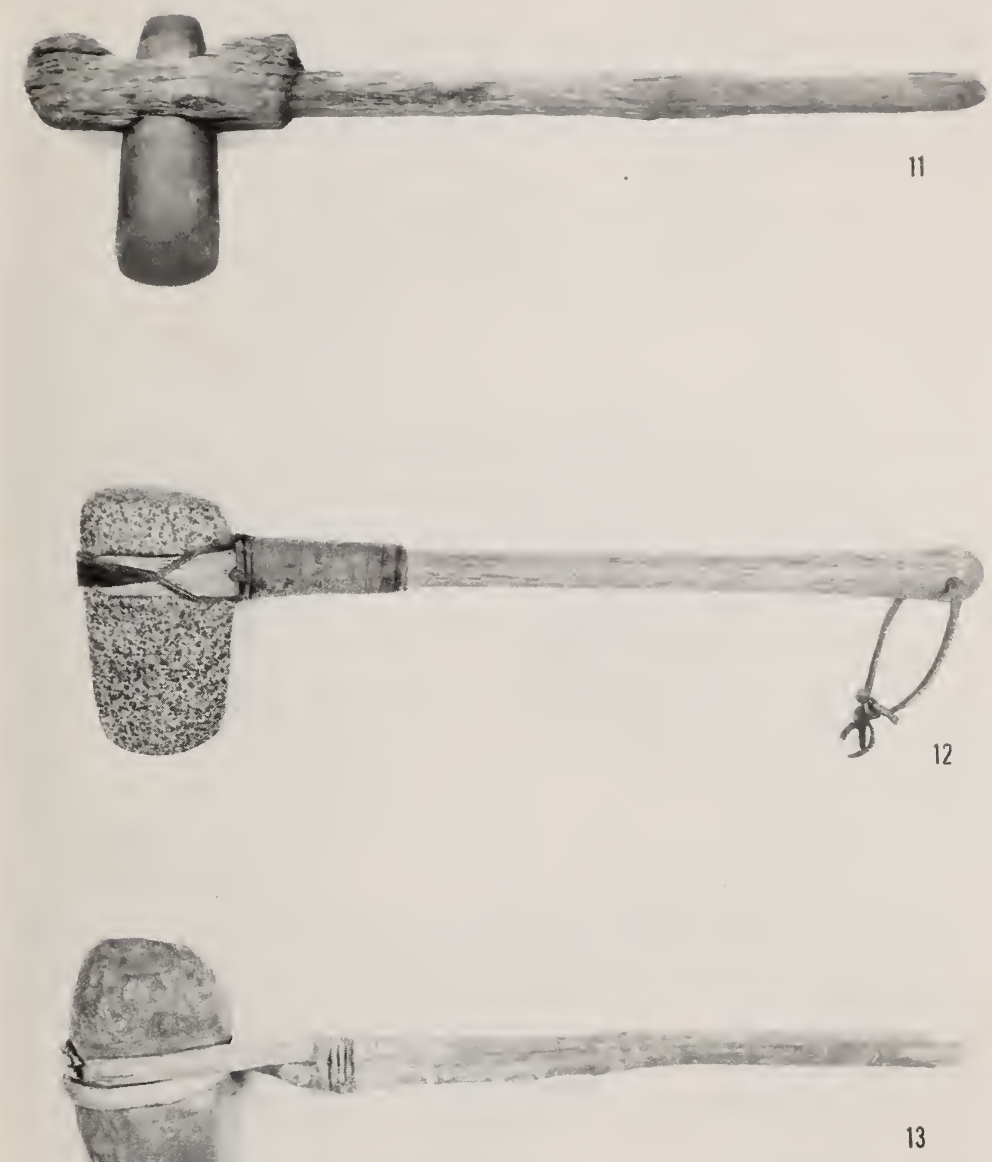

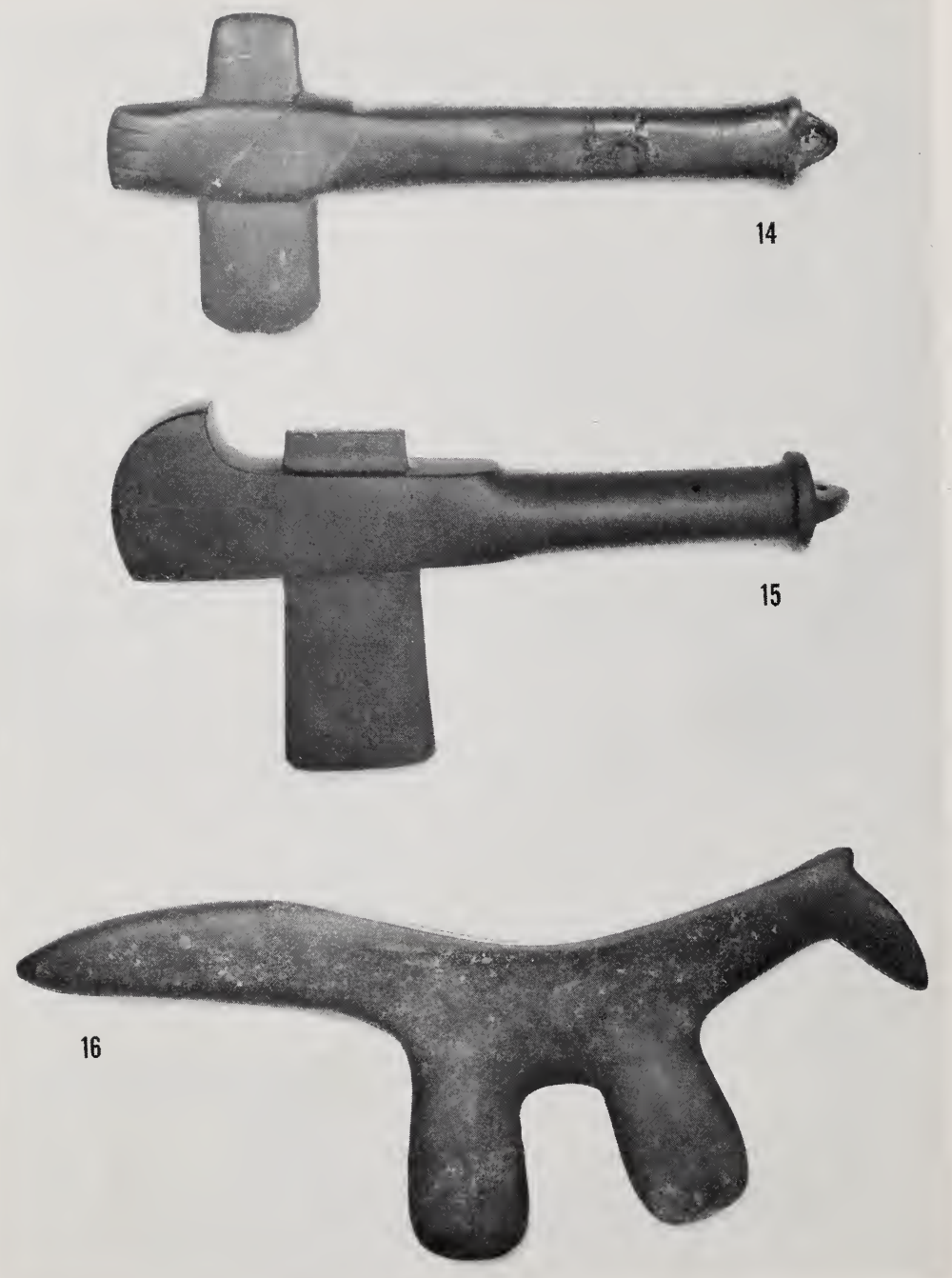


$$
+7
$$



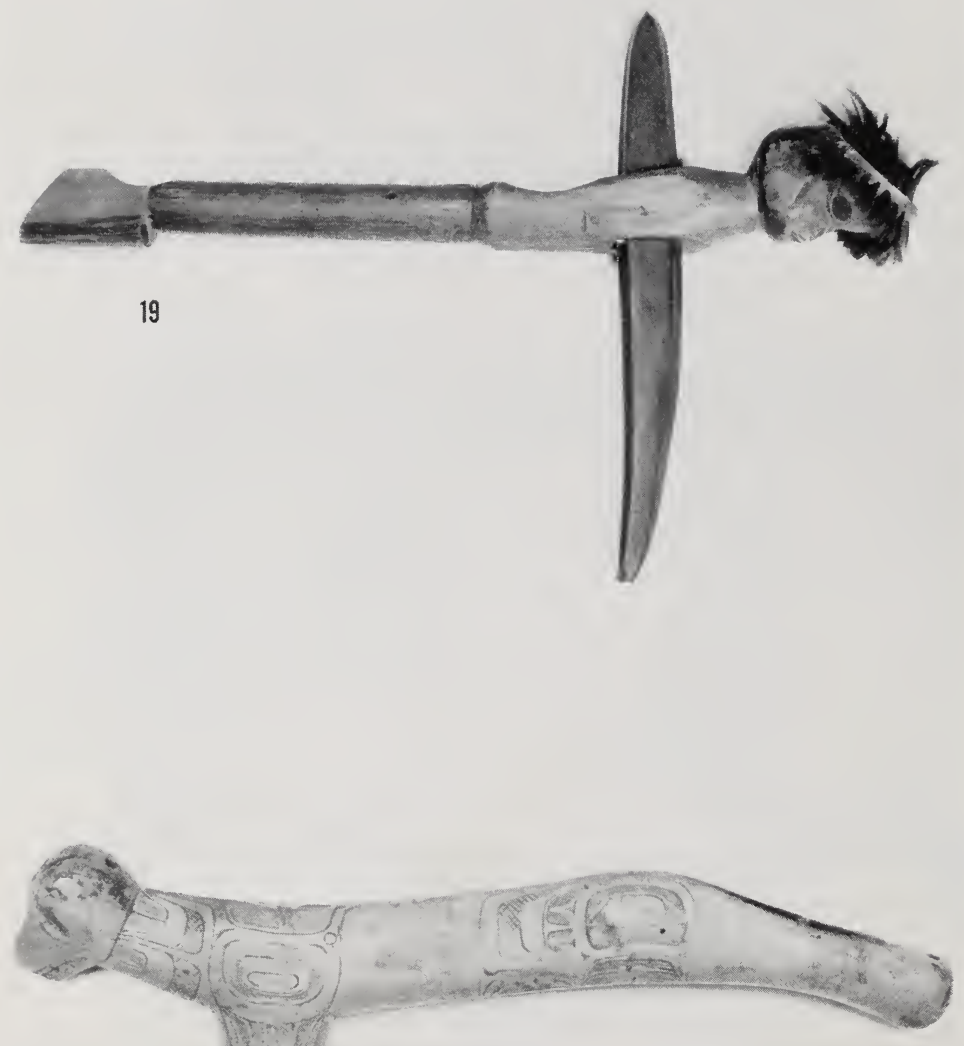


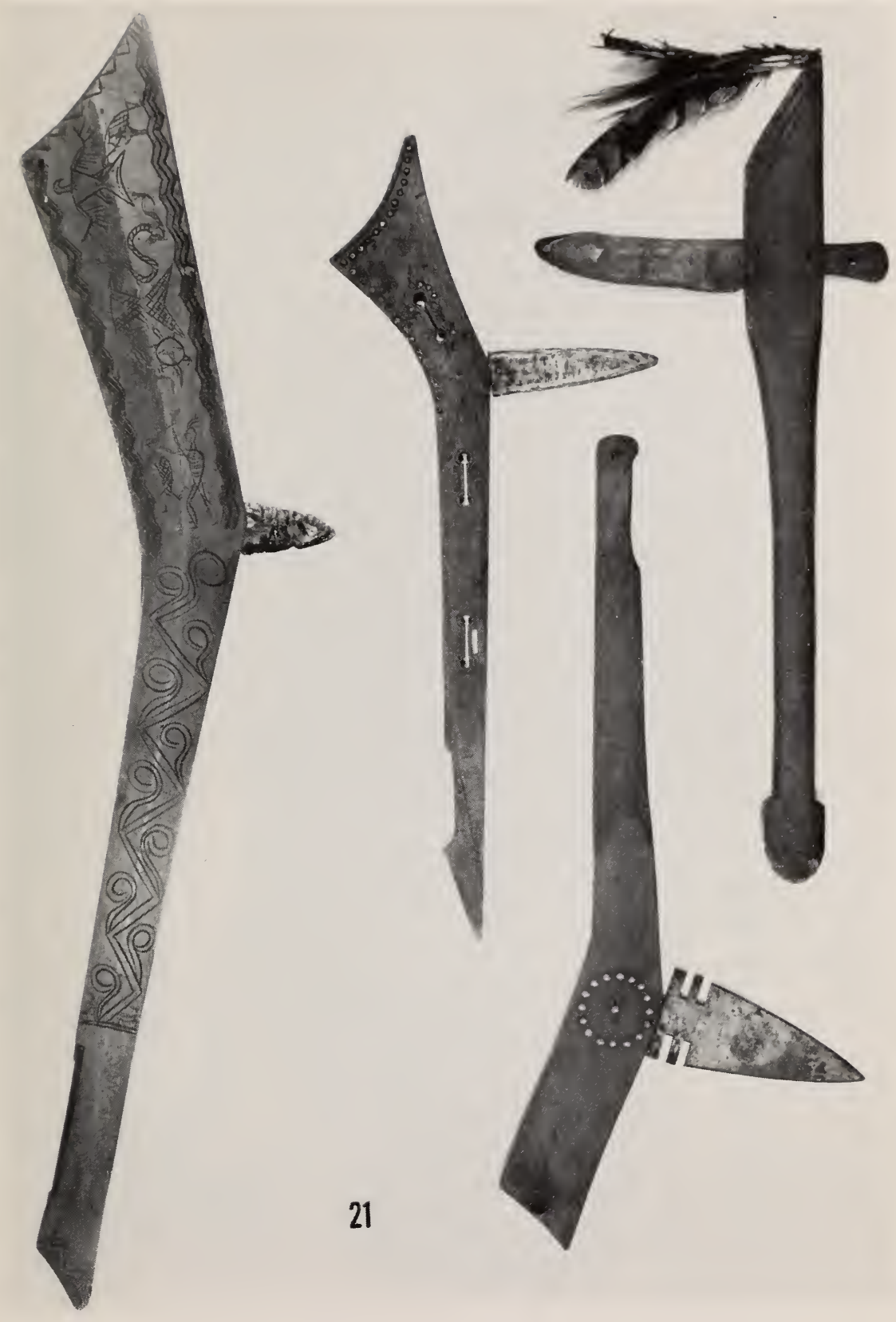



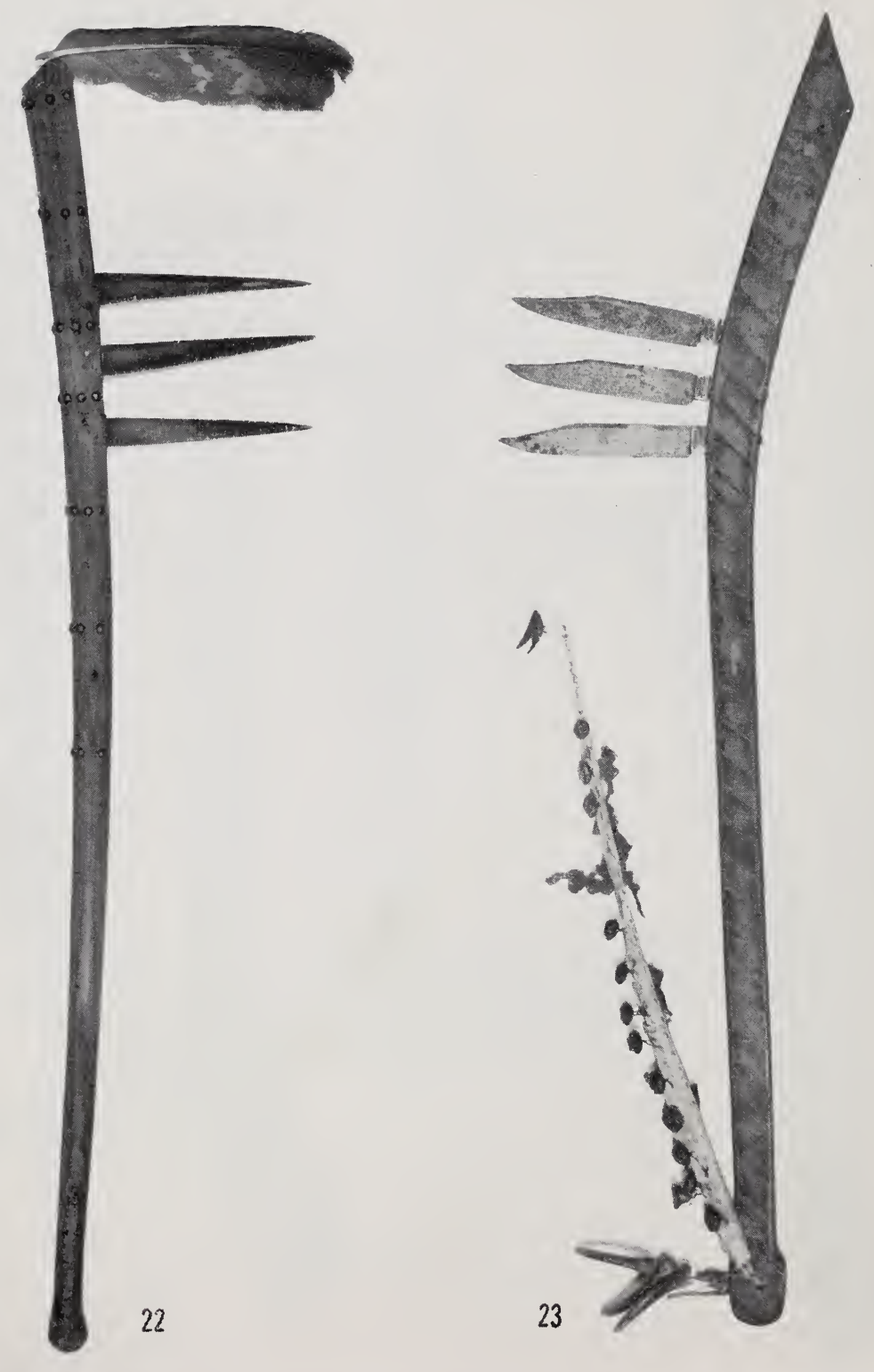


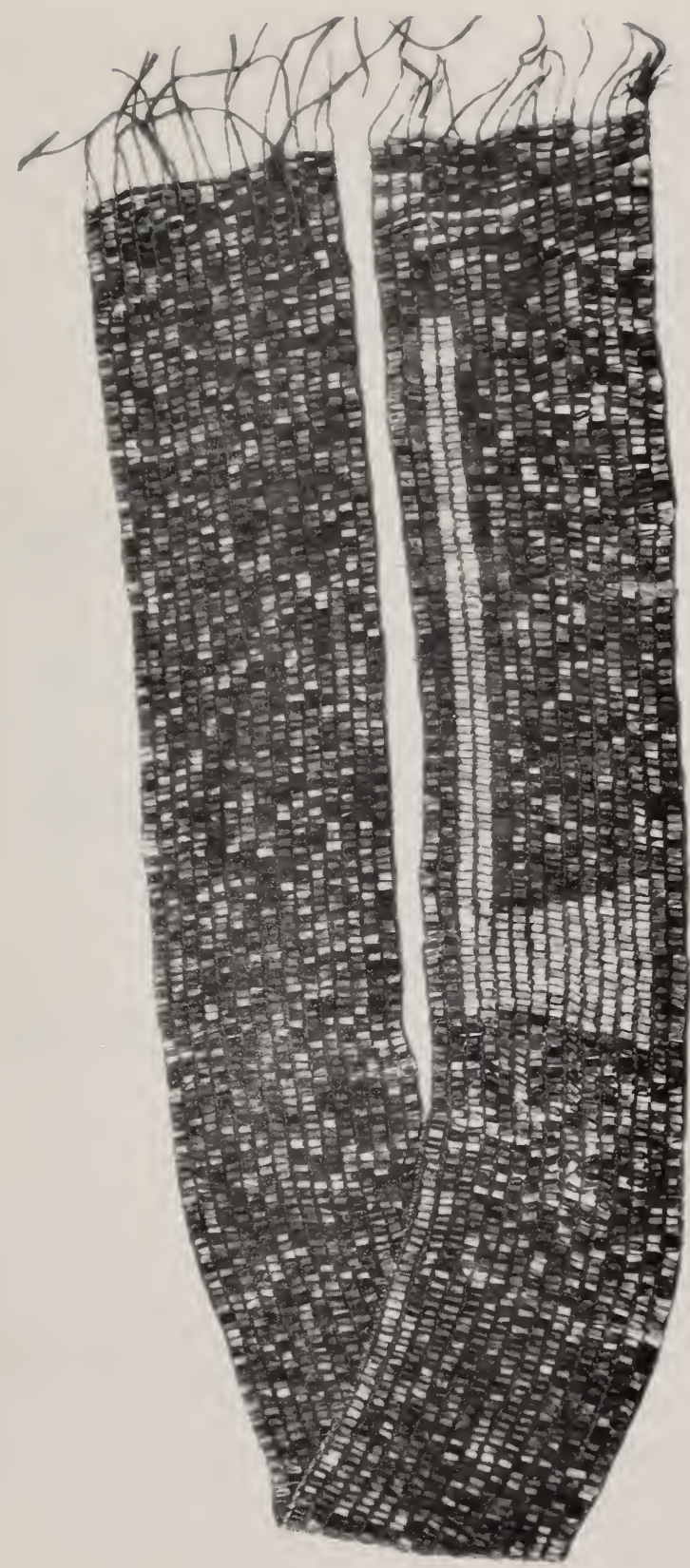



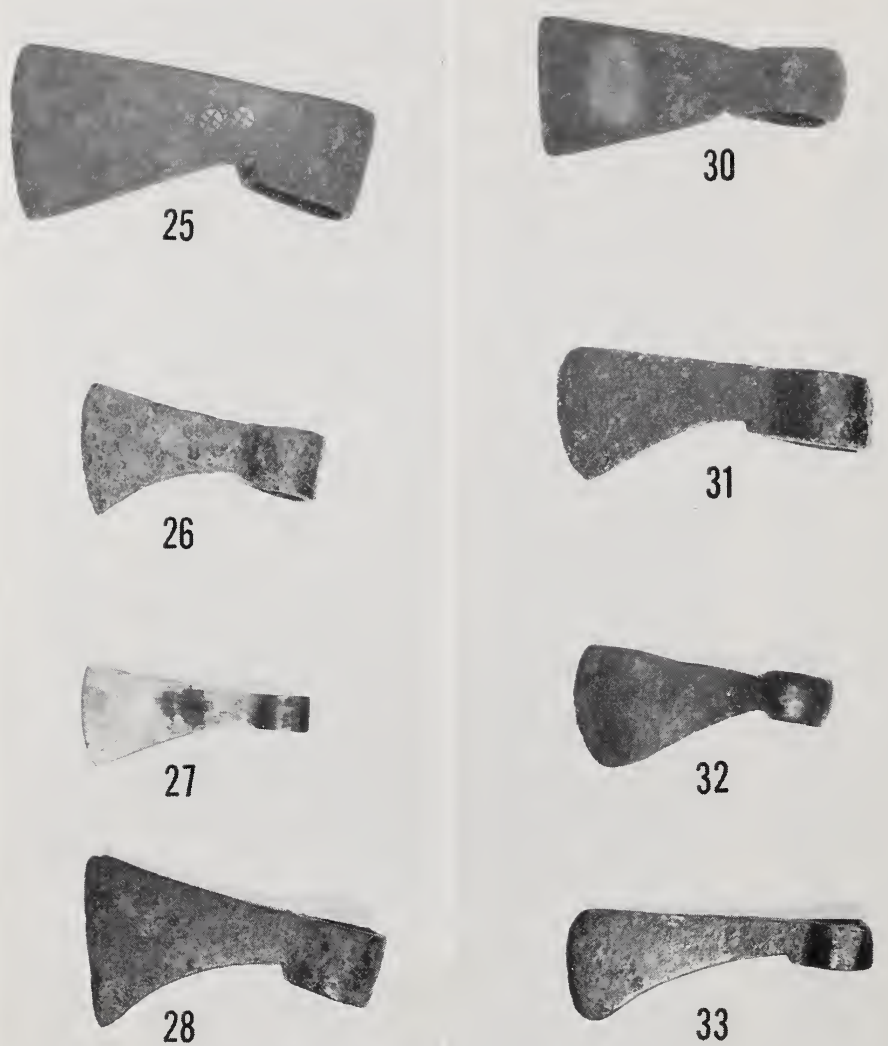

29

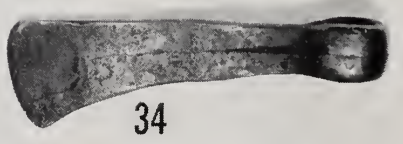




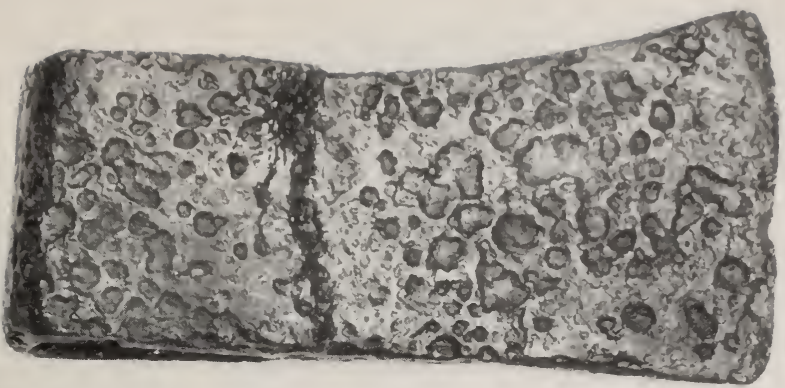

m

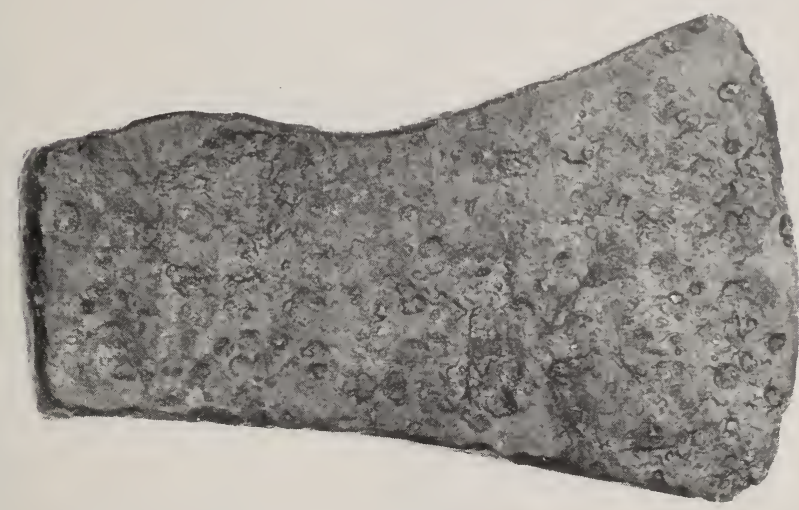

c్

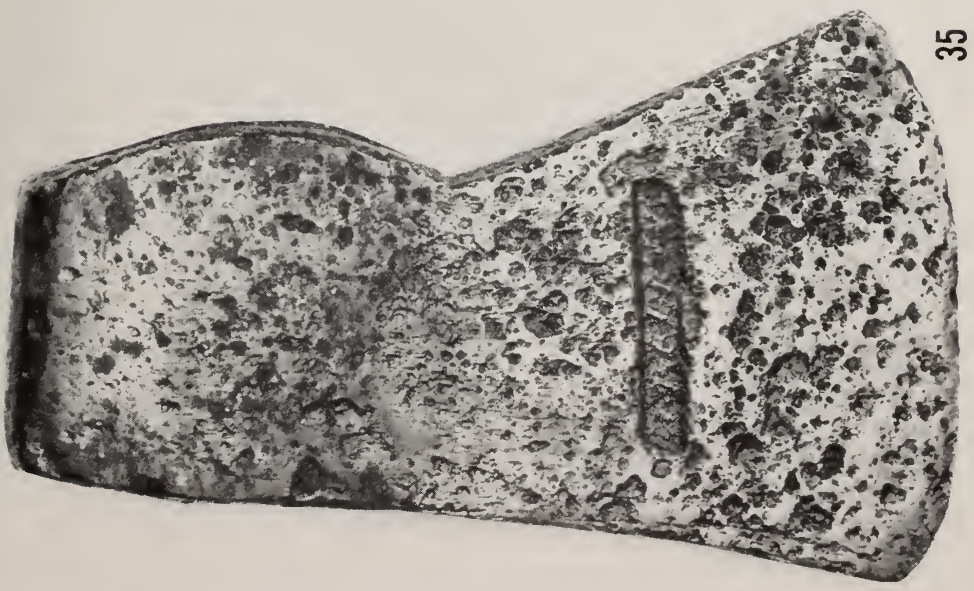



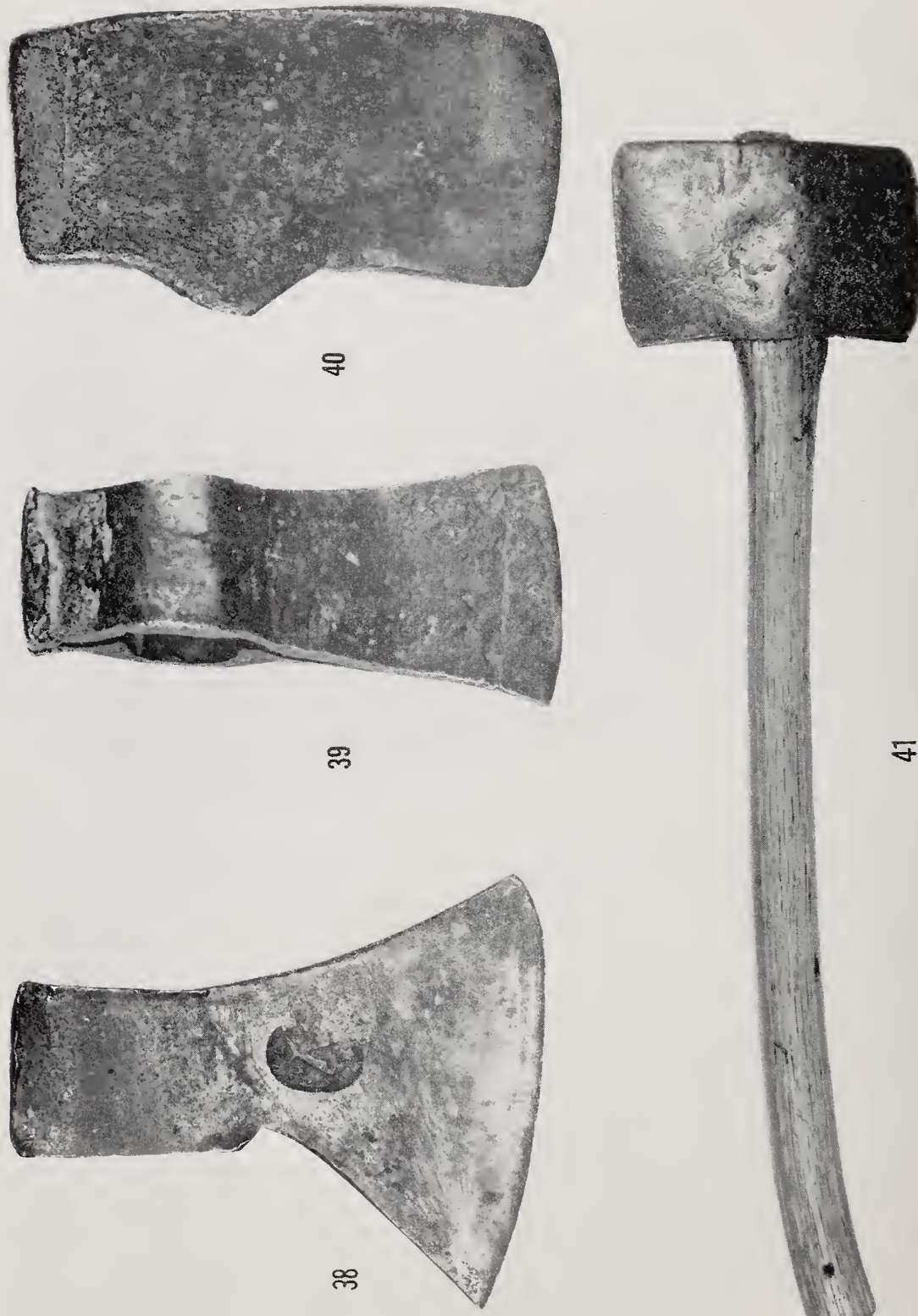


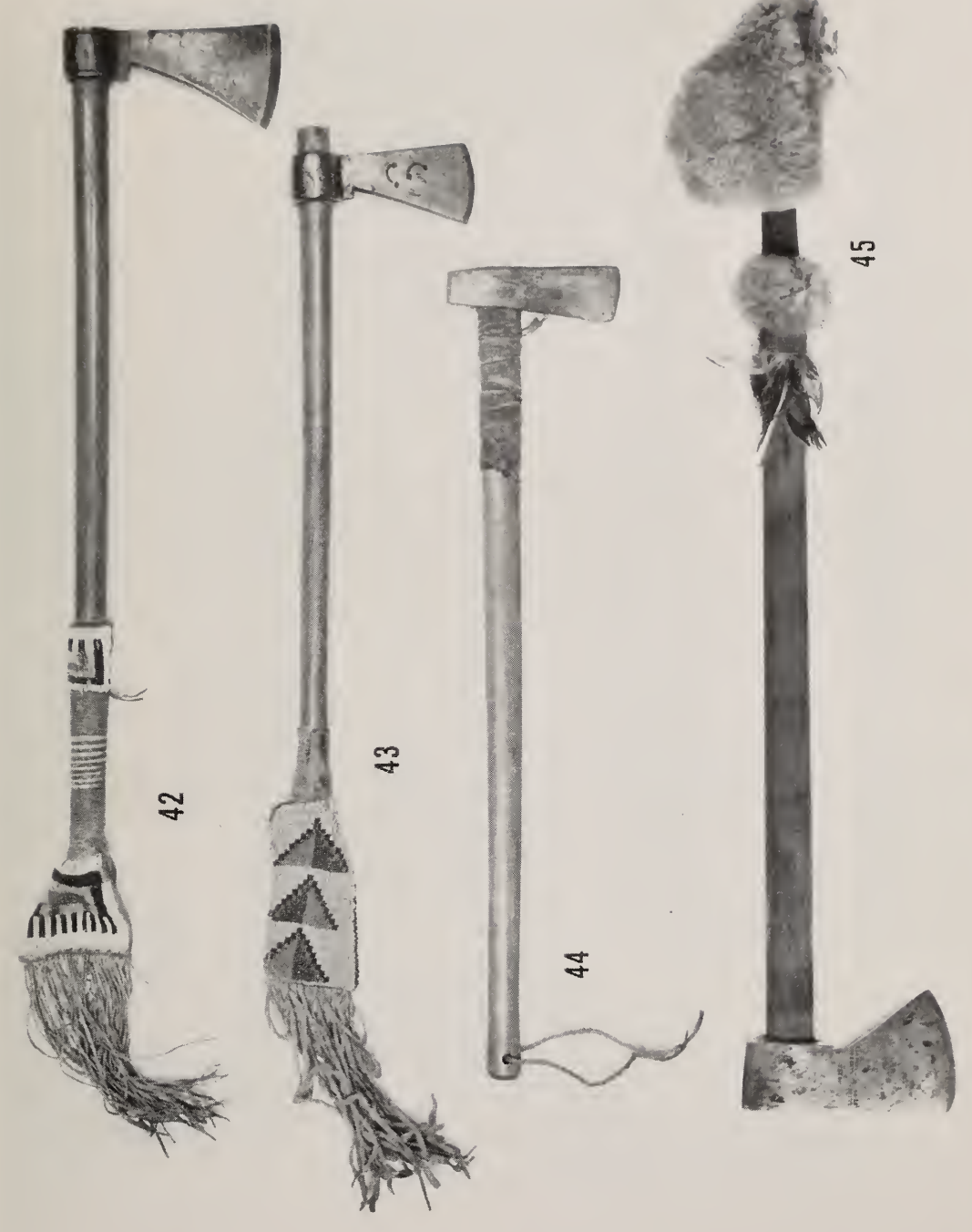




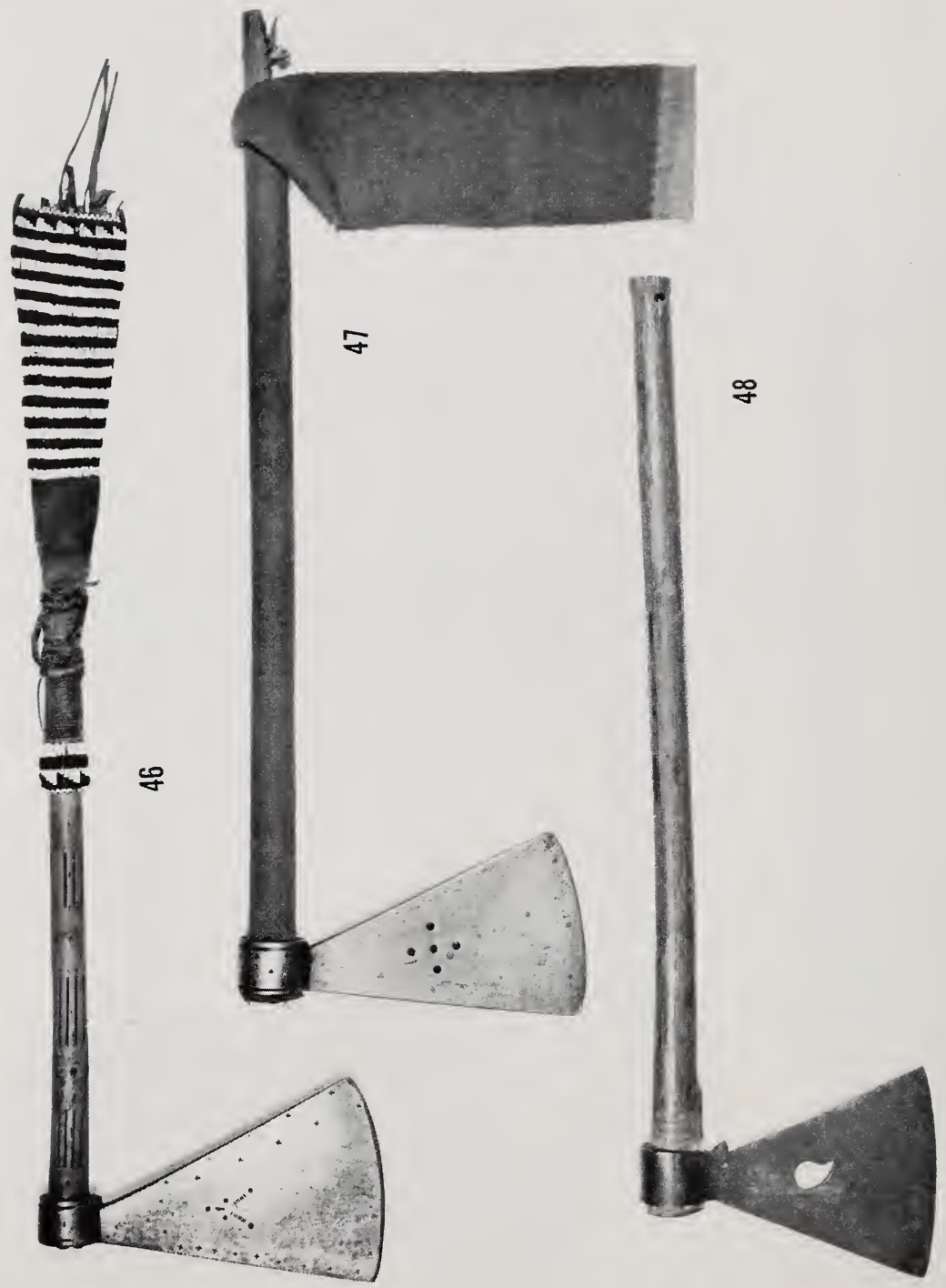




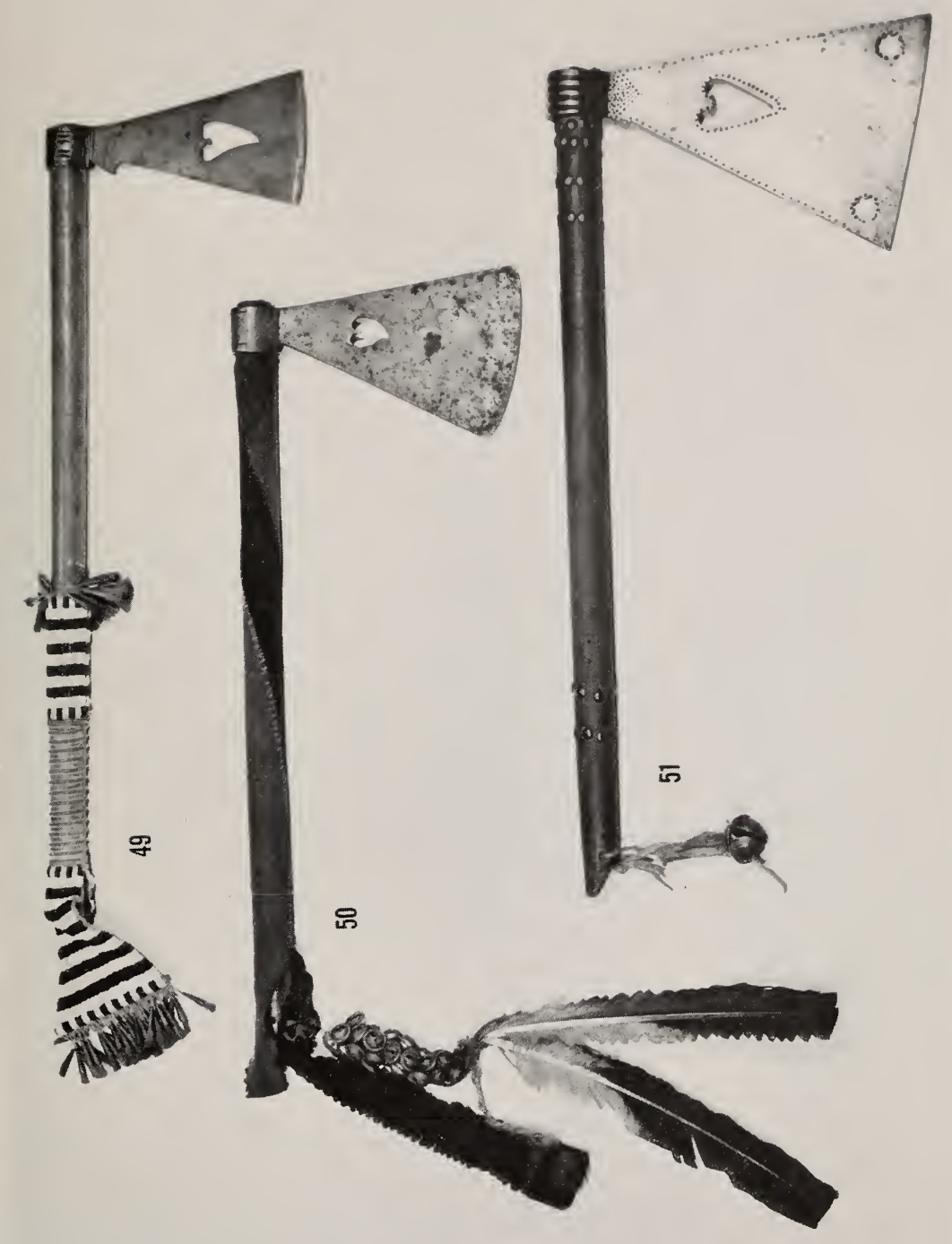




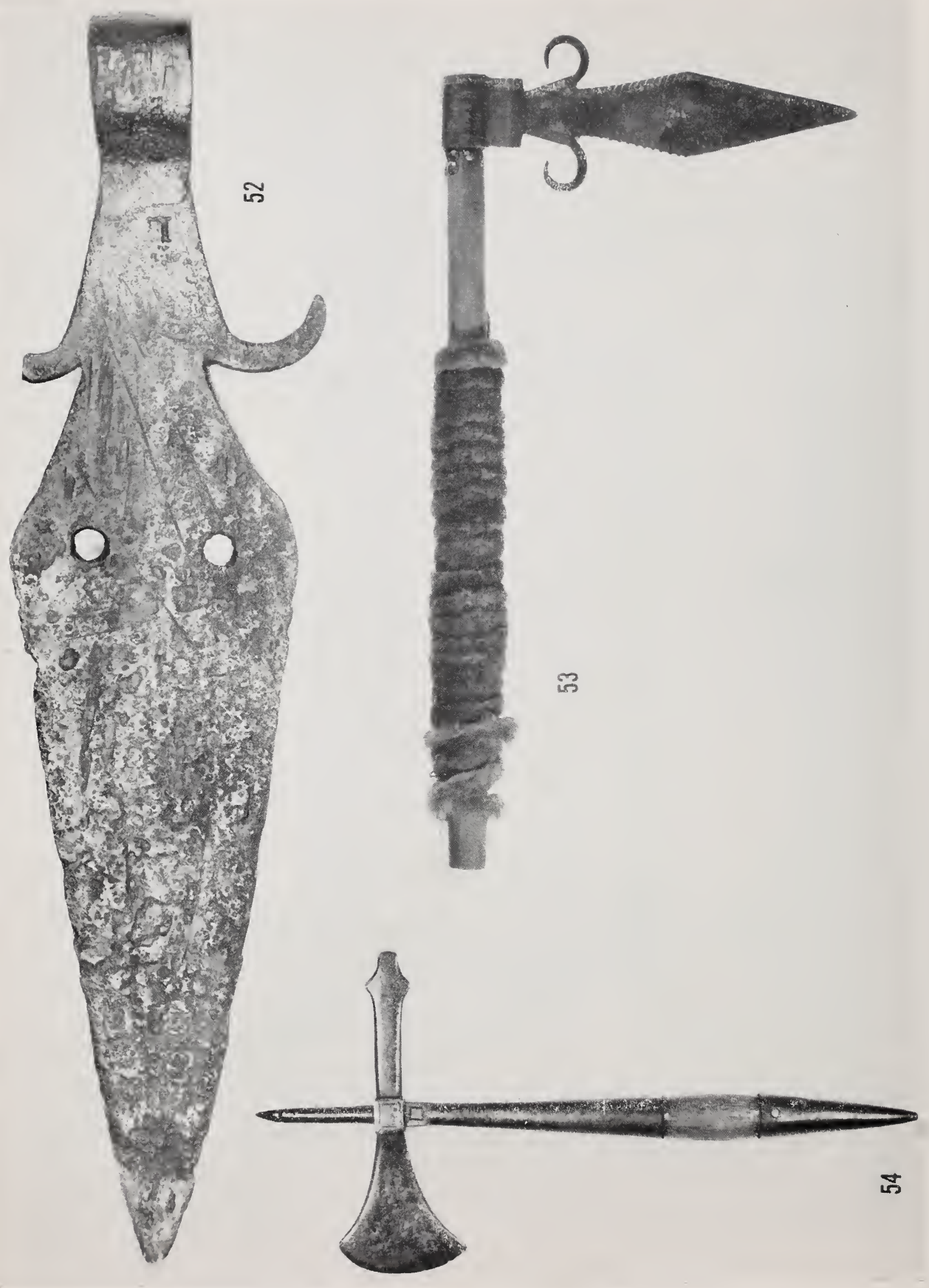


요

w

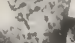

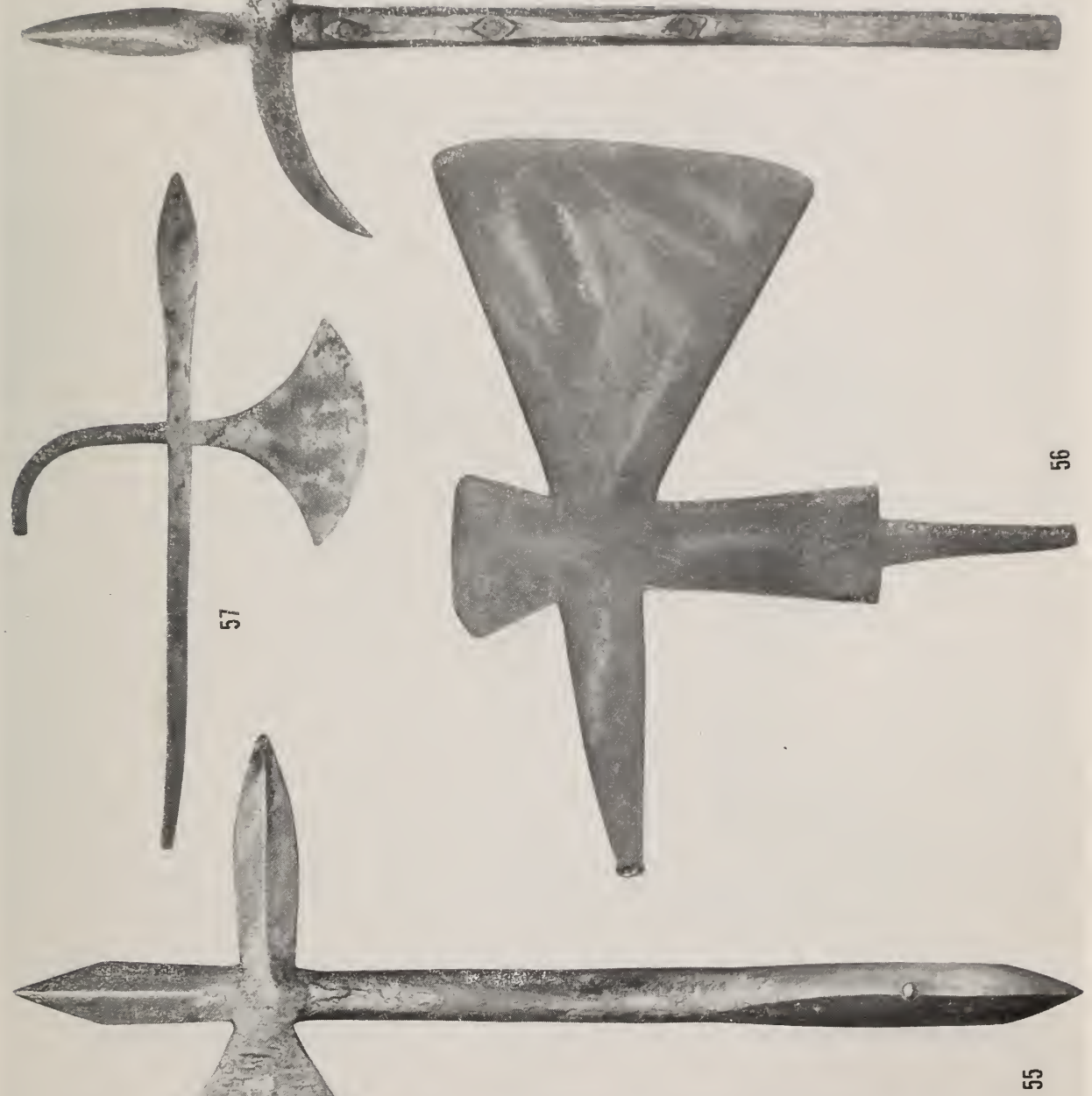





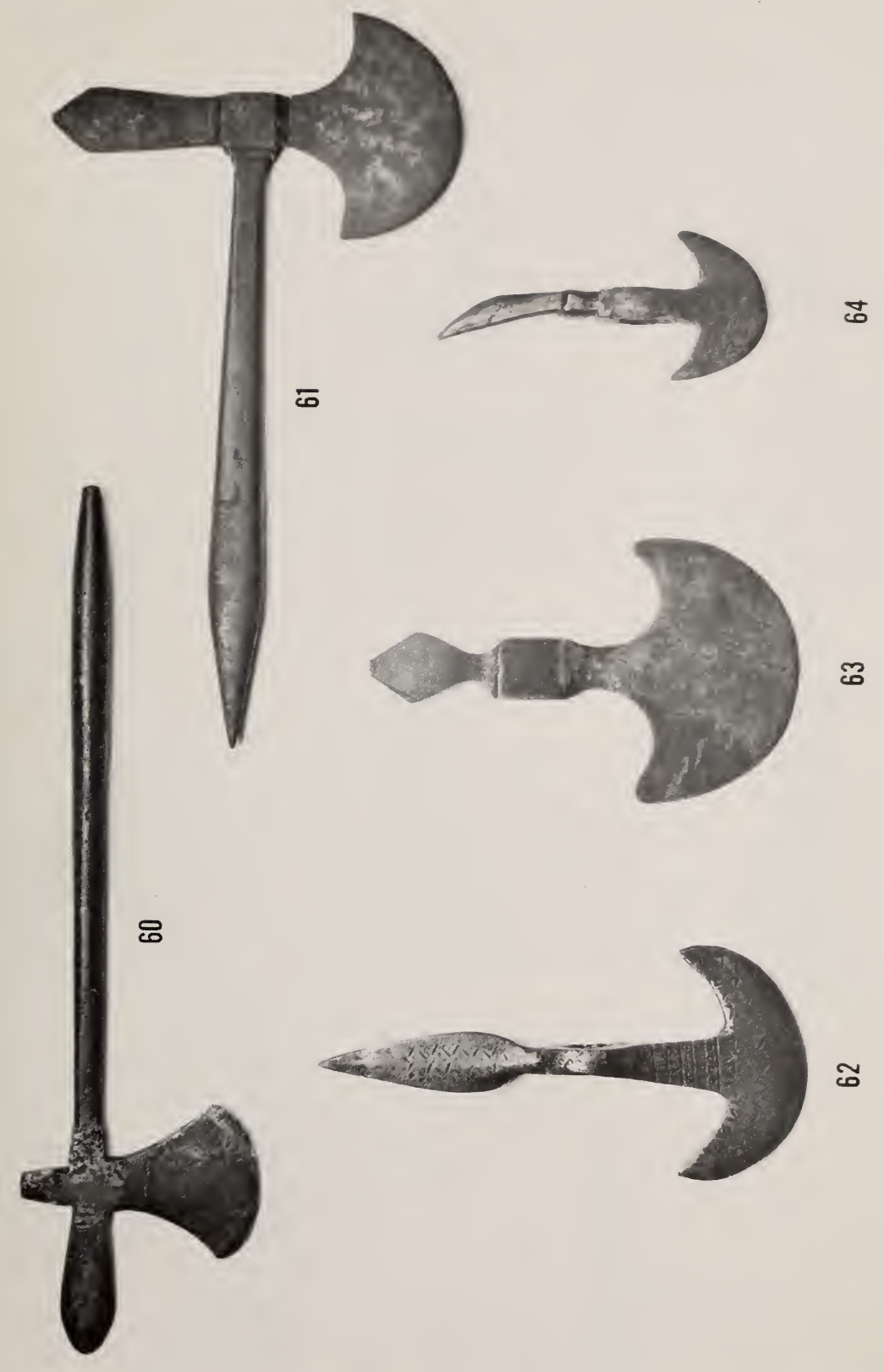



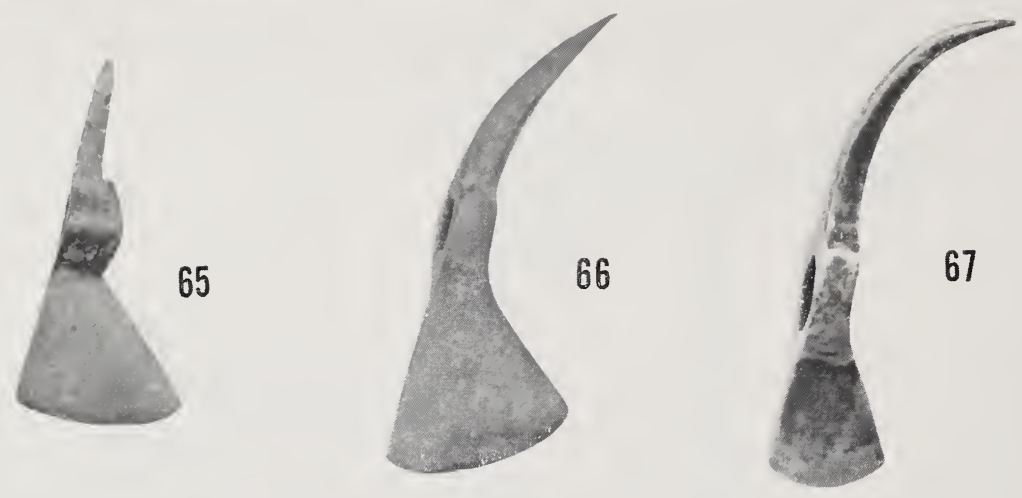

68
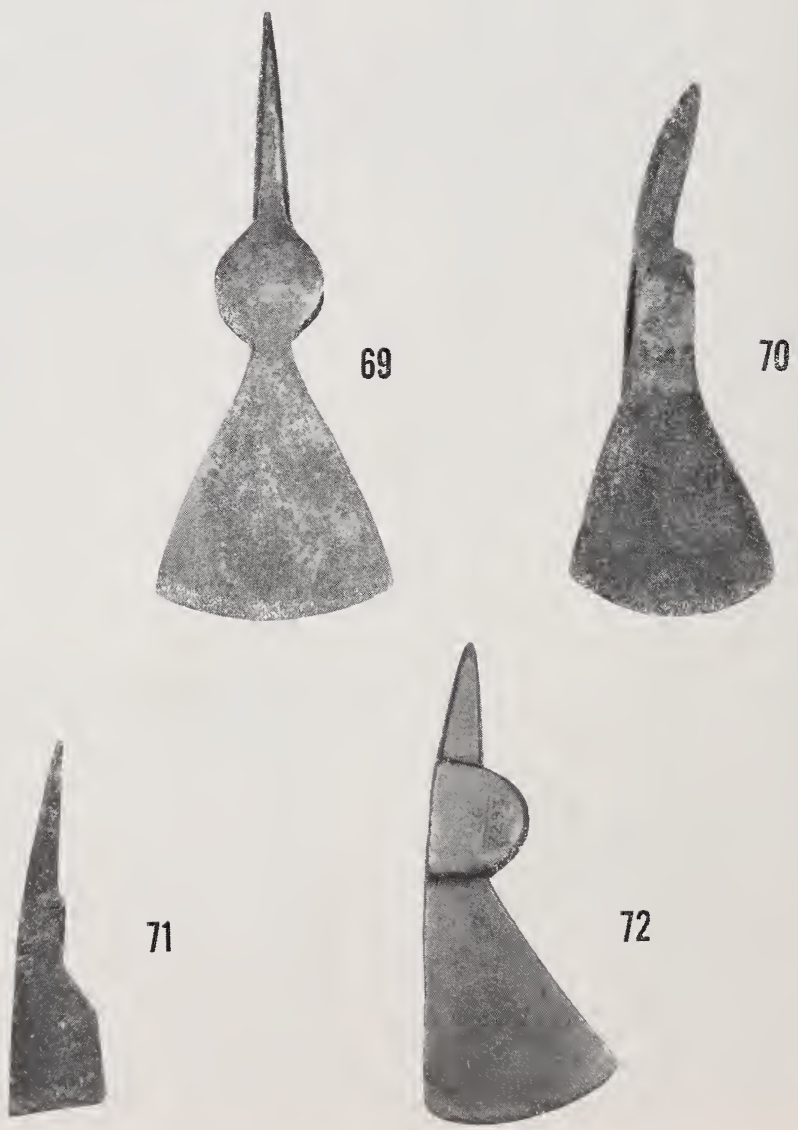


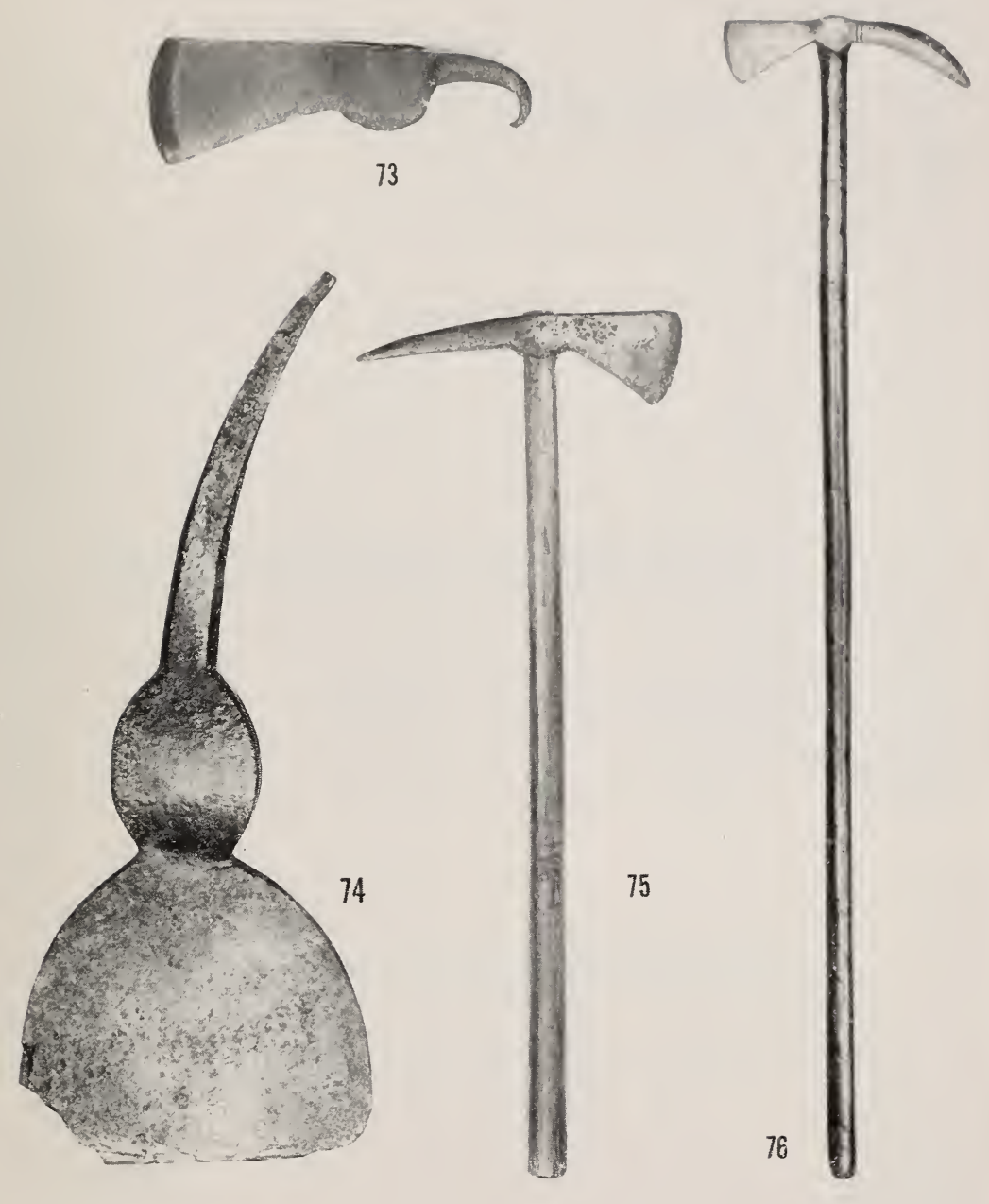




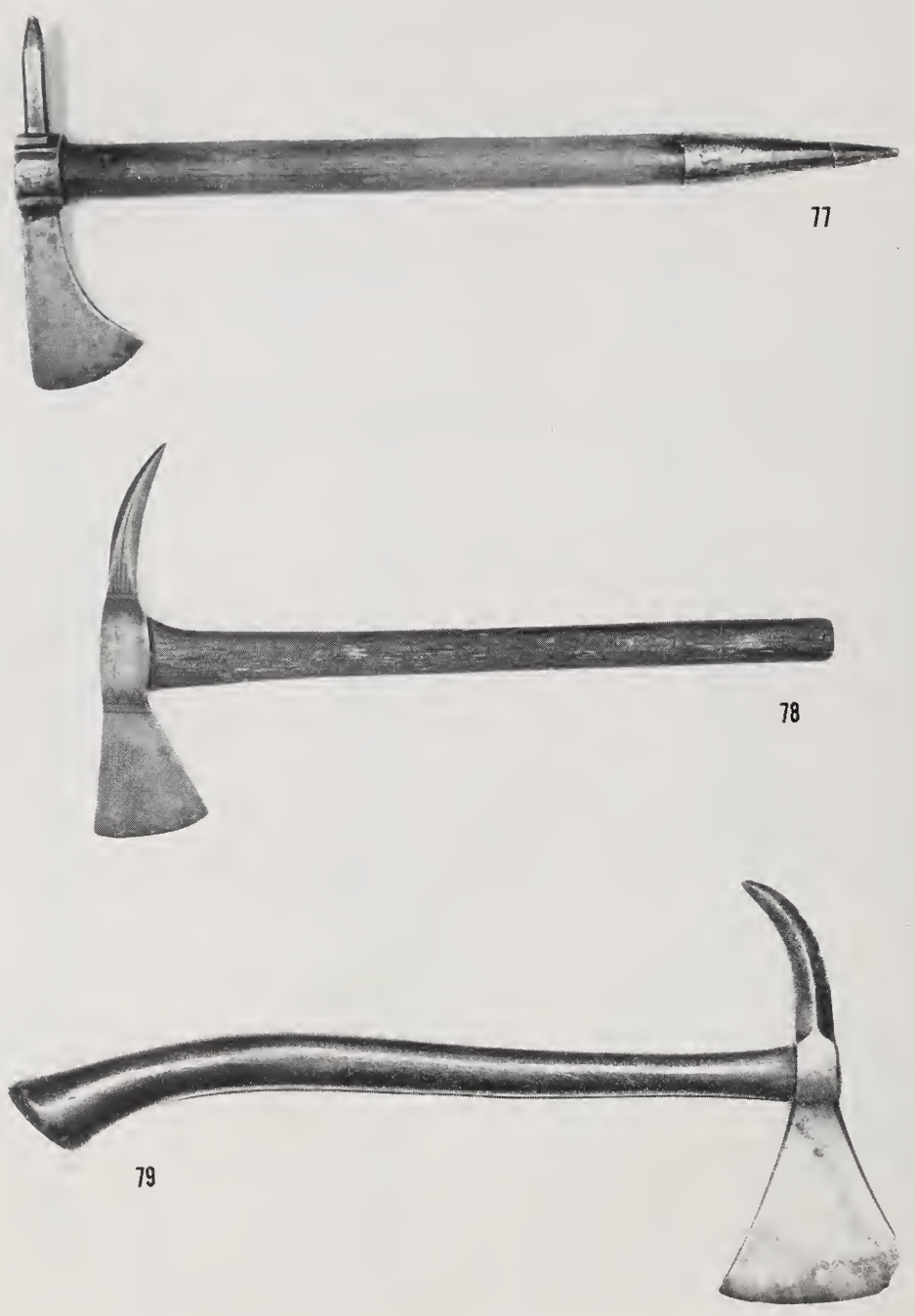



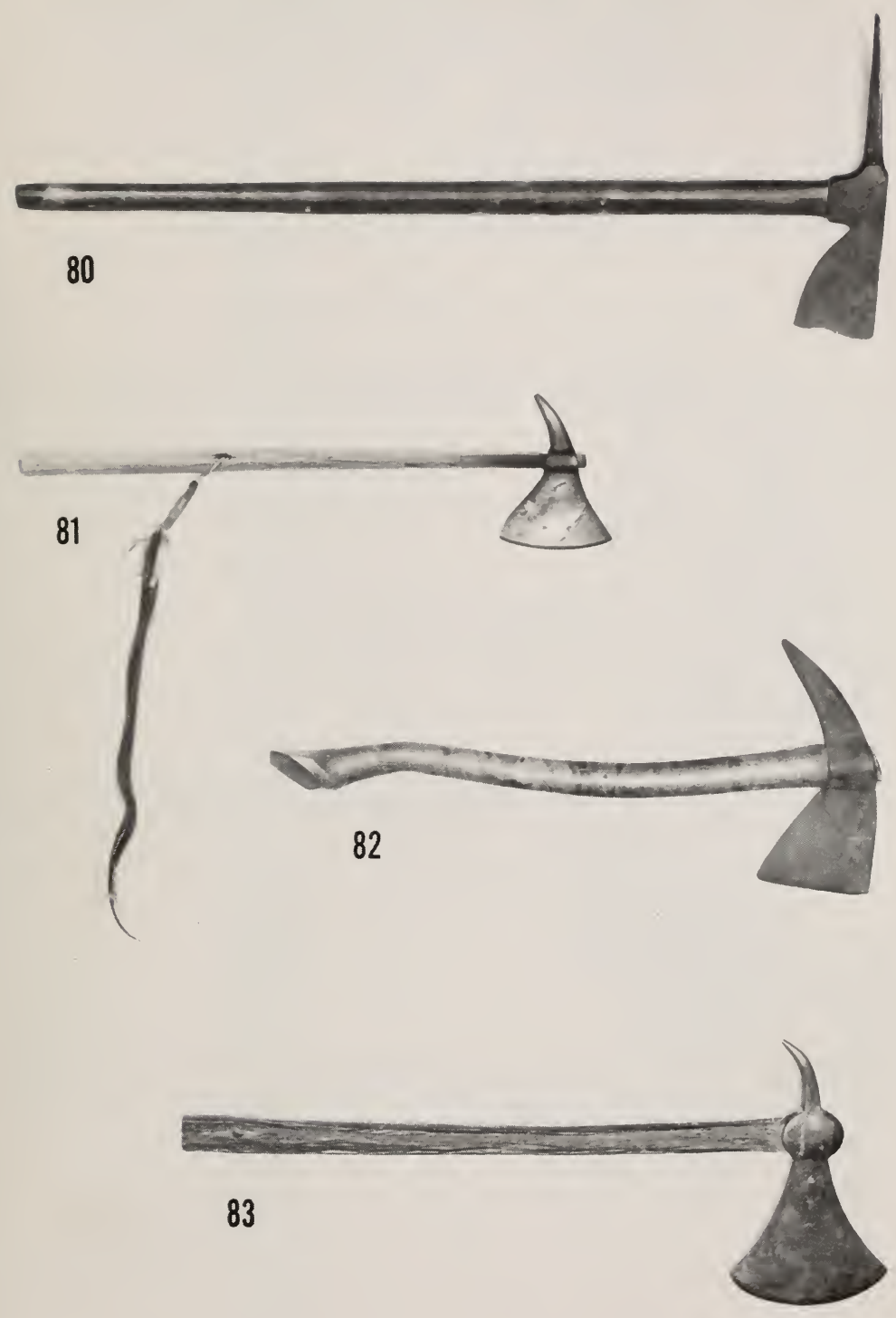


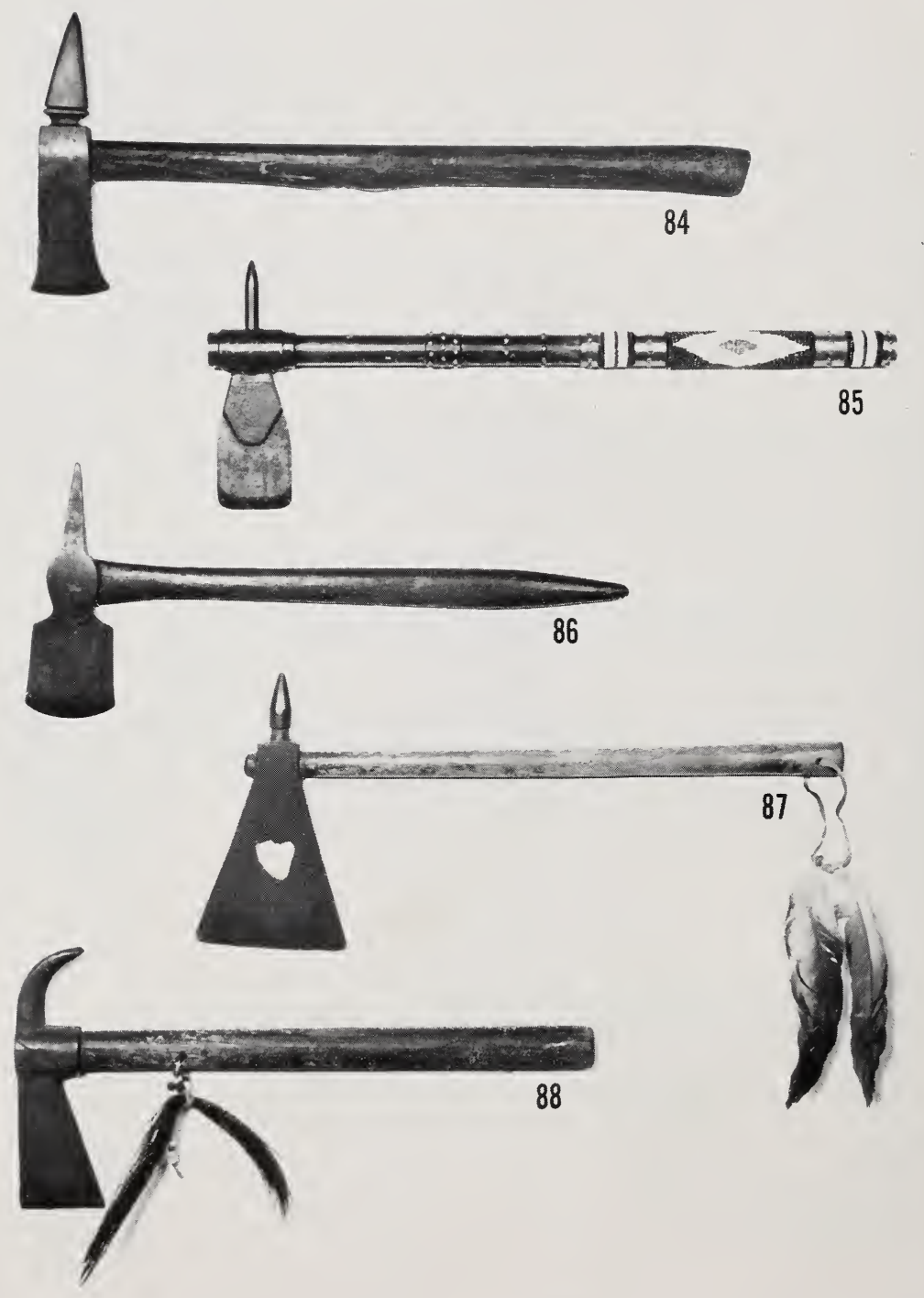




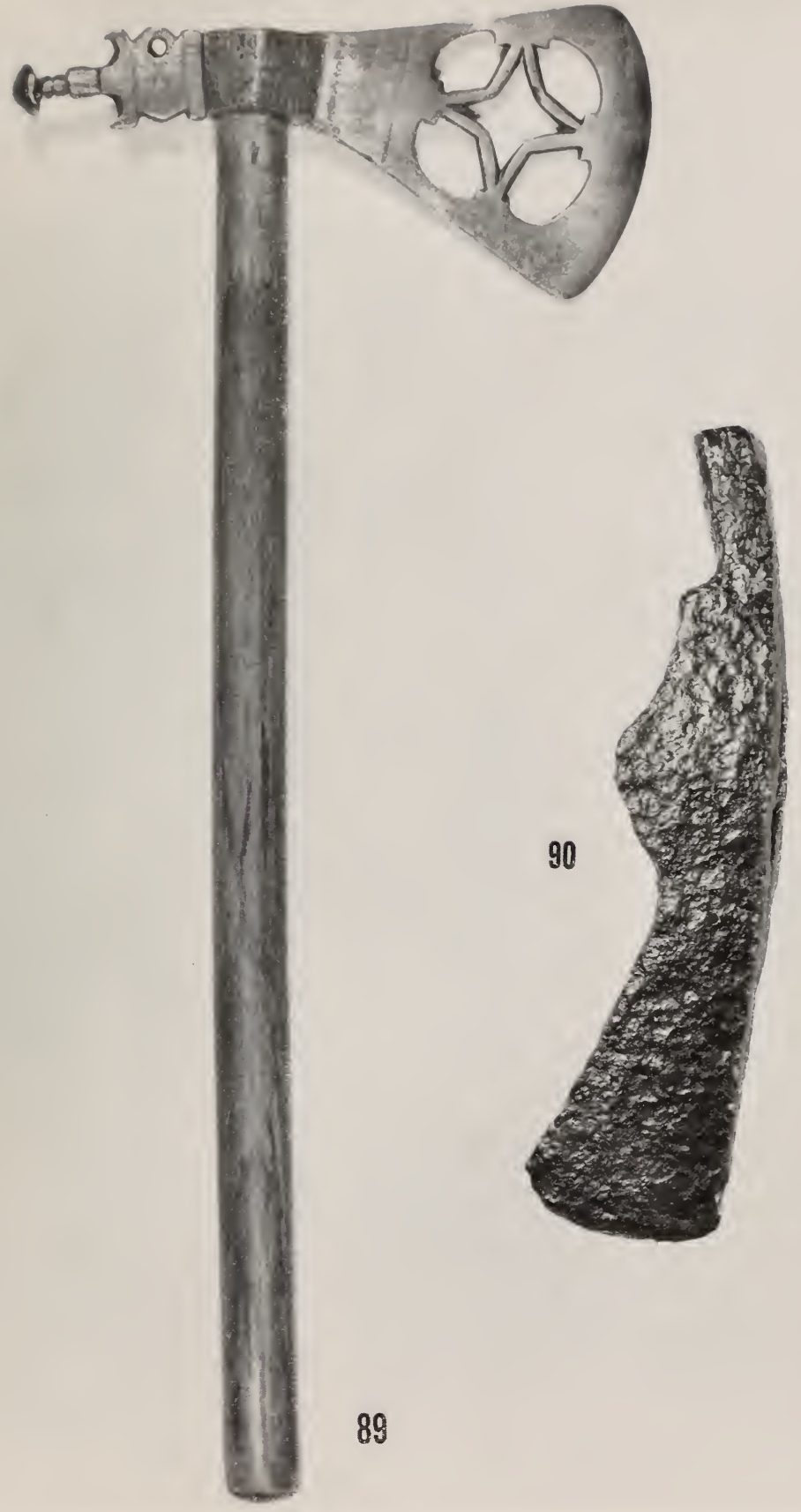




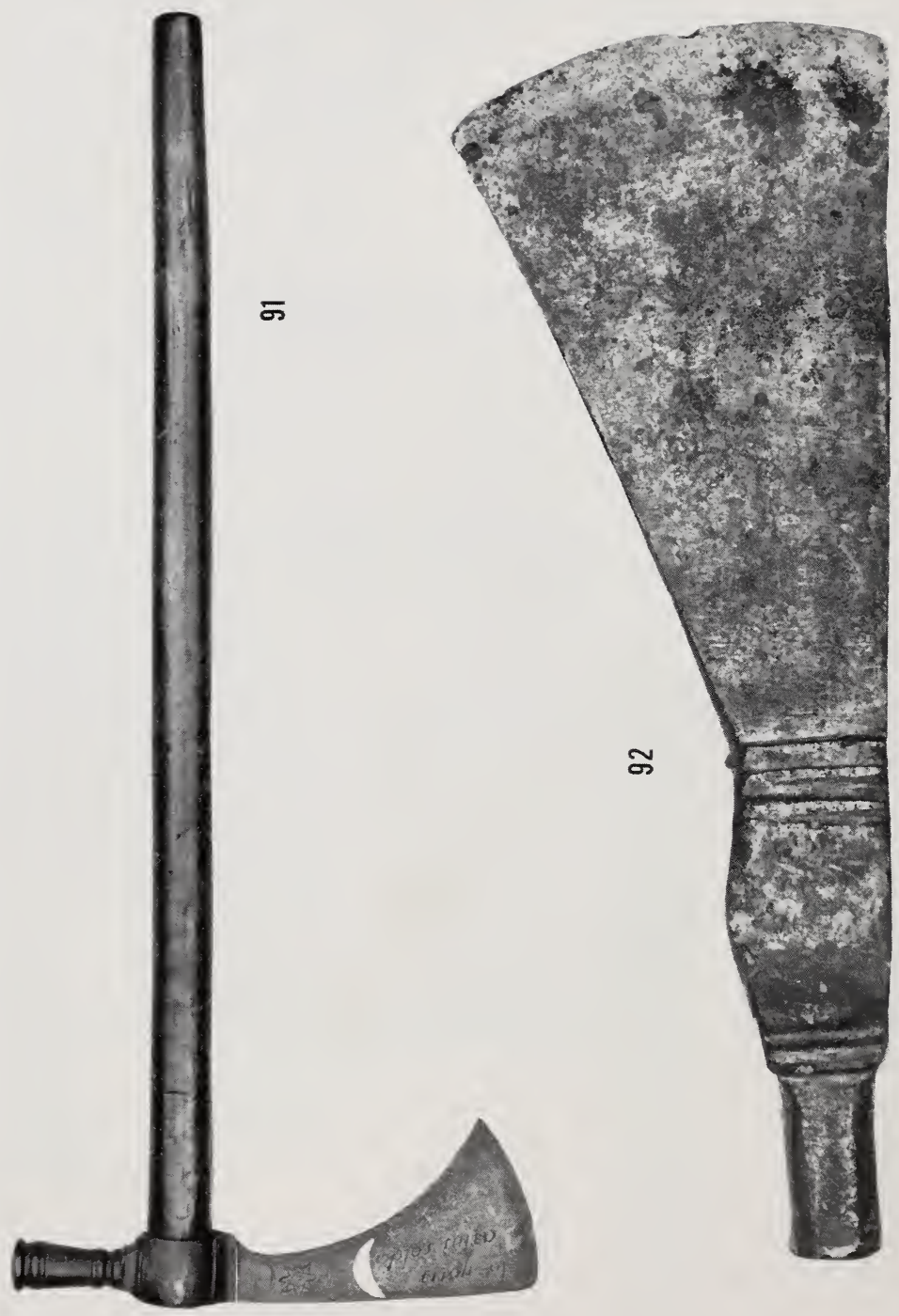




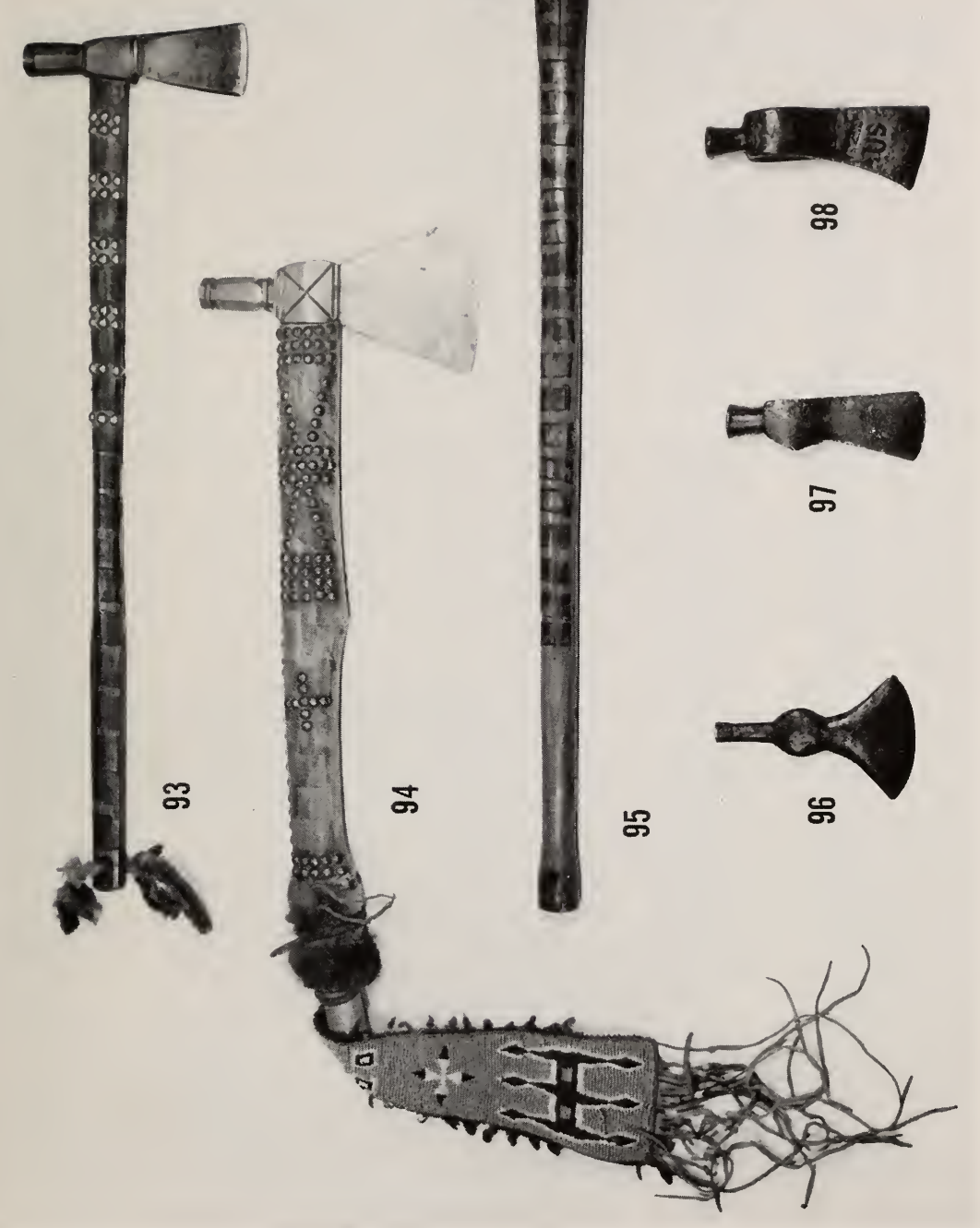




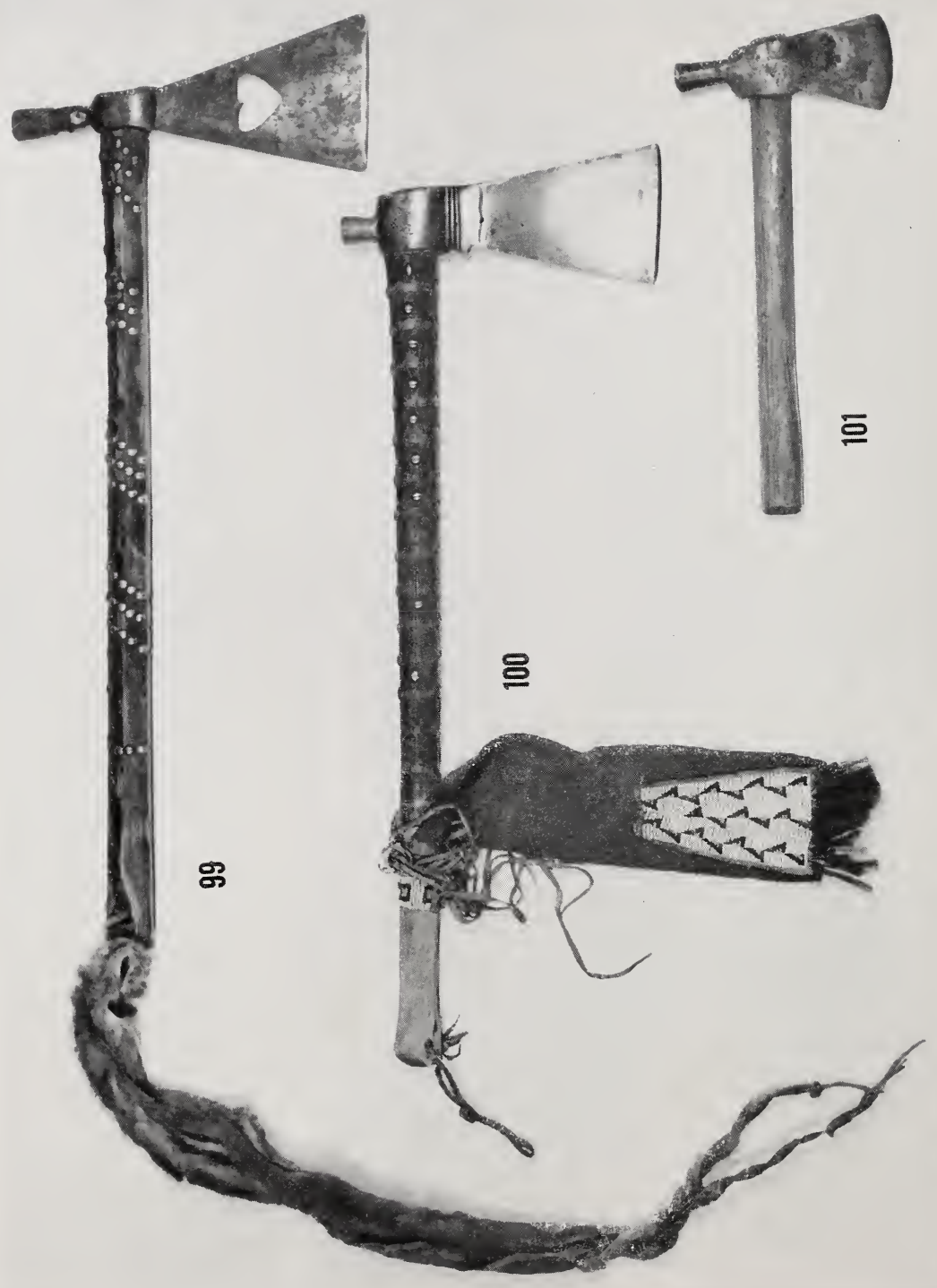




$$
T
$$




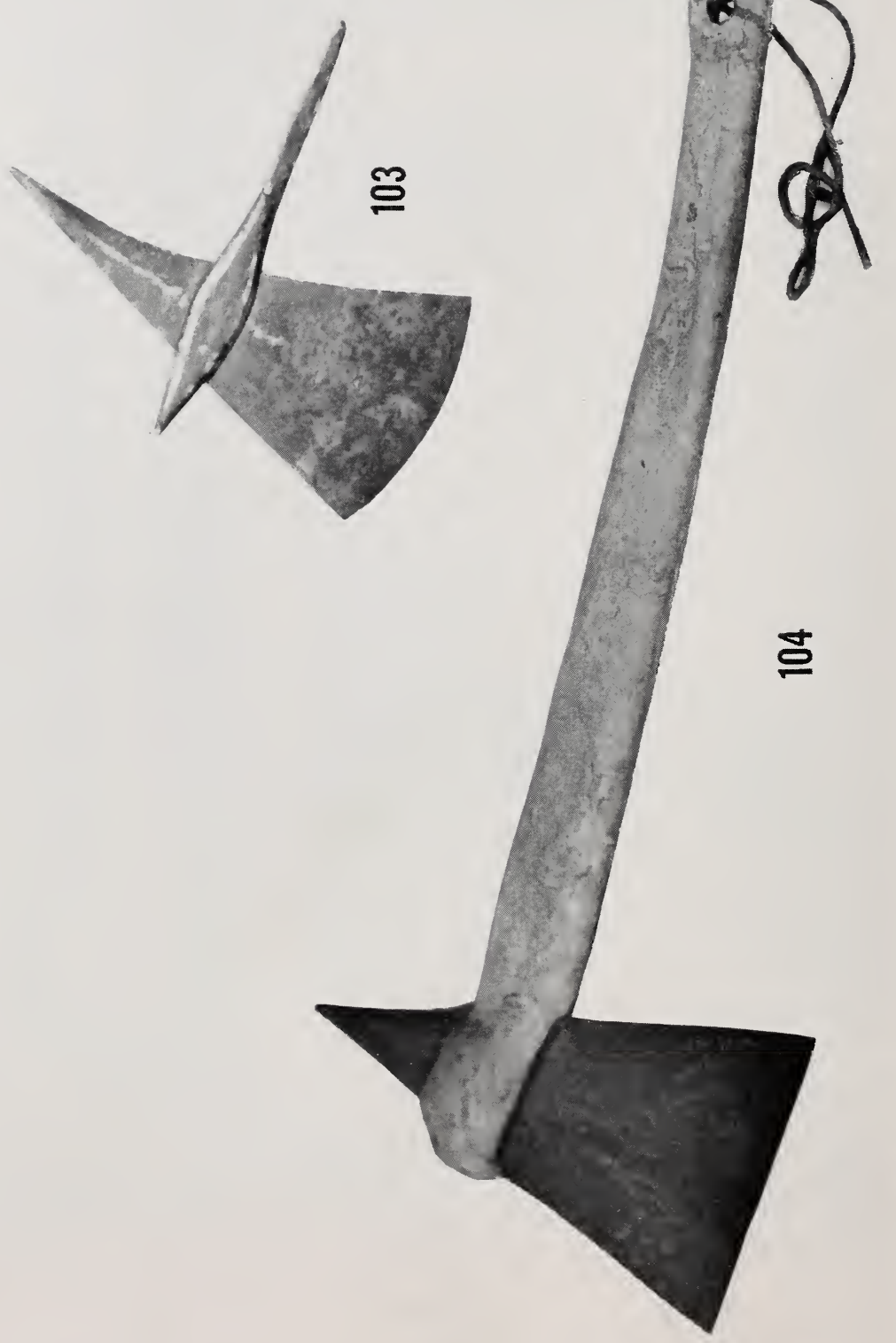




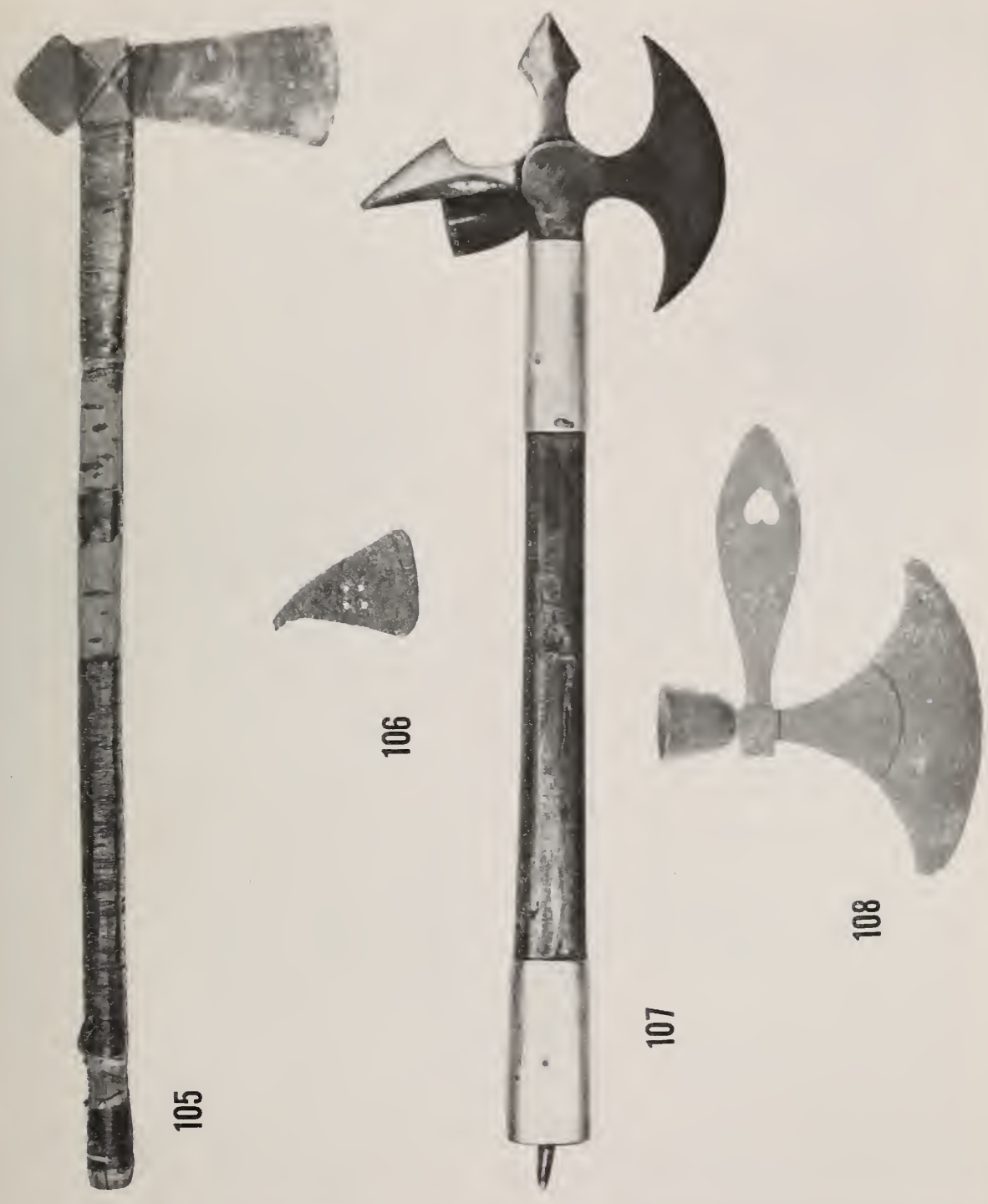




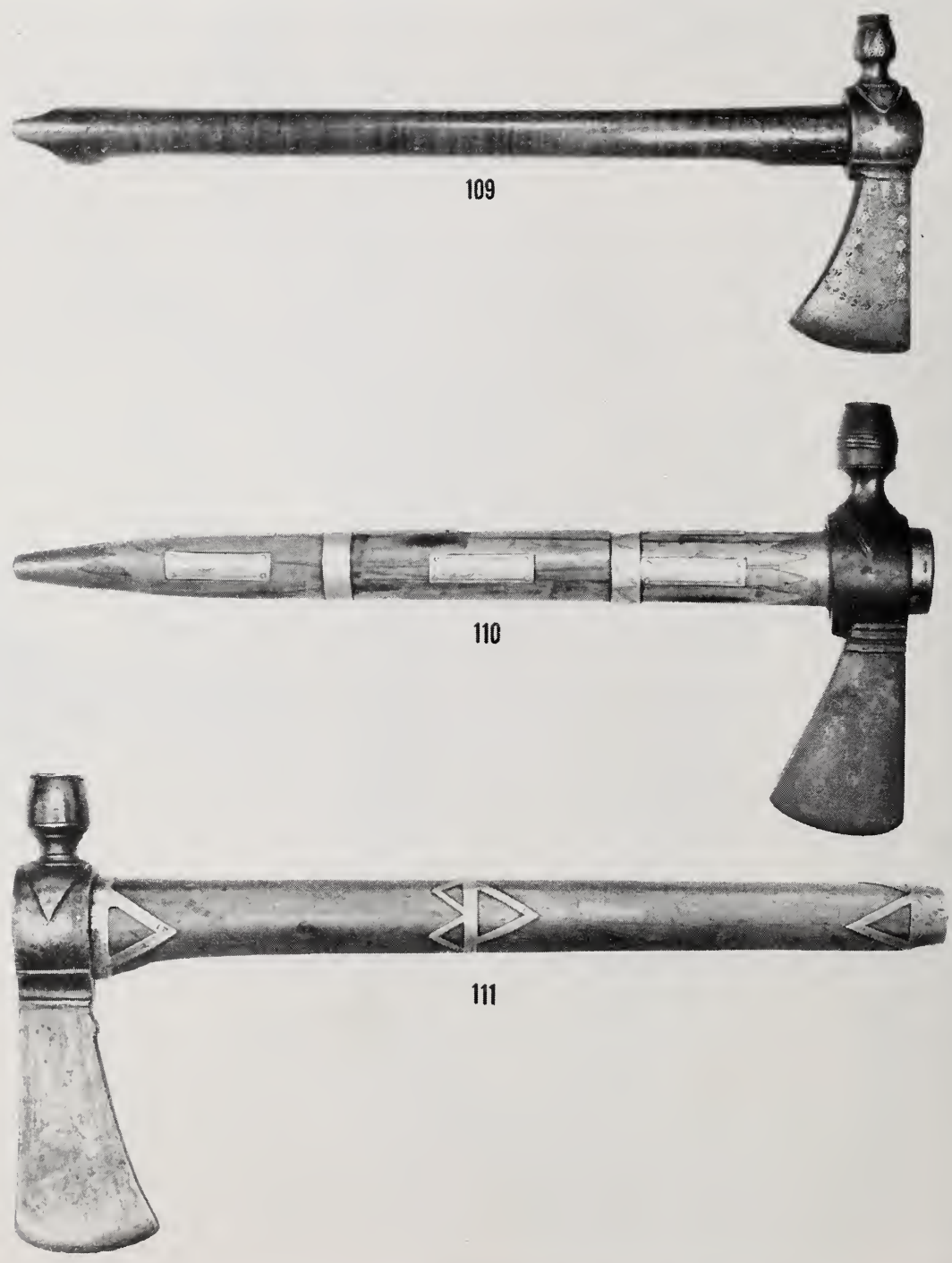



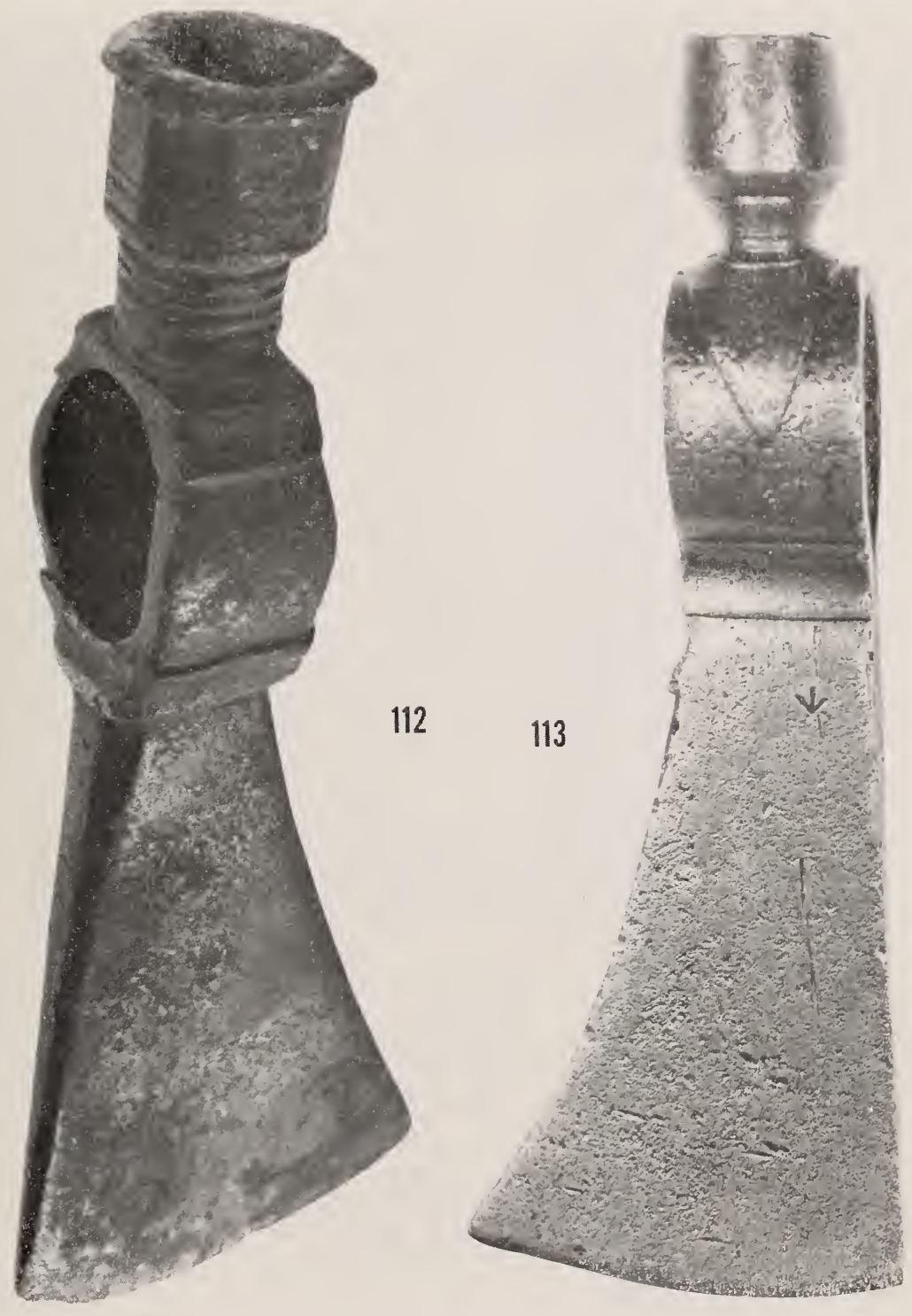


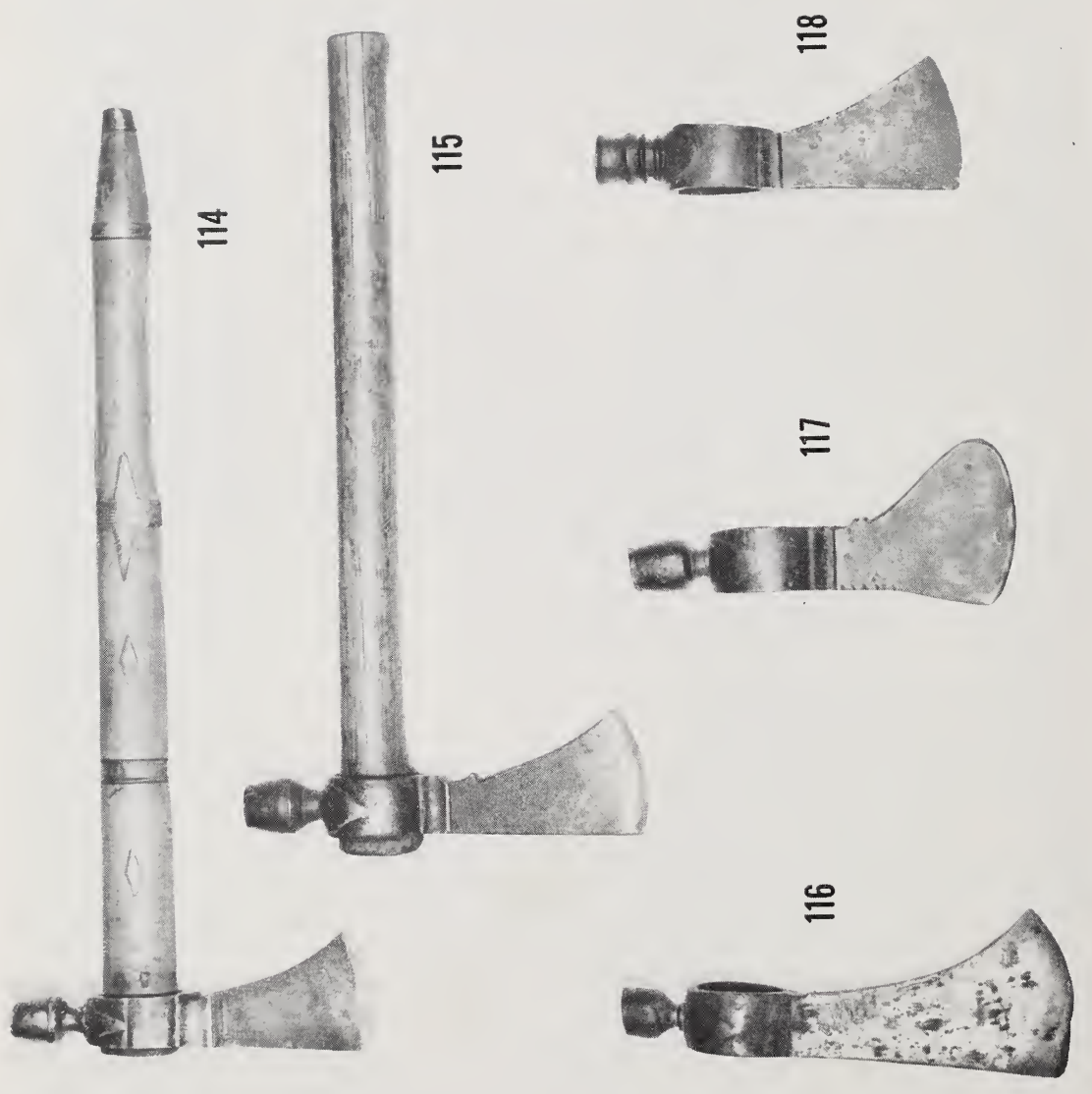



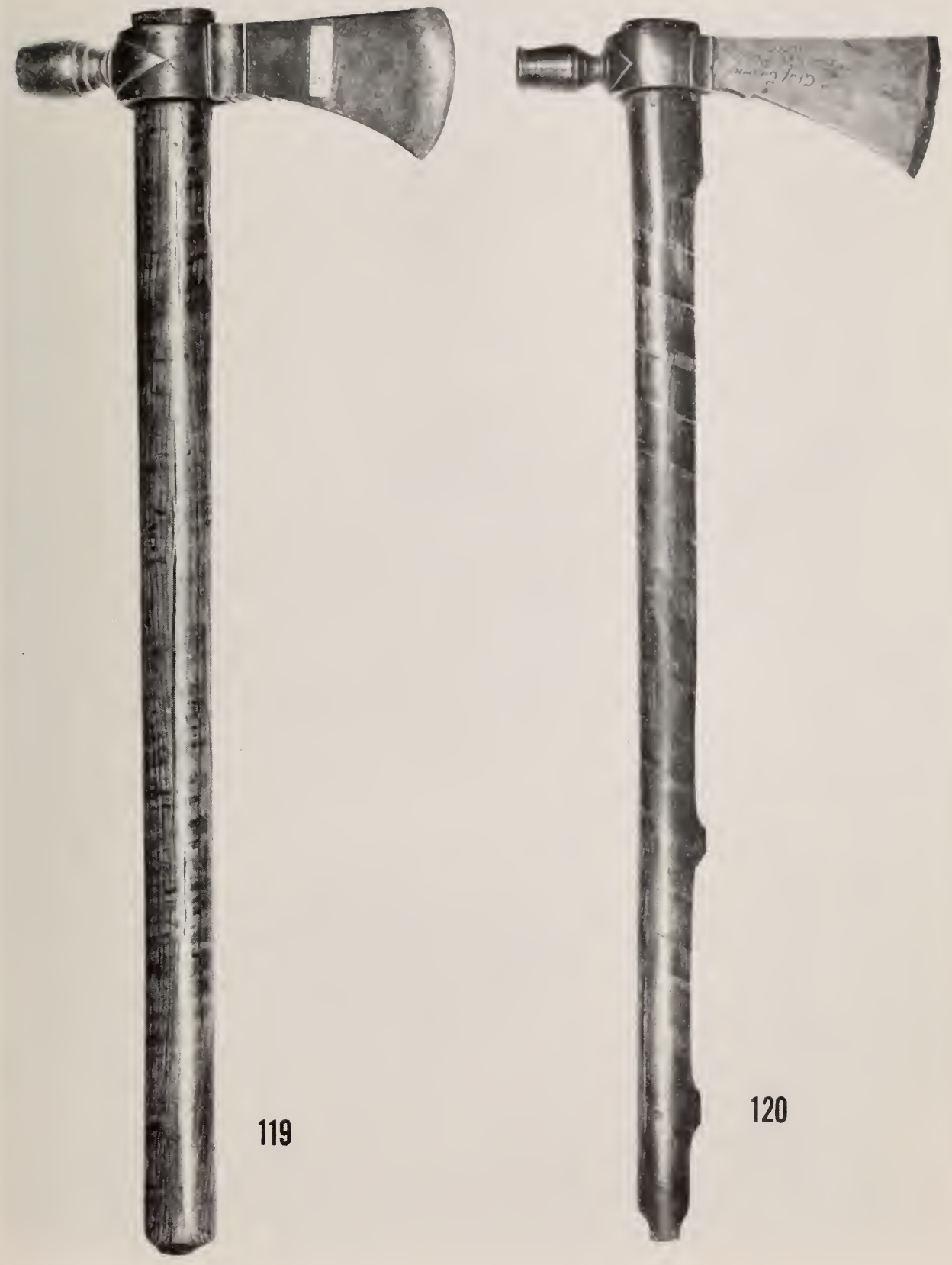

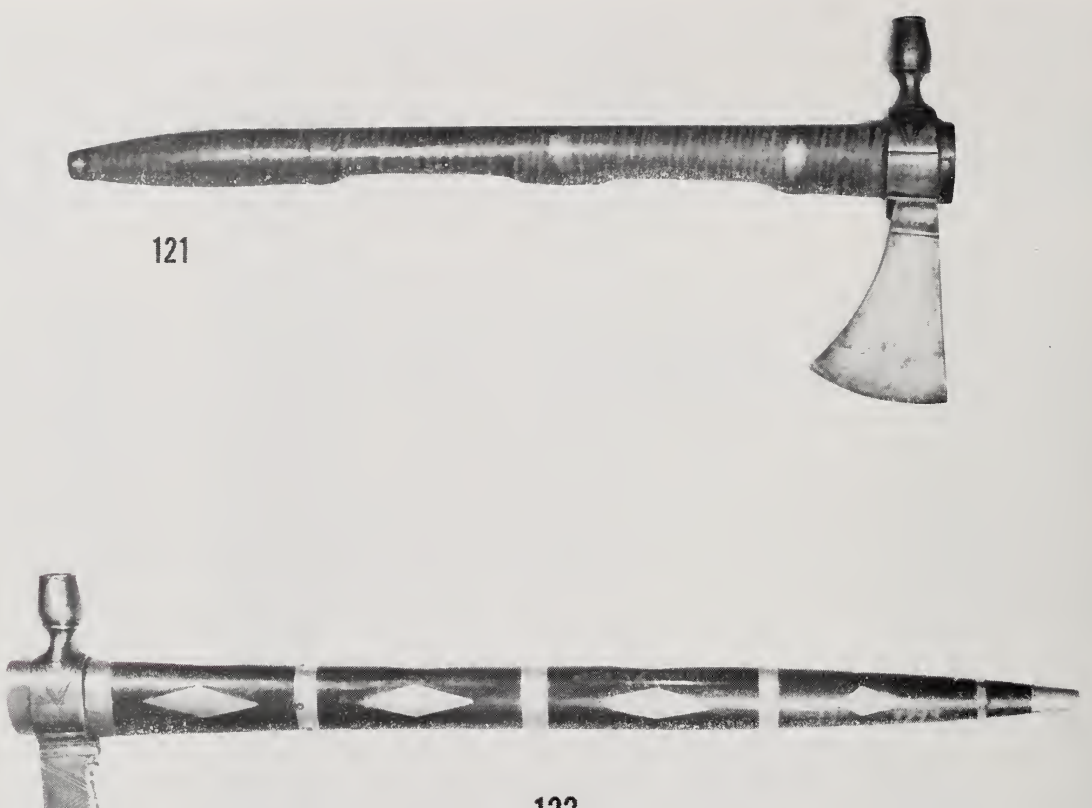

122

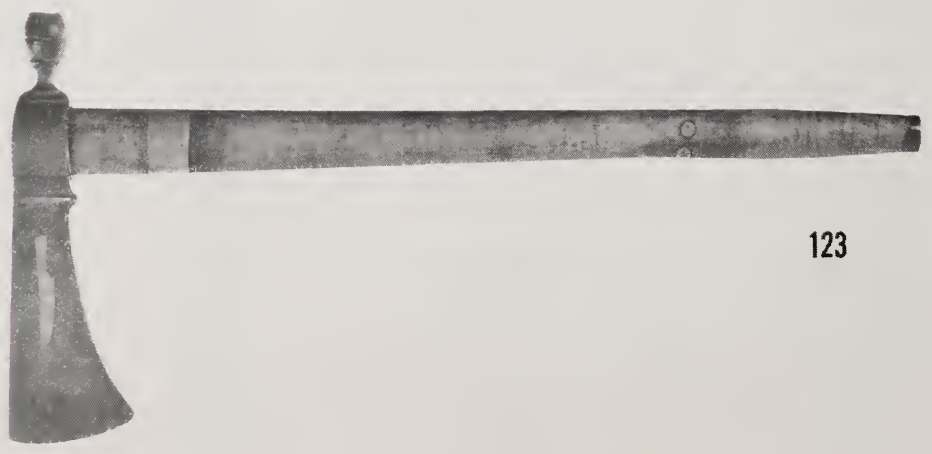



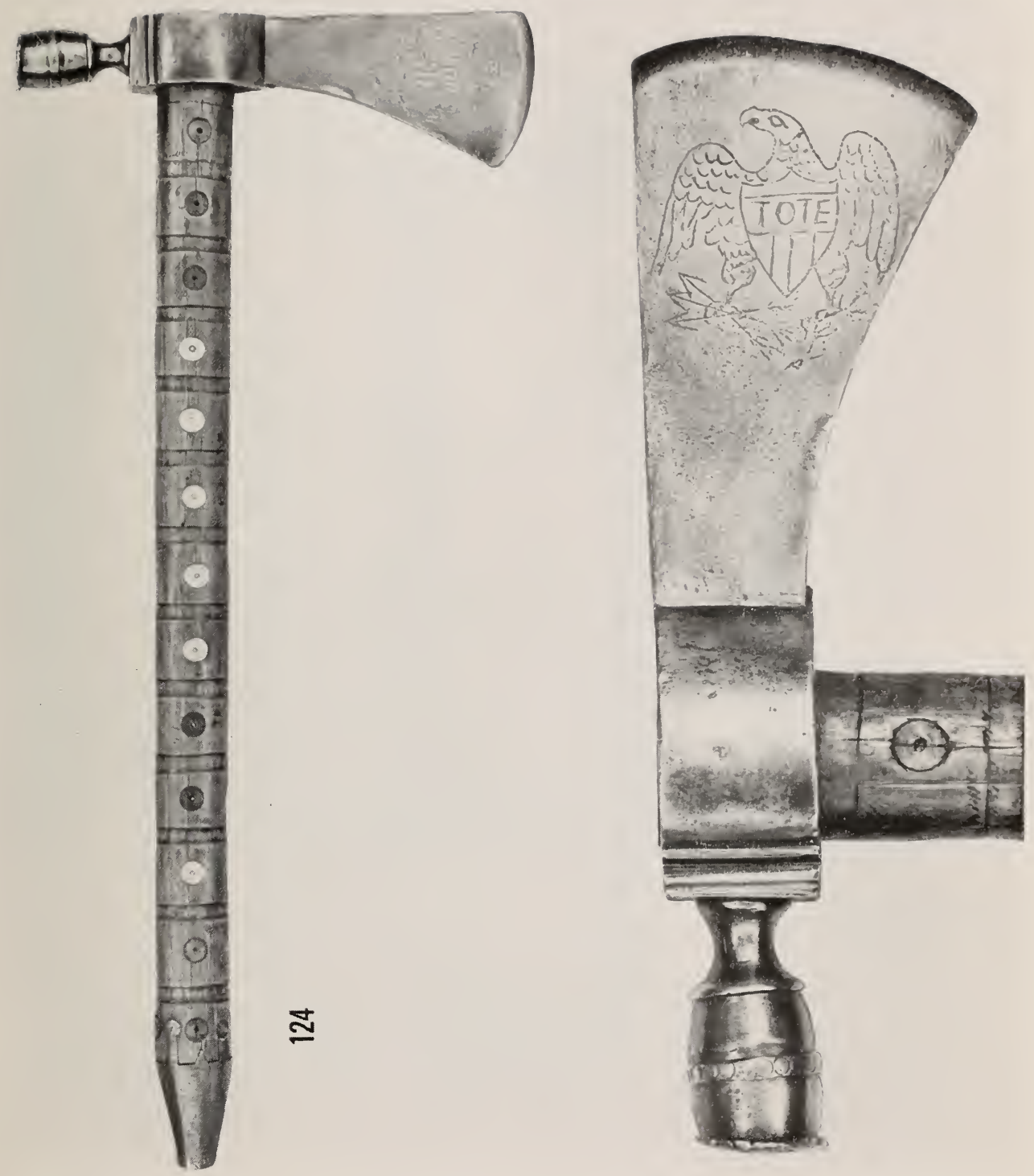


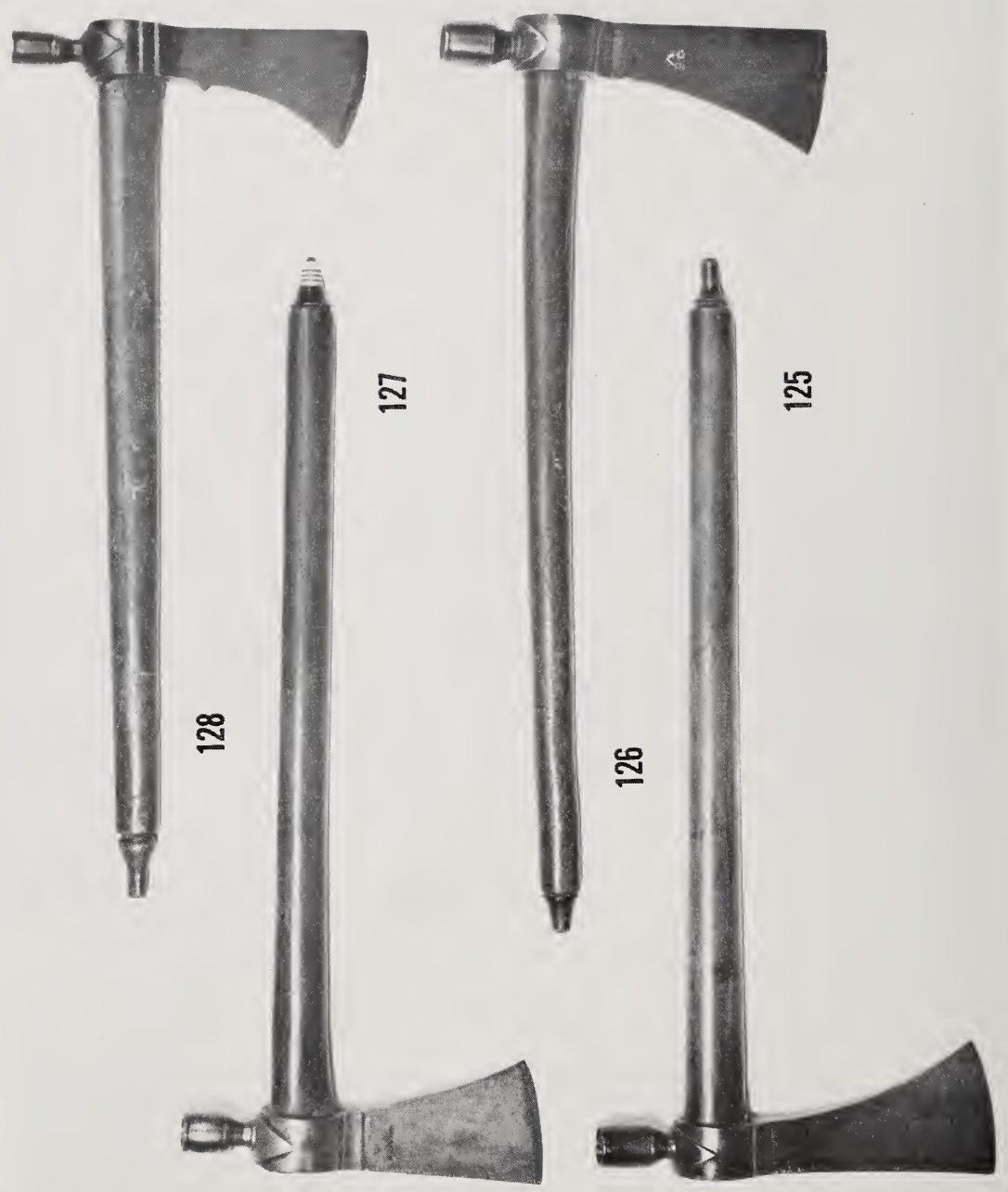



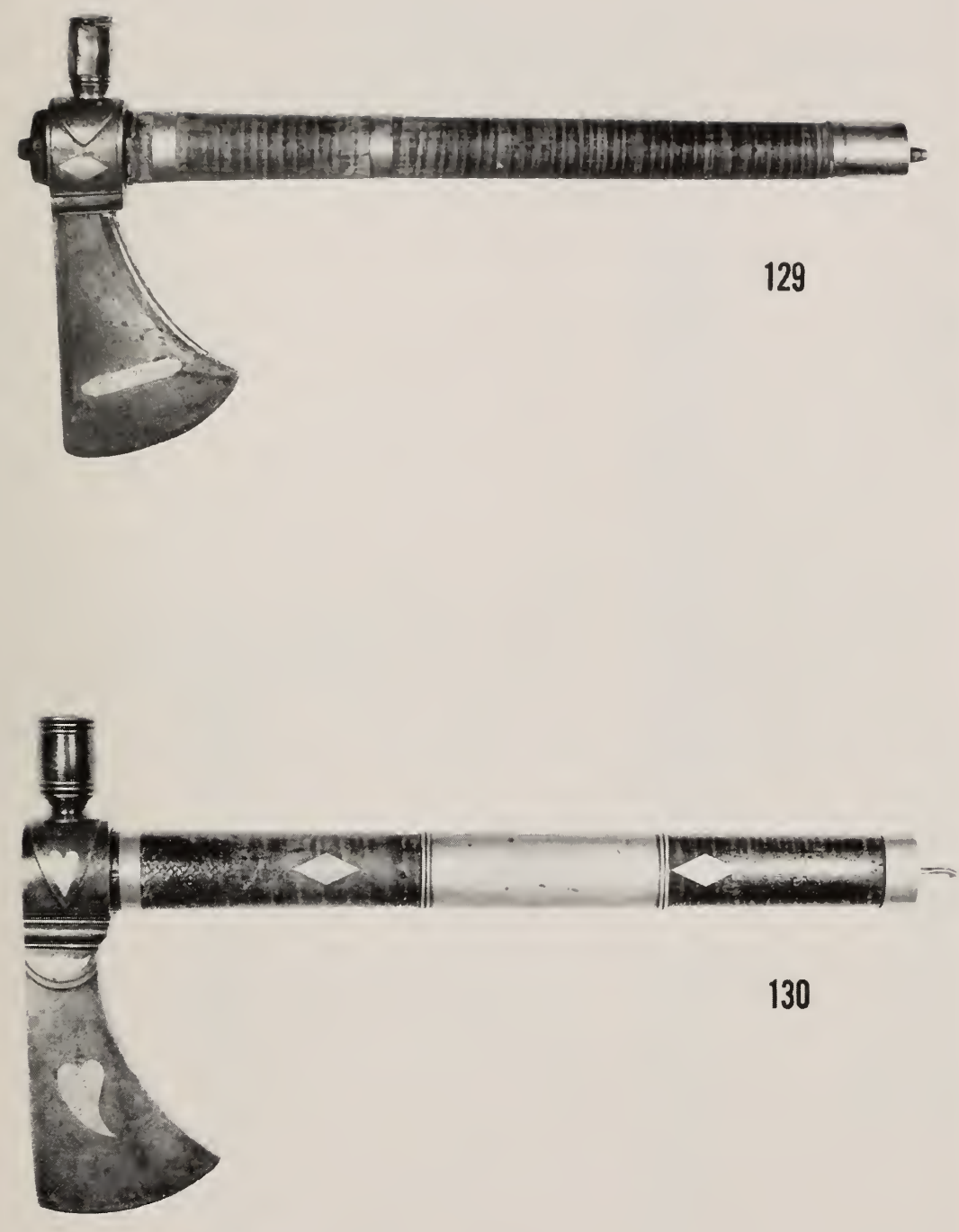

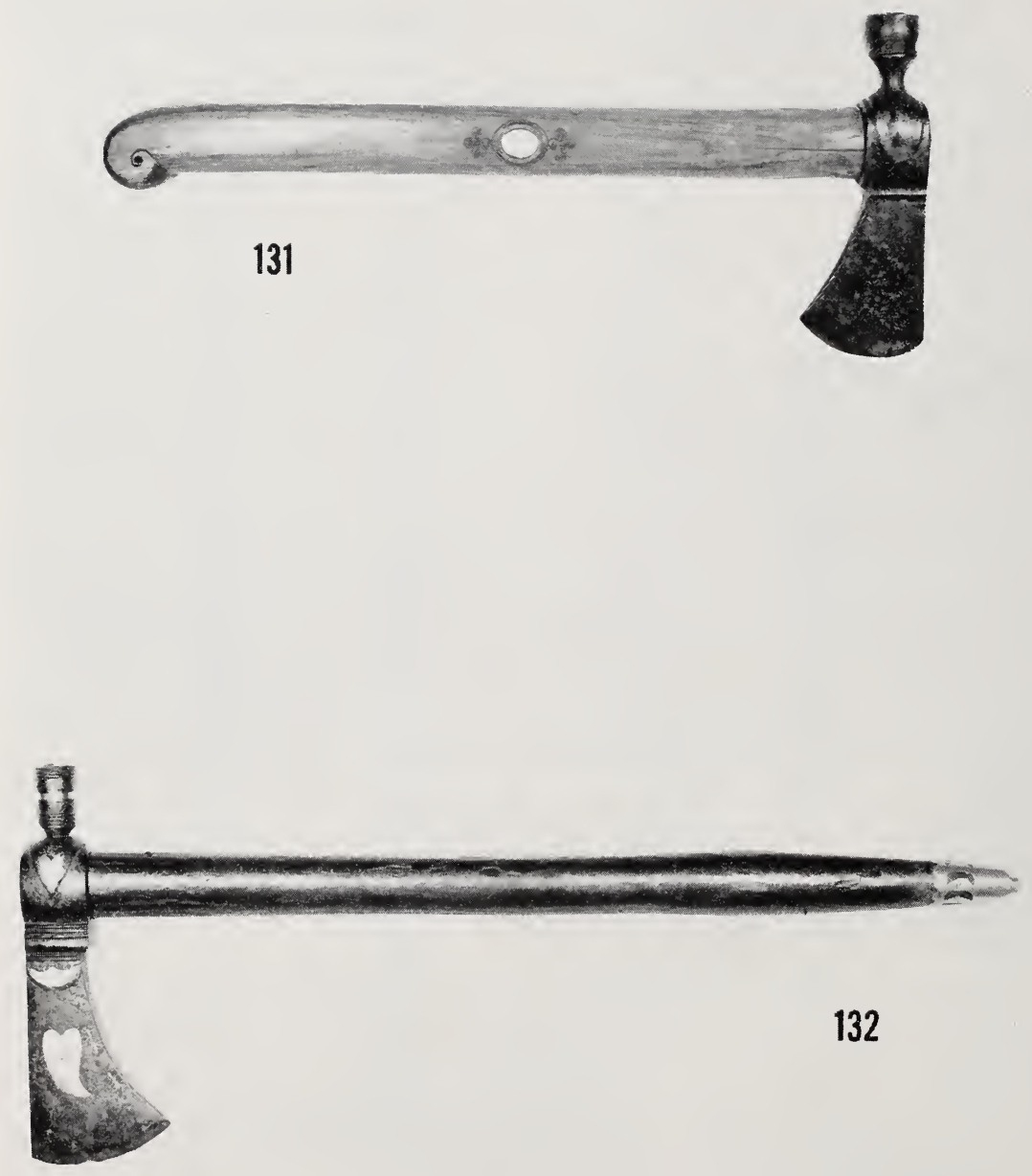


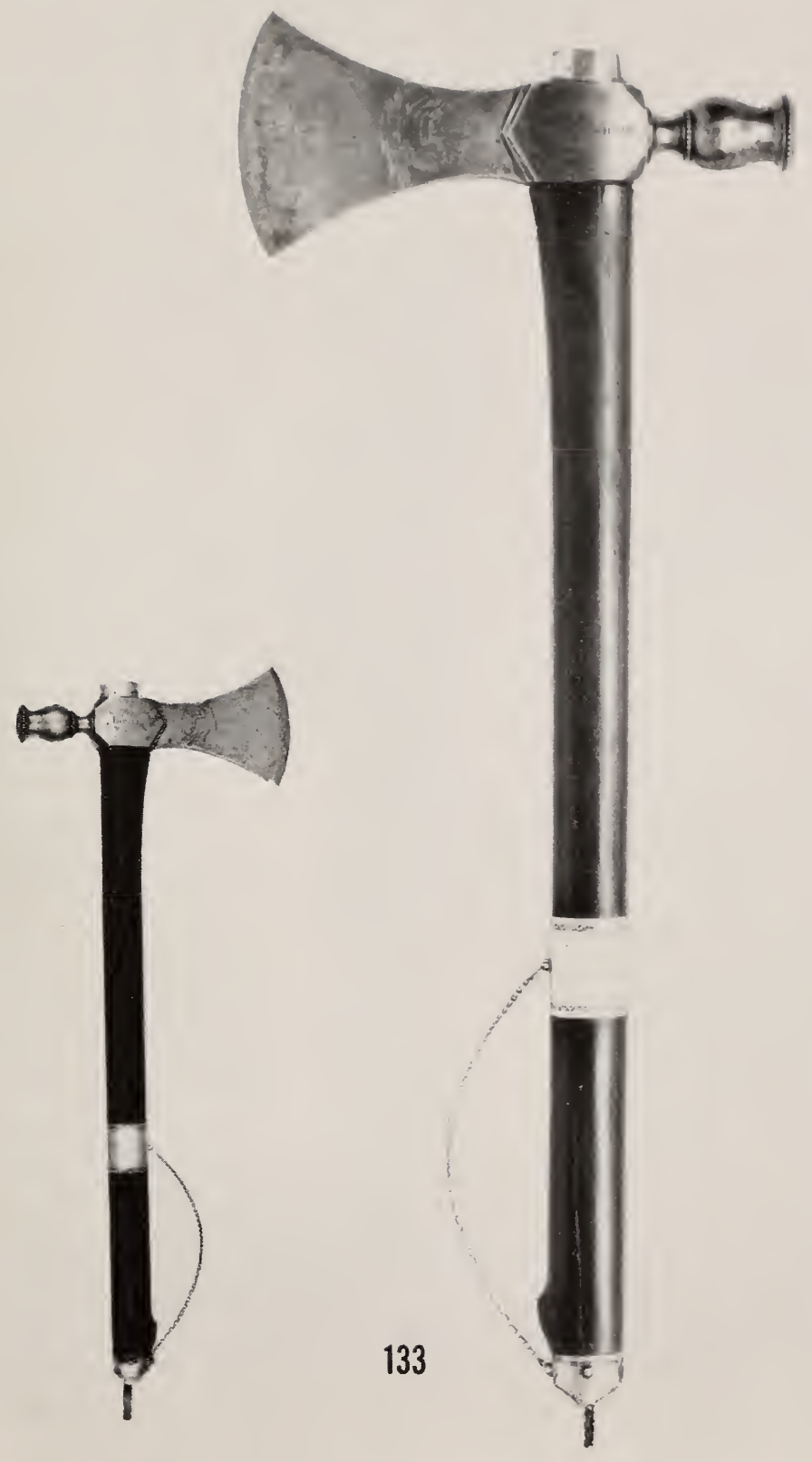




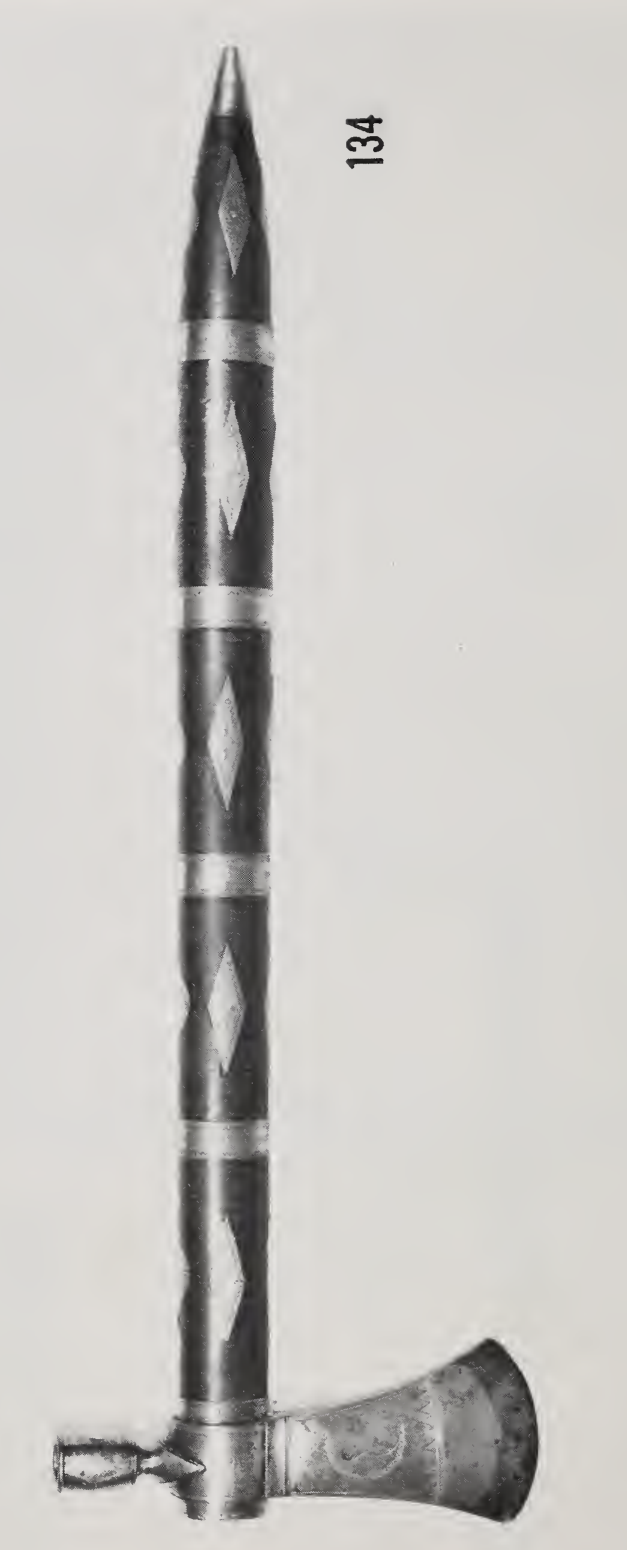




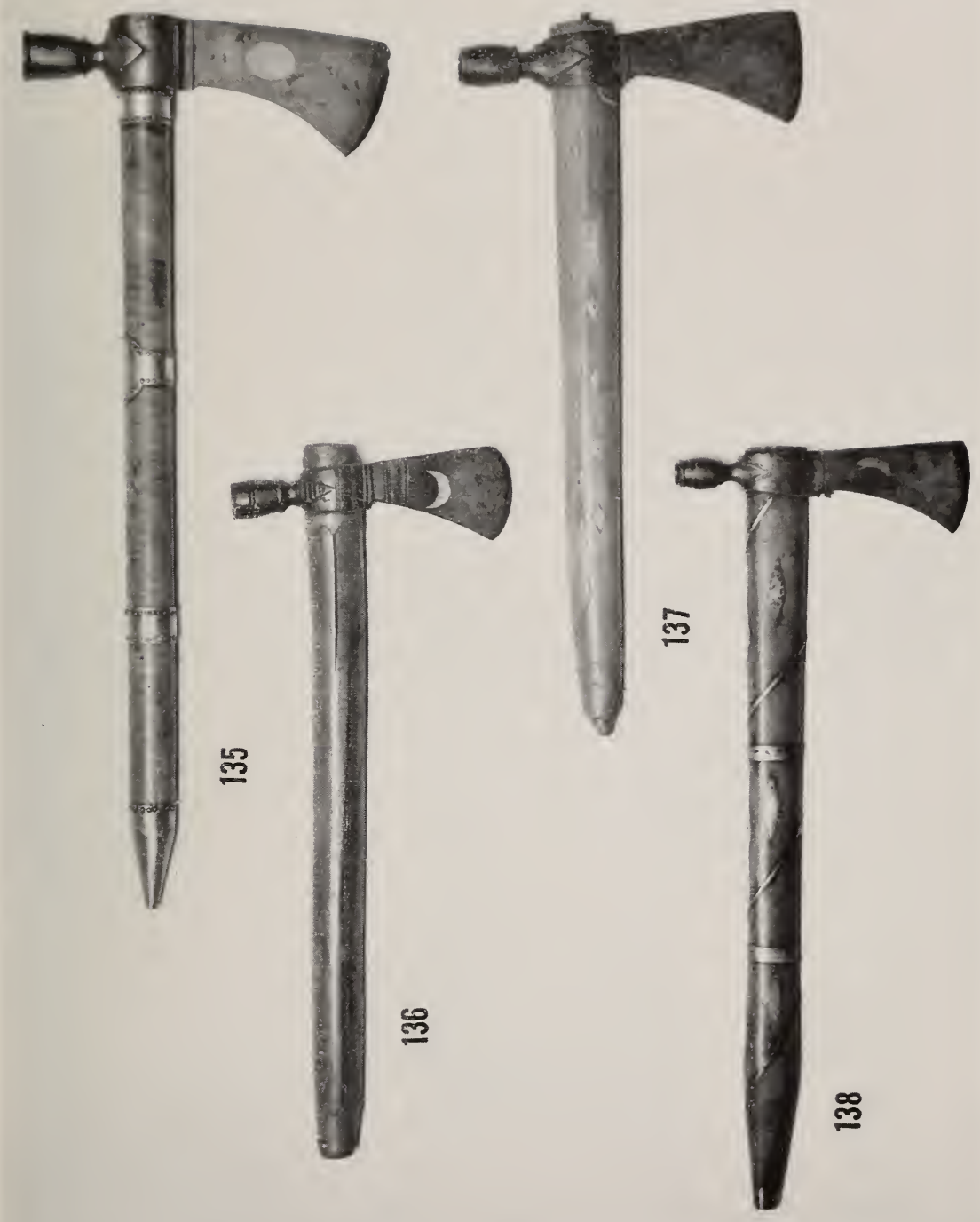



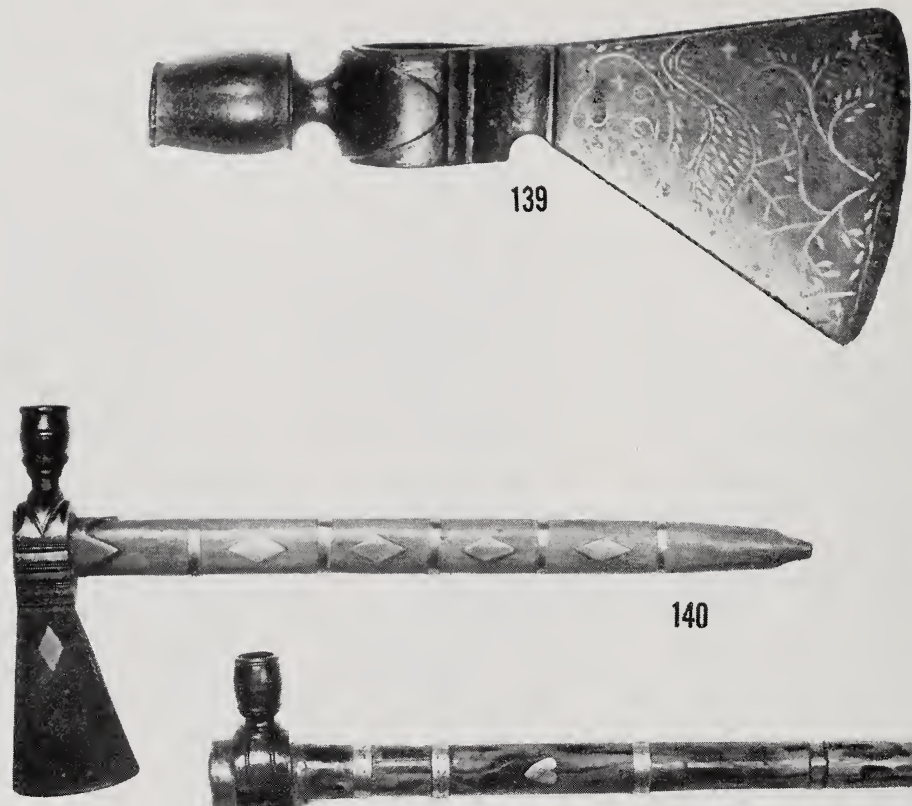

140

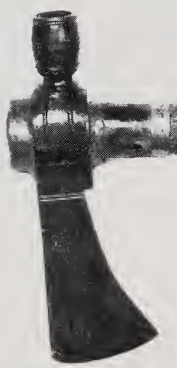

141

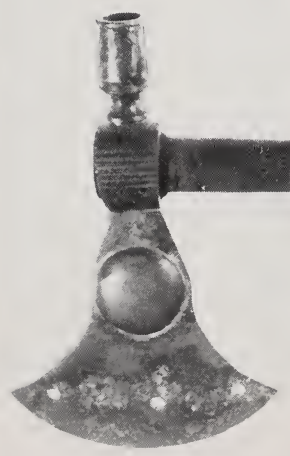




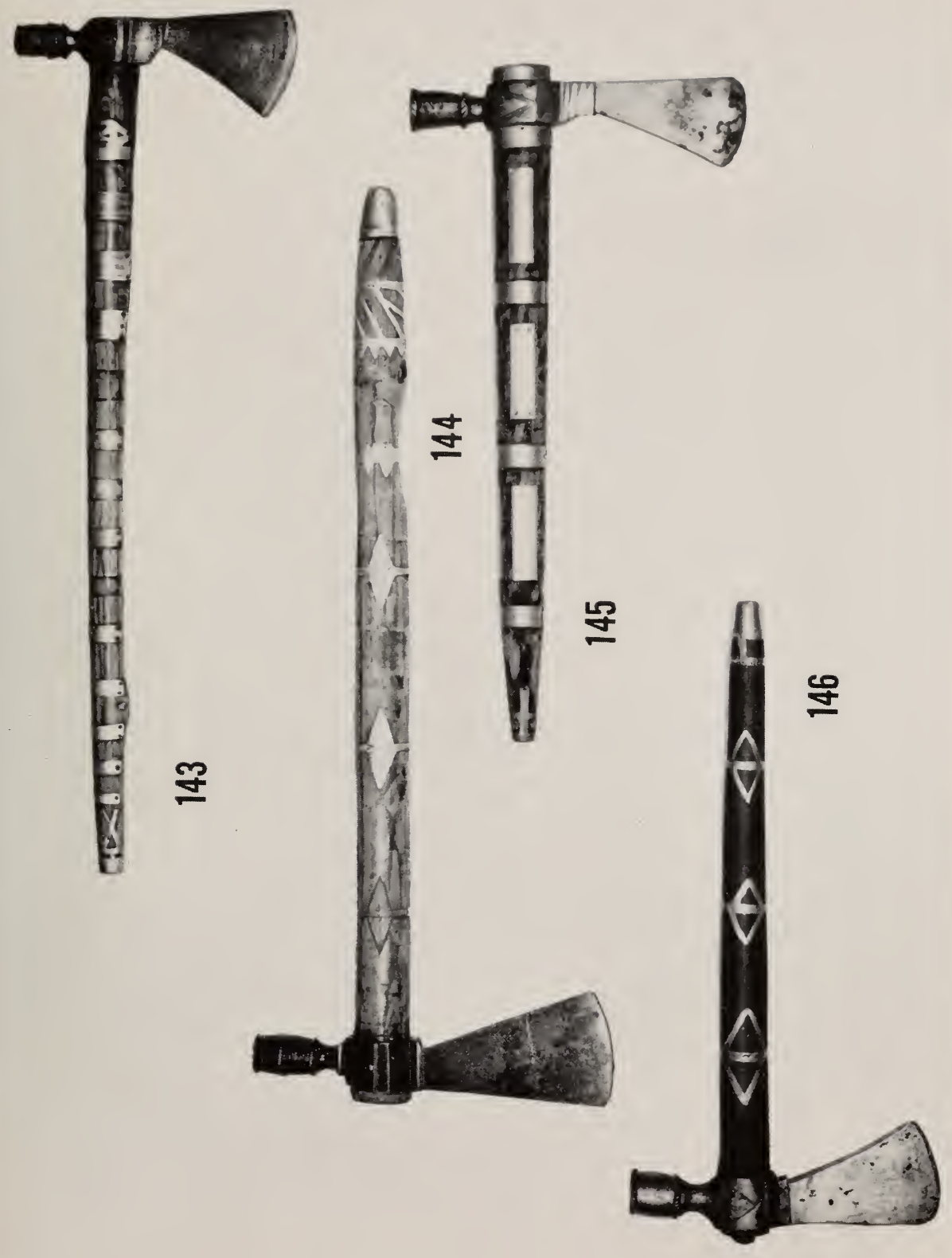



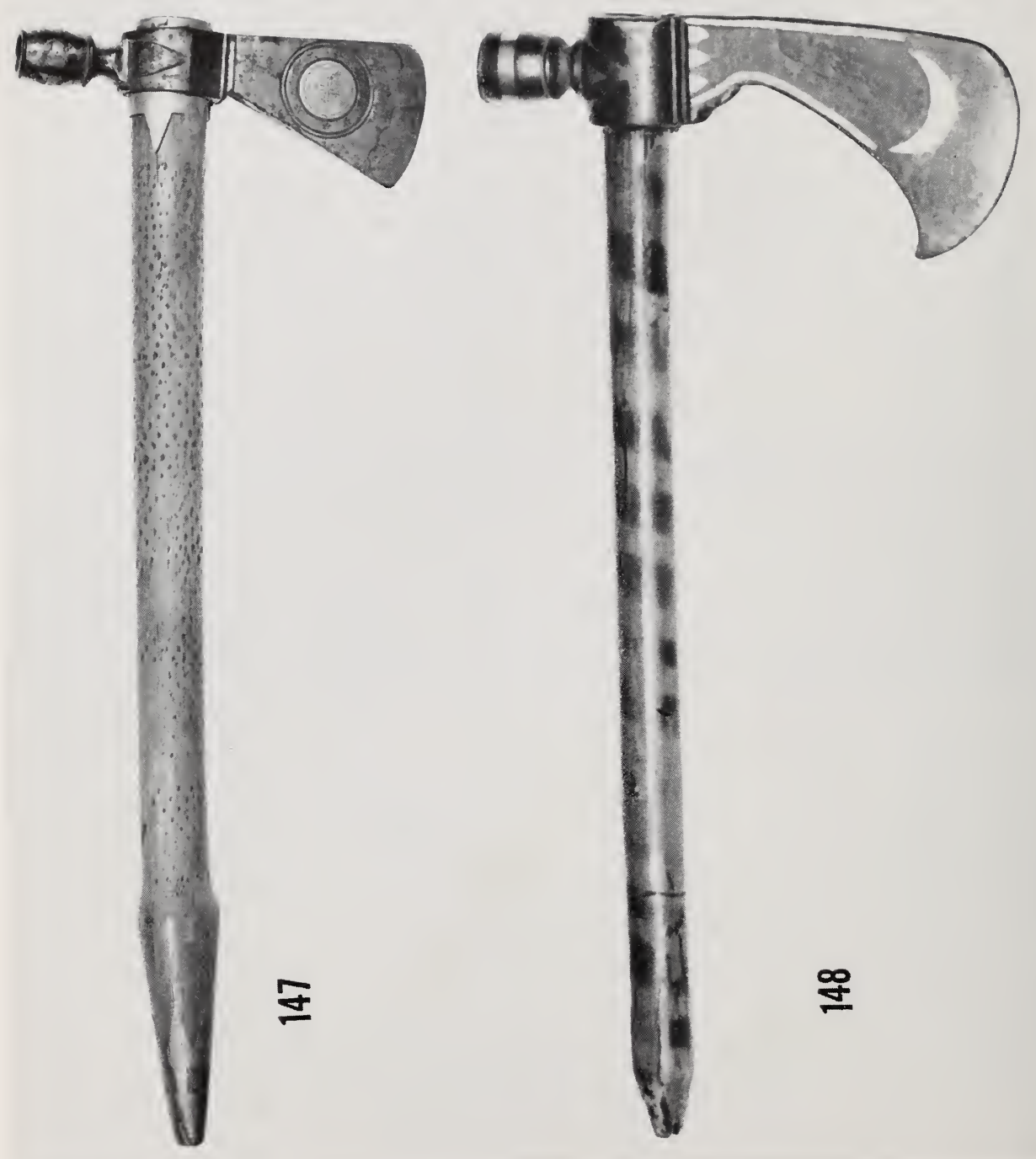


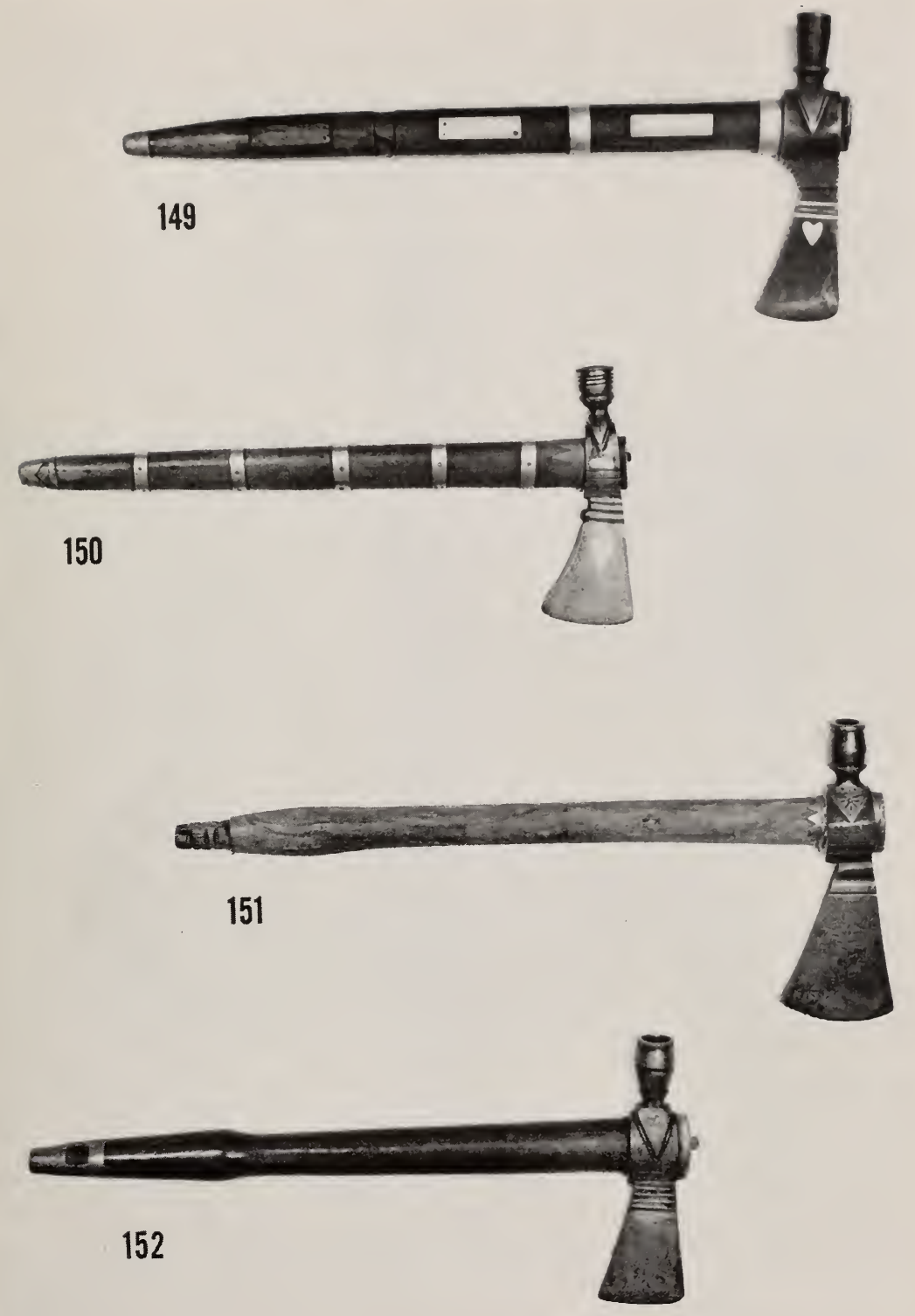




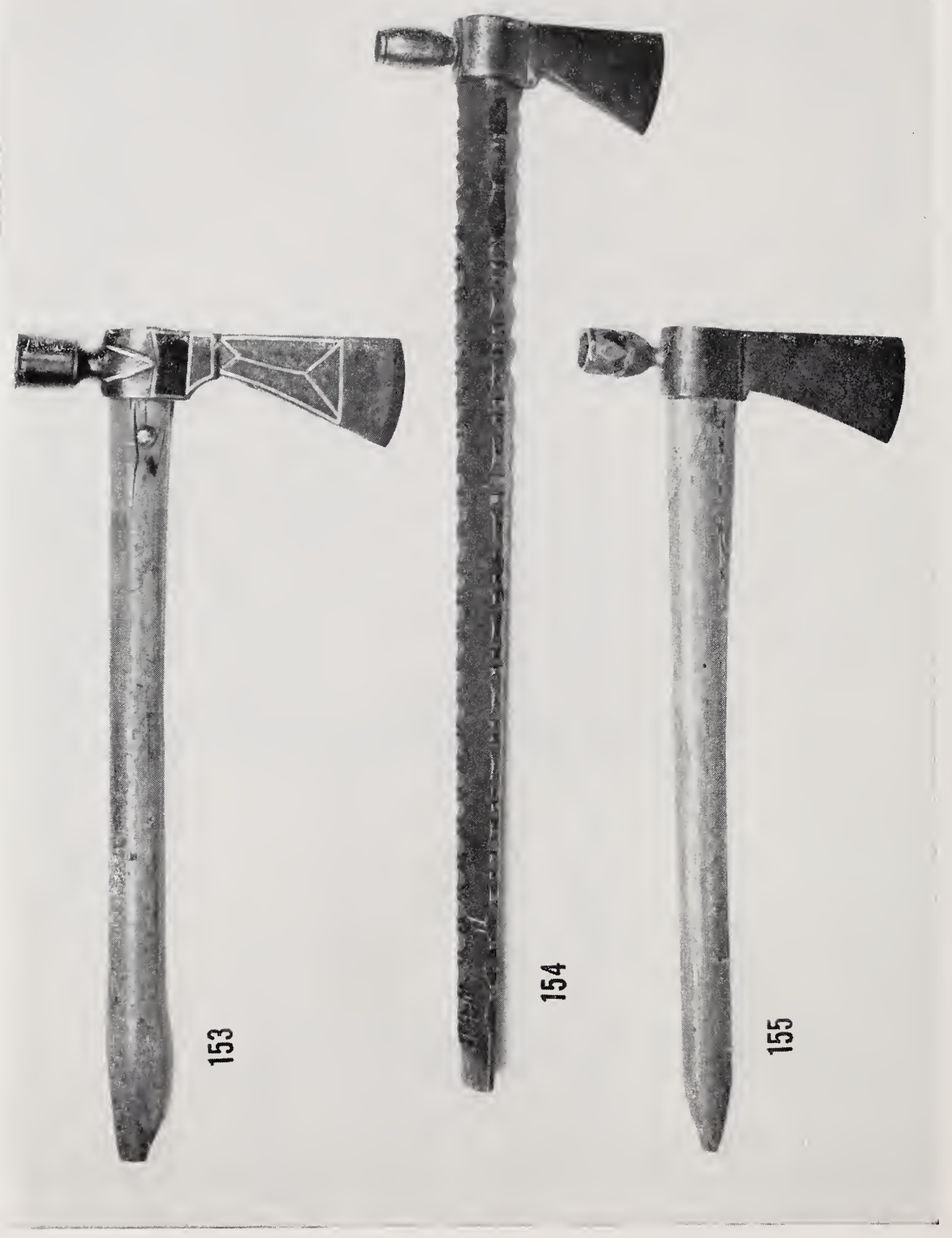



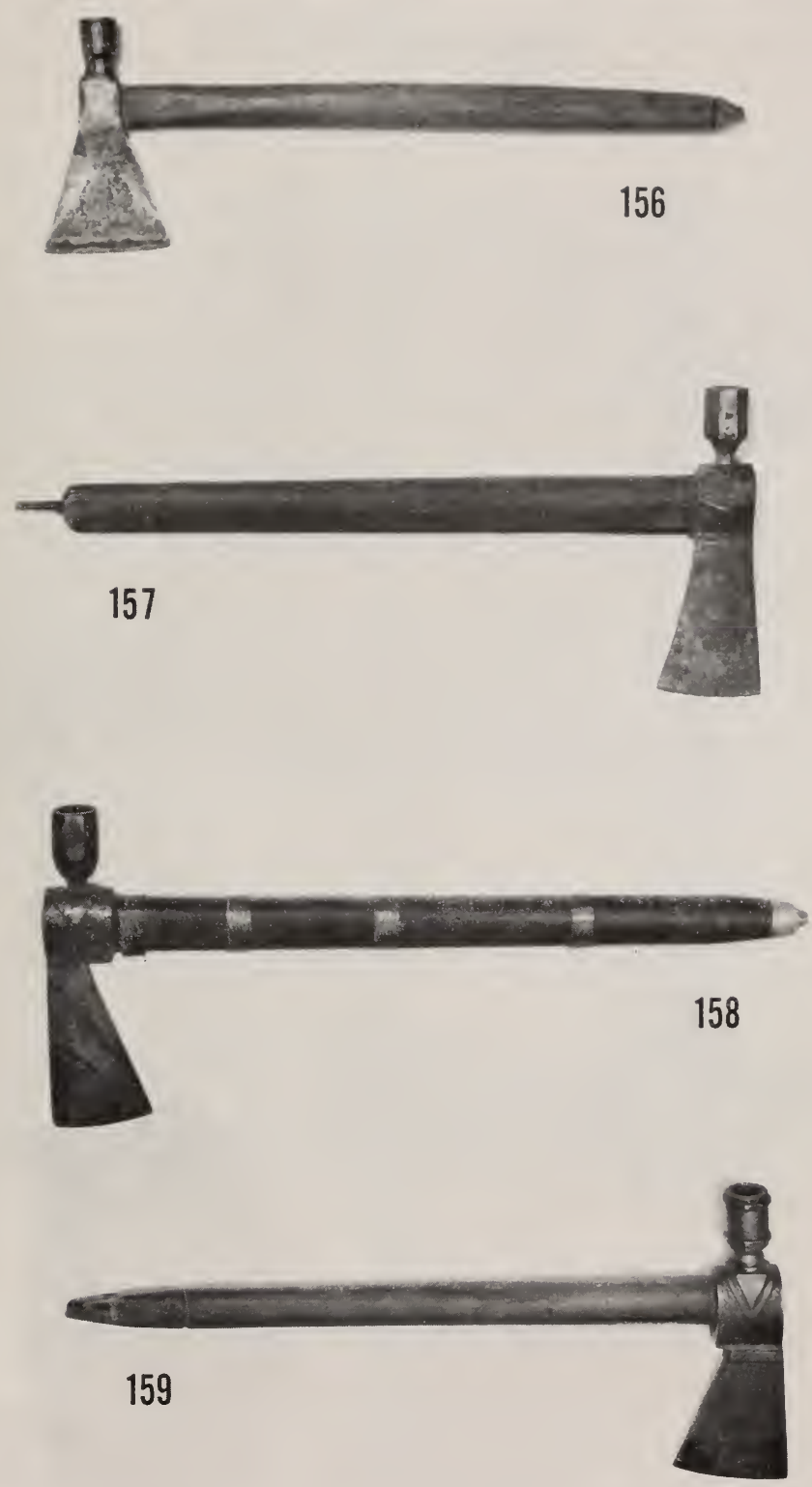


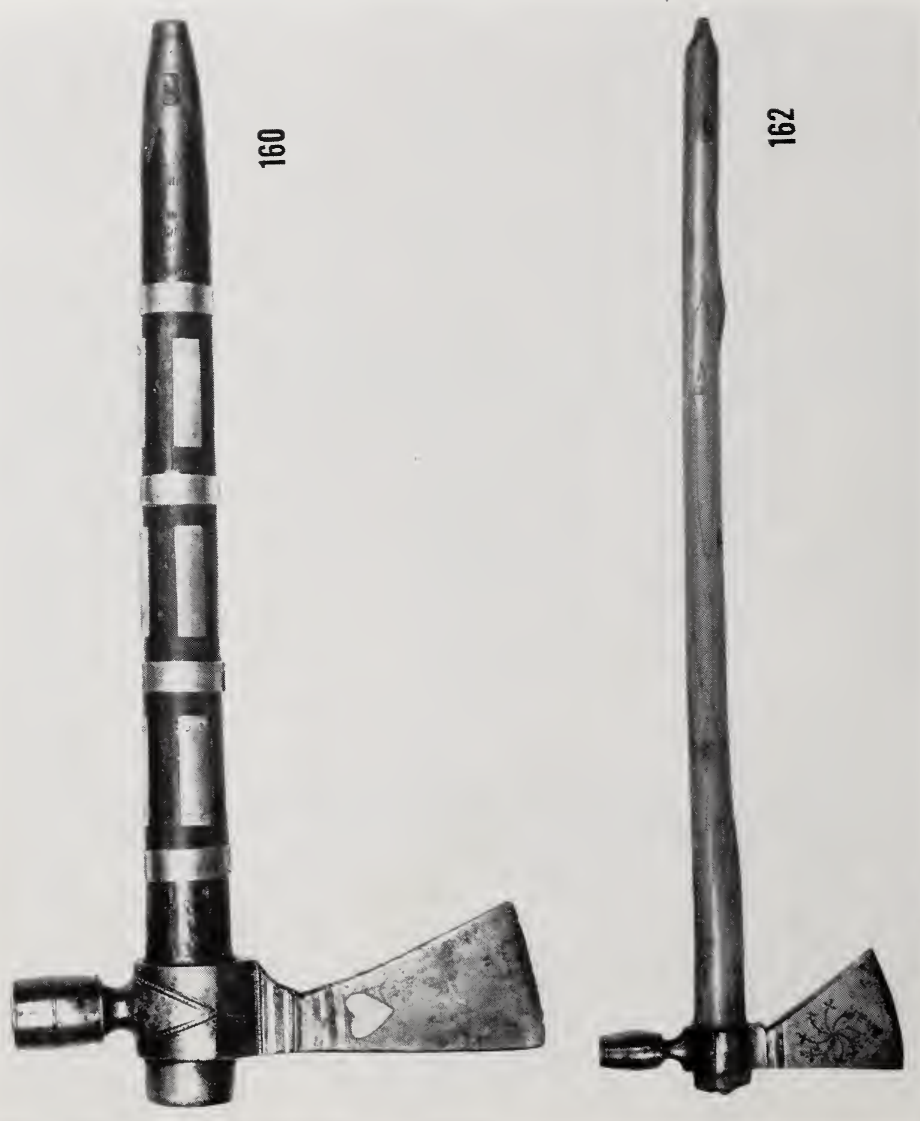




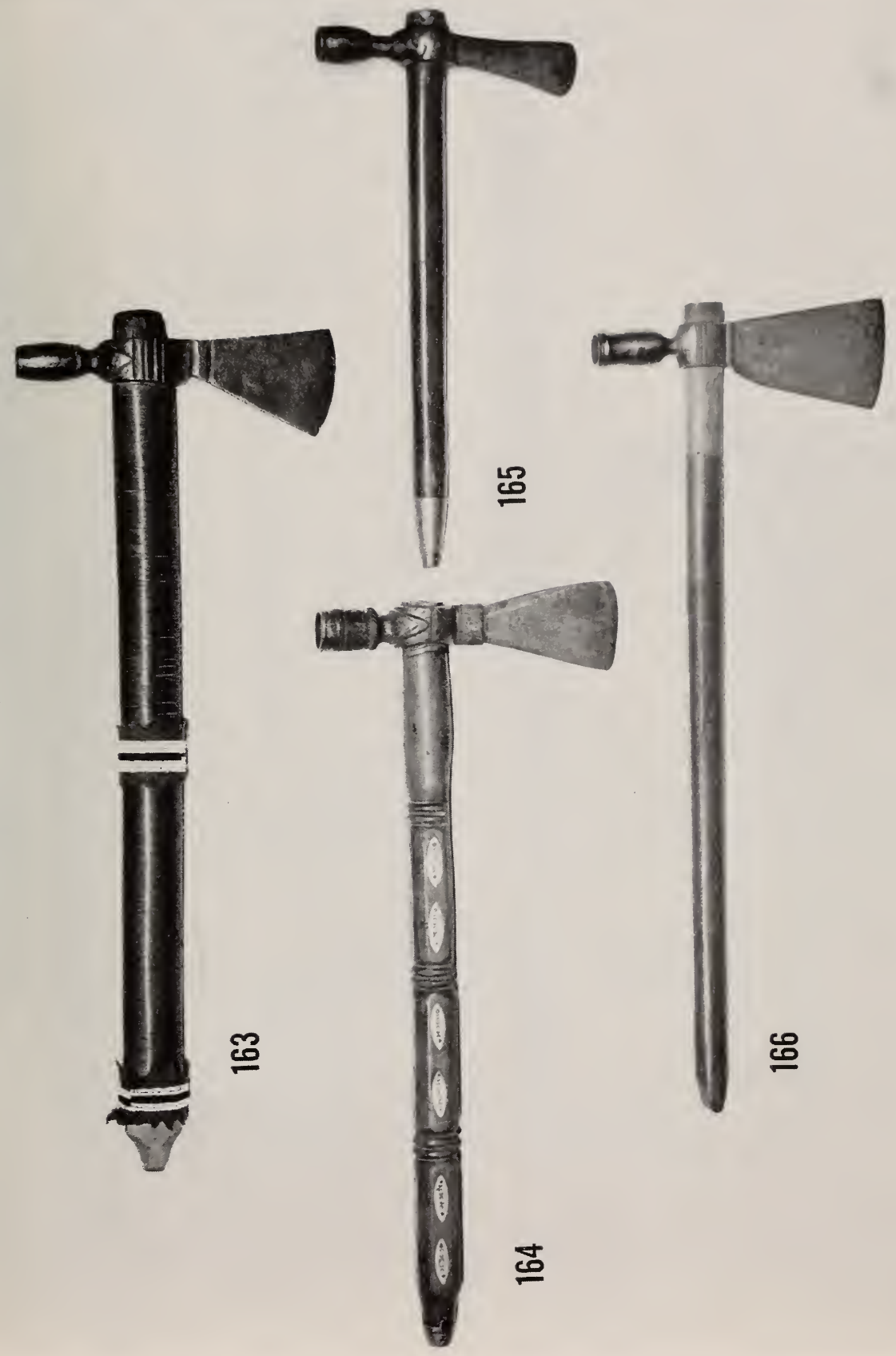




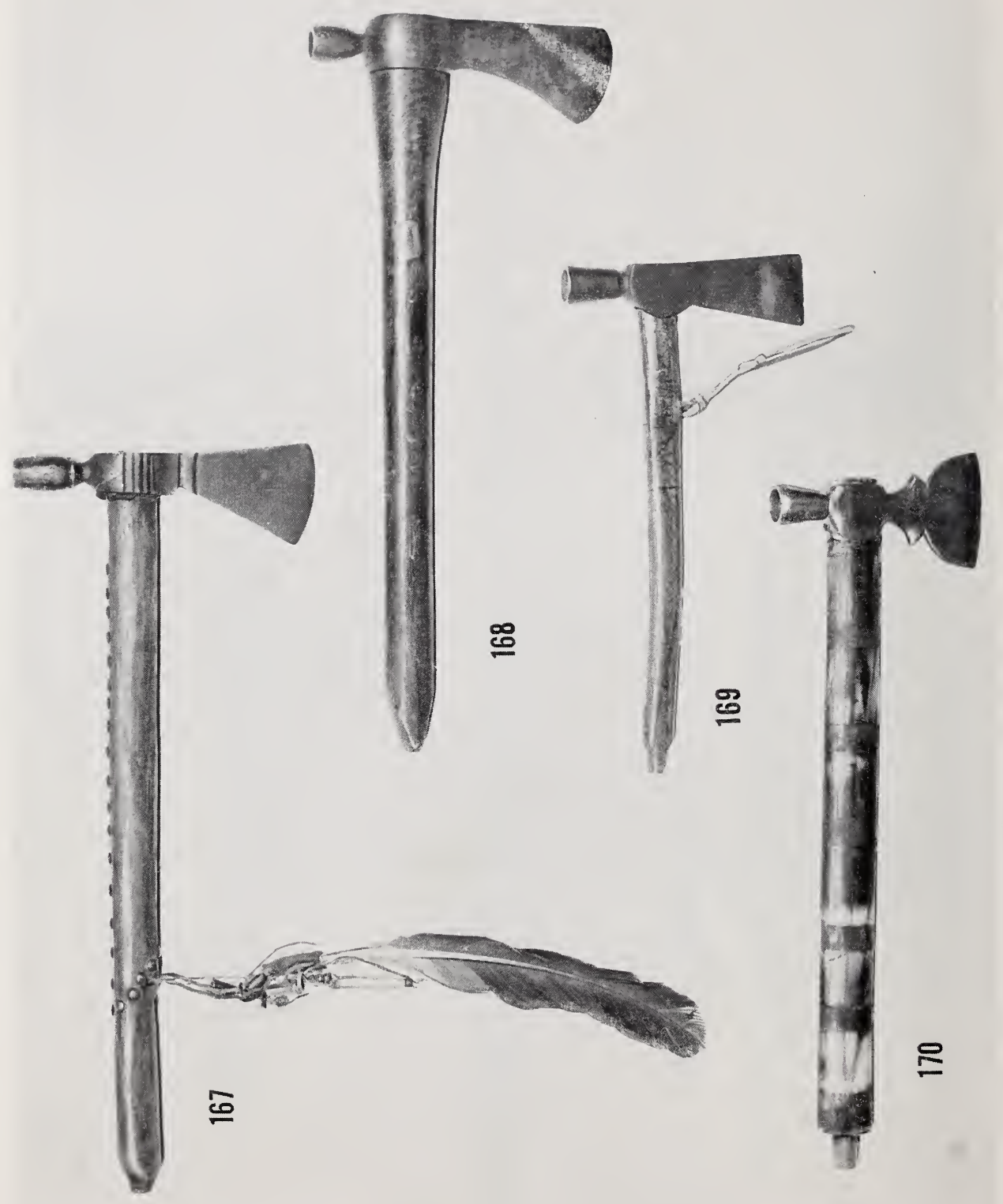




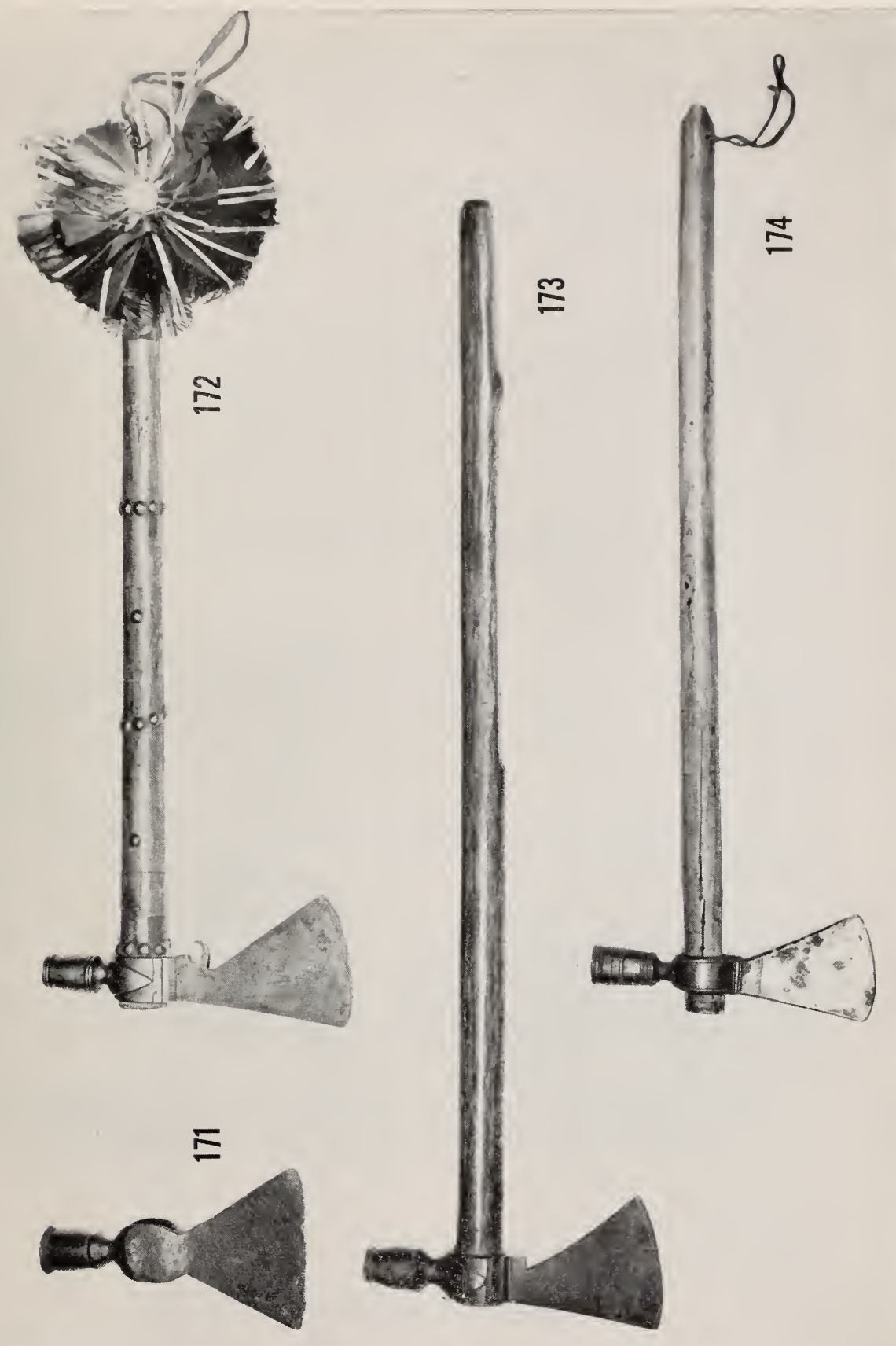



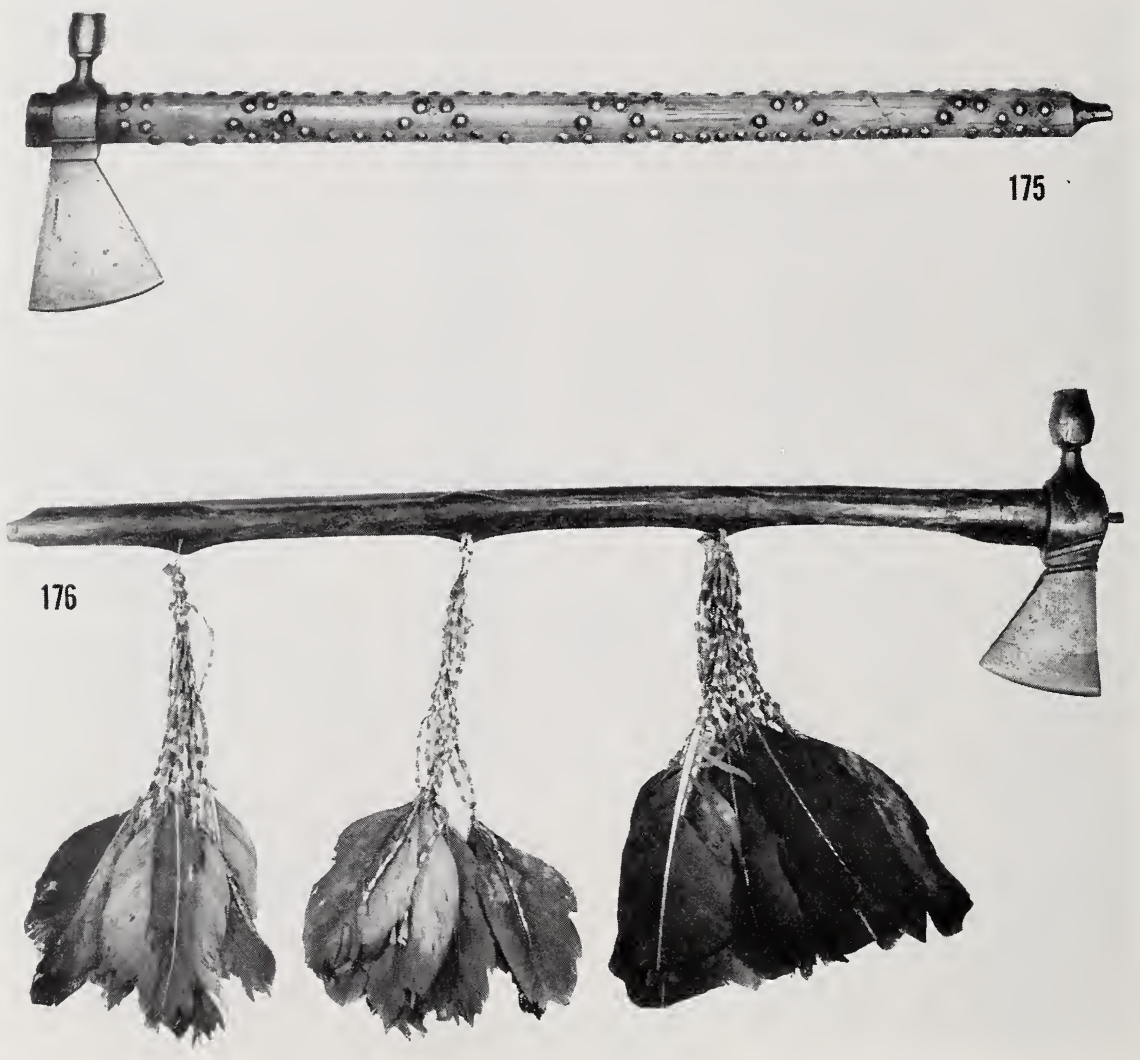


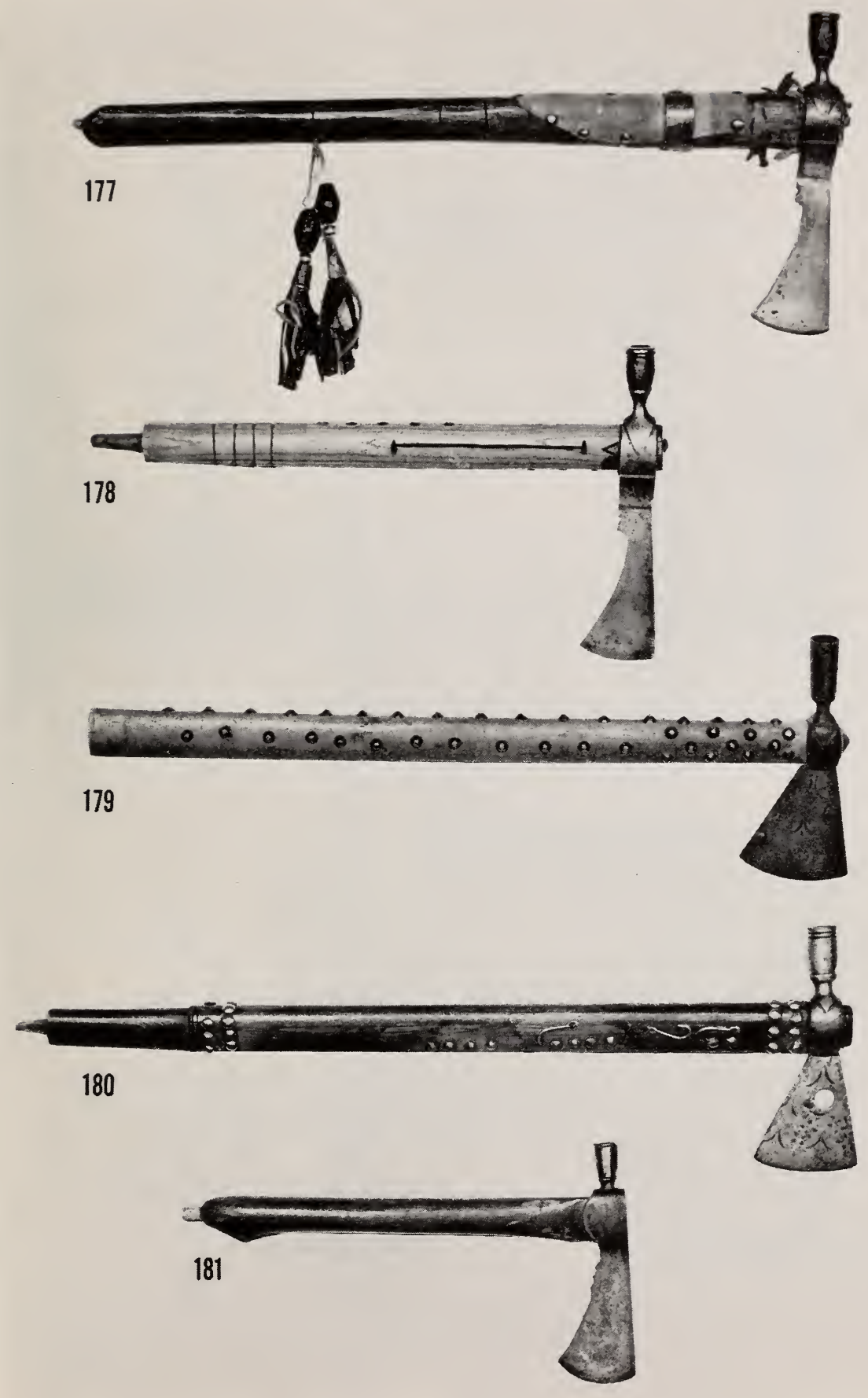




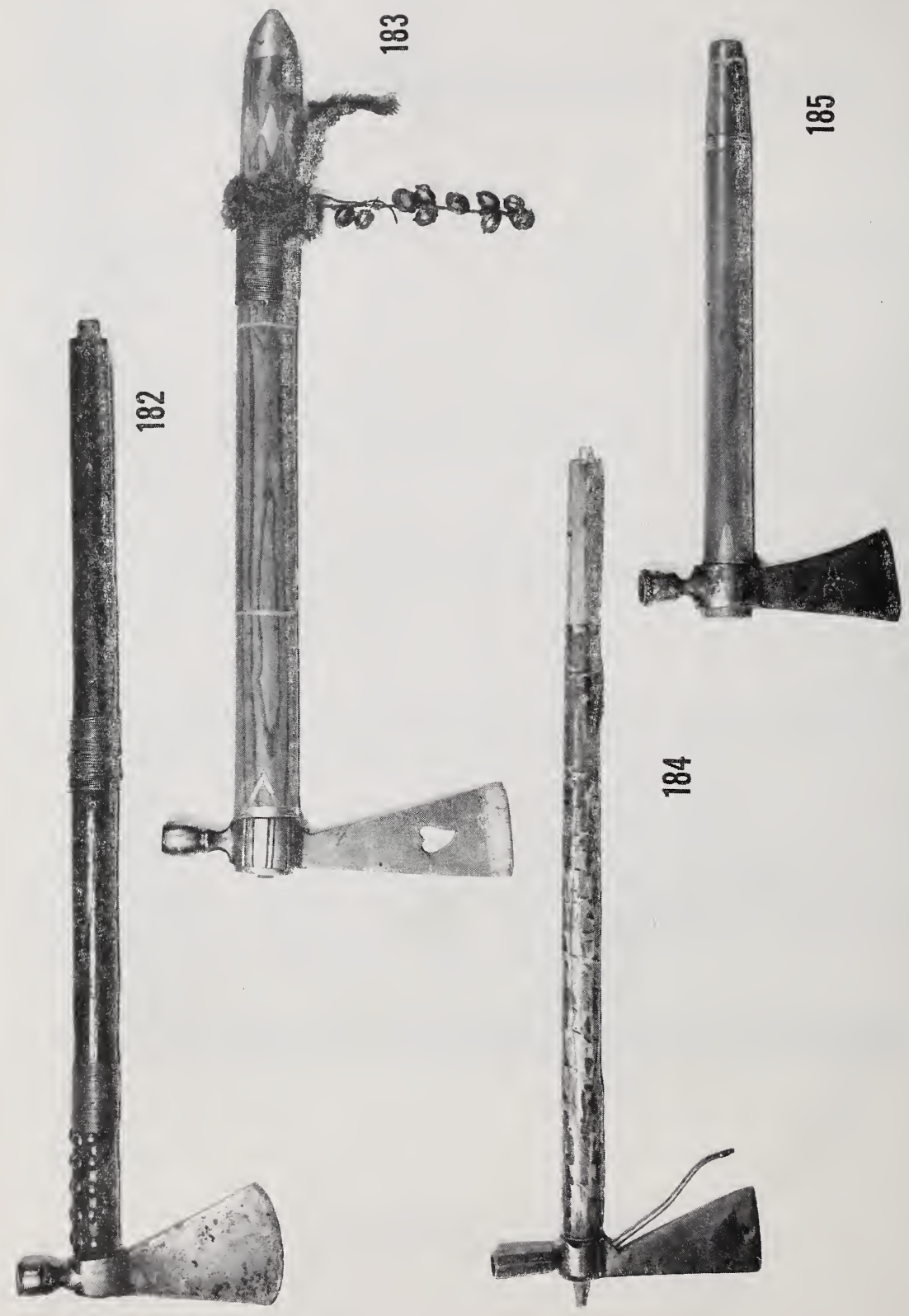



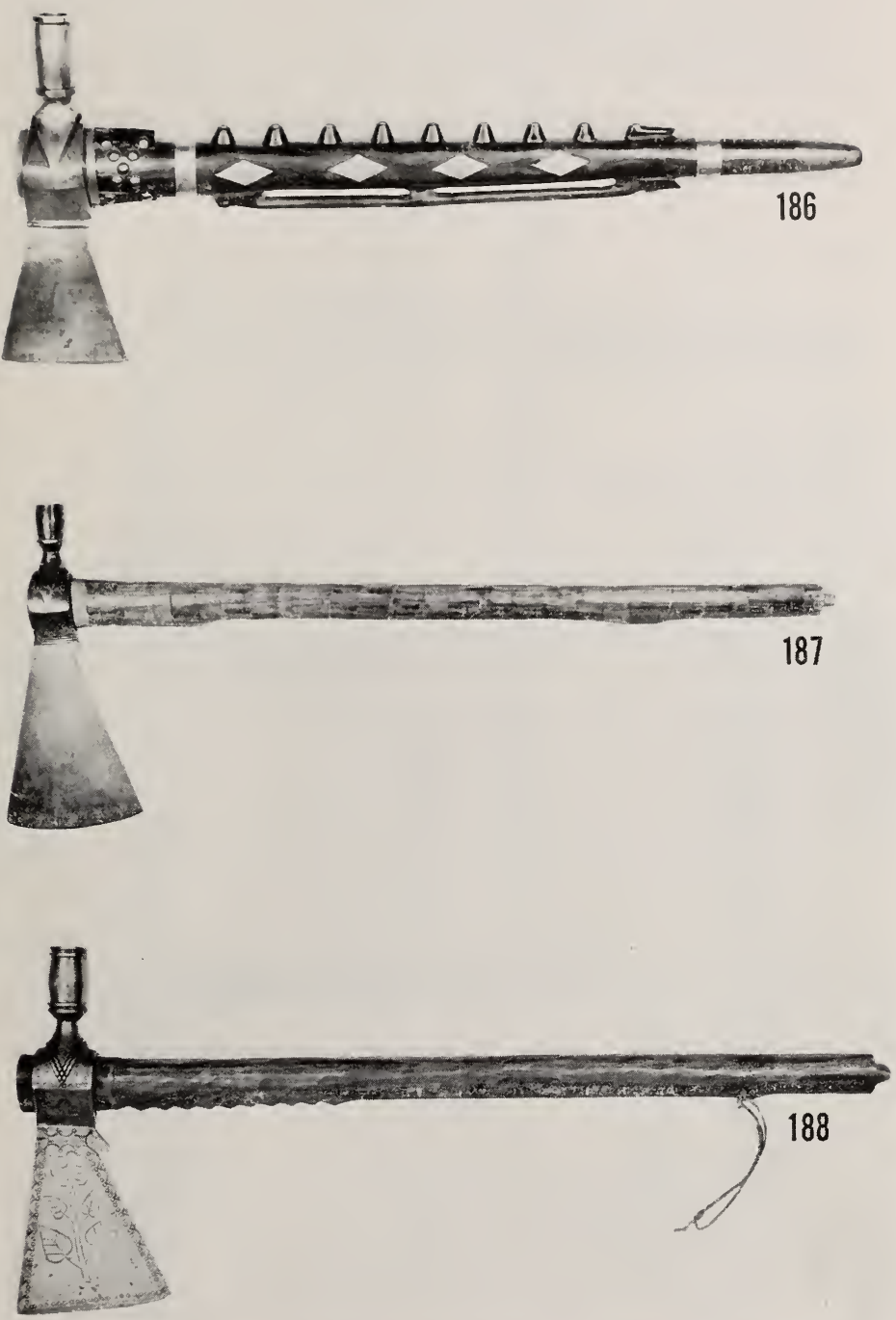


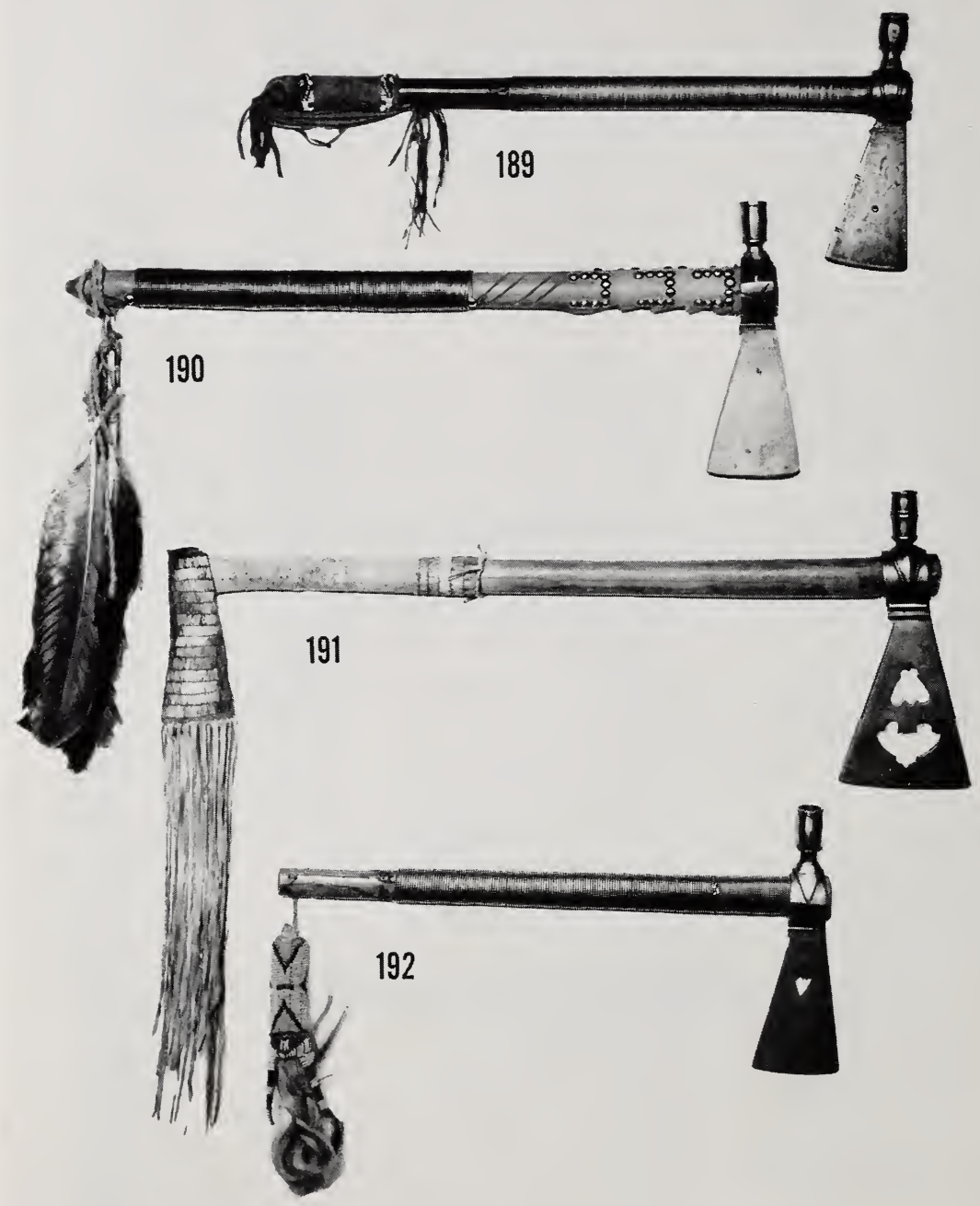




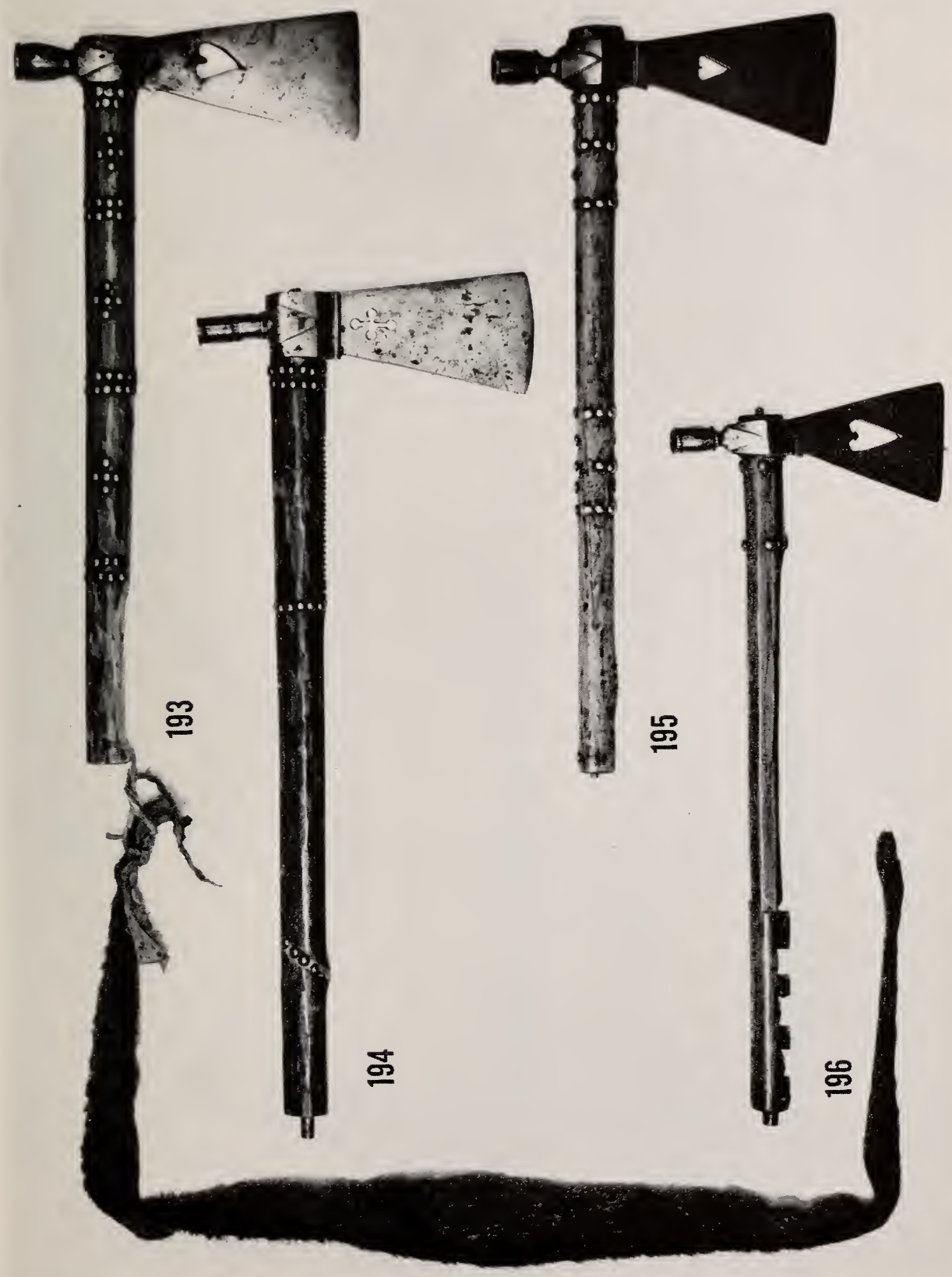




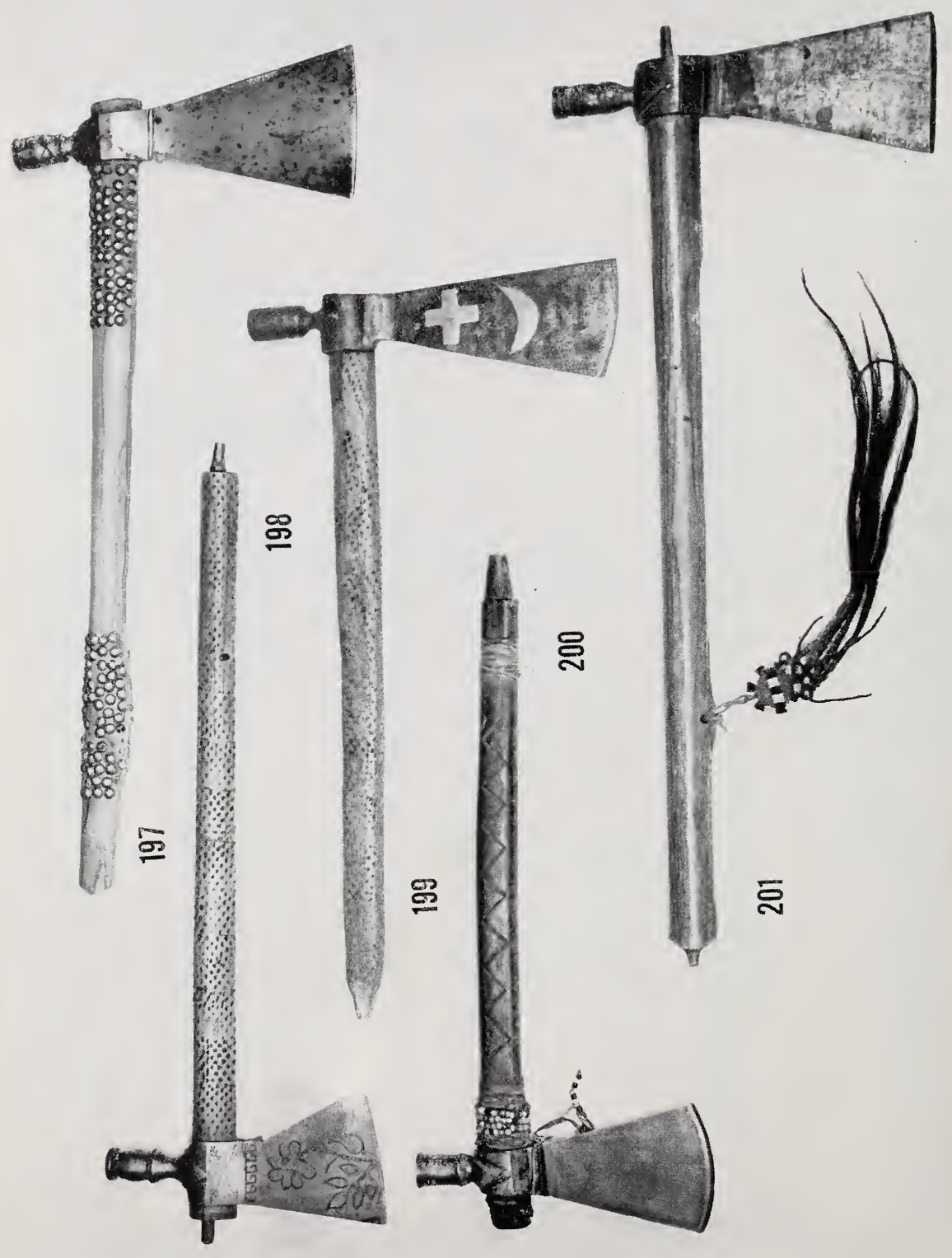



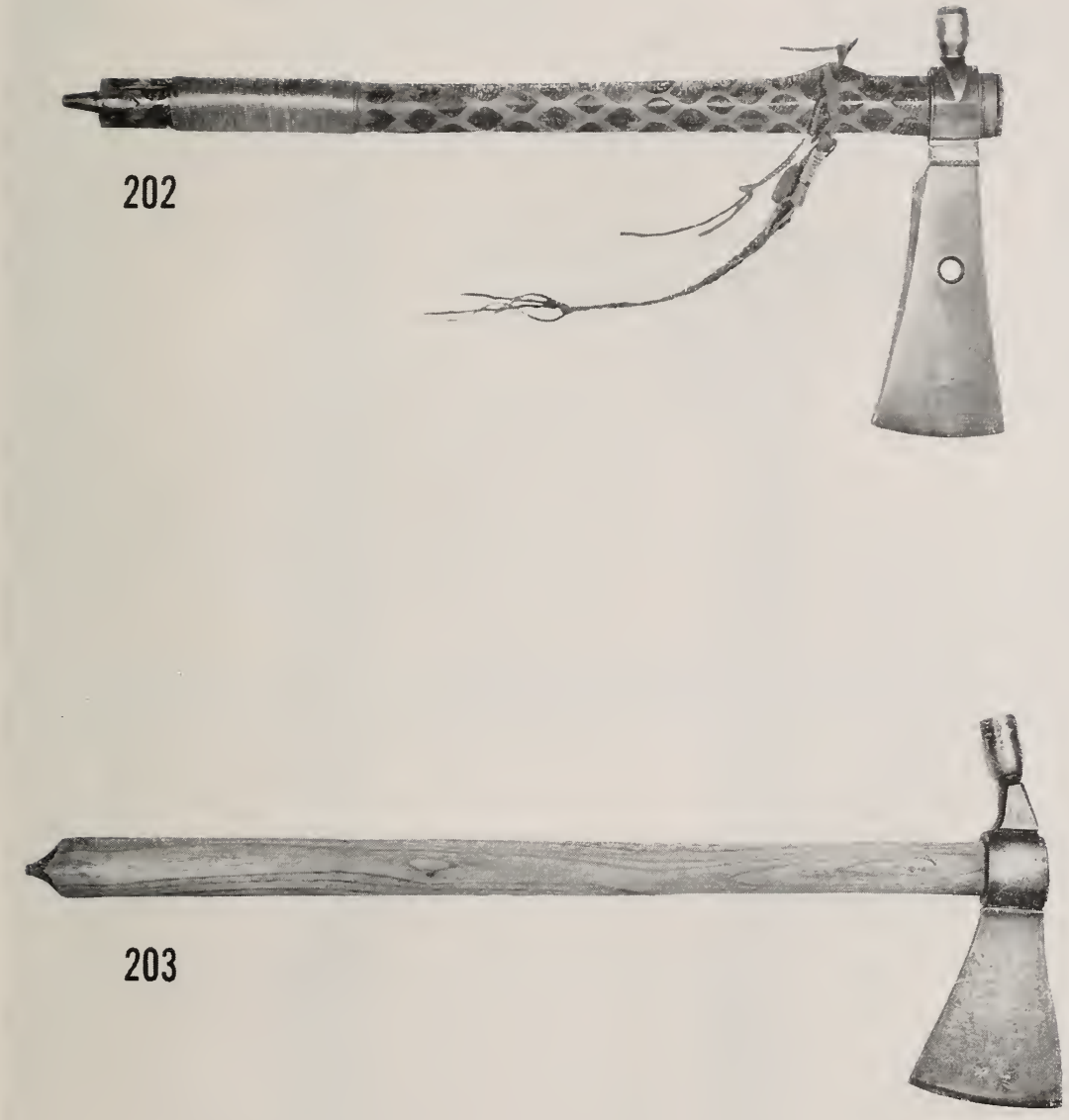


$$
\text { TrT }
$$



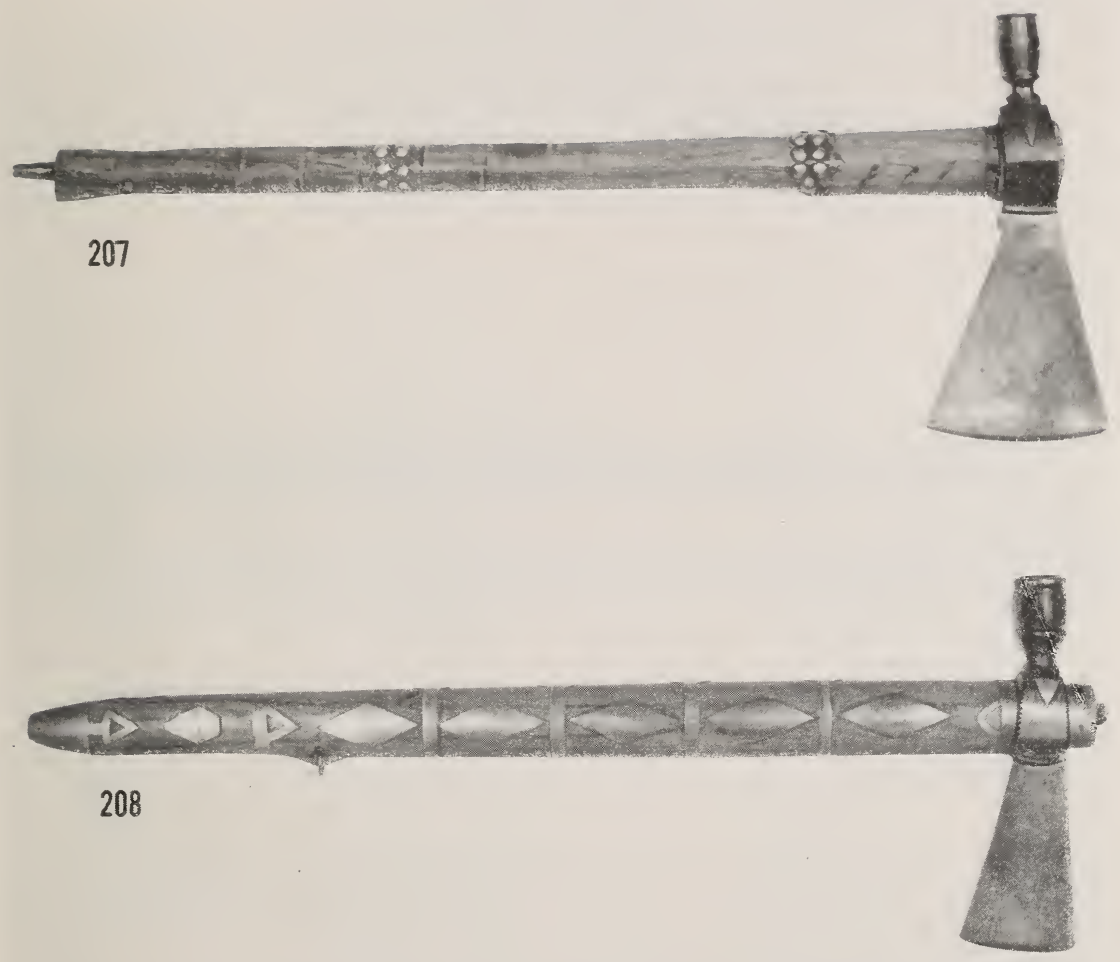

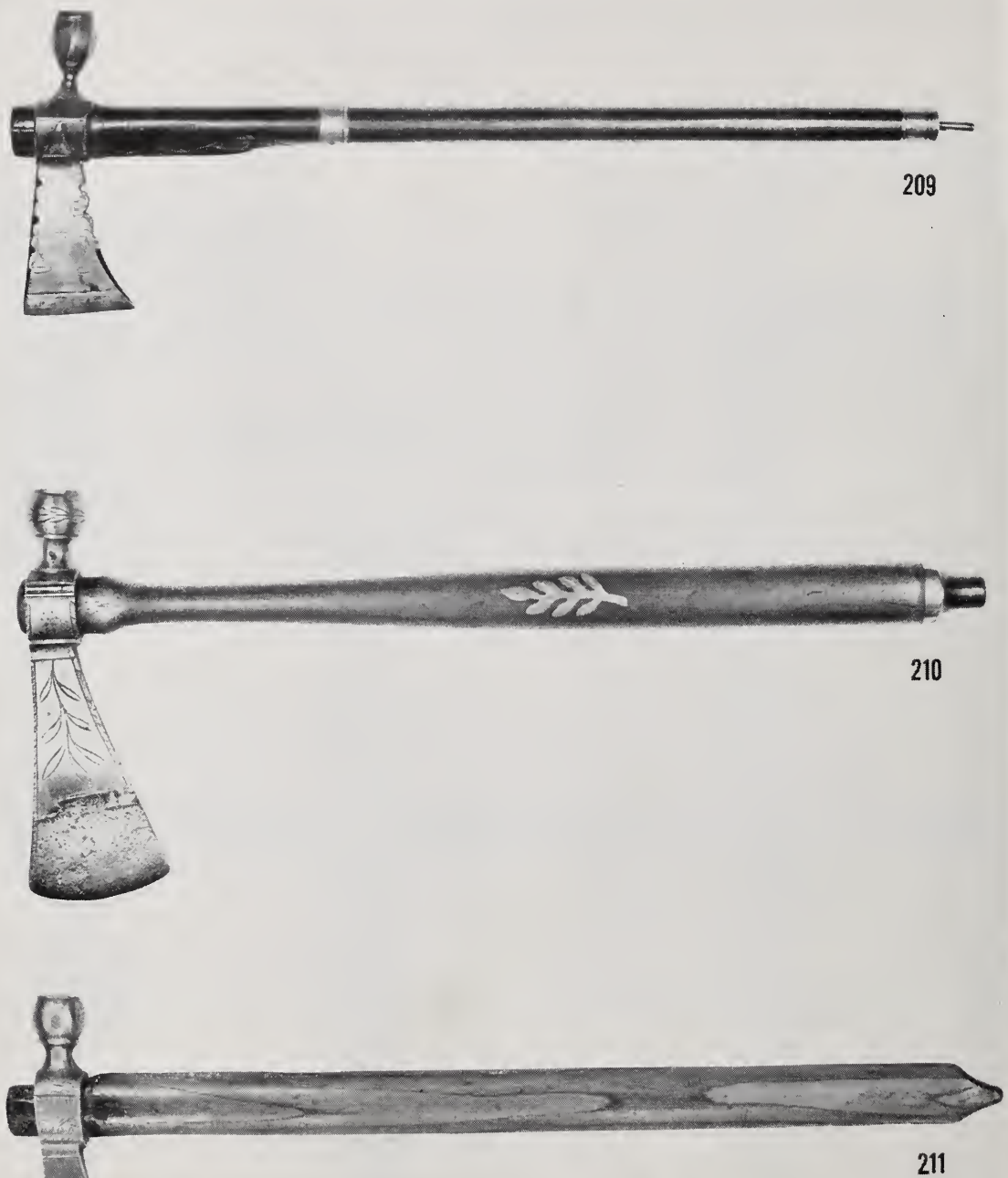

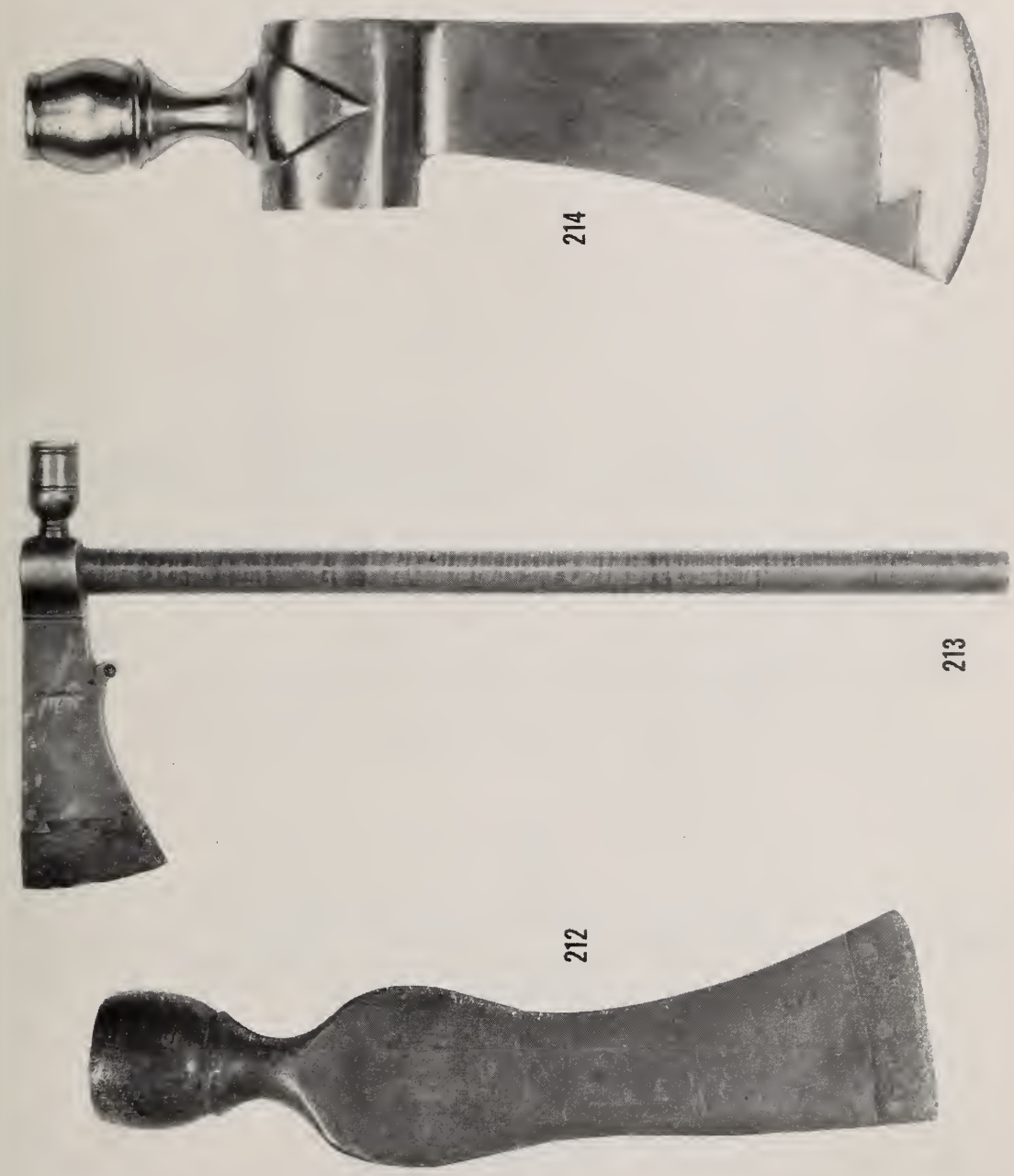

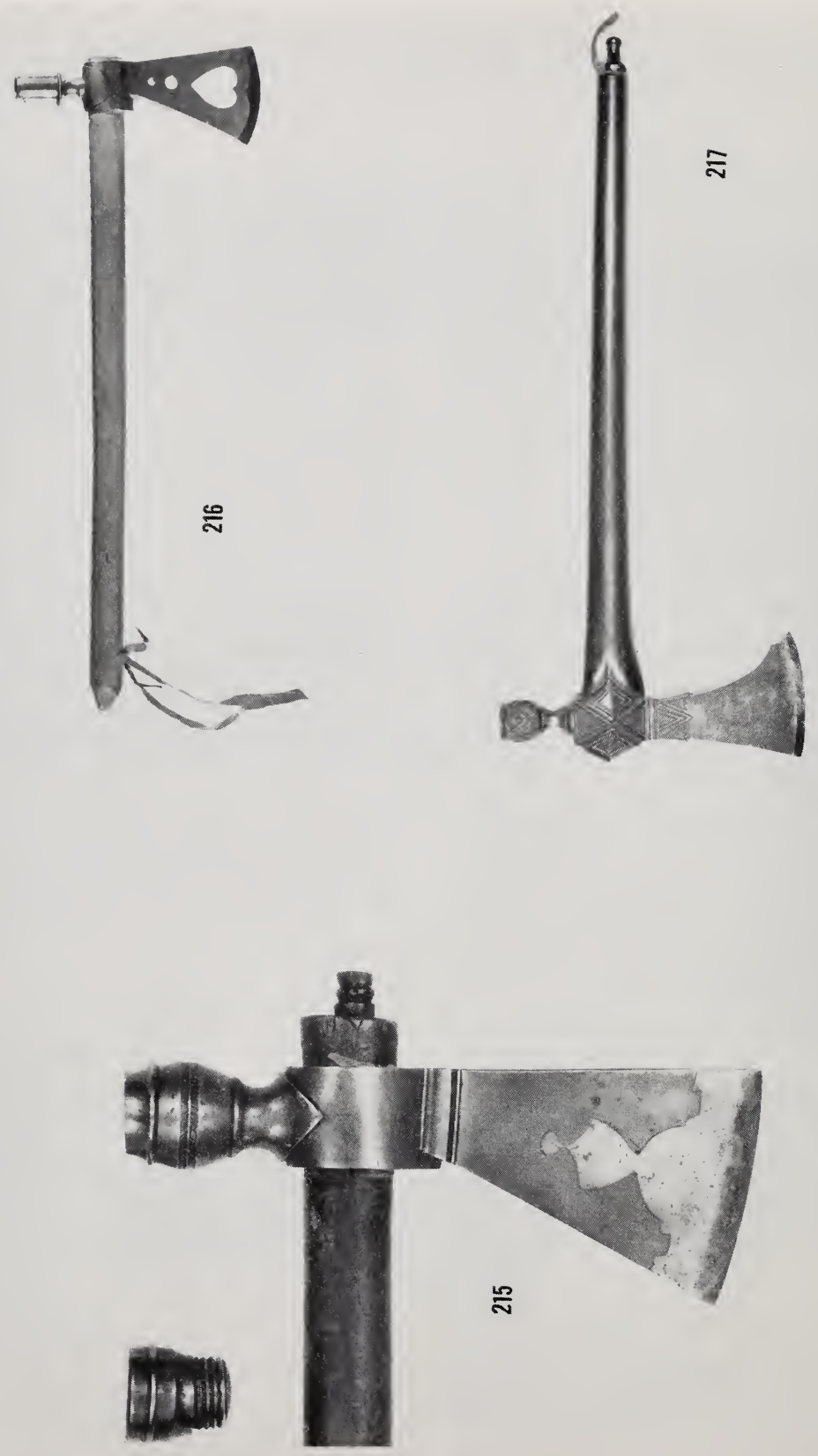

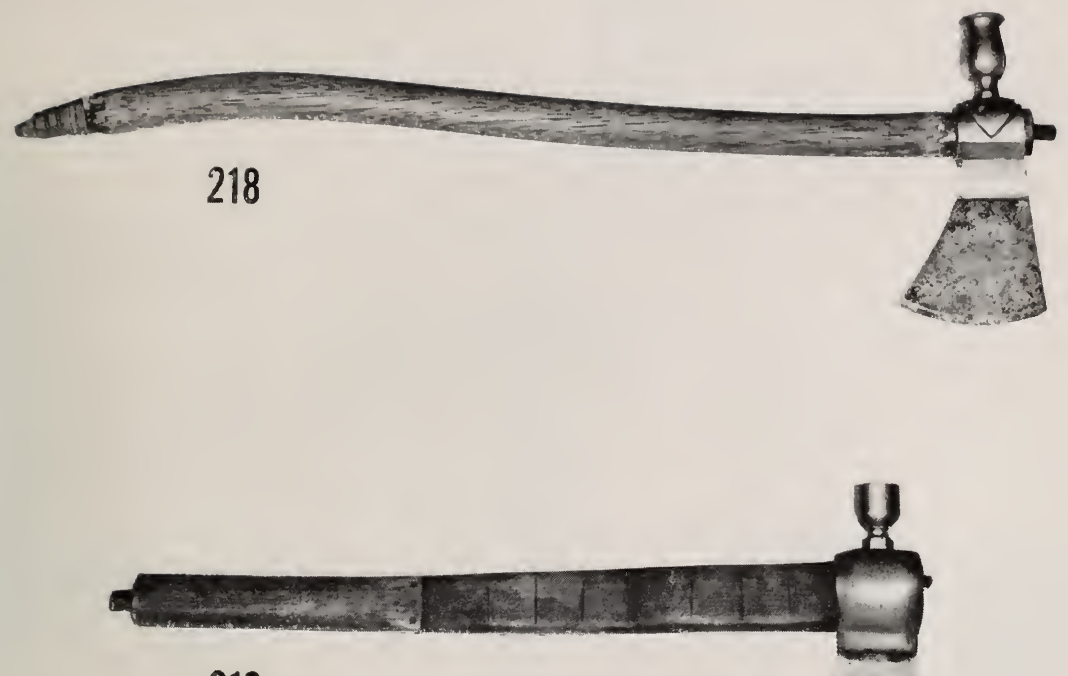

219

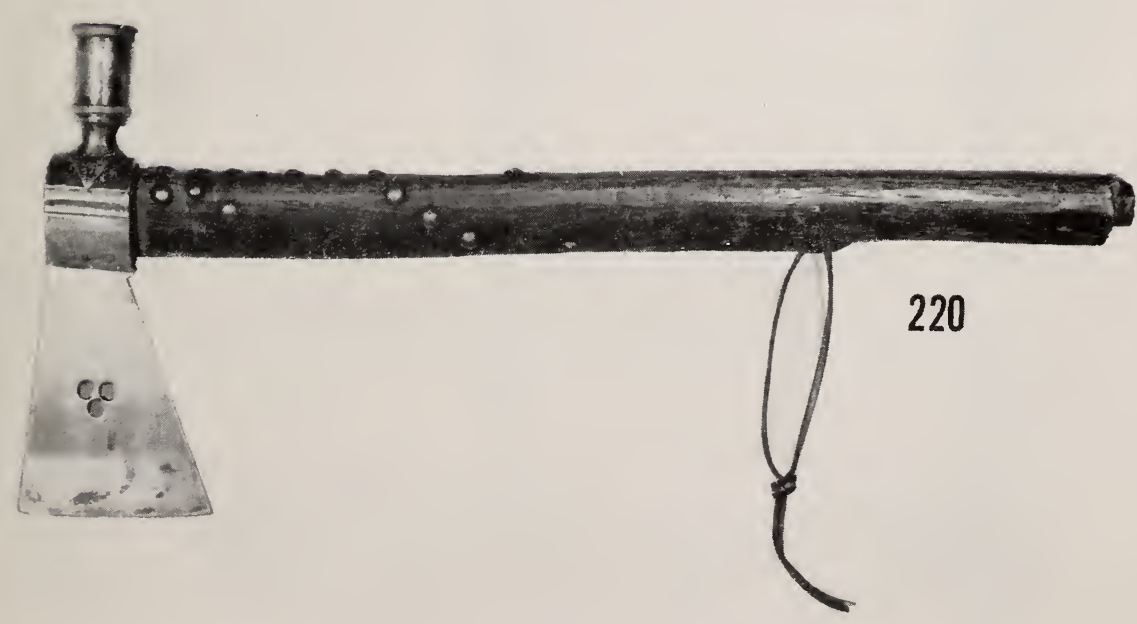



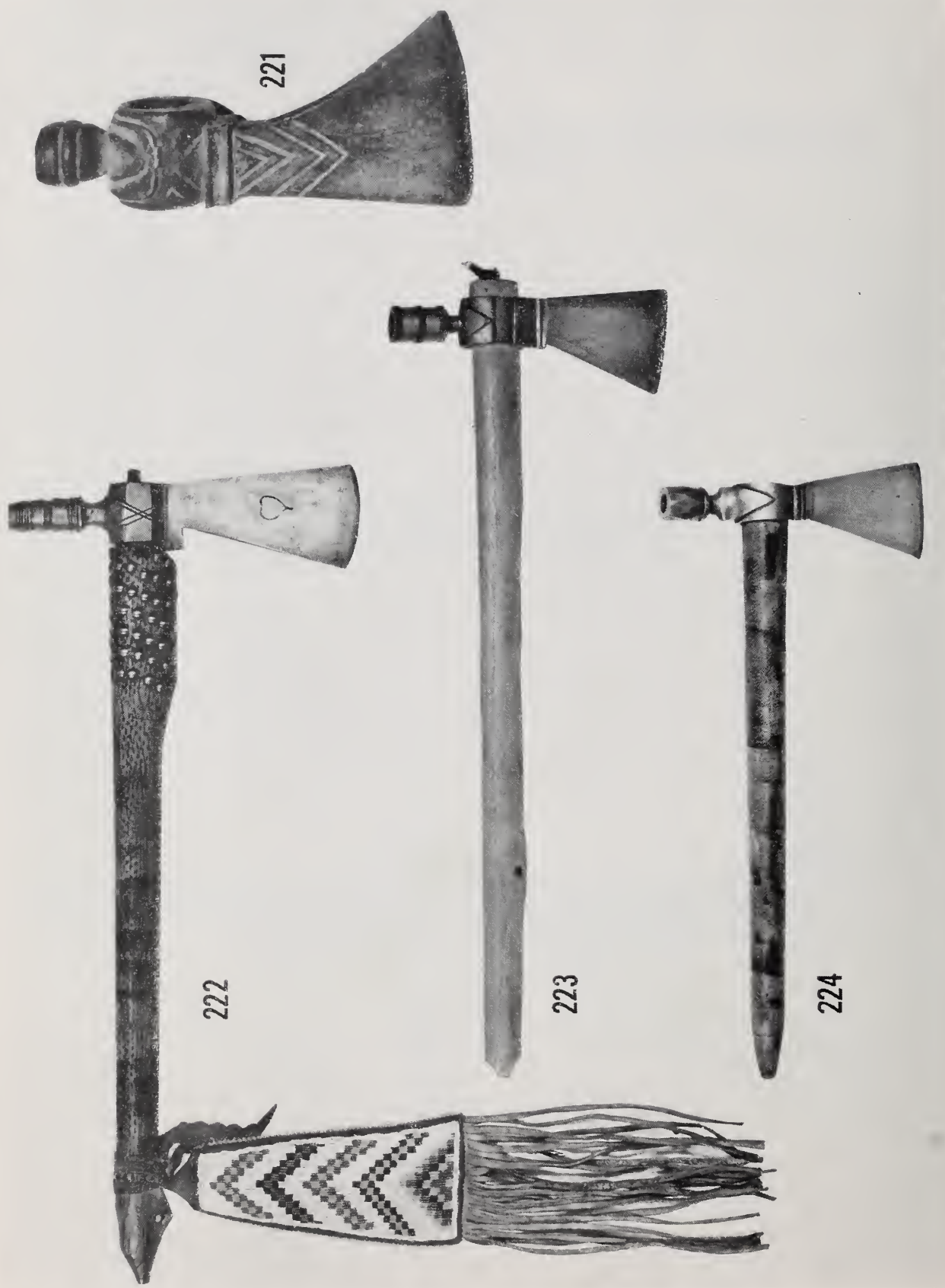

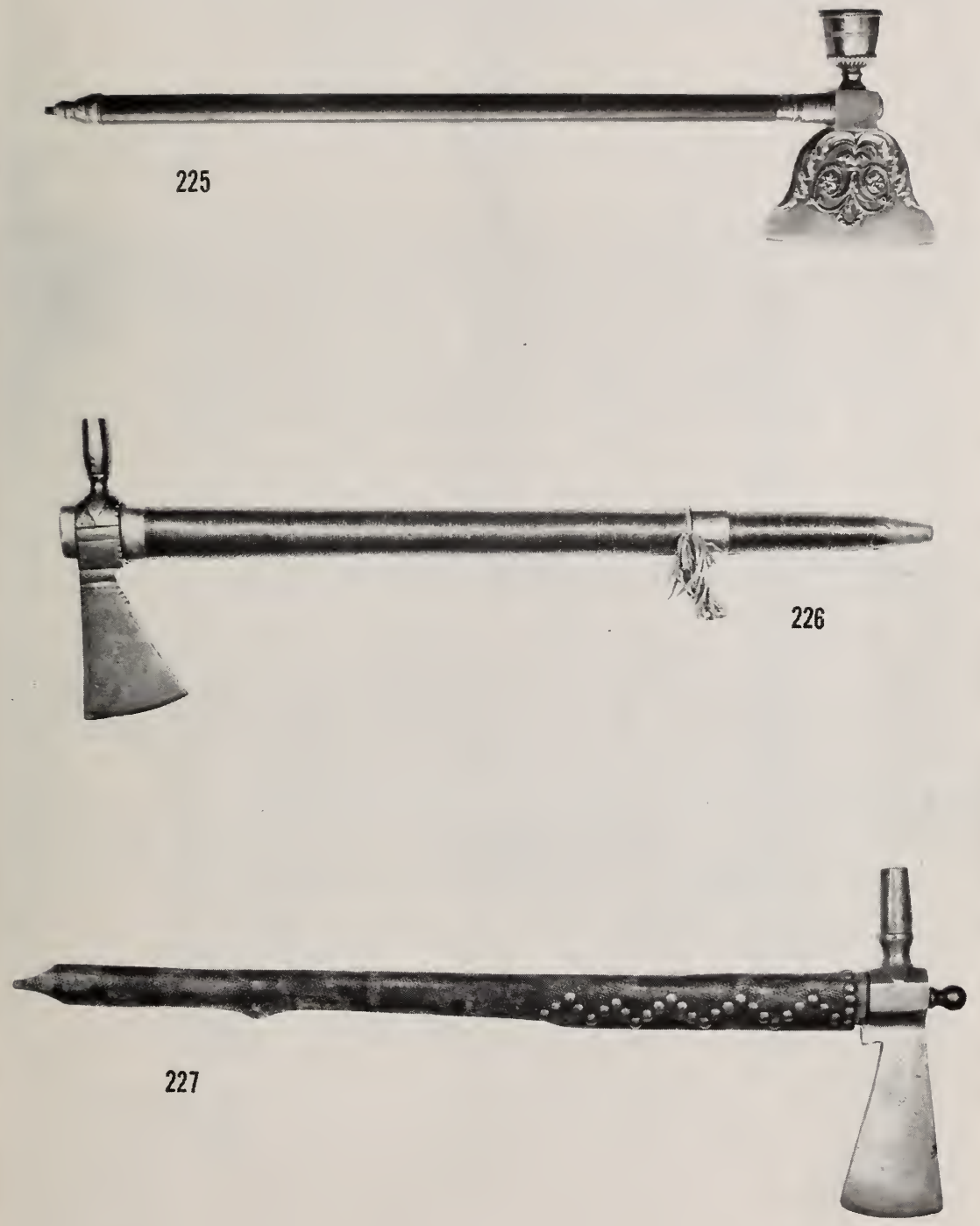


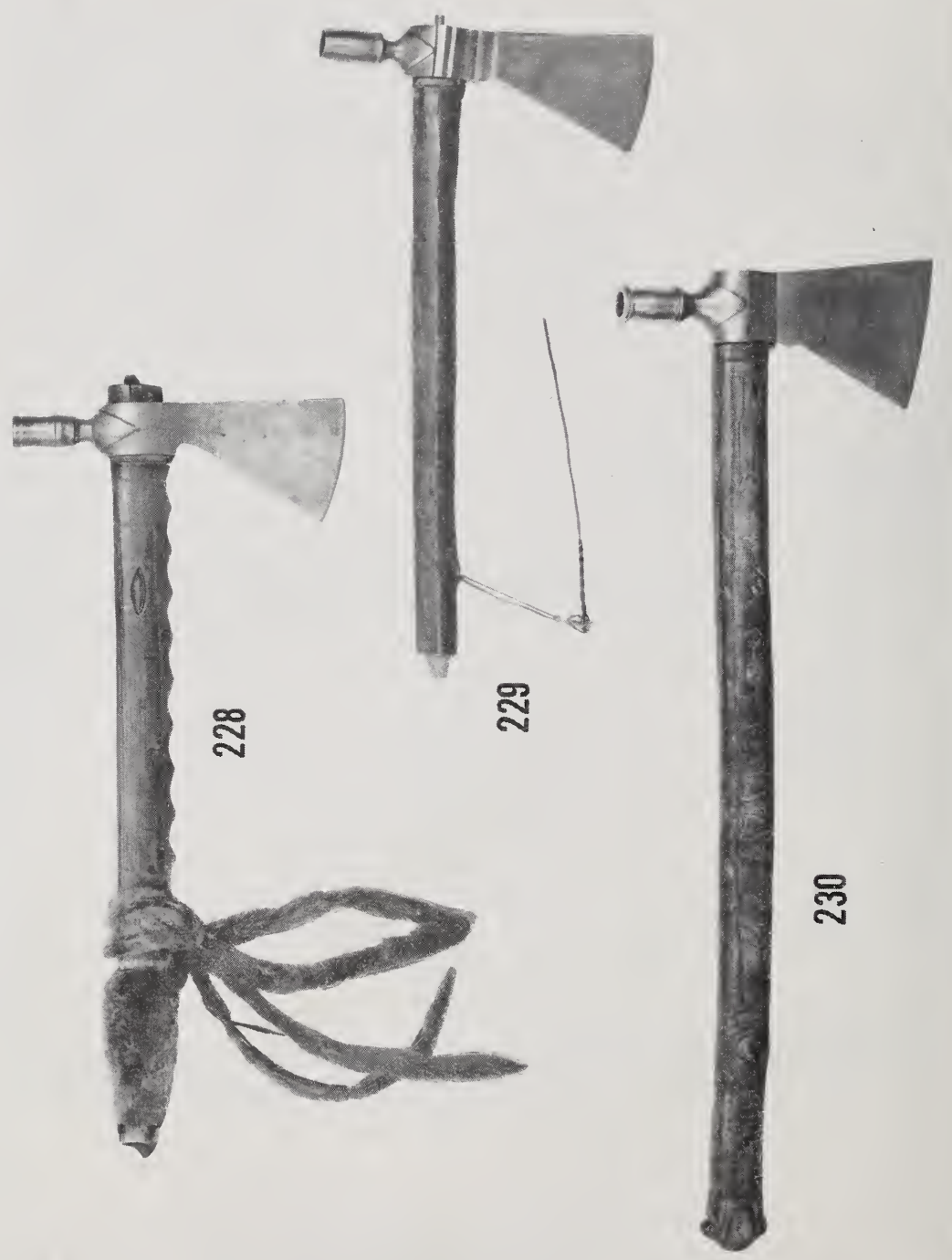




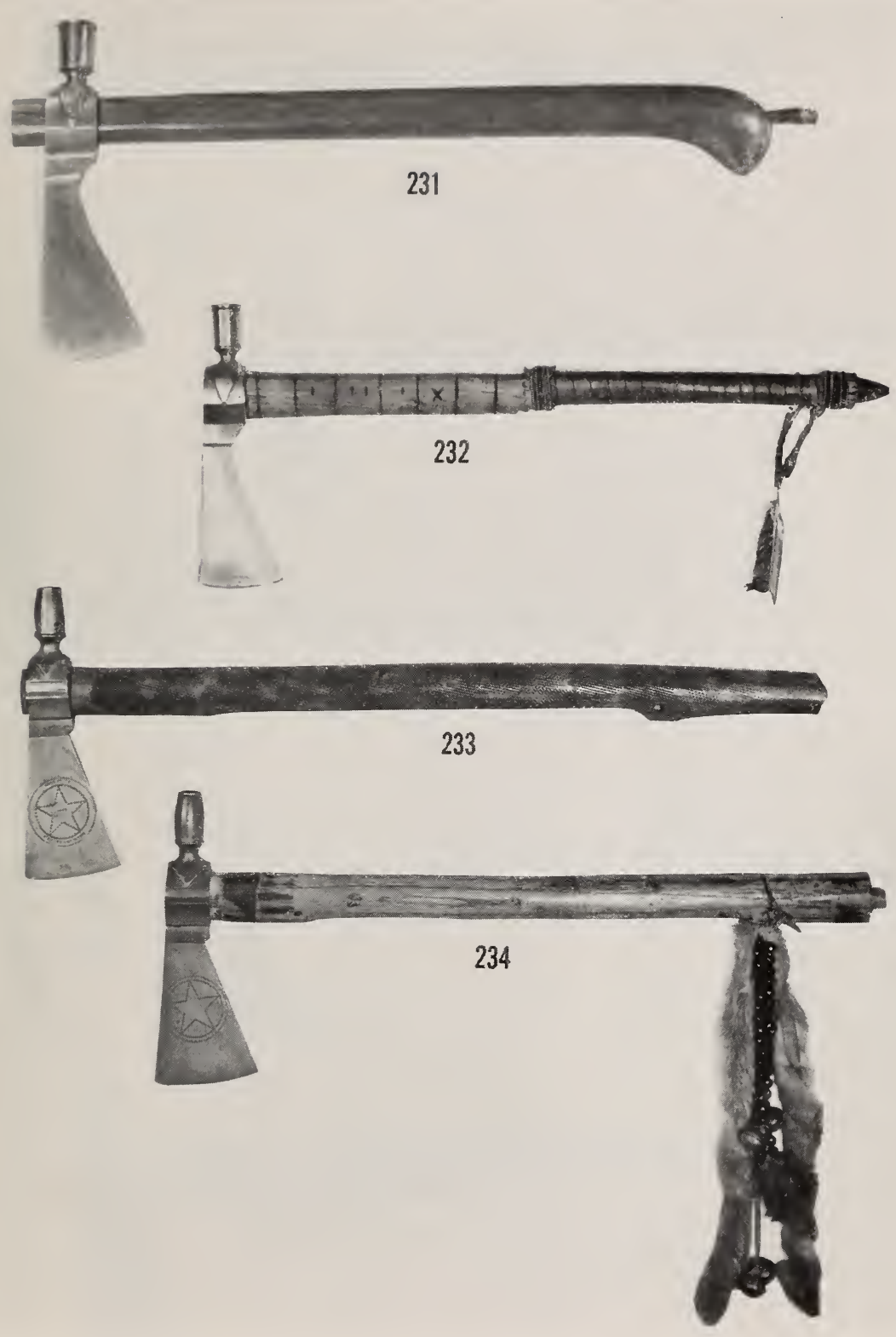




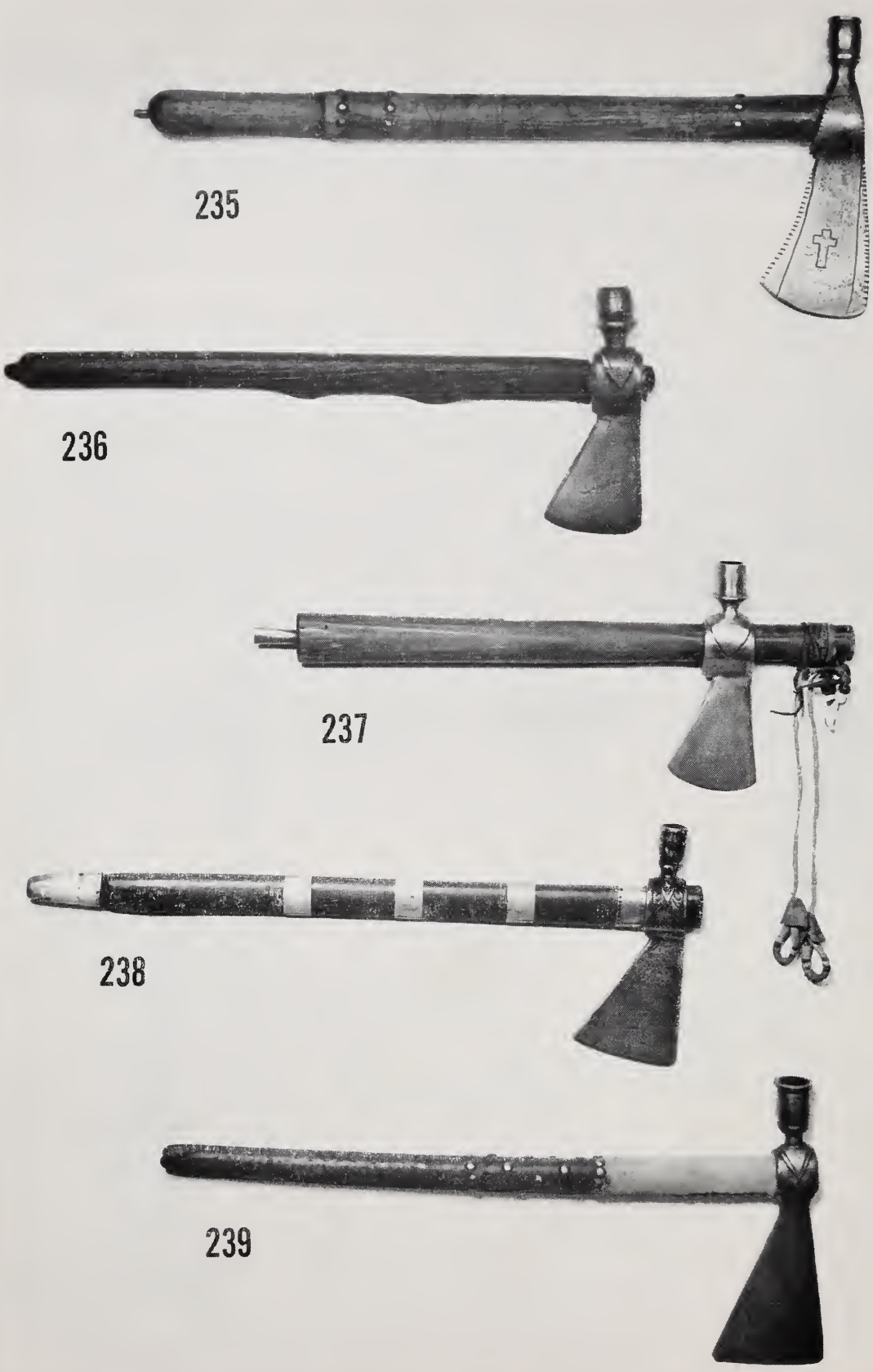




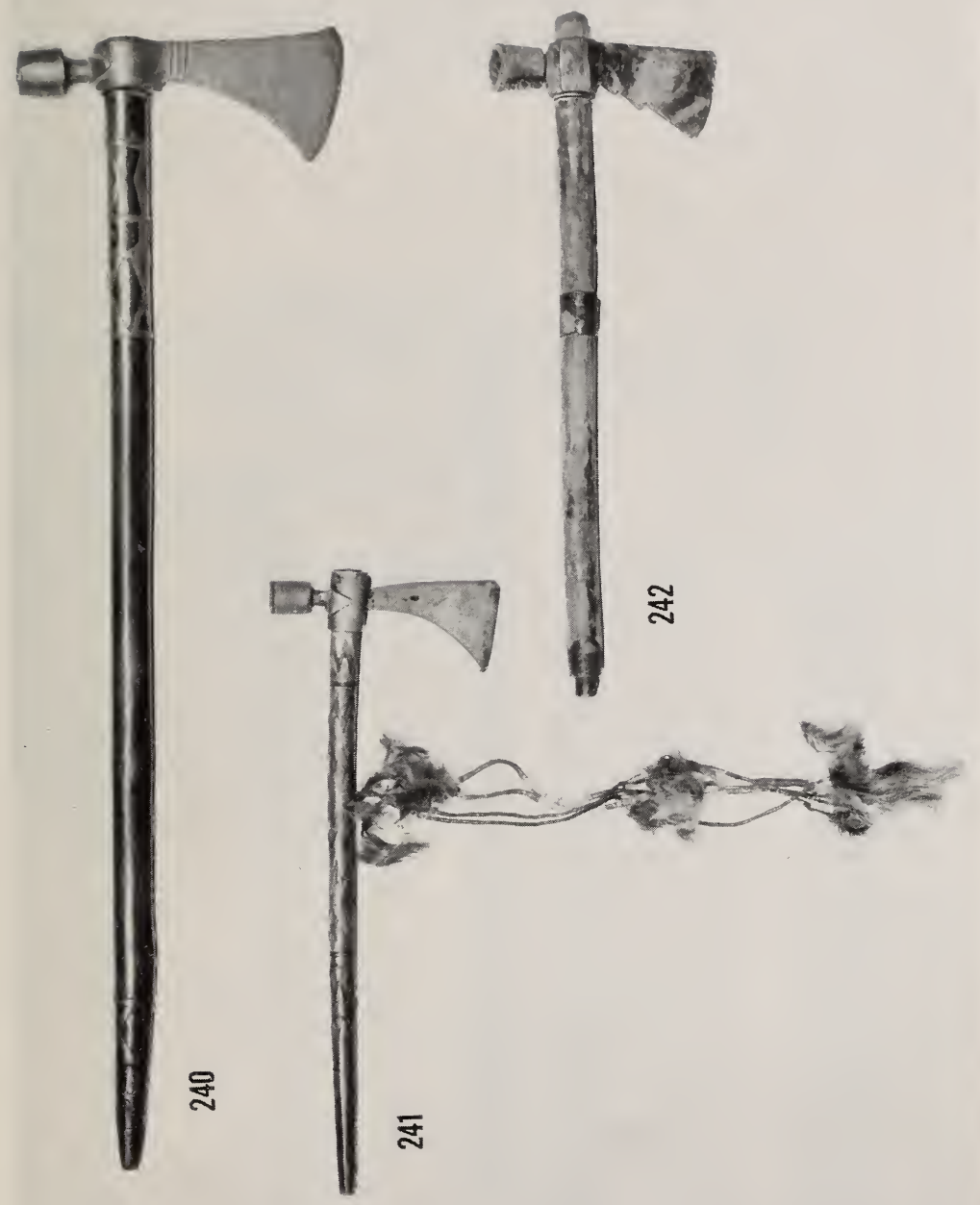



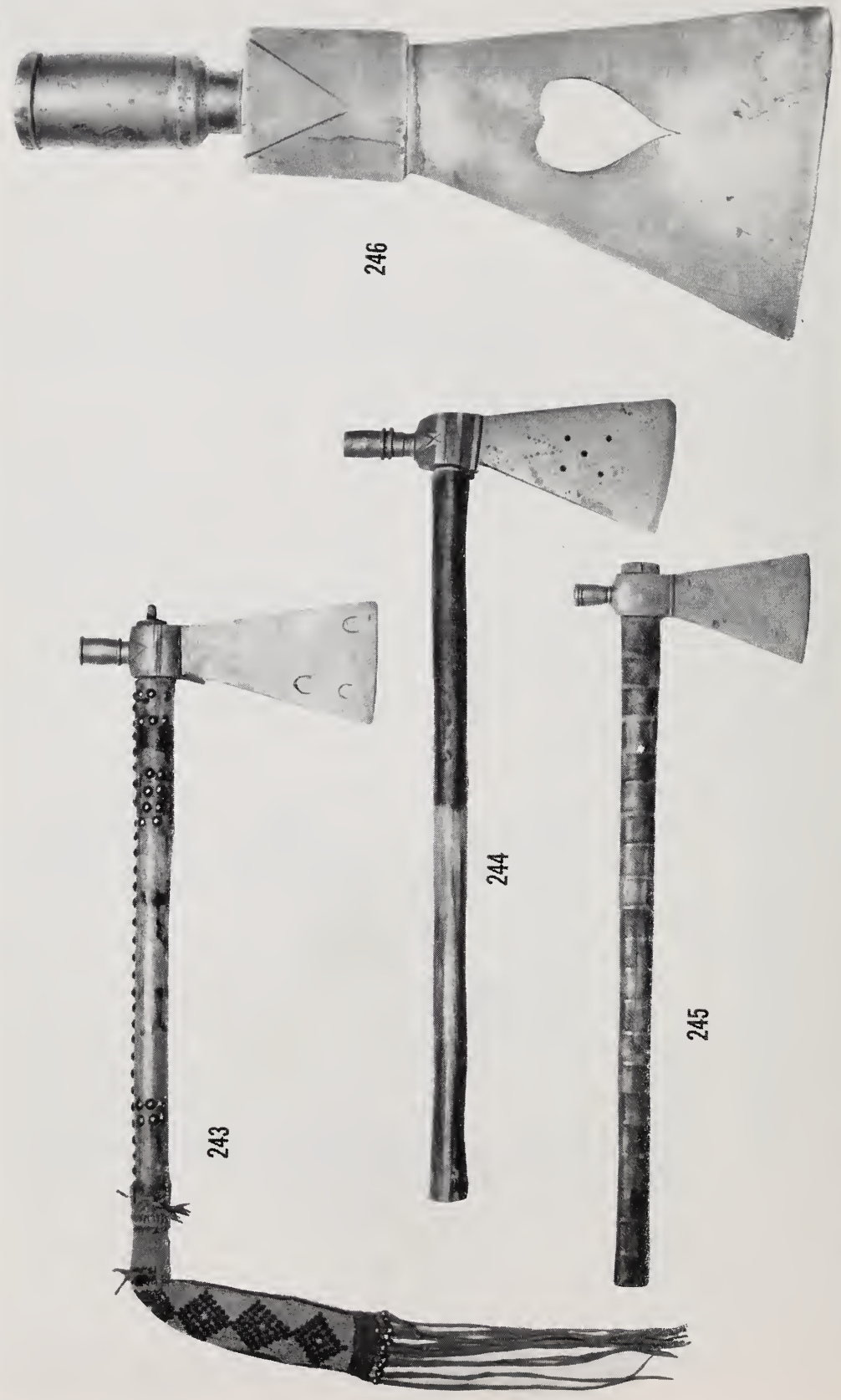

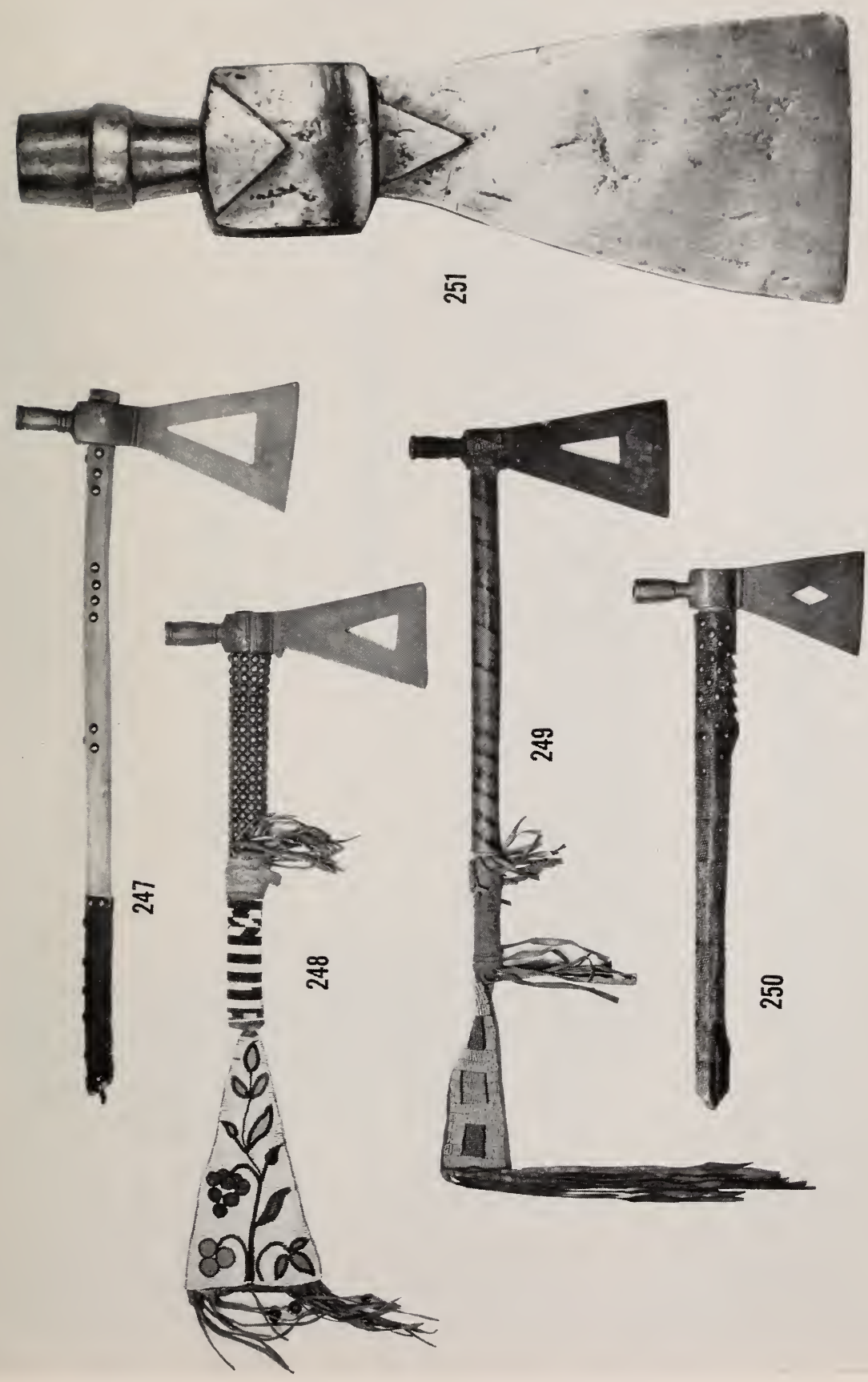


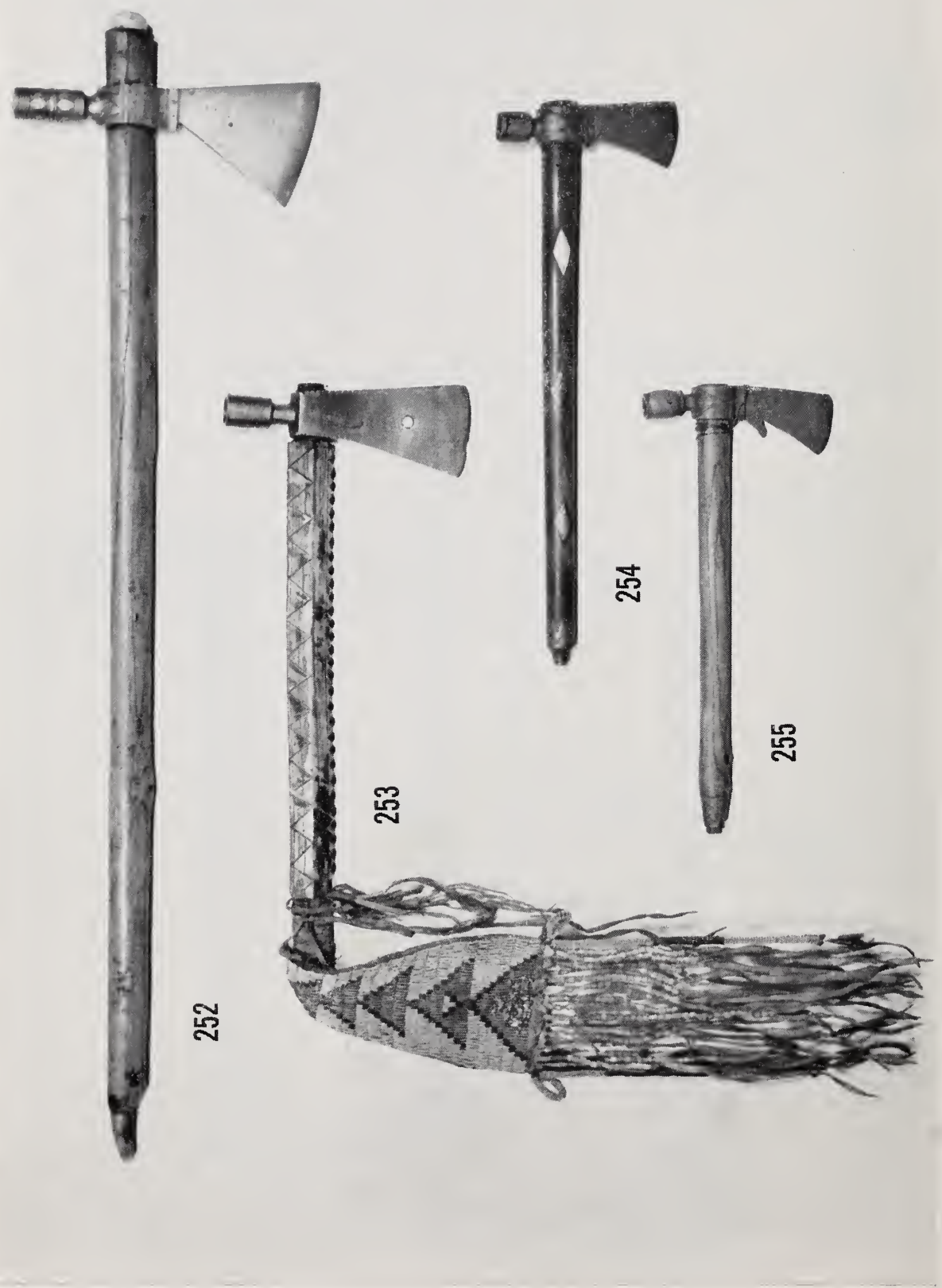




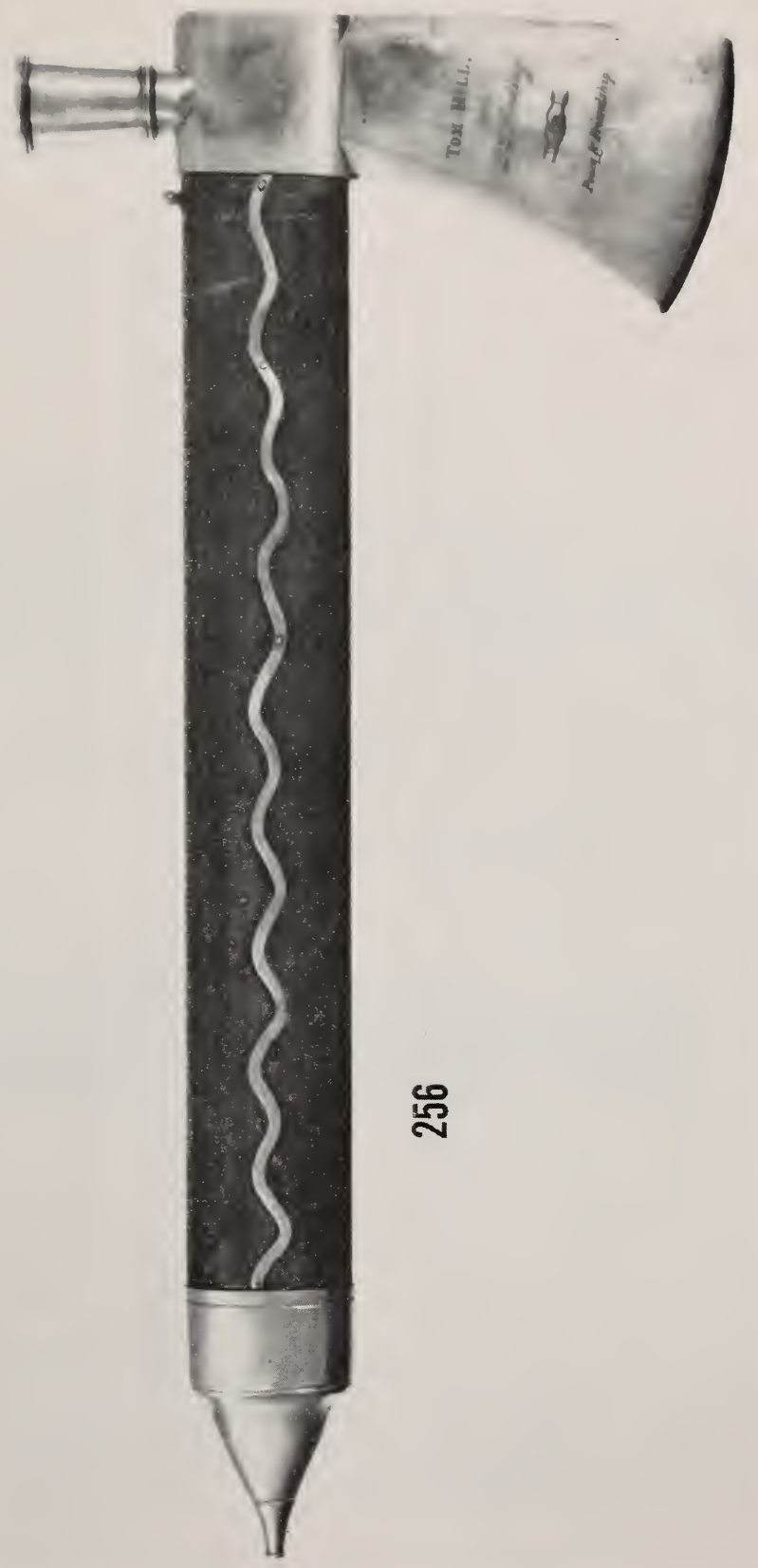



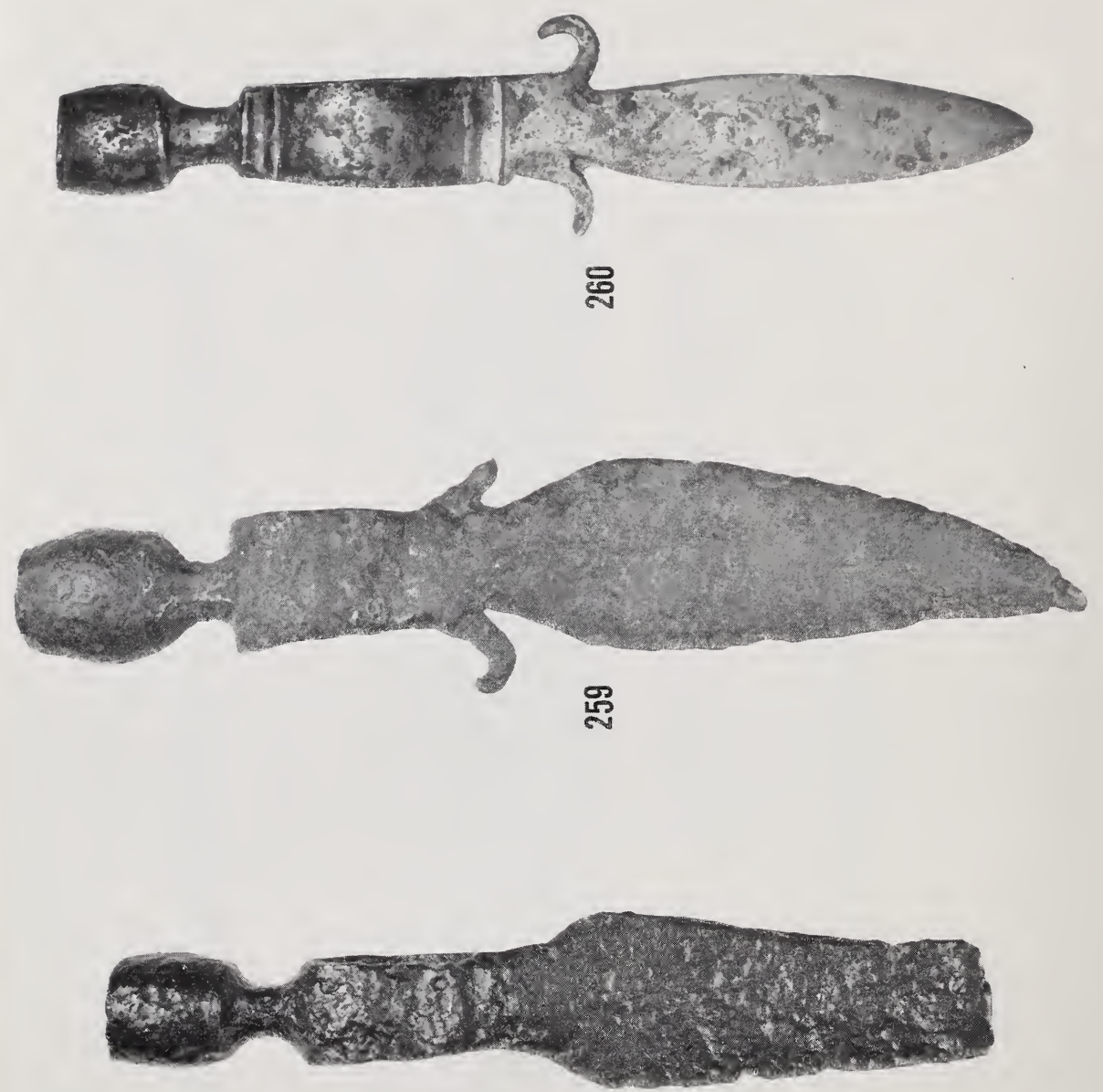

品

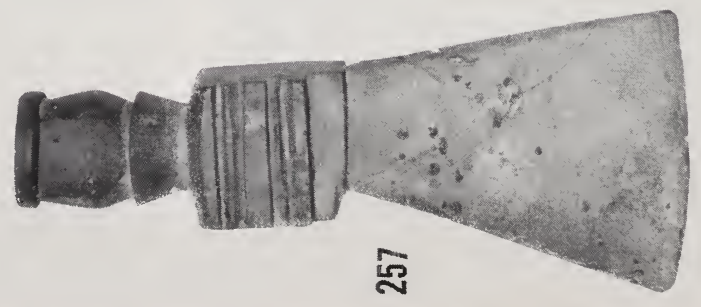




$$
T T
$$




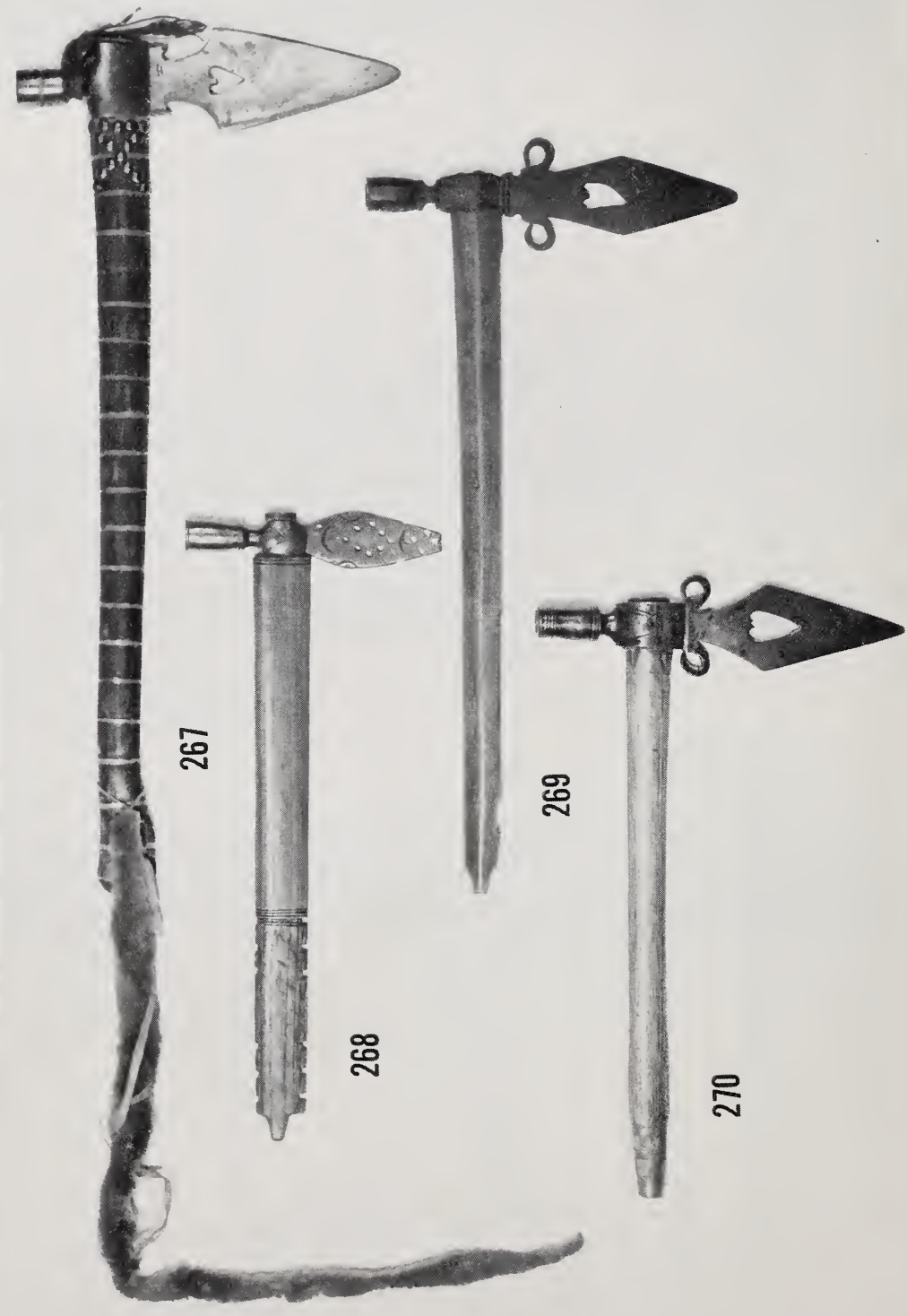



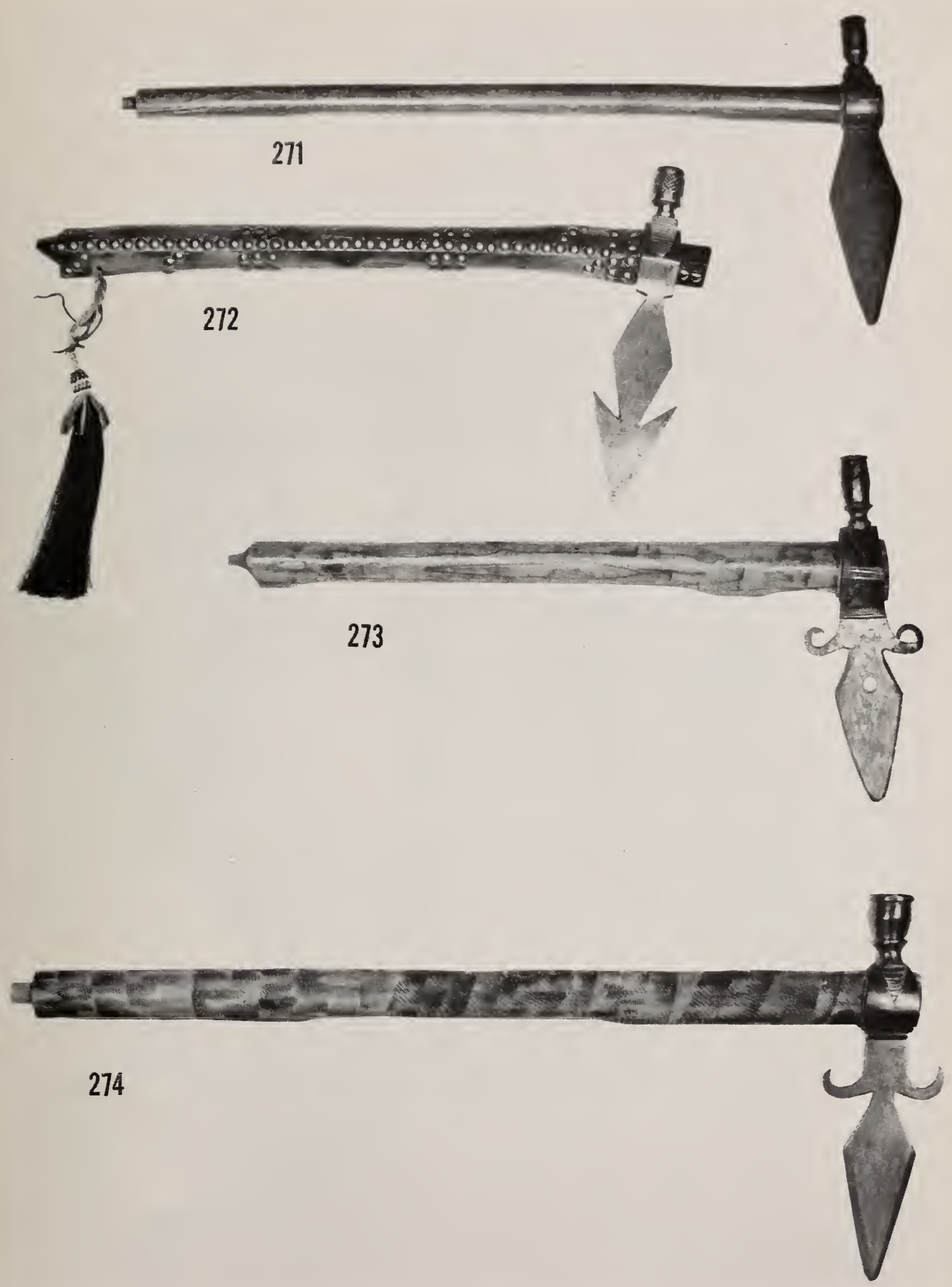


$$
\sqrt{[E}
$$




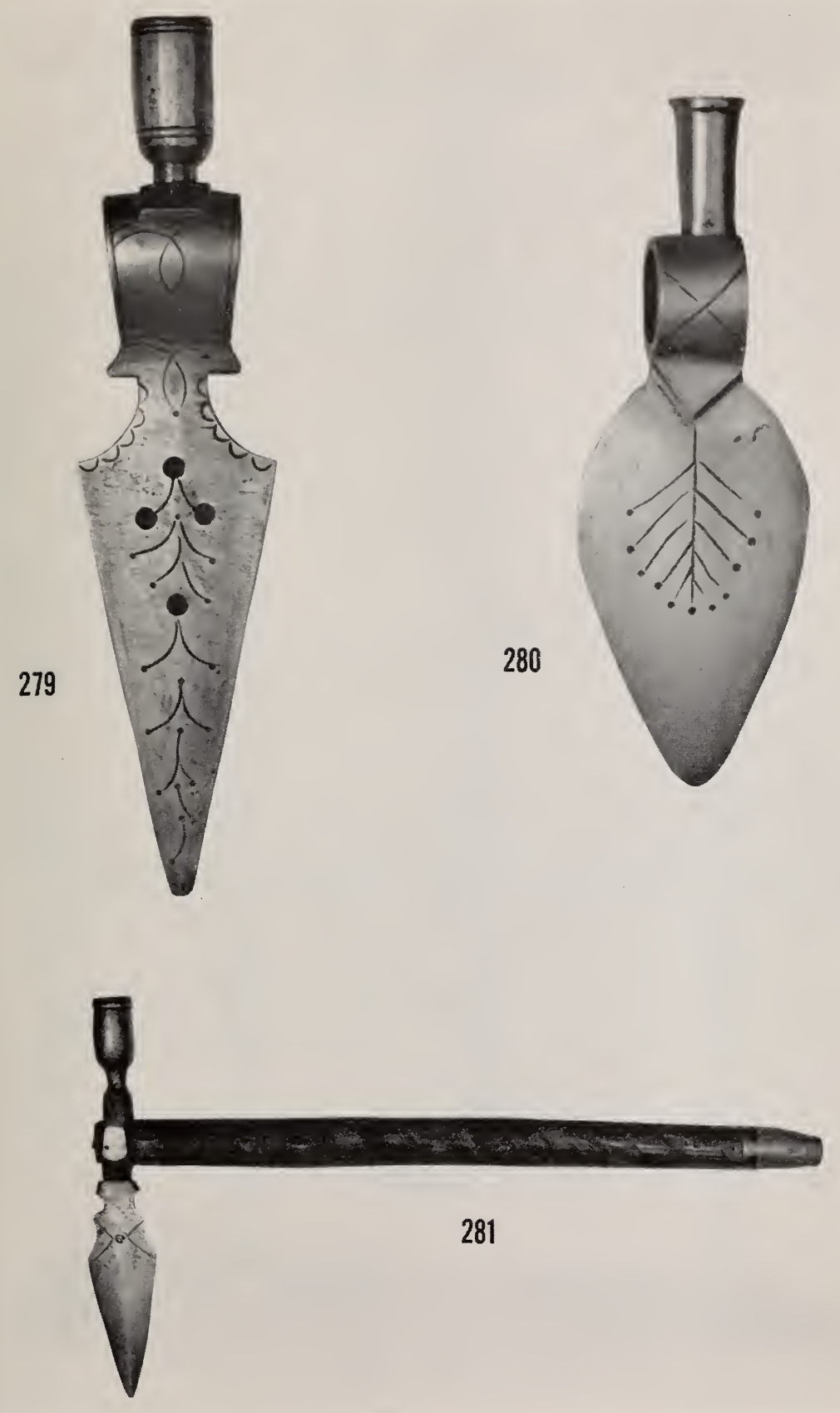




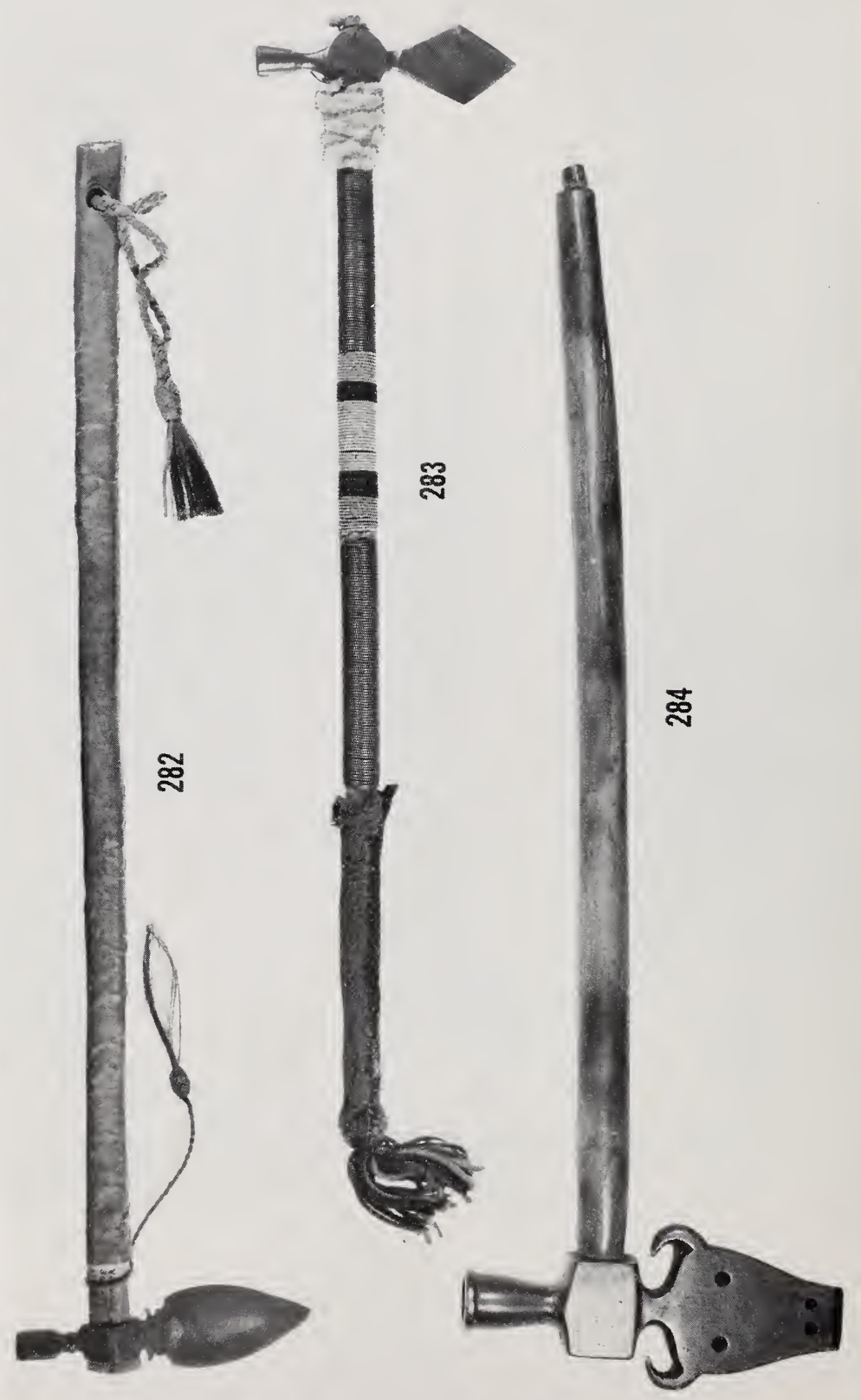



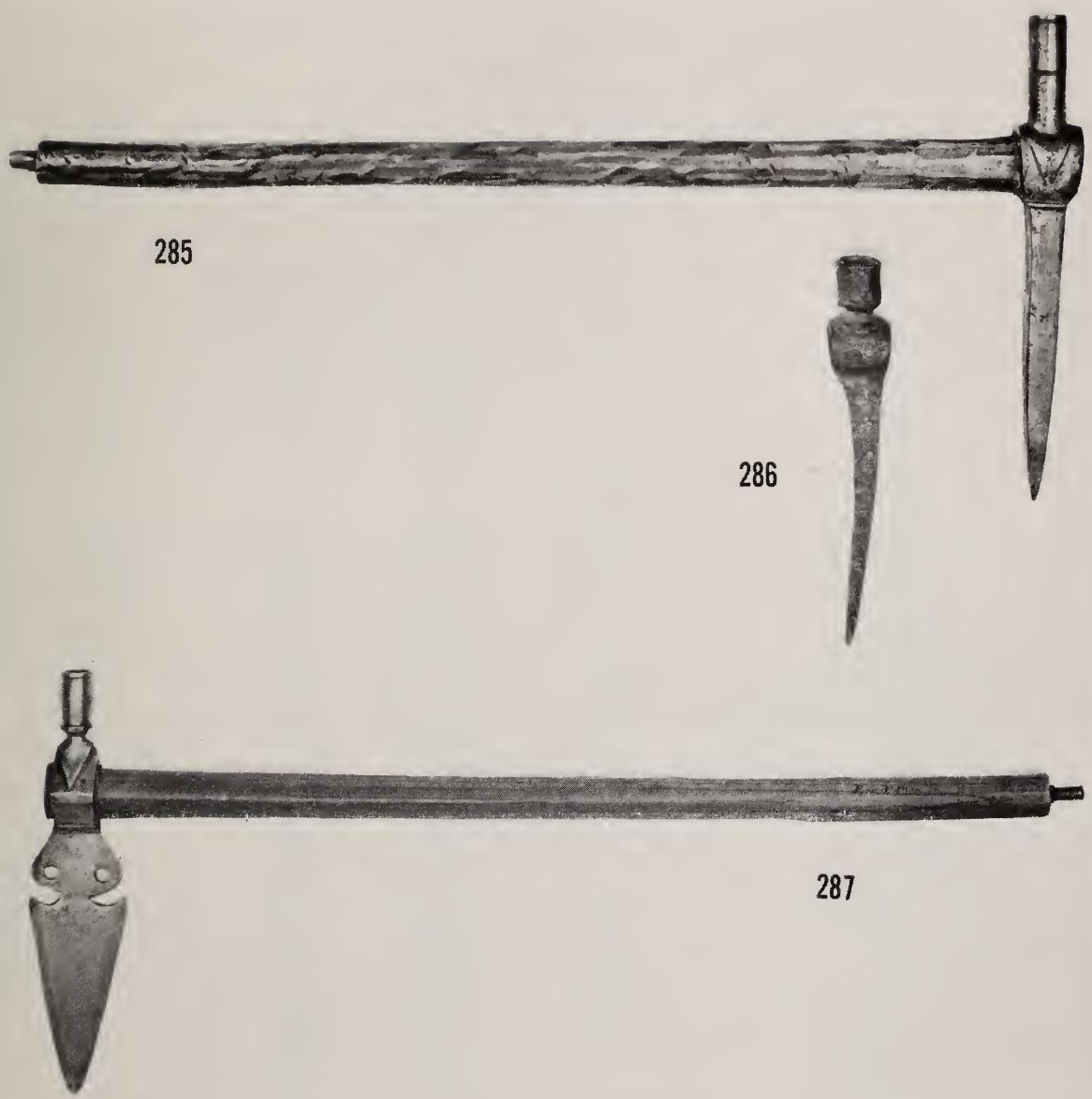


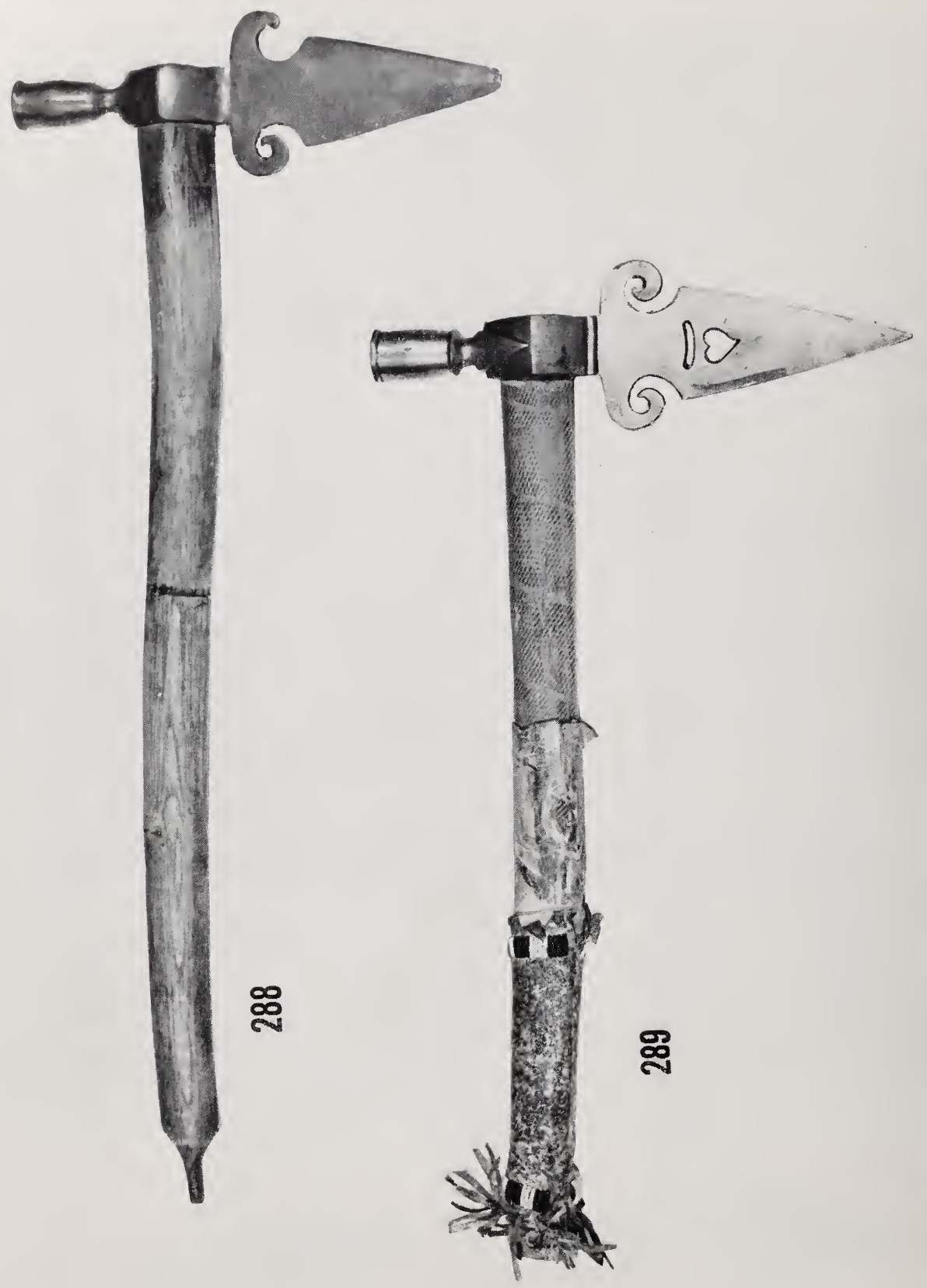




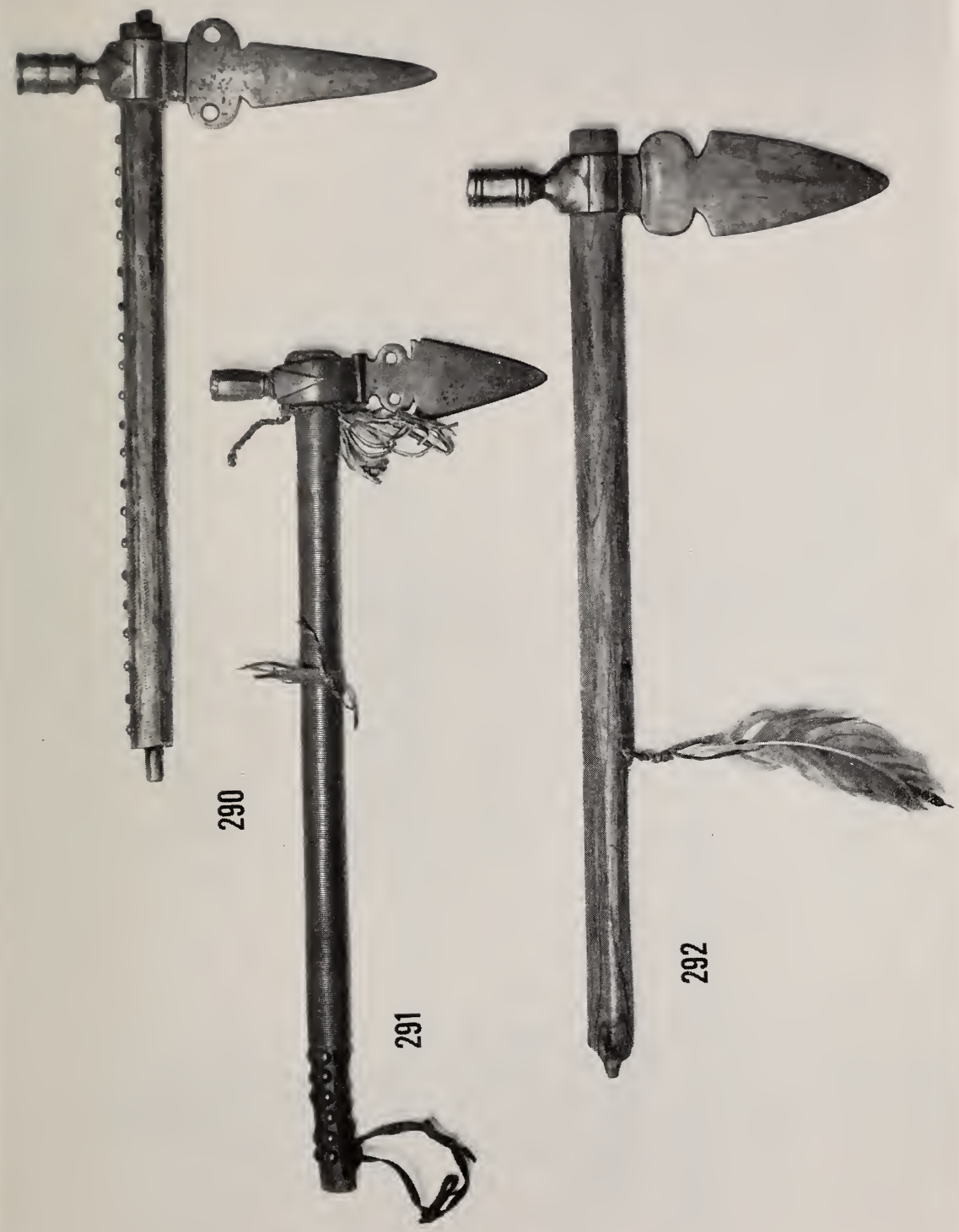




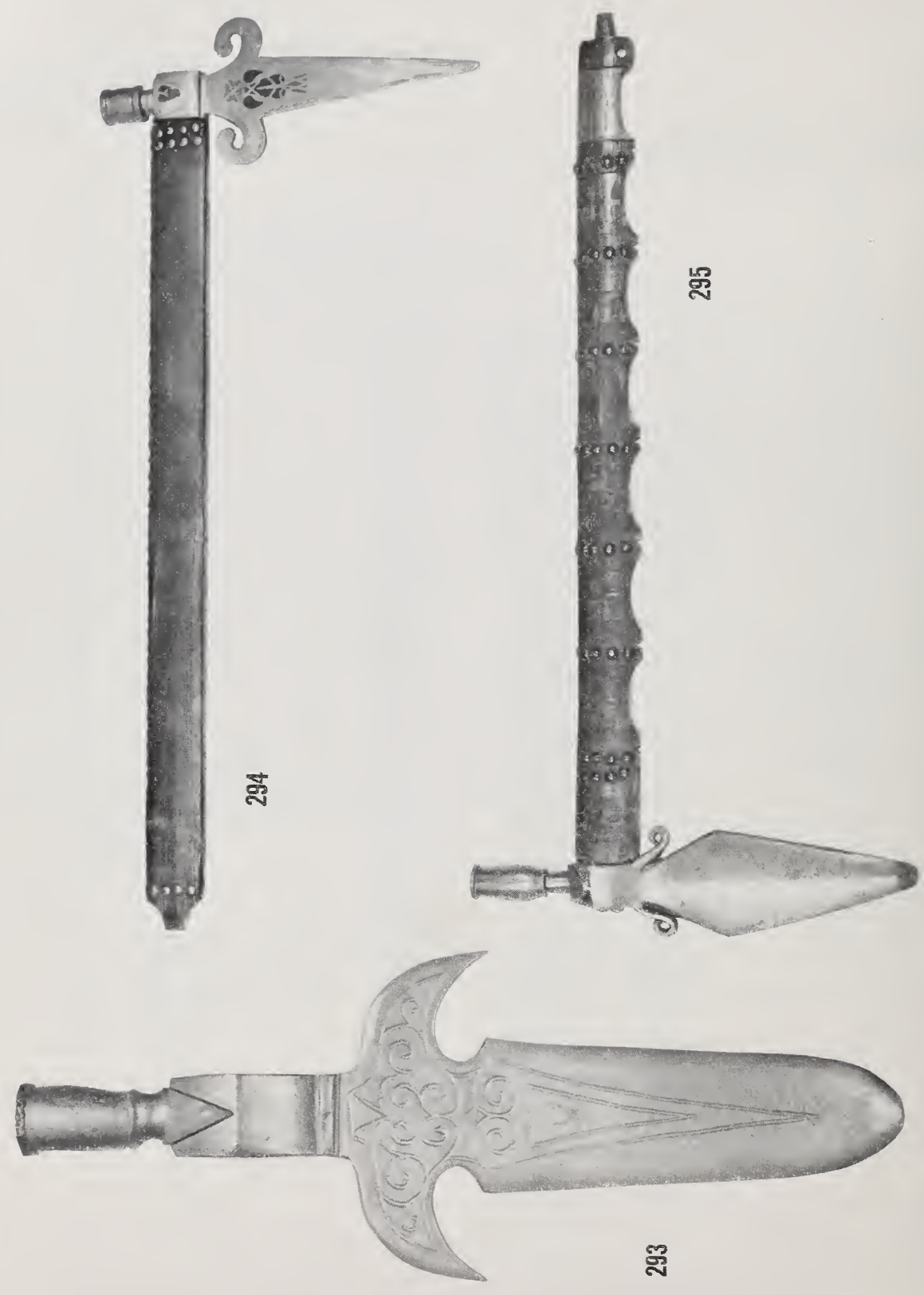



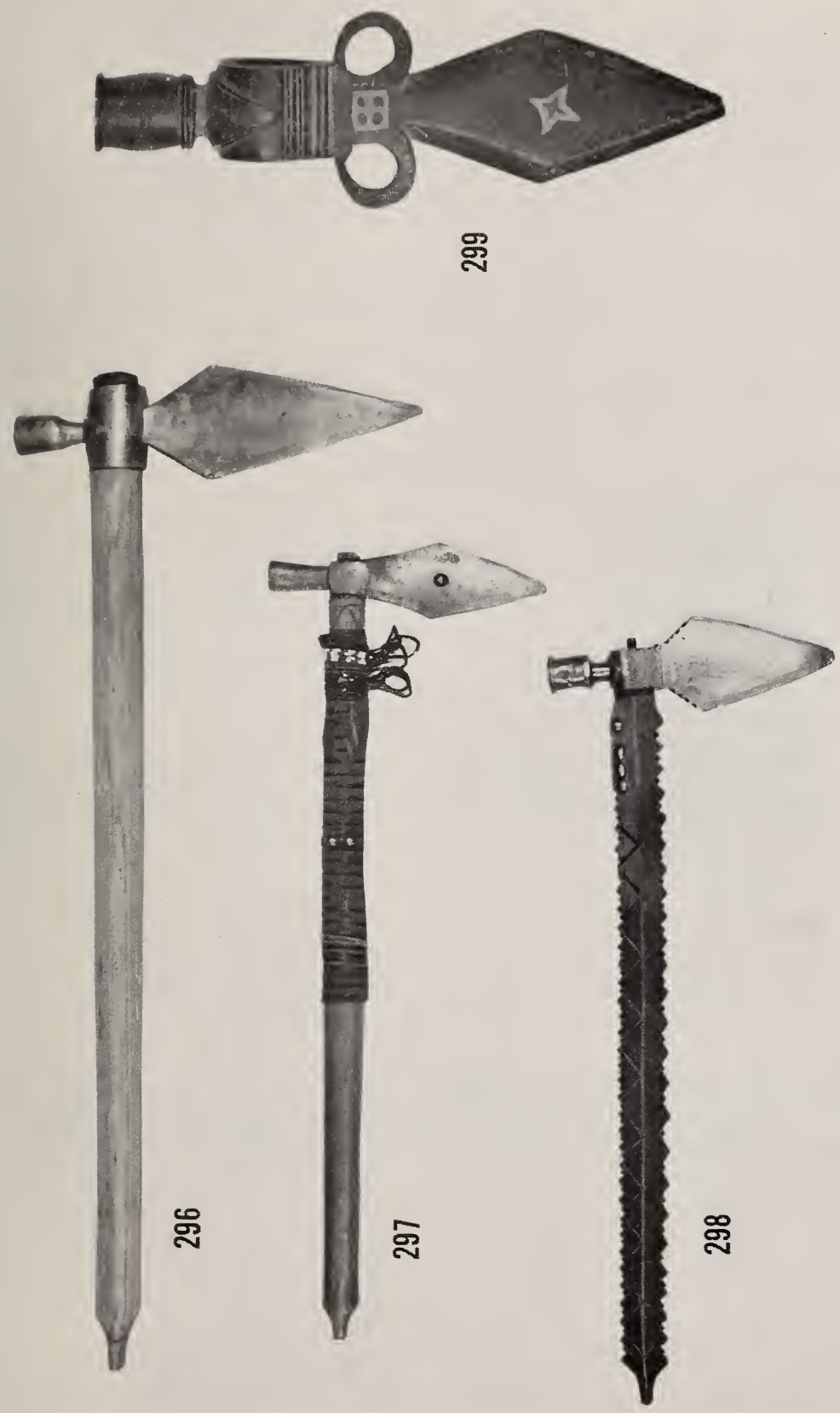

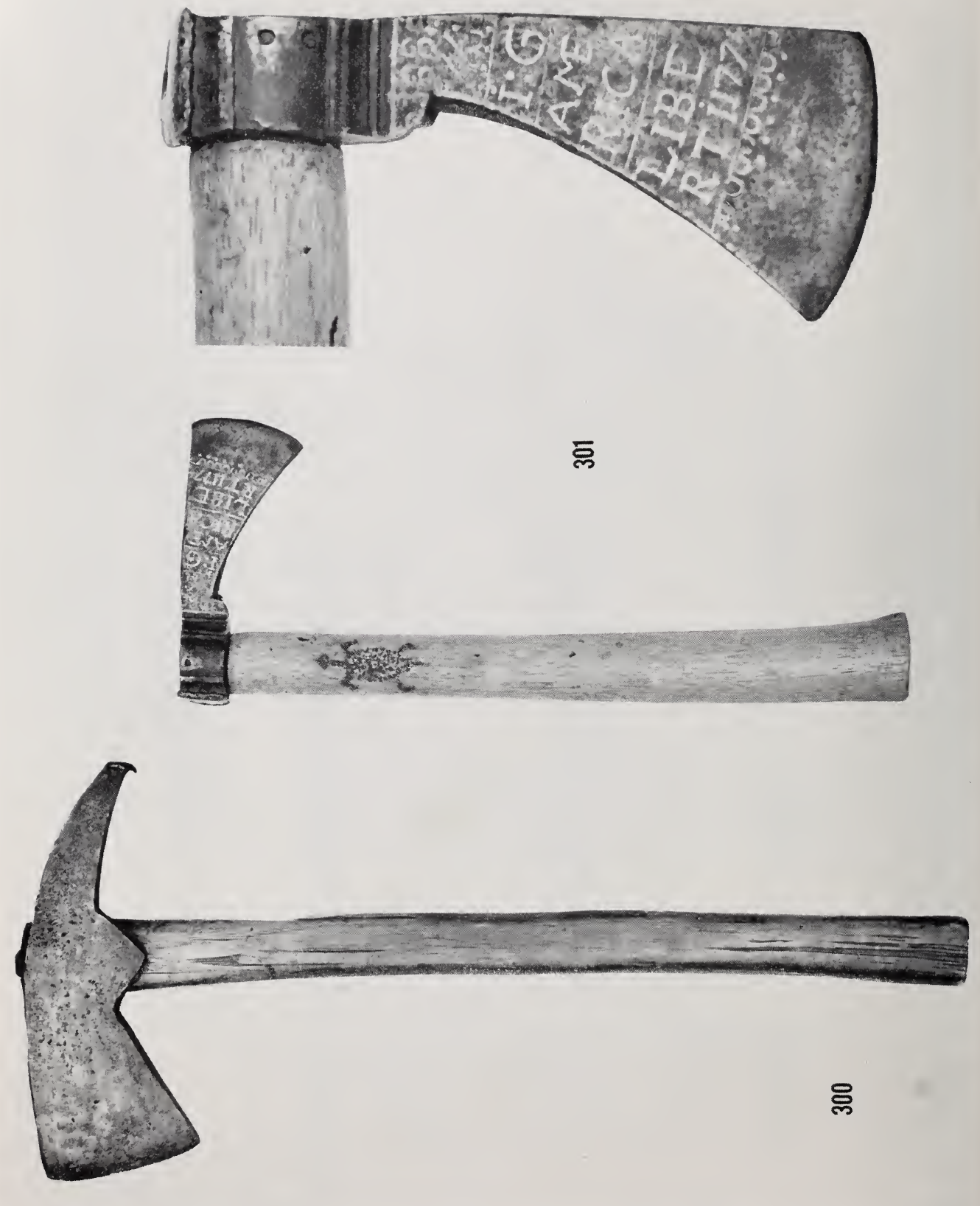

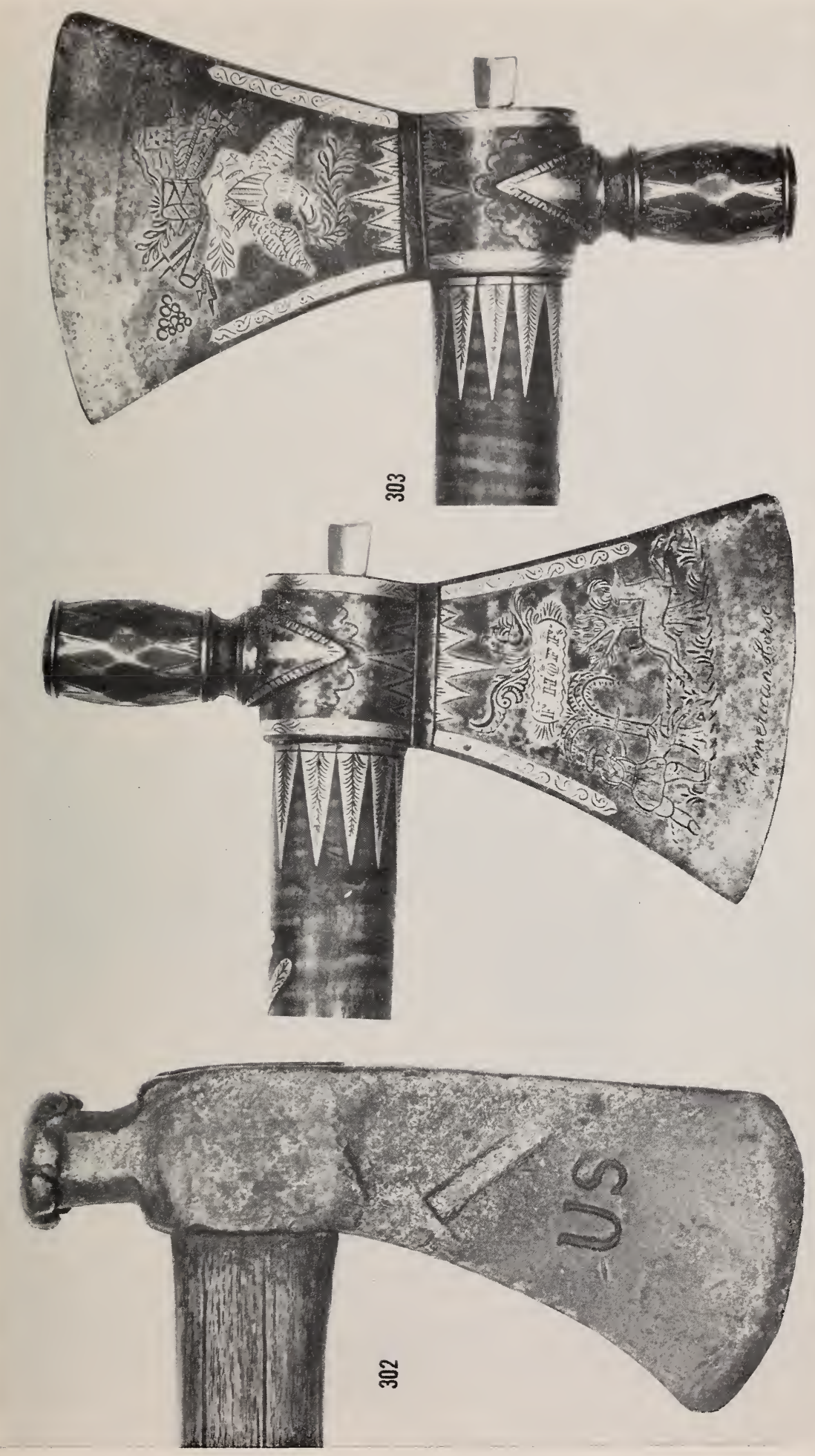

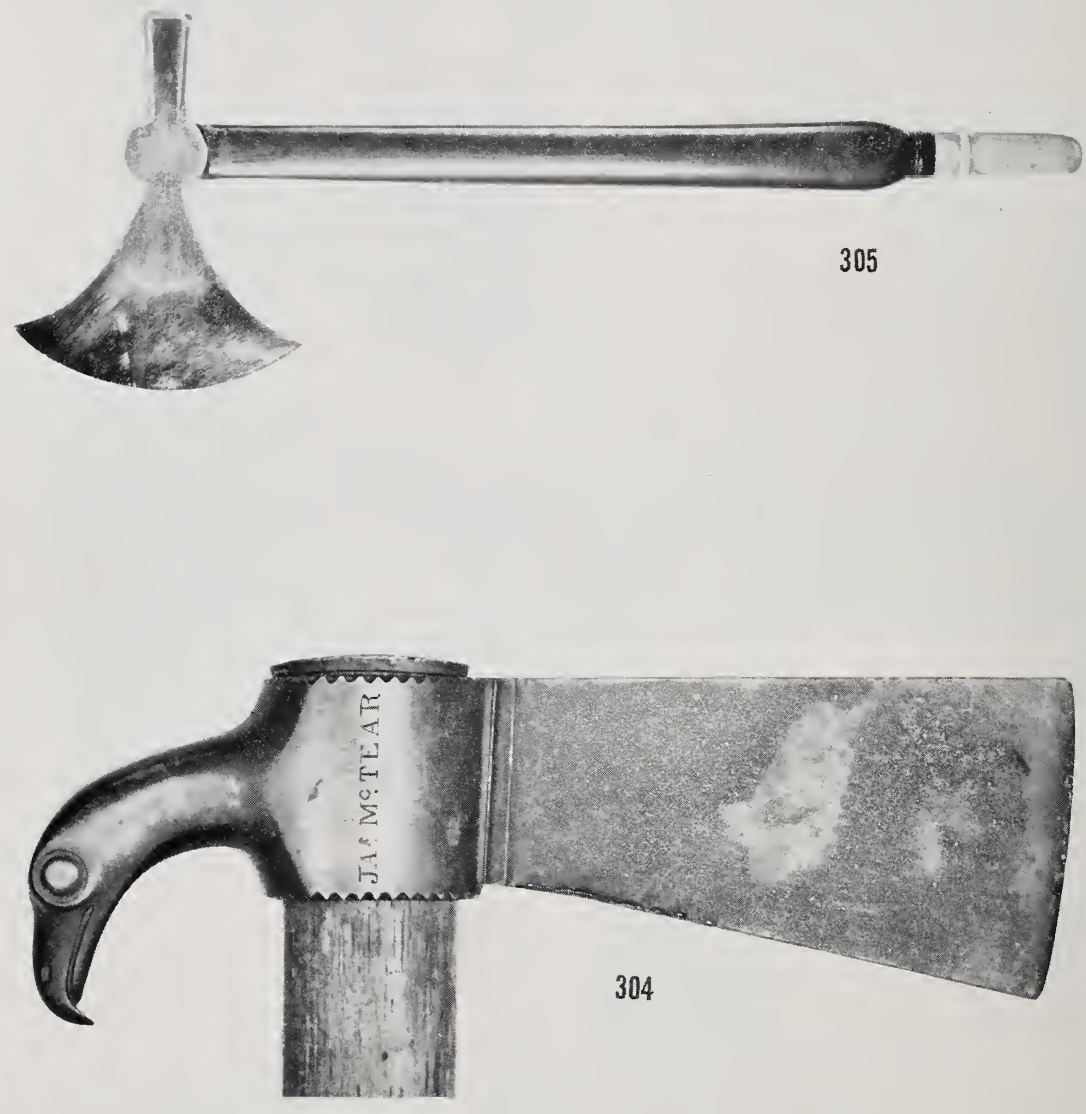

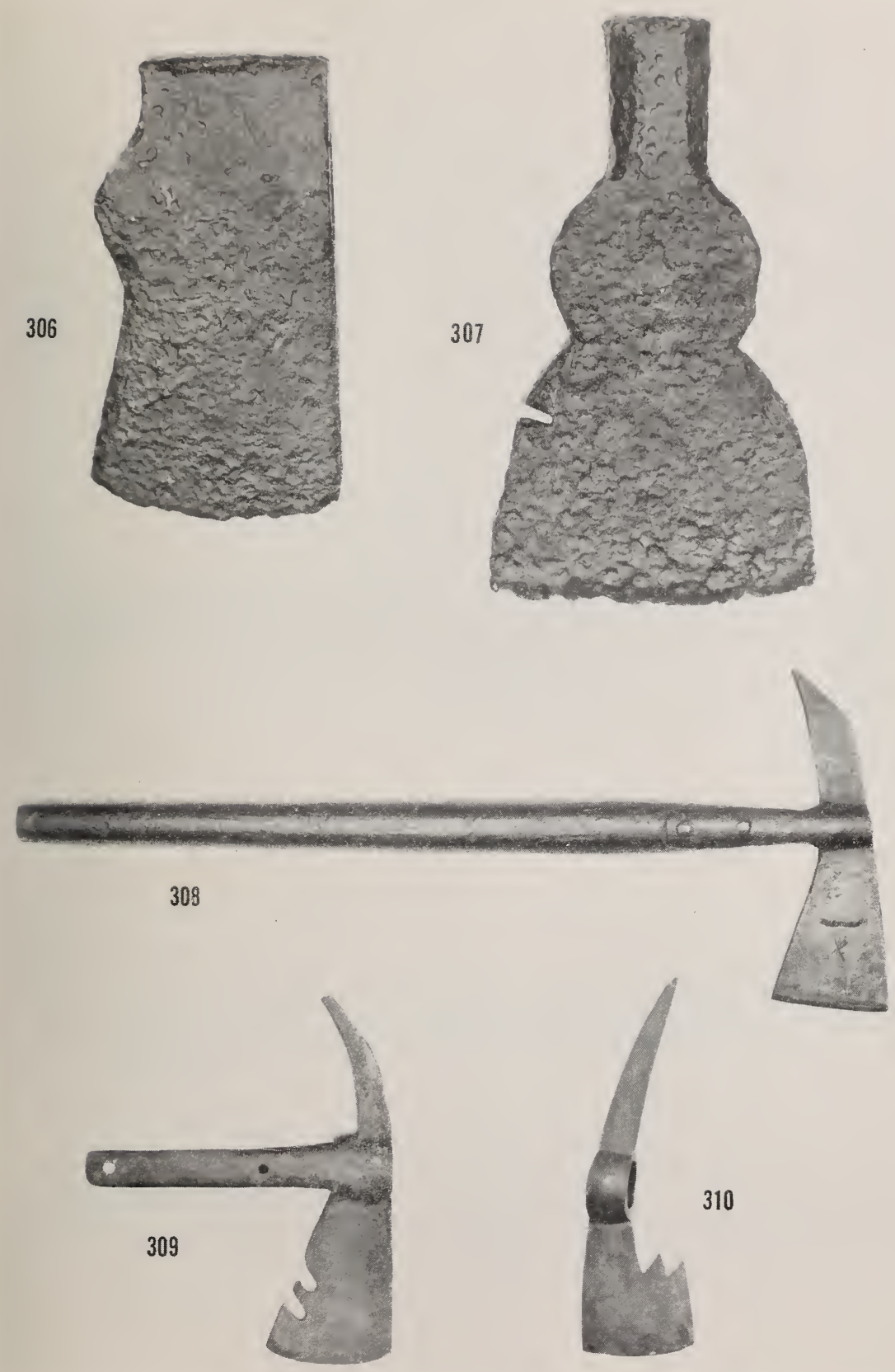

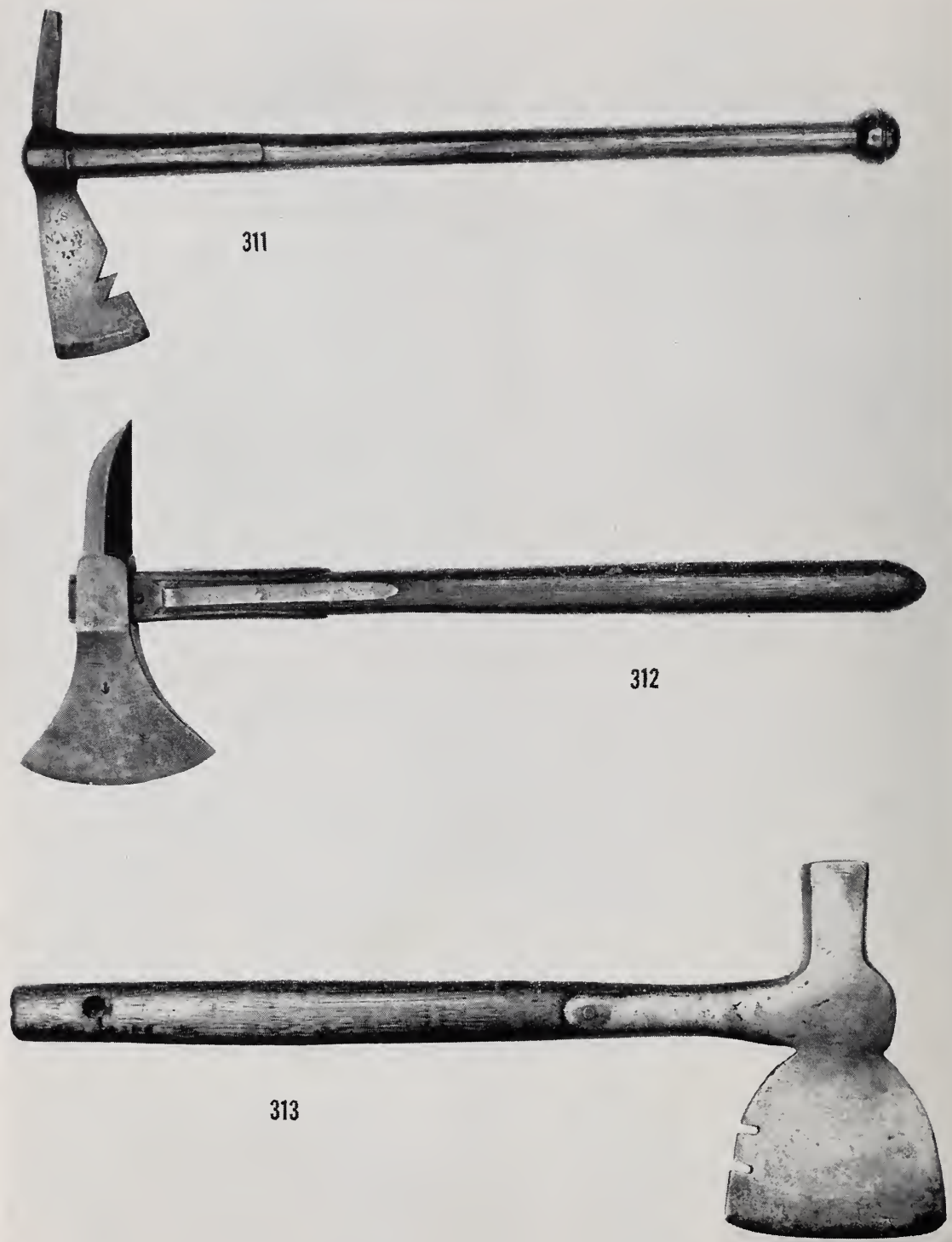


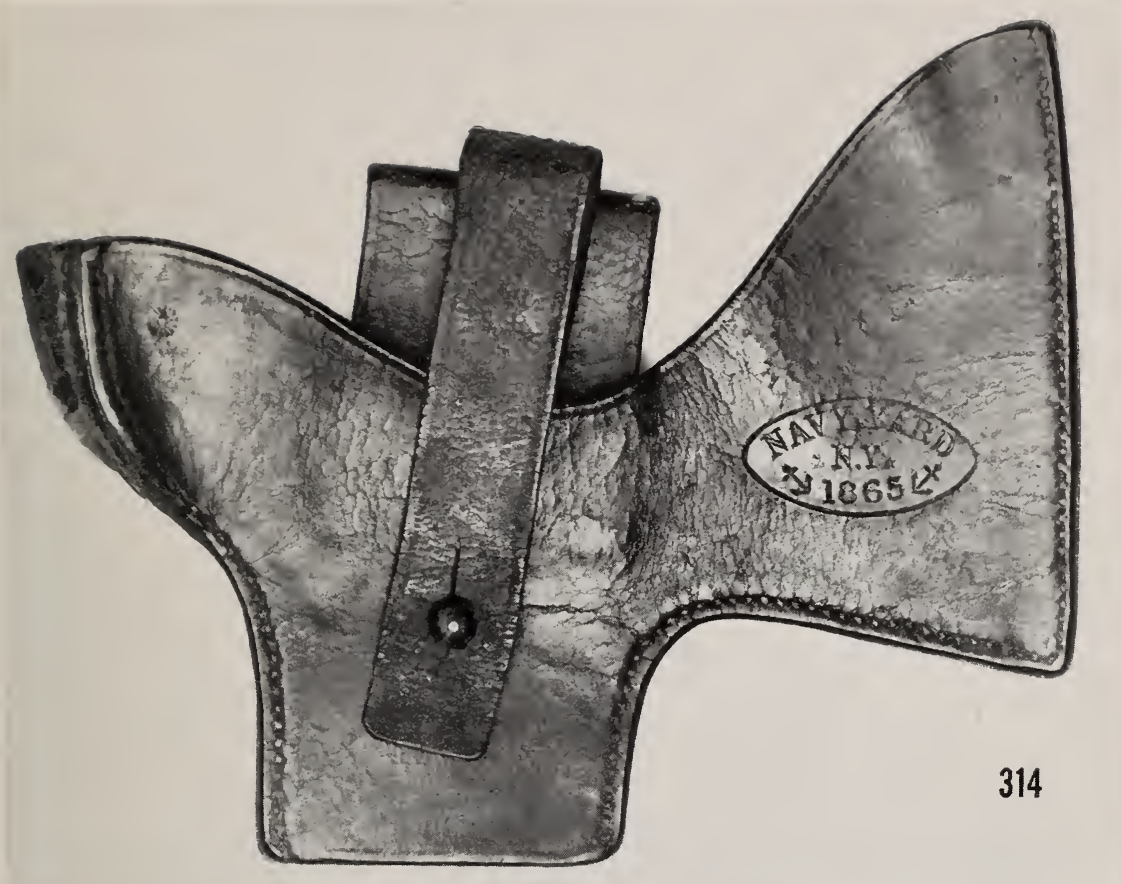




